\title{
Psychologische kenmerken van hartinfarktpatiënten : een medisch-psychologische studie
}

Citation for published version (APA):

van Dijl, H. (1981). Psychologische kenmerken van hartinfarktpatiënten : een medisch-psychologische studie. [Doctoral Thesis, Maastricht University]. Rijksuniversiteit Limburg. https://doi.org/10.26481/dis.19810403hd

Document status and date:

Published: 01/01/1981

DOI:

10.26481/dis.19810403hd

Document Version:

Publisher's PDF, also known as Version of record

\section{Please check the document version of this publication:}

- A submitted manuscript is the version of the article upon submission and before peer-review. There can be important differences between the submitted version and the official published version of record.

People interested in the research are advised to contact the author for the final version of the publication, or visit the DOI to the publisher's website.

- The final author version and the galley proof are versions of the publication after peer review.

- The final published version features the final layout of the paper including the volume, issue and page numbers.

Link to publication

\footnotetext{
General rights rights.

- You may freely distribute the URL identifying the publication in the public portal. please follow below link for the End User Agreement:

www.umlib.nl/taverne-license

Take down policy

If you believe that this document breaches copyright please contact us at:

repository@maastrichtuniversity.nl

providing details and we will investigate your claim.
}

Copyright and moral rights for the publications made accessible in the public portal are retained by the authors and/or other copyright owners and it is a condition of accessing publications that users recognise and abide by the legal requirements associated with these

- Users may download and print one copy of any publication from the public portal for the purpose of private study or research.

- You may not further distribute the material or use it for any profit-making activity or commercial gain

If the publication is distributed under the terms of Article $25 \mathrm{fa}$ of the Dutch Copyright Act, indicated by the "Taverne" license above, 
PSYCHOLOGISCHE KENMERKEN VAN HARTINFARKTPATIENTEN Een medisch-psychologische studie.

(with a summary in English)

PROEFSCHRIFT

ter verkrijging van de graad van doctor in de geneeskunde aan de Rijksuniversiteit Limburg te Maastricht op gezag van de Rector Magnificus Dr. W.H.F.W. Wijnen, hoogleraar in de faculteit der geneeskunde, volgens besluit van het college der Dekanen in het openbaar te verdedigen op vrijdag 3 april 1981 des namiddags om 4 uur precies, in de aula van de universiteit.

\author{
door \\ HANS VAN DIJL \\ geboren te Amsterdam
}


Aan mijn zoon Paul Alexander; gewoon omdat je er bent. 


\section{VOORWOORD}

\section{LIJST VAN AFKORTINGEN}

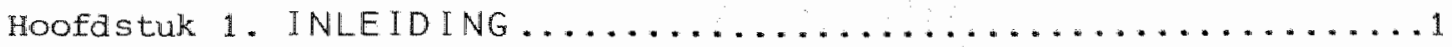

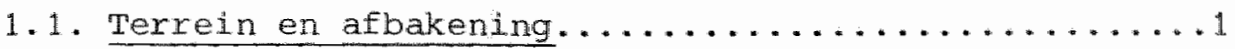

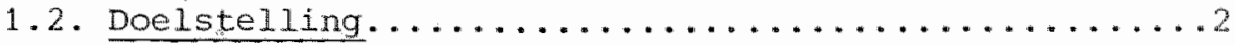

1.3. Keuze van een experimentele medisch-diagnostisch bepaalde patiëntengroep en van kontrolegroepen.......3

Hoofdstuk 2. HET ONDERZOEKSINSTRUMENT $\ldots \ldots \ldots \ldots \ldots \ldots \ldots \ldots$

2.1. Het ontstaan van de Beoordelen- van Uitspraken-

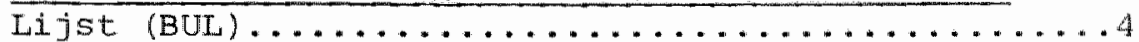

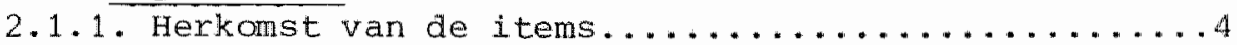

2.2. De Basisgroep "gezonden".................

2.2 .1 . Kriteria voor "gezond"..................

2.2.2. Herkomst van de "gezonde" proefpersonen uit de

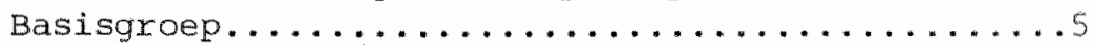

2.3. Statistische bewerkingen van de BUL............

2.3.1. Indeling in leeftijas-en opleidingsk lassen......5

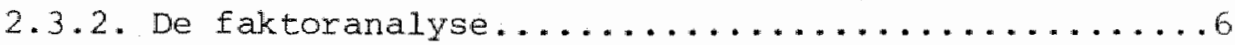

2.3.3. Het benoemen van de Eaktoren.................

2.3.4. Betrouwbaarheid van de BUL-faktoren........... 14

2.3.5. De waarde van BUL-Faktor IV.............. 14

Hoofdstuk 3. AGRESSIVITEIT BIJ PATIENTEN MET EEN CORONAIRE HARTZIEKTE, EEN LITERATUUR STUDIE ...........

3.1. Inleidende opmerkingen....................

3.2. Agressiviteit bij hartpatiënten, bezien vanuit de psychosomatische literatuur................16

3.2.1. Bevindingen gebaseerd op interview, blografisch anamnestische- en projektietestgegevens........16

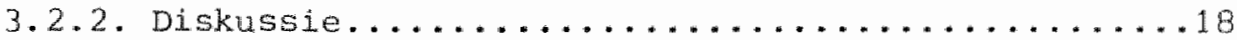

3.2.3. Bevindingen gebaseerd op indelingen in door de onderzoeker(s) zelf min of meer omschreven

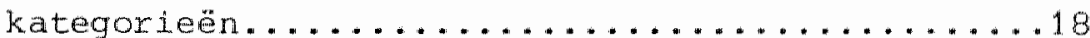

3.2.4. Diskussie............................. 19

3.2.5. Bevindingen gebaseerd op vergelijkend psychologisch testgedrag, met statistische bewerkingen.19

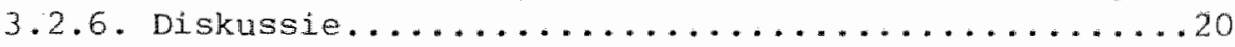


HOOEdStuK 4. DEPRESSIVITEIT BIJ PATIENTEN MET EEN CORONAIRE HARTZIEKTE, EEN LITERATUURSTUDIE ..............

4.1. Depressiviteit bij hartpatienten, bezien vanuit

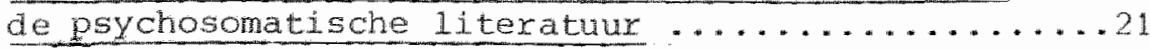

4.1.1. Bevindingen gebaseerd op interview-, biografisch anamnestische- en projektietestgegevens........21

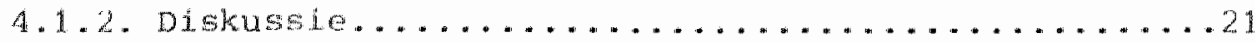

4.1.3. Bevindingen gebaseerd op indelingen in door de ondexzoekex (s) zelf min of meer omschreven

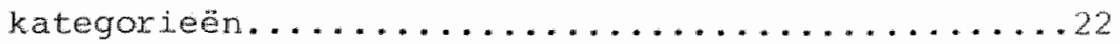

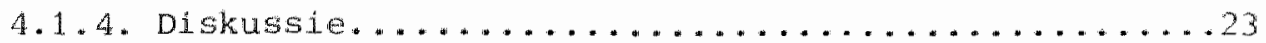

4.1.5. Bevindingen gebaseerd op vergelijkend psychologisch testgedrag, met statistische bewerkingen...23

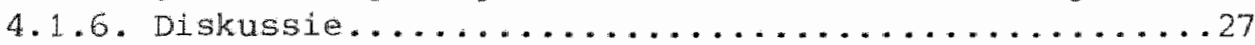

Hoofdstuk 5. AKTIVITEITSGRAAD EN WERKINSTELLING BIU PATIENTEN MET EEN CORONAIRE HARTZIEKTE, EEN

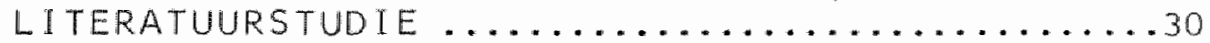

5.1. Attituden ten aanzien van werken en aktiviteit bij hartpatiënten, bezien vamuit de psychosomatische

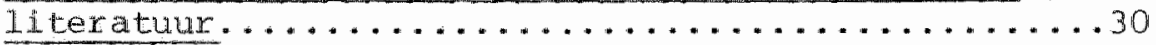

5.1 .1$. Inleding . . . . . . . . . . . . . . . . . . . . . . . . . . .

5.1.2. Bevindingen gebaseerd op interview-, biografisch

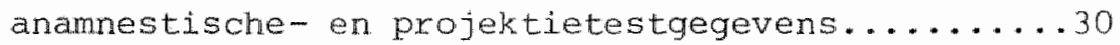

5.1 .3 . Diskussie.....................................

5.1.4. Bevindingen gebaseerd op indelingen in door de onderzoeker (s) zelf min of meer omschreven

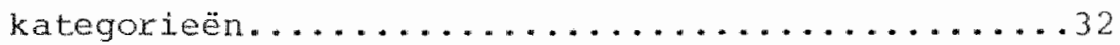

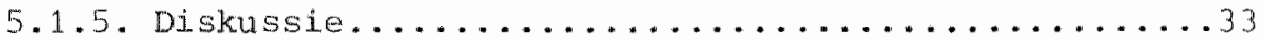

5.1.6. Bevindingen gebaseerd op vergelijkend psychologisch testgedrag, met statistische bewerkingen....34

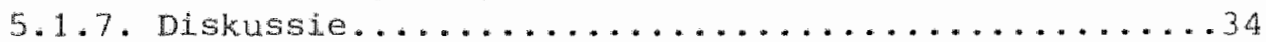

Hoofastuk 6. SOCIABILITEIT BIJ PATIENTEN MET EEN CORONAIRE HARTZIEKTE, EEN LITERATUURSTUDIE .............

6.1. Sociabiliteit bij hartpatiénten, bezien vanuit de

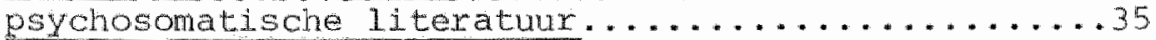

6.1.1. Bevindingen gebaseerd op interview-, biografisch anamnestische- en projektietestgegevens...........35

$6.1 .2 . \mathbb{D i s k u s s i e \ldots \ldots \ldots \ldots \ldots \ldots \ldots \ldots \ldots \ldots \ldots \ldots \ldots \ldots \ldots \ldots \ldots \ldots \ldots \ldots \ldots}$

6.1.3. Bevindingen gebaseerd op indelingen in door de onderzoekex (s) zelf min of meer omschreven

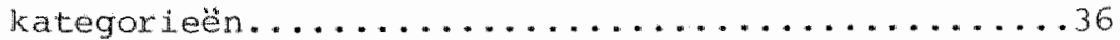

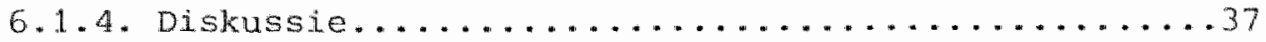


6.1.5. Bevindingen gebaseerd op vergel1jkend psychologisch testgedrag, met statistische bewerkingen... 36

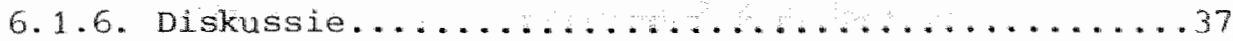

Hoofdstuk 7. BEROEPSVERANTWOORDELIJKHEID BIJ PATIENTEN MET EEN CORONAIRE HARTZIEKTE, EEN LITERATUUR-

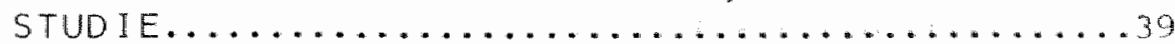

7.1. Beroepsverantwoordelijkheid bij hartpatienten. bezien vanuit de psychosomatische literatuur.......39

7.1.1. Bevindingen gebaseerd op interview- biografisch anamnestische- en projektietestgegevens....................

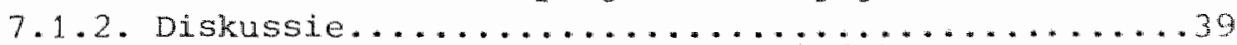

7.1.3. Bevindingen gebaseerd op indelingen in door de onderzoeker(s) zelf min of meer omsohreven

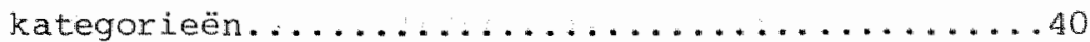

7.1 .4$. Diskussie............................ . . . . . . .

7.1 .5 . Bevindingen gebaseerd op vergelijkend psychologisch testgedrag, met statistische bewerkingen...41

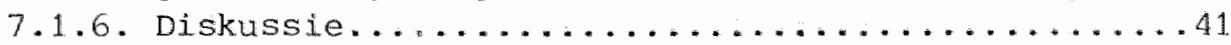

Hoofdstuk 8. OPERAT IONALISERING VAN KLINISCHE GEGEVENS

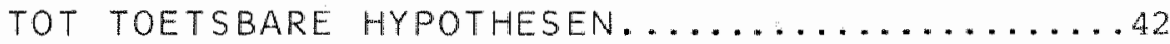

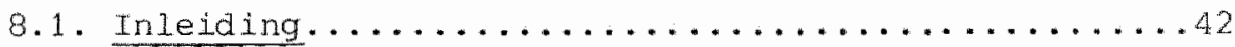

8.2. Afleiding van toetsbare hypothesen..............43

8.2.1. Hypothese betreffende agressiviteit bij

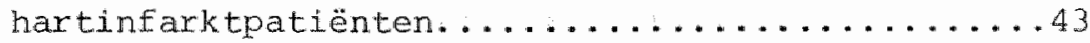

8.2.2. Hypothese betreffende depressiviteit blj hartinfarktpatiënten.......................... 43

8.2.3. Hypothesen betreffende aktiviteit en wexkinstelling bij hartinfarktpatienten............44

8.2.4. Hypothesen betreffende sociabiliteit bij

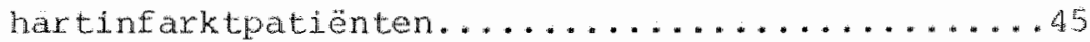

8.2.5. Hypothesen betreffende beroepsverantwoordelifkheid

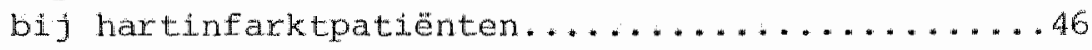

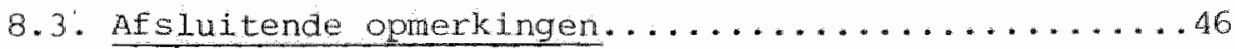

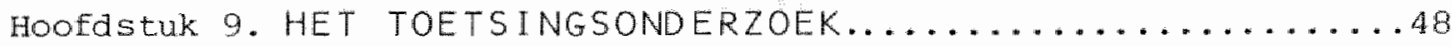

9.1. Samenstelling van de experimentele- en kontrolegroepen en herkomst van de proefpersonen.........48

9.1.1. De experimentele groep van hartinfarktpatienter. .48

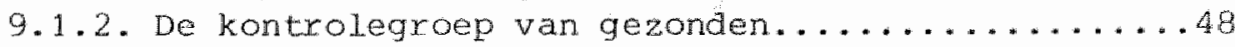

9.1.3. De kontrolegroep van astmapatientten..........48 
9.2. Voorspellingen............................ 51

9.2.1. De onderzoeksvariabelen..................... 51

9.2.2. Konkrete voorspellingen ten aanzien van de onder-

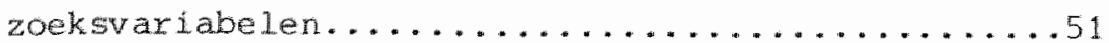

9.3. Toetsingen en resultaten $\ldots \ldots \ldots \ldots \ldots \ldots \ldots \ldots \ldots 2$

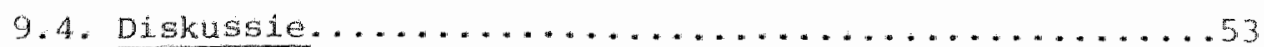

9.4.1. Gesteunde hypothesen....................53

9.4.2. Niet gesteunde hypothesen................53

9.4.3. Kritische kanttekeningen bij de resultaten......53

Hoofdstuk 10. HET EERSTE KRUISVALIDATIEONDERZOEK ........55

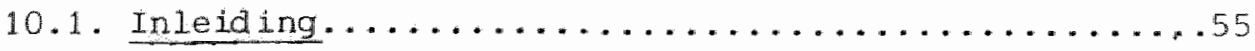

10.2. Samenstelling van de experimentele- en kontrolegroepen en herkomst van de proefpersonen.........55

10.2.1. De experimentele groep van hartinfarktpatiënten. 55 10.2.2. Kriteria voor "gezond" en de samenstelling van de kontrolegroep van gezonden............. 55

10.2.3. De kontrolegroep van astmapatienten.........58

10.3. Voorspellingen, toetsingen en resultaten........59

10.4. Diskussie............................. . . . . . . . .

10.4.1. Gesteunde hypothesen...................... 59

10.4.2. Niet gesteunde hypothesen..................59

10.4.3. Bevindingen bij een hertoetsingsonderzoek van

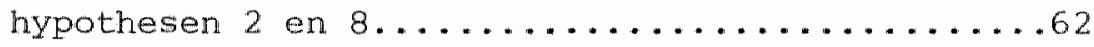

10.4.4. Kritische kanttekeningen bij de resultaten van

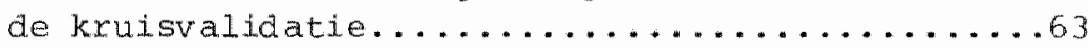

Hoofdstuk 11. HET TWEEDE KRUISVALIDATIEONDERZOEK EN EEN UITBREIDING VAN HET ONDERZOEKSTERREIN ......65

11.1 . Inleiding. . . . . . . . . . . . . . . . . . . .65

11.2. Samenstelling van de experimentele- en kontrolegroepen en hexkomst van de proefpersonen.........65

11.2.1. De experimentele groep van hartinfarktpatiënten..65 11.2.2. De kontrolegroep van "gezonde" mannen.........66 11.2.3. De kontrolegroep van mannen met medische diagnoses anders dan hartinfarkt en astma...........66

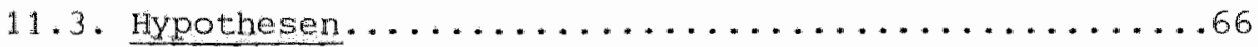
11.3.1. Hertoetsing van 4 reeds gesteunde hypothesen...66 11.3.2. Vier additionele hypothesen..............68 11.4. Voorspellingen, toetsingen en resultaten.......68 
11.5. Onderzoeksbevindingen en diskussi.e...........70

11.5.1. Bevindingen bij BuL-Faktor $I$ : Agressiviteit.....70 11.5.2. Bevindingen bij BUL-Faktor III: Aktiviteit en werken...............................

11.5.3. Bevindingen bij BuL-Faktor $\mathrm{V}$ : Sociabiliteit....72 11.5.4. Bevindingen bij BUL-Faktor VI: BeroepsverantwoordeIijkheid............................. . . .

11.5.5. Bevindingen bij BUL-Faktor II: Depressiviteit. . .73

11.5.6. Diskussie met konklusies................. 4

Hoofdstuk 12. A/B-TYPOLOGIE EN JENKINS ACTIVITY SURVEY

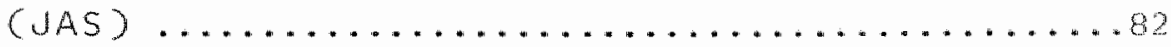

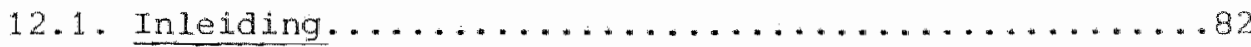

12.2. De ontwikkeling van de $A / B$-typologie..........82

12.2.1. De eerste formuleringen en onderzoekingen... . . .82

12.2.2. Definitie van het Type A-en Type B-gedrag,

tesamen met enkele verschillen op somatisch nivo.84

12.3. De Western Collaborative Group study (WCGS).... . . 85

12.3.1. Indeling van de onderzoekspopulatie in Type Aen Type B-mannen met daarbij gevonden verschilien in prevalentie van coronaire hartziektem.......85

12.3.2. Incidentie van coronaire hartziekten bij Type Aen -B-mannen, verkregen bij prospektief onderzoek........................... 88

12.3.3. Vergelijking van de prediktieve validiteit van de $A / B$-typologie met die van enkele somatische risiko-faktoren....................... 88

12.3.4. De A/B-typologie als statistisch onafhankelijke risiko-faktor........................44

12.3.5. Betrouwbarheid van het gestandaardiseerde interview............................ . . . . . . . .

12.3.6. Stabiliteit van het Type A- of -B-gedragspatroon.96 12.4. De Jenkins Activity Survey (JAS) ............ 97

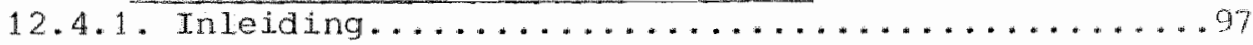

12.4.2. Herkomst wan de JAS-i.tems en de konstruktie wan

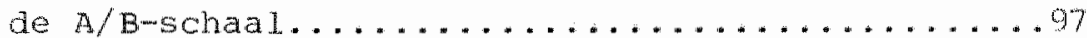

12.4.3. Faktoranalytische bevindingen bij de JAS.......99

12.4.4. Coronaixe hartziekten en JAS-resultaten bij retrospektief onderzoek.................100

12.4.5. Coronaire hartziekten en JAS-resultaten bij prospektief onderzoek...................101 
12.4.6. De prediktieve validiteit van de $\mathrm{A} / \mathrm{B}-\mathrm{scha}$. van de JAS op individuee 1 voorspelingsnivo....101

12.5. De Nederlandse versie $\operatorname{van}$ de JAS............... 102

12.5.1. De konstruktie van de Nedexlandse A/B-schaal...102

12.5.2. Over de validiteit van de Nederlandse $A / B-$ schaal................................ . . . . . . . . .

12.6. Mederzijase herkenbaarheid $\operatorname{ran}$ de JAS-en de

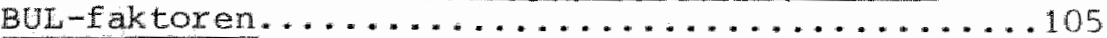

12.6.1. Herkenbarheid van de JAS-faktoren bij de BuL..105

12.6.2. Herkenbaarheld van BUL-Eaktoren bij de JAS....105

12.7. Een vergelijkend onderzoek tussen Type A- en Type

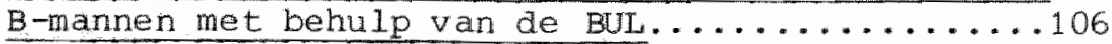

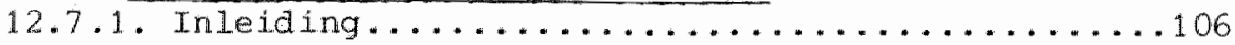

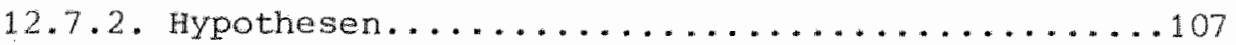

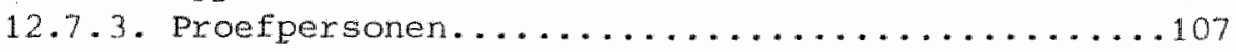

12.7.4. Voorspel1ingen, toetsingen en resultaten.....108

12.7.5. Onderzoeksbevindingen en diskussie............ 108

Hoofastuk 13. SAMENVATTING EN SUGGESTIES VOOR VERDER

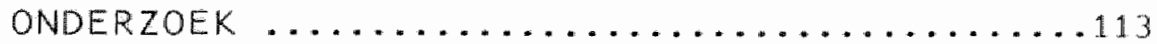

13.1. Betreffende het verrichte eigen onderzoek.......113

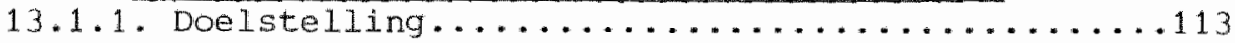

13.1 .2 . Het specifieke ziek tebeela................13

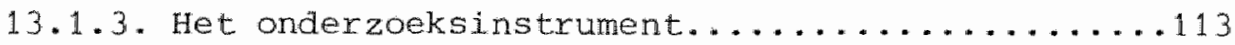

13.1.4. De onderzoeksvariabelen................. 114

13.1.5. Relevant geachte dimensies, gebaseerd op psycho-

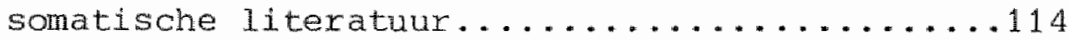

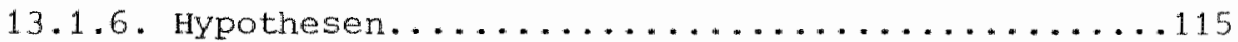

13.1.7. Onderzoeksbevindingen bij hartinfarktpatiënten

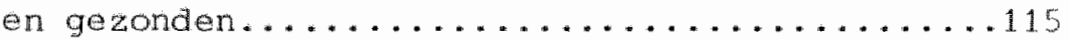

13.1.8. Onderzoeksbevindingen bij hartinfarktpatienten

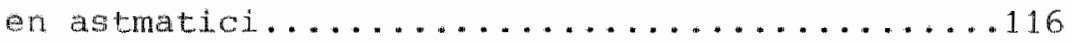

13.1.9. Onder zoksbevindingen bij hartinfarktpatiënten en patienten jijdende aan verschillende ziektebeelden anders dan hartinfarkt en astma bron-

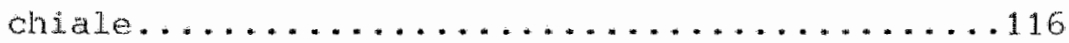

13.1. 10. Konklusies met betrekking tot de onderzoeksbevindingen. . . . . . . . . . . . . . . . . . . 117

13.2. A/B-typologie en Jenkins Activity survey (JAS) . . 118 13.2.1. Definitive en onderzoeksbevindingen..........118 13.2.2. BuL-resultaten bij Type A- en Type B-mannen... 119 
13.3. Suggesties voor verder onderzoek. . . . . . . . . . . 119

13.3 .1 . Inleiding . . . . . . . . . . . . . . . . . . . . 119

13.3.2. Preferenties ten aanzien van onderzoeksopzet....120

13.3.3. Relevant geachte psychologische testvariabelen..121

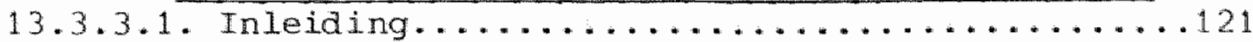

13.3.3.2. Agressiviteit/Hostiliteit.............. 122

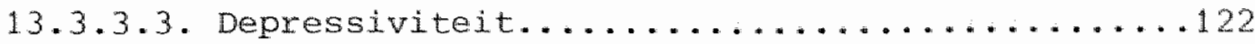

13.3.3.4. Aktiviteit/Werk/Eerzucht/Beroepsverantwoorde-

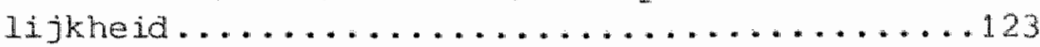

13.3 .3 .5 . Sociabiliteit........................ 124

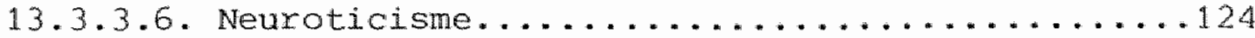

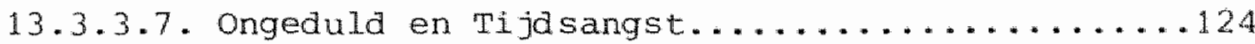

13.3 .3 .8 . Konklusie........................ 125

SUMMARY.

I. MY OWN RESEARCH PROJECT .................

I. 1. Purposes........................... 127

I.2. The "specific" disease picture.............. 127

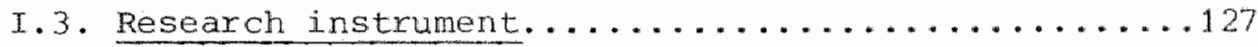

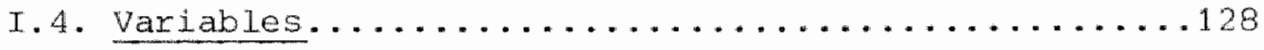

I.5. Relevant dimensions, based on psychosomatic

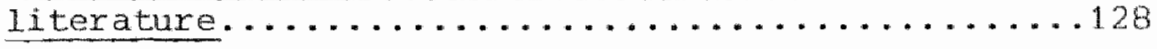

I.6. Hypotheses. .......................... 129

I.7. Research findings on comparing myocardial infarction patients with healthy males............129

I.8. Research findings comparing myocardial infarction patients with asthmatics........................

I.9. Research findings comparing infarction patients and patients suffering from various syndromes other than myocardial infarction and bronchial asthma....130

I. 10. General conclusion....................... 131

II. A/B-TYPOLOGY AND THE JENKINS ACTIVITY SURVEY

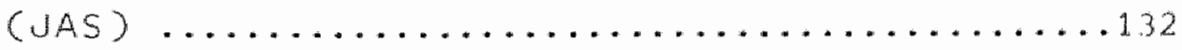

II. 1. Description and research findings............ 132

II.2. R.S.L.-results with Type A and Type B males......133

III. SUGGESTIONS FOR FURTHER STUDY ..........

III. I. Introduction.......................... 
Ir. 2. Ereference with regard to the research design...134

III. 3. Psychological variables considered relevant.....136

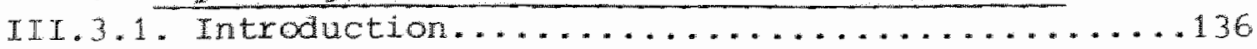

$\operatorname{Ir} .3 .2$. Aggressiveness/Hostility . . . . . . . . . . . 136

III.3.3. Depressiveness......................... . . 137

III.3.4. Activity/Work/Anbition/Job responsibility. . . 138

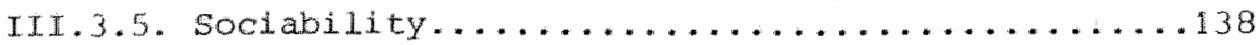

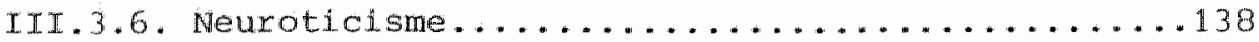

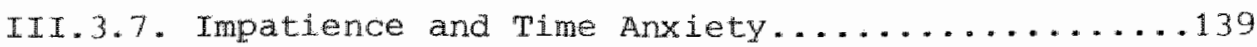

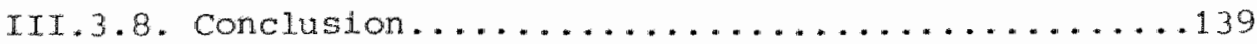

BIULAGE 1. Enkele voorbeelden van BUL-itens................ 141

BIJLAGE 2. Met dank aan de werknemers van de bedrijven en instellingen, die meegewerkt hebben bij de samenstelling van de "gezonde" Basisgroep................... 142

BIILAGE 3. Uittreksel van een verslag betreffende de resultaten van eer faktoranalyse op het BUL-material van de "gezonde" mannen uit de Basisgroep............... 143

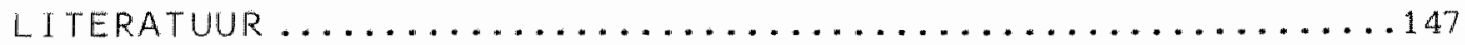

CURRICULUM VITAE 


\section{VOORWOORD.}

Het spreekt vanzeIf, dat tijdens de lange ontstaansgeschiedenis van dit proefschrift de hulp, steun en anmoediging van vele personen een belangrijke rol hebben gespeeld. Erkele van hen wil ik met name noemen.

Ik stel het op prijs in Professor Dr.J.J.C.B. Bremer mijn promotor te hebben gevonden. Hij gaf mij de steun in de rug die ik nodig had on dit proefschrift als zodanig te valtooien. Hiervoor en ook voor de prettige wijze warop dit alles geschiledde, ben ik hem erkentelijk.

Veel kritische opmerkingen en methodologische adviezen heb ik. ontvangen van Professor Dr. J.T. Barendregt. Hiervoor wil ik hem dankzeggen.

Professor Dr.J. Groen heeft mij de voedingsbodem voor mijn onderzoek geboden en wel in de vorm van zijn klinisch-psychologische indrukken van zogeheten psychosomatische patiënten. Daarnaast heeft hij de totstandkoming van het proefschrift inspirerend begeleid en in een voor mij moeilijke levensperiode zijn wijsheid en warme menselijkheid geschonken. Dit heeft op mij een diepe indruk gemaakt.

Veel waardering heb ik voor mijn beide ko-referenten, bij name van Professor Dr.J. Bastiaans en Dr. A. Appels. Beiden hebben belangrijk schaaf-werk verricht aan het manuskript en een aantal uitbreidingen voorgesteld die ik graag heb verwerkt.

De statistische begeleidjng door Drs. G.J.F.P. Hanewald is onontbeerlijk geweest. Hij heeft mij frekwent terzijde gestaan bij de statistische be- en verwerking van het onderzoeksmateriad. In dit kader wil ik ook de namen noemen van Drs. W.N. van Nooten, Drs. R. Potharst, Drs. H. Ellfers en Drs. J. Rijuordt, destijds allen medewerkers van het Mathematisch Centrum te Amsterdam. Naar hen allen gat mijn dank uit. Het beschreven onderzoek vond plats in het kader van de Psychosomatische Werkgroep van het Academisch ziekenhuis bij de Universiteit van Amsterdam, het "Wilhelmina Gasthuis'. Het voormalig Hoofd van deze afdeling, Dr. J.M. Van der Valk, ben ik erkentelijk voor zijn enthousiasme, adviezen en onmisbare aannoedigingen om met het onderzoek door te gaan en voorts voor de ruime mate van vrijheid die hij mij altijd bij het uitvoeren van mijn onderzoekingen geboden heeft. In de rij wan personen die naw bij dit proefschrift betrokken zijn geweest mag de naam van mijn naaste kollega Drs. R. Beunderman niet ontbreken. Schier ontelbare versies van wat eens een proefschrift zou worden heeft hij kritisch doorgelezen en var zijn opmerkingen voorzien. Hierdoor kon het geschrift aammerkelijk opgesierd worden. Daarvoor wil ik hem dank zeggen. 
Een implikatie van de schier ontelbare versies is, dat hiervoor intenslef typewerk verxicht moest worden. In dit verband gaat mijn wardering uit naar de dames A.N. Smith, D.J. Duyvis, M.P.J. Van Gale, E.C. van Dalen en J.H. van Heusden. De Heer G.M.H.J. Van Rooy ben ik exkentelijk voor zijn vele pogingen een omslag te ontwerpen, warin het beeld van een gebroken hart, onbereikbaar gevangen in een onwrikbare en ondoordringbare borstkas, tot uitarukking wordt gebracht.

Mijn erkentelijkheid gaat ook uit naar de heer J.B. Meerstad, die de off-setdruk verzorgd heeft en mij steeds op prettige wijze terzijde heeft gestaan.

Tot slot: velen die op enigerlei wijze bij de wordingsgeschiedenis van dit proefschrift betrokken zijn geweest moeten om praktische redenen ongenoemd blijven of worden elders in deze studie verme la.

Dit betekent niet, dat ik hen allen minder erkentelijk ben voor hun bijdxagen dan degenen, die ik wel in dit voorword met name heb genoend.

H. $\operatorname{van}$ Dijl. 


\section{BETEKENIS VAN AFKORTINGEN:}

AP : angina pectoris

BUL : Beoordelen-van-Uitspraken-Lijst.

BF-I : BUL-Faktor I: Agressiviteit.

BF-II : BUL-Faktor II: Depressiviteit.

BF-III : BUI-Faktor III: Aktiviteit en werken.

BF-IV : BUL-Faktor IV: Eerzucht en Dominantie.

$B F-V$ : BUt-Faktor $V$ : Sociabiliteit.

$B F \rightarrow I$ : BUL-Faktor VI: Beroepsverantwoordelijkheid.

BFen : BUL-faktoren.

chz(en): coronaire hartziekte $(n)$.

COPIH : Commissie Opsporing en Preventie van Ischemische Hartziekten

CHD : coronary heart disease.

ECG : electrocardiogram.

H : Hard-driving; één van de drie JAS-faktoren.

Hips : hartinfarktpatiënten

IMIR : Imminent Myocaraial Infarction Rotterdam.

J : Job-involvement; één van de arie JAs-faktoren.

JAS : Jenkins Activity Survey.

M : rekenkundig gemiddelde.

MPI : Minnesota Multiphasic Personality Inventory.

$n$ : aantal.

S : Speed and Impatience; én van de drie JAs-faktoren.

SD : standard deviatie.

wCGS : Western Collaborative Group study. 

INLEIDING

\subsection{Terrein en afbakening}

In november 1947 werd door Dr. J. Groen, internist, In hot Wilhelmina Gasthuis in Amsterdam, met steun van de Rockefeller Fonindation, de Psychosomatische Werkgroep opgericht.

Hij en zijn toenmalige medewerkers gingen ex toentertijd vanuit, "dat psyche en soma verschillende manifestaties van het levensgebeuren voorstellen, die met elkaar onafscheidelijk zijn verbonden en voortdurend intensief invloed op elkaar uitoefenen" (Groen e.a., 1950).

De wetenschap die zich bezighoudt met het bestuderen van het verband tussen "psyche" en "soma", duidden zilj aan als psychosomatiek of psychosomatologie.

Bovengenoemd uitgangspunt impliceert een breed werkterrein, doch Groen e.a. (1950) bakenden hun studieterrein af door hun psychosomatische onderzoekingen voornamelijk tot lijders aan "organische" ziekten te beperken.

Het onderhavige onderzoek zal op deze afbakening aansluiten en gebaseerd zijn op de veronderstelling, dat ex een relatie bestaat tussen het vertonen van een "organisch" ziektebeeld en het zich onderscheiden op bepaalde psychologische onderzoeksvariabelen. Het gaat in deze derhalve niet om de Ellosofische problematiek betreffende het verband tussen "lichaam en ziel", maar om een poging te komen tot toetsbare uitspraken. Bij hun onderzoekingen maakten Groen e.a. (1950) gebruik van voornamelijk de methode der biografische anamnese met toepassing van het psychoanalytische begrippenkader.

Het feit, dat daarbij ook een psycholoog met behulp van een psychologische test gegevens tracht te verzamelen, die latex vergeleken werden met bevindingen, verkregen via de genoemde klinische methode der biografische anamese, toont aan, dat deze onderzoekers oog hadden voor een wetenschappelijke beperktheid van de door hen gebruikte methode. Er kleeft irmers het bezwaar aan, dat de uitkomsten sterk beinvloed kunnen zijn door de persoonlijke insteliling van de onderzoeker. Ook zelf stelden zij blijkbaar de eis, dat de uitkomsten van de ene onderzoeksmethode geverifieerd dienen te worden met die verkregen via een andere methode.

Reeds vanaf het begin van het bestaan van de Psychosomatische Werkgroep hebben psychologische medewerkers dan ook diverse pogingen ondernomen an bepalde klinische bevindingen te toetsen met behulp van meer objectieve methoden (vles en Groen, 
1951, 1952; Barendregt, 1954, 1954a, 1956, 1958, 1961;

Barenaregt e.a., 1958; Barendregt en Cornelissen, 1955;

Barendregt en Groen, 1953; Wilde, 1960, 1962; Wilde en

Baxendregt, 1957; van Dij1, 1967; van Difl en Olthuis, 1970;

van Dijl, 1975).

ook in deze studie zal van een dergelijk onderzoek verslag worden uitgebracht.

\subsection{Doelstelling}

Bepalide bevindingen, verkregen tijdens psychosomatische onderzoeklngen bij lijders aan "organische" ziekten, brachten Groen e.a. (1950) tot het opstellen van de hypothese der psychosomatische specificiteit.

Bij een beschrijving van deze hypothese door Groen e.a. uit 1965 wordt onder meer nadrukkelijk gesteld, "dat voor het ontstaan van een specifiek ziektebeeld drie factoren noodzakelijk zijn: een bepaalde persoonlijkheidsstructuur, een bepaalde tussermenselijke conflictsituatie en een bepaalde wijze van gedrag in zulk een situatie".

Bezien wij bovenstaande omschrijving van de specificiteitshypothese, dan blijkt deze te ruim om van hypothese te kunnen spreken. veeleer wordt hiermee een onderzoeksprogramma weergegeven, waarbij vele, nog nader af te leiden hypothesen, getoetst kunnen worden. Zo zou voor diverse ziektebeelden dienen te worden nagegaan, of deze samenhang vertonen met specifieke persoonlijkheldsvariabelen. Het onderhavige onderzoek zal echter het hele onderzoeksprograma dat in de specificiteitshypothese vervat ligt, bij lange na niet bestrijken, maar zich beperken tot twee afzonderlijke ziektebeelden plus een kategorie, bestaande uit een verscheidenheid aan ziektebeelden (zie 1.3).

Bij de beschrjjving van de hypothese der Psychosomatische Speciflciteit wordt gesproken over het ontstaan van een specifiek ziektebeeld. In verband met het retrospektieve karakter van het onderzoeksmateriaal zal het onderhavige onderzoek geen betrekking hebben op ait ontstaan. Voorts zal het beperkt blijven tot de eerst genoemde faktor: een bepalde persoonlijkheidsstruktuur. Hierbij moet worden opgemerkt, dat het begrip "persoonlijkheidsstruktuur" bij een empirisch onderzoek moeilijkheden met $z i c h$ meebrengt vanwege de onmogelijkheid dit begrip te operationaliseren. Deze term zal dan ook getransformeerd worden naar: "personen die zich onderscheiden op bepaalde psychologische onderzoekvariabelen", zodat de doelstelling van dit onderzoek omschreven kas worden als: het toetsen van de hypothese, dat personen met een specifiek ziektebeeld zich op bepalde psychologische onderzoekvariabelen onderscheiden van personen 
die niet aan dat specifieke ziektebeela lijath.

1. 3. Keuze van een experimentele medisch-diagnostisch bepaalde patiêtengroep en van kontrolegroepen.

Als "specifiek ziektebeeld" werd het haxtinfarkt gekozen.

Bovengenoemde hypothese zal getoetst worden middels een vergelijking van een bepaald onderzoeksmaterlad l akomstig van mannelijke hartinfarktpatiënten met dat afkomstig van:

a. "gezonde" mannen;

b. mannelijke astmatici;

c. mannen met medische diagnoses anders dan hartinfarkt en astma bronchiale.

op grond van resultaten, verkregen bij een eerder onderzoek van Dijl, 1967, 1973), zal bij deze toetsing van voornamelijk een vorm van zelfbeoordeling gebruik gemalkt worden. 
HOOFDSTUK 2.

HET ONDERZOEKSINSTRUMENT.

2.1. Het ontstaan van de Beoordelen-van-Uitspraken-Lijst (BUL).

2.1.1. Herkomst van de items.

Gezien het in 1.3. genoemde onderzoeksresultaat leek het zinvol om met behulp van beoordelingsgedrag de toetsingsmogelijkheden van de hypothese der Psychosomatische specificiteit uit te breiden. Daartoe werden persoonlijkheids- en gedragsbeschrijvingen van hartinfarktpatiënten (Hips) en astmatici doorgelezen (Groen e.a., 1965; Dunbar, 1948; Arlow, 1945; Groen, 1950).

Deze beschrijvingen vormden de basis voor het genereren van testitems, die gesteld werden in de vorm van uitspraken. Deze werden voorzien van beoordelingsschalen, bestaande uit twee tegengestelde omschrijvingen met daartussenin een 6-punts beoordelingsschal. Zie onderstaand voorbeeld.

1. Het weer heeft op mijn stemming:

helemaal geen invloed:--: --:--1--:--:--: heel veel invloed. Door het plaatsen van een kruisje in één der 6 schaalsegmentjes kan een proefpersoon aangeven in welke mate hi.j éen van de twee omschrijvingen van toepassing vindt.

Het werd - gezien de beschrijvingen en veelvuldig voorkomende uitspraken van bedoelde psychosomatische patiënten zelf mogelijk geacht, dat Hips enerzijas en astmatici en "gezonden" anderzijds, bij het beoordelen van deze uitspraken (items) verschillen zouden vertonen.

De test kreeg de naam: Beoordelen-van-Uitspraken-Lijst (BUL)

en bestaat uit 69 items. Met deze test werden de nog nader te noemen onderzoekingen verricht. Zie bijlage 1 voor uitgebreider informatie over deze test.

2.2. De Basisgroep "gezonden".

2.2.1. Kriteria voor "gezond". Aangezien het in de bedoeling lag om met de BUL een vergelijkend onderzoek te doen tussen enerzijds "gezonden" en anderzijds astmatici en Hips, werd een kontrole groep van "gezonden" geformeerd, bestaande uit personen, die niet leden of ooit geleden hadden aan symptomen van ziekten van:

a. hart-en bloedvaten (hartinfarkt, angina pectoris, hypertensie);

b. de ademialingswegen (astma, bronchitis).

Om"gezond-zijn" dichter te benaderen leek het zinvol er naar 
te streven, dat deze groep ook geen personen zou bevatten die Joden aan of oojt geleden hadden aan symptomen van ziekten van:

c. hot mag-darm kanal (ulcus ventriculi et duodent colitis ulcerosia).

Een aantal klinische onderzoekers kwalificeren psychosomatische patiënten als"neurotisch" (Groen, 1950; Treurniet, 196;; Bastiaans, 1968; 1975; 1977).

op grond daarvan werden van de groep "gezonden" ook witgesloten personen die:

d. wegens psychische klachten ooit met een psychiater of psycholoog in kontakt waren geweest.

2.2.2. Herkomst van de "gezonde" proefpersonen uit de Basisgroep. Teneinde een dergelijke groep "gezonden" te kunnen samenstelien werd kontakt gezocht met een aantal bedrijven en instellingen. De direkties van deze bedrijven werd toesteming gevraagd om een aantal aldaar werkzame mannen uit te nodigen de BUL in te vullen. De bedrijfsartsen werden hetzij vór, hetzij ná het invulien gevraagd die mannen te selekteren, dievooxzover zij dat wisten- "gezond" waren en met name voldeden aan de eerder genoemde 4 kriteria (zie 2.2.1.).

Bij een aantal bedrijven bleek geen bedrijfsarts aanwezig. Daar hebben wij middels een brief de mannen gevxaagd alleen mee te doen als zij "gezond" waren en voldeden aan de in 2.2.1. gestelde kriteria.

Het deelnemerspercentage bleek over de bedrijven en instellingen te variëren tussen 50 en $90 \%$.

Voor ons doel in aanmerking komende manner werden per brief uitgenodigd mee te doen, waarna het invullen van de BUL kollektief in werktijd plaatsvond.

Op deze wijze konden ruim 1300 BUL-protokollen verzameld worden, ingevuld door mannen voornamelijk werkzaam in Amsterdam en onstreken. Iets minder dan $1 / 6$ deel van de deelmemers was werkzaam in Joure (Friesland). Zie bijJage 2 voor de bedrijven en instellingen, die hum medewerking hebben vexleend. Verreweg het merendeel is afkomstig van manmen, die doox de bedrijfsartsen geselekteerd werden.

2.3. Statistische bewerkingen van de BUL.

2.3.1. Indeling in leeftijds-en opleidingsklassen. Tijdens de uitwerking van de BuL-protokollen van de Basisgroep viel het op, dat er een verband leek te bestaan tussen enerzijds het kiezen van uiterste schadiposities over de 69 items (a.w.z.: het platsen van een kruisje in het meest linkse of 
of meest rechtse schadsegment) en anderzijas:

d. Leeftija;

b. opleidingsnivo.

Deze indruk vornde aanleiding on het material in 5 leeftijdsklassen en elke leeftijdsklasse in 3 opleidingsnivo's in te delen. Zo ontstonden de leeftijasklassen:

1. $15 \mathrm{t} / \mathrm{m} 24$ jaax:

2. $25 \mathrm{t} / \mathrm{m} 34$ jaar:

3. $35 \mathrm{t} / \mathrm{m} 44$ jaar;

4. $45 \mathrm{t} / \mathrm{rm} 54$ jaar;

5. $55 \mathrm{t} / \mathrm{m} 65$ jaar.

De 3 opleidingsnivo's worden als volgt begrensd:

Nivo I een L.S., L.T.S., E.T.S.-opleiding of een ekwivalent:

Nivo II een M.U.L.O., M.A.V.O., Handelsschoolopleiding of een equivalent;

Nivo III een H.B.S., een Gymnasium, H.A.V.O., Universitaire opleiding of een ekwivalent.

Eldexs werd van het verband tussen het kiezen van extreme schaalposities enerzijds en leeftijd en opleidingsnivo anderzijds, verslag uitgebracht (van Dijl en olthuis, 1970;

olthuis, 1972).

2.3.2. De faktoranalyse.

Gezien de bronnen, die de basis vormden tot het genereren van de items, leek het zinvol de BUL te Eaktoranalyseren. Tmmers, verschillende auteurs beschrijven dikwijls in andere bewoordingen dezelfde "trekken" of gedragingen die Hips van bijvoorbeeld "gezonden" zouden onderscheiden. Het leek derhalve aannemelijk, dat de 69 BuL items tot een relatief klein aantal geclusterde variabelen teruggebracht konden worden. Voor deze faktoranalyse werd gebruik gemakt van de skores van 1336 mannen (Basjsgroep) op 71 variabelen.

Variabele $11 s$ de leeftija van de desbetreffende proefpersoon, vatiabele 2 het opleidingsnivo (zie 2.3.1.) en de overige 69 variabelen worden gevorma door de antwoorden op de 69 BUL i.tems. Voor elk van deze items bestonden 6 geordende antwoordmogelijkheden, genmmerd (var links naar rechts) van $1 \mathrm{t} / \mathrm{m} 6$. De faktoranalyse werd uitgevoerd volgens de methode van

Achteraf beschouwen wij het onjuist de variabelen leeftijd en opleiding in de analyse te hebben opgenomen. Immers, wij zijn op zoek naar aimensies om "pexsoonlijkheidskenmerken" mee te kunnen meten. In het onderhavige geval hebben leeftijd en opleiding daarbinnen geen plates. wie in dit verband ook 2.3.3. en 2.3.5. 
Jöreskog (1963), d.w.z. met extraktie van orthogonale faktoren. Vanwege o.a. het gegeven, dat bij 8 faktoren het percentage verklaarde variantie 24,82 bedraagt en bij 6 faktoren reeds 22,29 èn dat faktor VIII slechts ë́n item met een relatief hoge lading bevat en derhalve oninterpreteerbaar is, werd gestopt bij 8 faktoren (zie bijlage 3).

Om de (geschatte) skore op een geëxtraheerde faktor te kunnen berekenen werden faktorskore-koefficiënten berekend volgens de methode van Anderson en Rubin (Jöreskog, 1963).

Bij het bepalen van een skore op een faktor zijn de faktorskore-koëfficiënten van alle 71 variabelen betrokken: De standaardafwijkingen van de ladingen van de ongeroteerde faktoren (behalve bij faktor VI en VII) bleken van zo'n grootte orde te zijn, dat deze ladingen redelijk nauweurig geschat zijn (zie bijlage 3).

Alleen de eerste 6 faktoren zullen beschouwd en benoem worden aangezien het toevoegen van de faktoren VII en VIII bij de voorafgaande faktoren zo goed als geen verbetering blijkt op te leveren in het percentage verklaarde variantie (zie bijlage 3 ).

2.3.3. Het benoemen van de faktoren.

In de tabellen 2.1. $t / m$ 2.6. staan de variabelen vermeld, die op deze $6 \mathrm{BUL}$-faktoren (BFen) relatief hoog laden na rotatie van 8 faktoren volgens de varimax methode. Aan de hand van het gemeenschappelijke in de inhoud van de diverse variabelen zijn deze BFen als volgt te benoemen:

EUL-Faktor I (BF-I) : Agressiviteit (zie tabel 2.1.). BUL-Faktor II (BF-II) : Depressiviteit (zie tabel 2.2.). BUL-Faktor III (BF-III): Aktiviteit en worken (zie tabel 2.3..). BUL-Faktor IV (BF-IV) : Eerzucht/Doninantie (zie tabel 2.4.) De relatief hoge ladingen van leeftija en opleiding geven aan, dat BF-IV voor een belangrijk deel door deze variabelen is samengesteld. Dit makkt, dat de benoeming Eerzucht/ Dominantie met de nodige reserve bekeken moet worden (zie tabe1 2.8.).

BUL-Faktor V $\left(B F^{-}-V\right)$ : Sociabiliteit (zie tabe1 2.5.). BUL-Fiaktor VI (BF-VI) : Beroepsverantwoordelijkheld ( zie tabe1 2.6.).

verondersteld wordt, dat men via het beoordelen van uitspraken die betrekking hebben op:

(1) Agressiviteit, zoals gemeten door BF-I, de mate aangeeft waarin men zichzelf agressieve gevoelens en gedachter toeschrijft; 
g.

क⿺辶

$\rightarrow$. I .

(5)

(1) 2 .

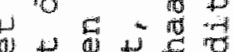

का मे

of 0

a 0 क ज क

10 $\mathrm{E} M \mathrm{M}$

4. 0 rid w of

if 0 ० 0

यो को का

$\Rightarrow$ di

o r a d o

4 4 에 0

0 \& 1

अ 4 की

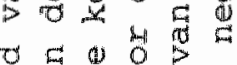

a ton 0

a $13>0$

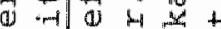

$\rightarrow 000$ म

a 4 का मो

(n)

(1) $\sum_{0} 4-10$

0 of 4 is

a

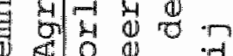

(4) $\because 4$ y

(1) 4 in

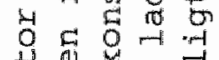

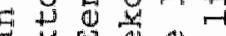

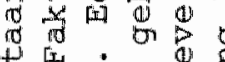

4. [1 में 0 .

$a_{0}=0$ 年

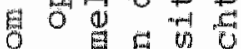

तो 0 Q

$8 \times 5$ का

(1) 8 क ज

+

in 0 -

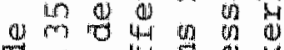
7.40

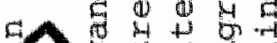
a

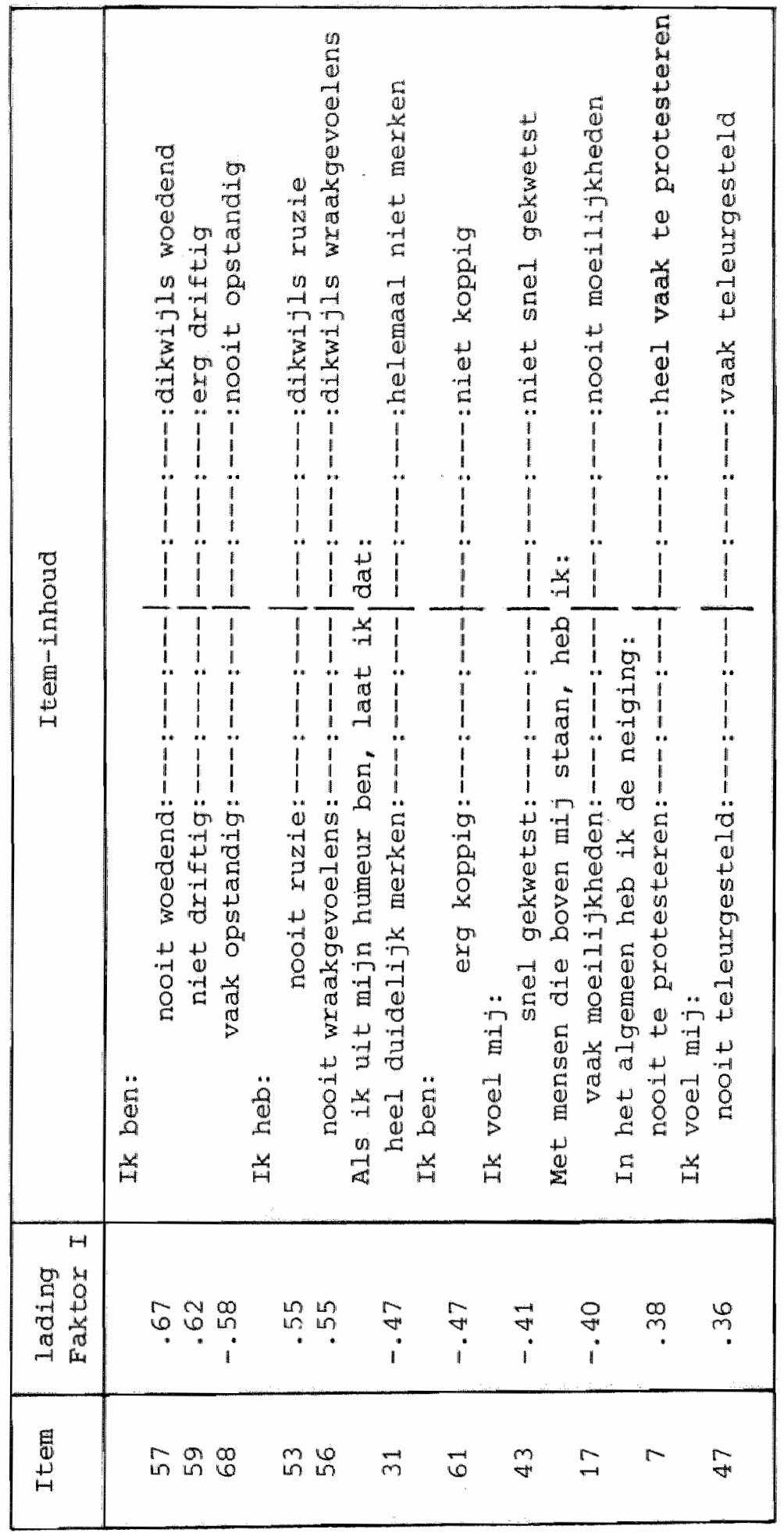




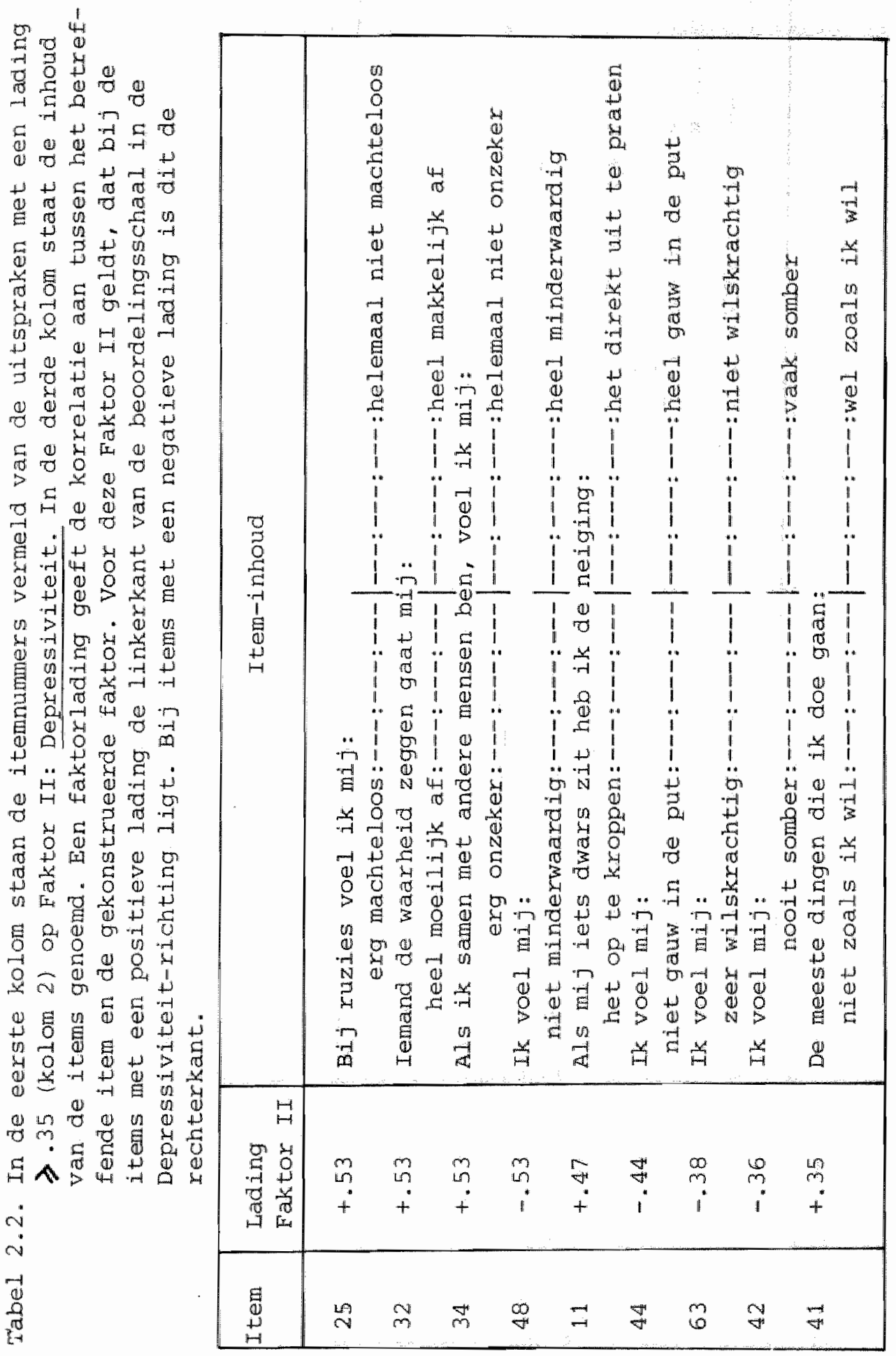




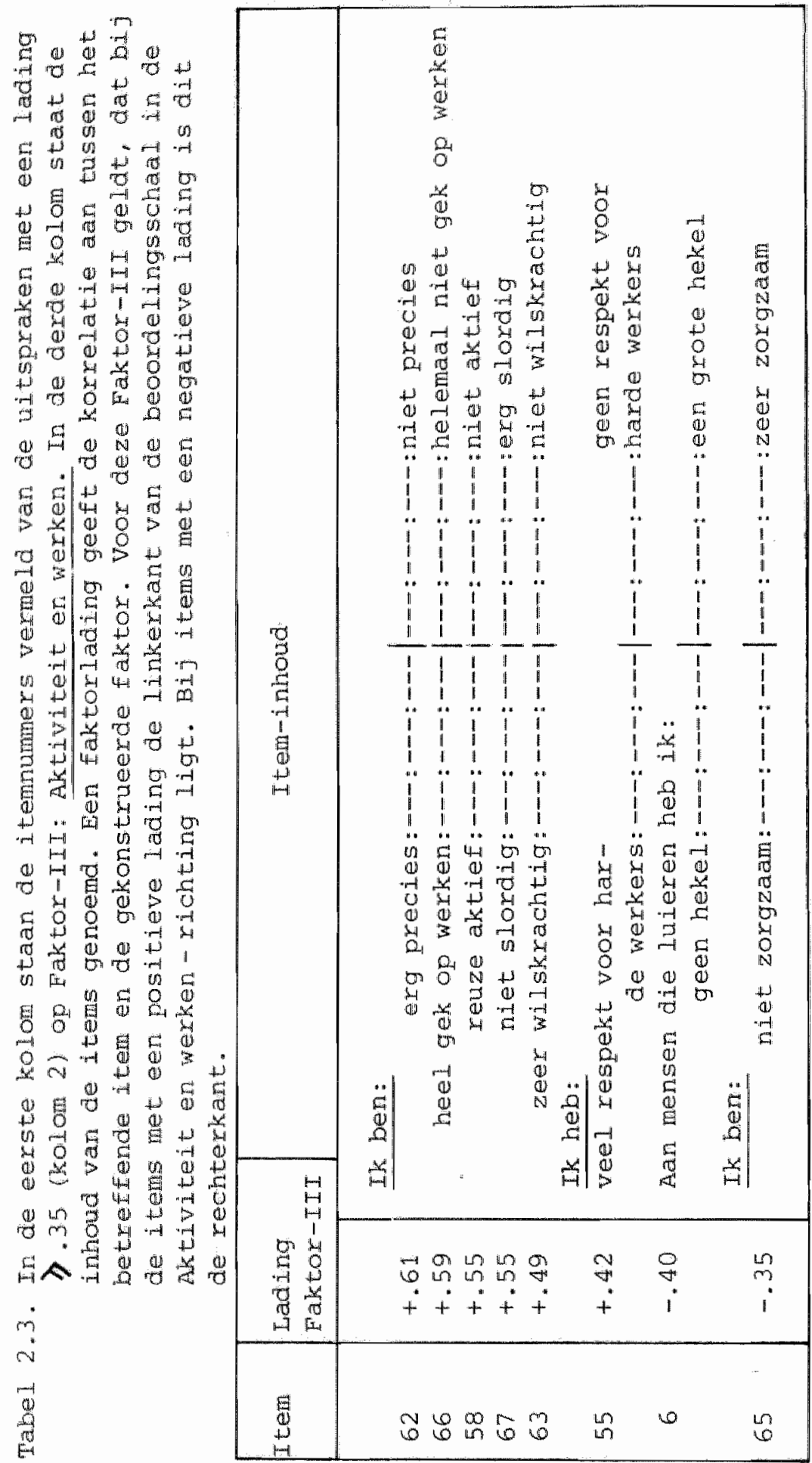




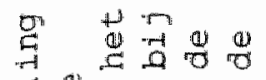

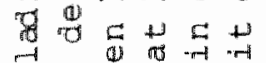

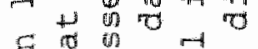
ब1 4 बा 0 व

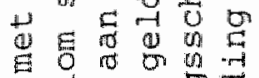
द 0 a (1) $\rightarrow$ H

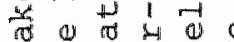

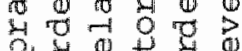
in at ox o + to 車。的罗 (1) व 5 क षै⿴囗十

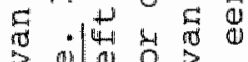

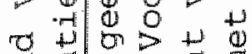
可

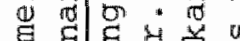
\&

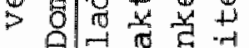
o 1 出 4 . y t.

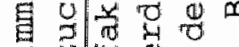

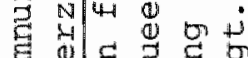

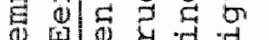
+ 国 0 灷 ( 1 ह है

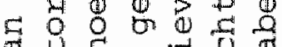
(3) I

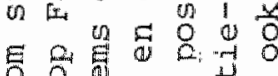
$\rightarrow$ 据 ำ

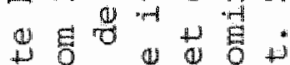
on $\Rightarrow$ W क क्ष ชก

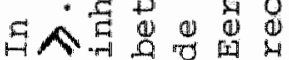
নं

\begin{tabular}{|c|c|c|c|}
\hline & \multicolumn{2}{|c|}{ 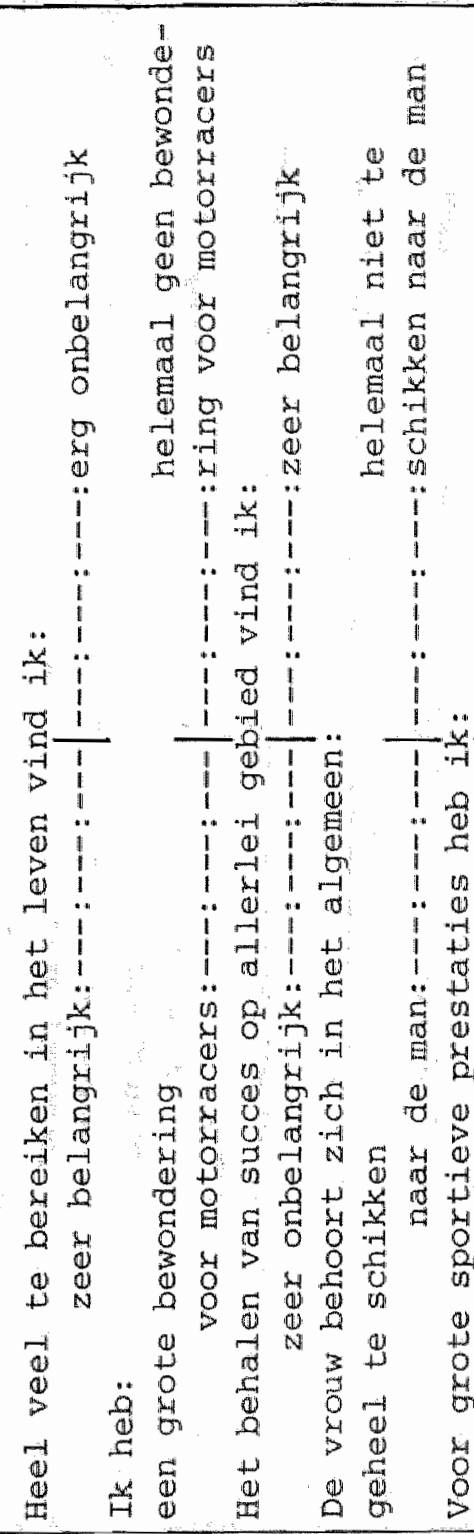 } & 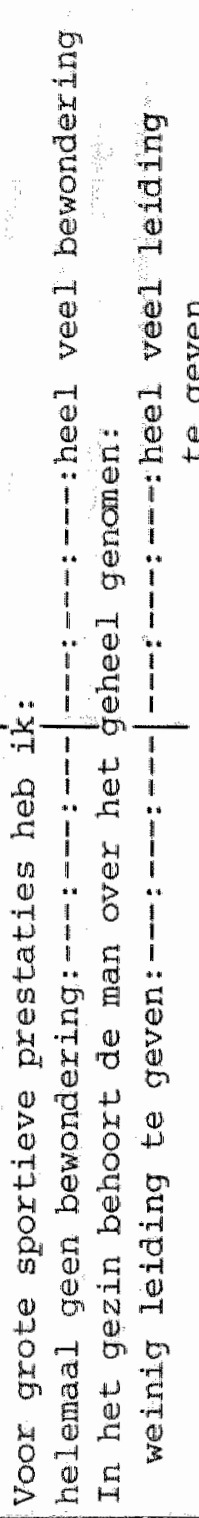 \\
\hline 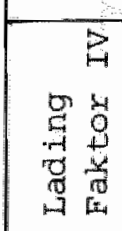 & 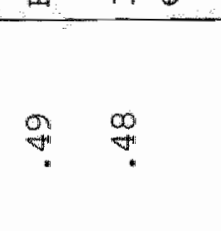 & 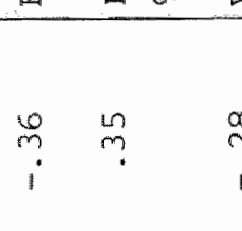 & $\begin{array}{ccc}\stackrel{\infty}{y} & \stackrel{\sim}{i} \\
i & \end{array}$ \\
\hline & & & \\
\hline
\end{tabular}


다 ซ

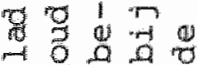

हा है

बiin

4) 0 (1)

(2) 0 th 10 ro

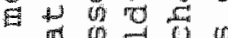

$\rightarrow$ of 0

i) 10 o

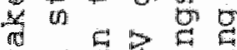

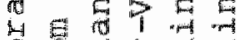

员

(i) 0 o 000

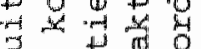

(1) तो is 0

a)

(1) 4 a na

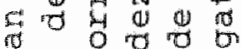

$\rightarrow 020$

${ }^{\circ} 04$

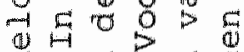

政

讨出

$>-7$ o

on 1 o

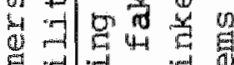

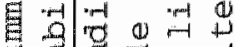

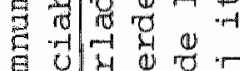

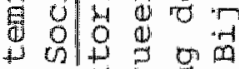

- 1 ..

$\Leftrightarrow \ddot{4}$ or

서의 영

क to

(1)

जै

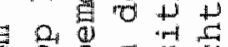

的品

和政

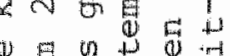

if -1 (1)

40 tis of the

(1)

(4)

ते

EA

wi

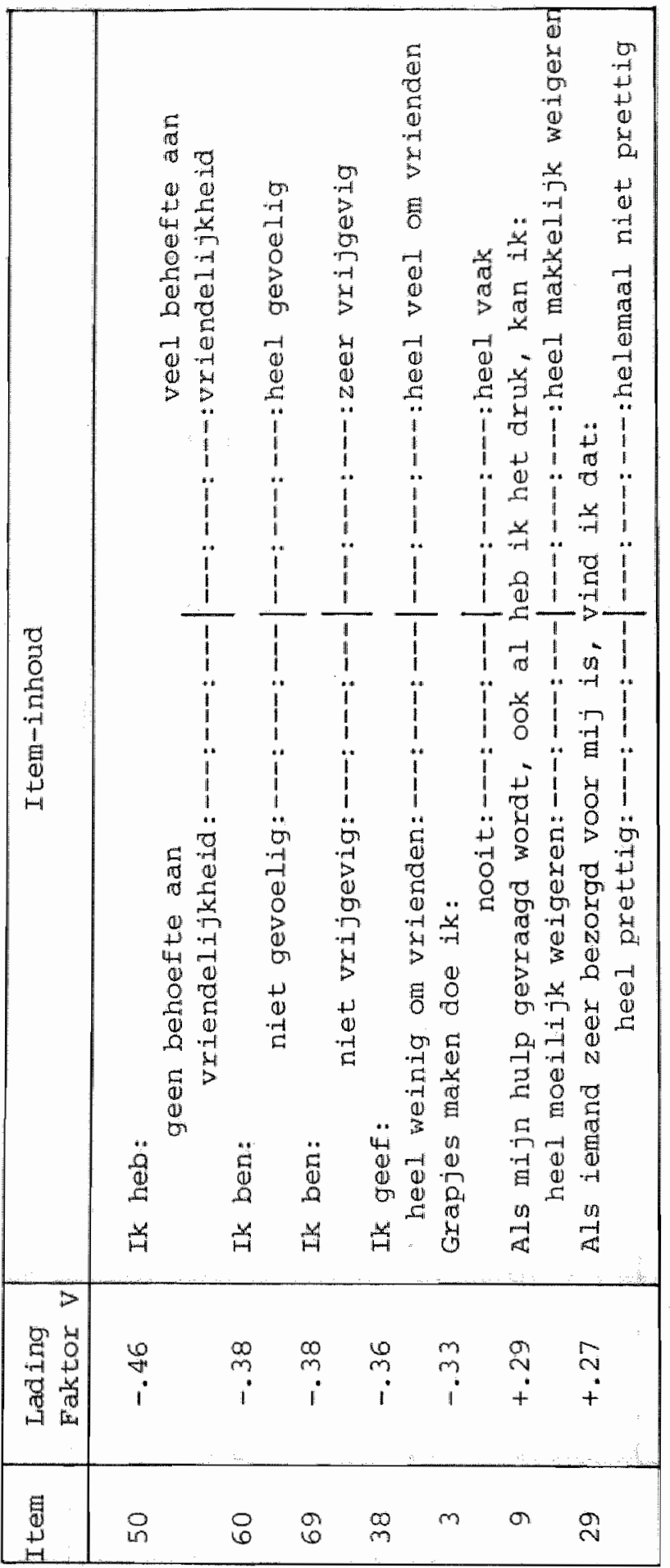




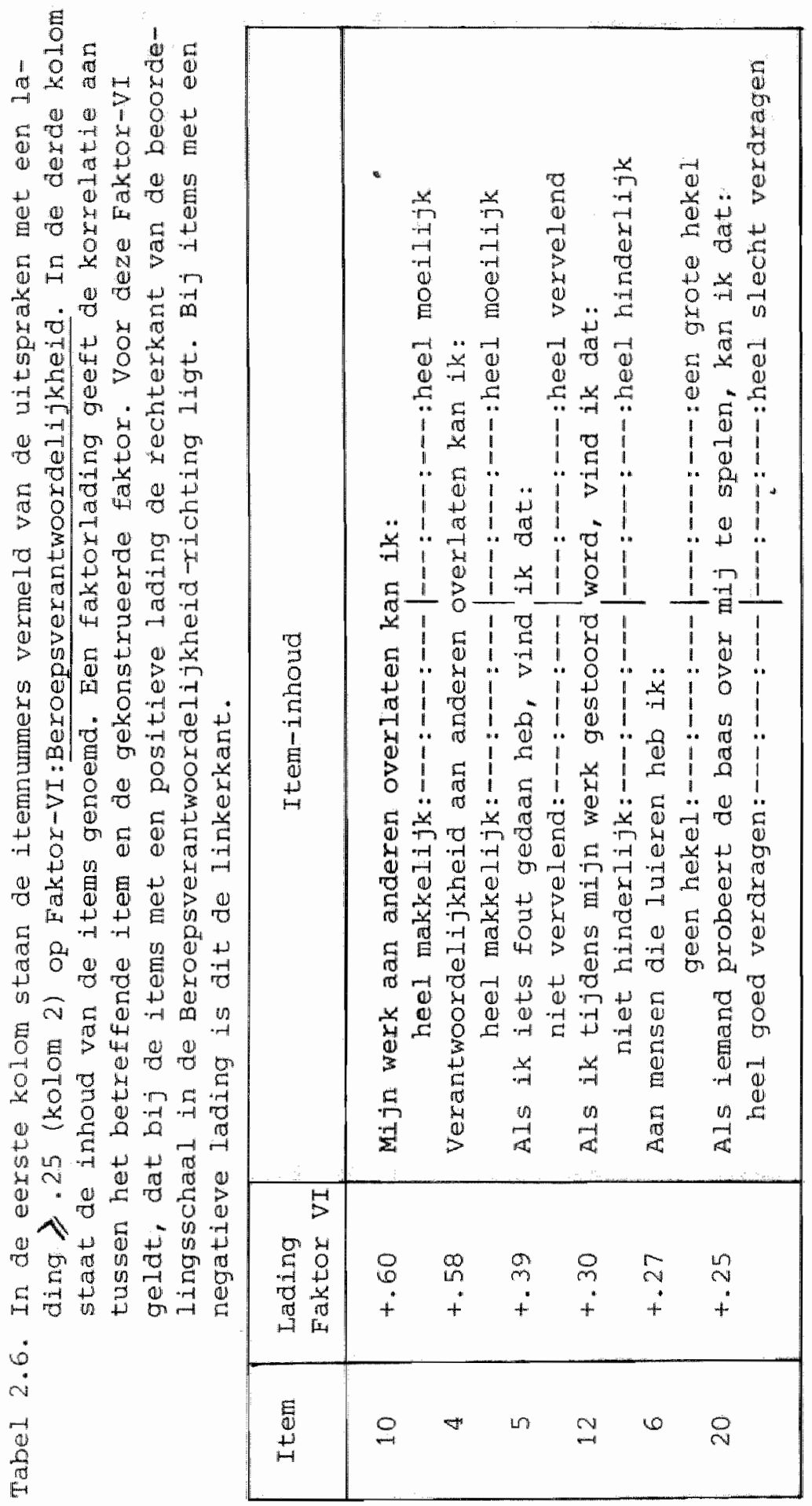


(2) Depressiviteit, zoals gemeten door BF-II, de mate aangeeft waxin men zichzelf depressief voelt en in staat tot reageren in "moeilijke" sociale situaties.

(3) Nktviteit en werken, zoals gemeten door BF-III, de wardering voor aktief-zijn en werken en voor de precisie warmee een taak volbracht wordt, tot uitaruking brengt.

(4) Eerzucht/Dominantie, zoals gemeten door BF-IV, de mate aangeet, wariri men zichzelf door "eerzucht" en "dominantie" gekemmerkt vindt. zie echter de opmerkingen boven over deze BF-IV.

(5) Sociabiliteit, zoals gemeten door $B F-V$, de mate aangeeft warin men gesteld is op omgang met mensen.

(6) Beroepsverantwoordelijkheid, zoals gemeten door BF-VI, de mate van gevoelde vexantwordelijkheid voor en/of betrokkenheid bij het werk, tot witdrukking brengt.

2.3.4. Betrouwbararheid van de BUL-Faktoren.

De betrouwbarheid van de 6 BFen werd nagegaan an de hand van test-hertest Pearson korrelatiekoëficiënten (zie tabe1 2.7.). Deze zijn gebaseerd op de skores van 64 mannelijke eerste jaars psychologie studenten aan de Universiteit van Amsterdam. In 1972 vulden deze studenten, in het kader van de zogeheten "testweek", de BuL met een tussenliggende tija van 7 dagen, tweemal in. Het feit, dat deze gegevens verkregen zijn aan eerste jaars psychologie studenten makt de generaliseerbaarheid naar de bij het onderhavige onderzoek betrokken groepen kwestieus. In het algemeen wordt aangenomen, dat een $r=D .80$ als een redelijke maat voor betrouwbaarheid kan worden aangemerkt.

2.3.5. De waarde $\operatorname{van}$ BUL-Faktor IV.

De waarde van BF-IV (Eerzucht/Dominantie) als dimensie om een persoonlijkheidskenmerk te meten, valt te betwijfelen, gezien de rellatief hoge ladingen van de variabelen leeftijd en opleiding (zie 2.3.3.).

Op grond hiervan werd $B F-I V$ in het nog te vermelden onderzoek dan ook niet gebrulkt. Aangezien leeftija en opleiding op de 5 overblijvende BFen betrekkelijk geringe ladingen te zien geven, menen wij deze BFen wel te kunnen gebruiken (zie tabe1 2.8.).

Alvorens het uitgevoerde onderzoek te beschrijuen zal in de volgende hoofastukken eerst literatuur worden besproken die aamsluit bij de te gebruiken 5 BFen. Daarna zullen uit genoemde klinische literatuux toetsbaar geachte hypothesen worden afgeleid. 
Tabel 2.7. Test-hertest Pearson korrelatiekoëfficlënten van 64 mannelijke eerste jaars psychologie studenten, die de BuL met een tussentija van 7 dagen tweemal invulden.

\begin{tabular}{|l|c|}
\hline BF & $\begin{array}{c}\text { Korrelatie } \\
\text { koëfficiënt }\end{array}$ \\
\hline I & .79 \\
II & .81 \\
III & .85 \\
IV & .83 \\
V & .77 \\
VI & .82 \\
\hline
\end{tabular}

Tabel 2.8. Faktor ladingen van de variabelen leeftijd en opleidingsnivo op 6 EUL-Faktoren.

\begin{tabular}{|c|c|c|}
\hline $\begin{array}{l}\text { BUL } \\
\text { Faktor }\end{array}$ & Leeftijd & $\begin{array}{l}\text { Opleidings } \\
\text { nivo }\end{array}$ \\
\hline$I$ & -.00 & +.15 \\
\hline$I I$ & -.06 & +.06 \\
\hline III & -.26 & -.00 \\
\hline IV & +.53 & +.32 \\
\hline$V$ & -.08 & +.01 \\
\hline$V I$ & +.09 & -.12 \\
\hline
\end{tabular}




\section{HOOFDSTUK 3.}

\section{AGRESSIVITEIT BIJ PATIENTEN MET EEN CORONAIRE HARTZIEKTE, EEN LITERATUUR STUDIE}

3.1. Inieidende opmerkingen.

In vele onderzoekingen worden vaak een aantal verschillende psychologische aspekten als min of meer specifiek voor personen met een coronaire hartziekte ( $\mathrm{CHz})$ beschreven. In de hiernavolgende vijf hoofdstukken zullen deze worden samengevat en bediskussiëerd en wel geordend naax een bepaalde karakteristiek of persoonlijkheidsvariabele.

In een aantal gevallen bleek het nodig om bij het refereren van onderzoeksresultaten een wat uitgebreide beschrijving te geven van de wijze waarop deze werden verkregen. Om herhaling te voorkomen, zal op de geẻigende plaatsen van terugverwijzingen gebruik gemaakt worden. Voor het onderzoek naar psychologische faktoren bij coronaire hartziekten (CHzen) is baanbrekend werk verricht door de Amerikaanse cardiologen Rosenman en Friedman. Zij formuleerden de zogenaamde A/B-typologie. De daarop gebaseerde Jenkins Activity survey (JAS) en de hiermee verkregen resultaten zullen in hoofdstuk 12 worden besproken, waarna de JAS variabelen vergeleken zullen worden met die van de BuL.

De literatuurgegevens betreffende de via de But onderscheiden Faktoren (zie 2.3.3.) zullen steeds onder 3 hoofden ter sprake worden gebracht:

(1) Bevindingen gebaseerd op interview-, biografisch anamnestische- en projektietestgegevens.

(2) Bevindingen gebaseerd op indelingen in door de onderzoeker(s) zelf min of meer omschreven kategorieën.

(3) Bevindingen gebaseerd op vergelijkend psychologisch testgedrag, met statistische bewerkingen.

3.2. Aqressiviteit bij hartpatiënten, bezien vanuit de psychosomatische literatuur.

3.2.1. Bevindingen gebaseerd op interview-, biografisch anamnestische- en projektietestgegevens.

Reeds in 1945 wordt in de psychosomatische literatuur geattendeerd op verstoringen in de agressieregulatie bij CHzpatiënten. Arlow brengt de angst van deze patiënten in verband met agressiviteit en wel als kompensatie: "When the fagade of felgned omnipotence is ripped away, the patient is forced to face his inner sense of weakness and fear. These 
are the very feelings which the patient tried to exclude from conscienceness by compulsive aggression". En voorts: "The coronary patient denies his fear, he mask his anxiety by transforming it into aggression" (Arlow, 1945). Aan de hand van Rorschachauidingen stelt kemple (1945): "..." they manifest a persistent pattern of aggressiveruess.." . "Although they try to keep their strong aggressive impulses under control, they manage to justify to themselves a good deal of outwardly expressed hostility".

op grond van haar interviewgegevens legt Dunbar ( 1948 ) verband tussen hun agressie en hun verhoogde emotionele kwetsbaarheid: "These patients were characterized by aggression and resentment which was always faixly near the surface, but volcanic outbursts were rare. They showed an extreme sensitivity and readiness to be insulted".

Vanuit biografisch-anamnestische gegevens komt kits van Heyningen (1960) tot de volgende uitspraken: "They often say:

I can stand arything but unfairness. But in their actual behaviour they suppress their aggression towards others. They will tell you how they manage to behave calmly while inwardly they feel like killing.... In line wil th this way of dealing with aggression we often found fantasies of accidents, dreams of killing and being killed, of blood and fightings".

Eveneens op basis van biografisch-amamnestische onderzoeksgegevens komen Groen en van der valk (1965) tot de volgende karakterisering: "Het betreft mannen, die men in hun uiterlijk gedrag zou kunnen beschrijven als actief of agressief met een tendens tot dominantie".

Treurniet (1965) signaleert: "When they are challenged or slighted they feel like fighting back fiercely. Their fantasies are often full of bloody incidents".

Appels (1972) vat de aan patiënten met een coconaire hartziekte toegeschreven psychologische kenmerken samen onder : "overactiviteit" en "zelfcontrole". Onder "overactiviteit" valt volgens hem ook verhoogde agressiviteit.

Cleveland en Johnson (1962) vergeleken Rorschachduidingen van 25 gehospitaliseerde Hips met die van 25 controles "awaiting serious surgery". zij makten gebruik wan een mat voor "Hostility", ontleend aan Elizur (1949).

De Hips skoorden signifikant hoger in de hostiliteit-richting $(\mathrm{p}<.05)$.

Miller (1965) onderzocht 34 Hips versus 34 kontroles gematched nadr leeftija, sexe, opleiding en IQ, met drie hostiliteitschalen, ontleend aan Gottschalk (1963). Hierbij worden verbale uitdrukkingen van hostilitelt gemeten. De Hips skoorden op de "Hostility inward" schaal ( similar to self-criticalness 
and self-destruction) en op de "Ambivalent Hostility" schaal (hostile expressions towards the self which are attributed to others) hoger in vergelijking tot de kontroles (resp. $\mathrm{p}=.01$ en $\mathrm{p}=.06$ ).

Siltanen e.a. rapporteren in 1975 over het in 1966 in Helsinki begonnen, prospektieve cardiovasculaire onderzoek, warbij 1326 politiemannen betrokken zijn. Uit deze onderzoekspopulatie werden 3 experimentele groepen samengestela. Groep A bestaat uit 41 mannen, die geen enkel teken of symptoom van een ischemische hartziekte vertonen en tevens gekenmerkt worden door een laag medisch risiko om een dergelijke ziekte te ontwikkelen. Groep B bestat uit 40 mannen, die geen symptomen vermelden, zoals angina pectoxis of pijnaanvallen op de borst, maax waarbij het ECG wijst op een CHz ("stille $\mathrm{CHz}^{\text {") }}$. Groep C bestaat uit 40 mannen met symptomen van angina pectoris (AP) en/of hartinfarkt en/of typische pijn op de borst en ECG-afwijkingen die duiden op een CHz.

op een Sentence Completion Test skoorde groep $\mathrm{C}$ hoger op een agressievariabele dar groep $A(p<.10$, tweezijdig). De groepen B en C skoorden hierop "nearly equal".

3.2.2. Diskussie.

Uit de beschrijwingen van de onder 3.2.1. genoemde 1iteratuur kan njet zonder meer de konklusie worden getrokken, dat bij patienten met een CHz in meer dan "normale" mate sprake is van agressiviteit. Desalniettemin komt uit het geheel van de kilinische indrukken betreffende "agressie" bij Hips bij herhaling de tendens naar voren om aan Hips kenmerken van meer dan gemidaelde agressie toe te schxijven.

Een bezwaar van het gebruik van klinische methoden is de mogelijkheid tot "hineininterpretieren" al of niet ten gevolge van elkar napraten. voorts kan als bezwar gelden, dat de bewering "meer dan nomaal" een te subjektjeve en diskutabele beoordeling is. Toch zijn via klinische methoden verkregen bevindingen niet zonder meer aan de kant te schuiven. $z$ ij verdienen minstens gewardeerd te worden als hypothesen-generexende inspiratiebron voor nader onderzaek, - bij voorkeur met behulp van eenvoudige - objektieve methoden. De konstruktie van de BuL, warvan de items immers gebaseerd zijn op kinische beschrijuingen van o.a. Hips, werd juist ter hand genomen om aan de instrumentontwikkeling in deze bij te dragen.

3.2.3. Bevindingen gebaseerd op indelingen in door de onderzoeker(s) zelf min of meer omschreven kategorieën. 
Op basis van interviewgegevens beoordeelde Gildea (1949) patienten met een cHz op "repressed hostility". Haar onderzoek leidae tot de uitspraak, dat dit kemmerk bij deze patienten in lichte mate aanwezig is.

Miles e.a. (1954) beoordeelden 46 Hips en 49 kontroles via een 5-puntsschal op "repressed vs expressed agiression". cen lage beoordelingsskore komt overeen met "never openly expressed hostility" "een hoge met "frequently angry and expressed anger openly" . De Hips behaalden een hogere beoordelingsskore dan de kontroles. opvallend is wel, dat relatief veel Hips aan zowel de "never" als aan de "frequently" kant skoren. opvallend hieraan is dus de neiging tot het vertonen van extreem tegengestelde gedragingen en het ontbreken van een duidelijke tendens in ëen bepaalde richting. Deze proefpersonen waren reeds eerder somatisch onderzocht door Gertler e.a. (1954). De groepen bestonden oorspronkelijk uit ieder 100 mannen, warvan resp. 46 Hips en 49 kontroles achterhala konden worden.

Forssman en Lindegard (1958) interviewden 62 Hips, niet ouder dan 55 jaar, 2 tot 8 jaar na hun eerste infarkt. Als kontroLes interviewden zij 62 personen overeenkomstig wat betreft leeftijd en sexe. In hun vergelijkende onderzoek gebxukten zij een kategorie: Explosivity, samengesteld ult: "low threshold of irritation, acute axousal of emotion, short duration and subsequent embarrassment" "Bij een vergeljjking van de indelingen van de Hips met die van de kontroles werd op deze kategorie geen verschil in frekwentieverdeling gevonden.

3.2.4. Diskussie.

Aan het klinische konkept "agressie" kleeft het probleem, wat daaronder moet worden vexstaan. Dit klemt des te meer, omat ook dit konsept in klinische beschrijuingen meestal niet in termen van konkreet gedrag wordt gehanteerd. Om dit kI 1 nische konsept meetbaar te maken dient het eerst op de eer of andere manier te worden geoperationajiseerd. Bij de in 3.2.3. genoemde onderzoekingen is hiertoe een poging ondernomen. De bevindingen, met behulp van deze pogingen tot operational isering van het in de klinische beschrijvingen gehanteerde begrip agressie, zjjn echter verre van eensluidend en geven een onvoldoende houvast voor het doen van gefundeerde uitspraken.

3.2.5. Bevindingen gebaseerd op vergelijkend psychologisch testgedrag, met statistische bewerkingen.

Klein en Parsons (1968) onderzochten 16 mannelijke Hips en 16 mannelijke kontroles overeenkomend in leeftid, IQ, opleiding 
ch sociale status, 0. a. met de Mood scale sorteertest van clyce, bestadnde wit 133 adjektieven (Clyde, 1963). Op de via faktorandyse verkregen "aggressive" schal skoorden de Hips in de "aggressive" richting (p) .05).

Theorell en Rahe (1972) onderzochten 62 Hips en 109 kontroles, overeenkomend in leeftijd, sexe en beroepsnivo met behulp van een rragenlijstmethode. De Hips gaven een "greater hostility at being slowed down by others" aan dan de kontroles $(p<.05)$. Siltanen e.a. (1975) rapporteerden, dat met de door hen gebruikte persoonlijkheidsvragenlijst chz-mannen op de Agressie schal meer in de Agressie richting skoorden dan de "CHz-VYije"-mannen ( $<$.10, tweezijdig; zie ook 3.2.1.).

3.2.6. Diskussie.

De uitslagen genoema onder 3.2.5. bieden het meeste houvast om tot gefundeerde uitspraken te komen, aangezien de mate van "hineininterpretieren" hier het meest gereduceerd is. vooral de geobjectiveerde resultaten van Theorell en Rahe (1972) en van Siltanen e.a. (1975) steunen de klinische indruk, dat Hips, in vergelijking tot niet-Hips, op psychologische testvaxiabelen een afwijkend gedrag vertonen en wel in de richting van meer Agressiviteit. Daarbij wordt dan wel impliclet verondersteld, dat deze variabelen geoperationaliseerd datgene dekken, wat klinici onder "agressie" verstaan. 
HOOFDSTUK 4.

DEPRESSIVITEIT BIU PATIENTEN MET EEN CORONAIRE HARTZIEKTE, EEN LITERATUUR STUDIE.

4.1. Depressiviteit bij hartpatiënten, bezien vanuit de psychosomatische literatuur.

4.1.1. Bevindingen gebaseerd op interview-, biografisch anamestische- en projektietestgegevens.

Naast de aanwezigheid van kenmerken van verhoogde agressiviteit bij CHz-patiënten wordt in vele gevallen ook de aanwezigheid van kenmerken van depressiviteit beschreven. volgens Arlow (1945) zijn deze patiënten geneigd tot het ontkennen van gevoelens van zwakheid en angst o.a. door "to carry on their business as usual from bedside". Wanneer deze vorm van ontkenning niet langer gebruikt kan worden, worden deze patiënten dikwijls depressief, "feeling that he is no longer of any account".

Dezelfde reaktie op hun ziekte beschrijft Dunbar (1948): "If activity is curtailed they become depressed and lonely". voorts vermelat $\mathrm{zij}$ hun tendens tot depressie: "Appropriately enough, these patients showed a tendency to depression and a third of them reported suicidal fantasies of long duration". Groen en van der Valk (1965) maken wat betreft zelfrapportage van deze patiënten aangaande depressiviteit het volgende onderscheid: "An admission of weakness or depression in a difficult life situation is hardly ever heard from them,.... Only after the heartattack has occured this may happen...". Berg-Larsen (1970) geeft zijn indruk aangaande patiënten tijdens de opname in een coronary care unit als volgt weer: Anxiety and depression were frequently seen...". Zijn deze mensen later op de gewone verpleegafdeling, dan signaleert de auteur ook veel angst en depressie, die hij ziet als "a result of the concommitant social demands on the traumatized patient" Cleveland en Johnson (1962) vergeleken onderzoeksgegevens betreffende de Thematic Apperception Test (TAT) van Hips met die van tbc-patienten. Zij konstateren: "The coronary TAT stories can be summarized as reflecting a generally despondent hopeless and "what is the use' attitude".

4.1.2. Diskussie.

Uit de in 4.1.1. gerefereerde 1iteratuur komt de CHz patiènt naar voren als iemand met opvallend depressieve kenmerken. Deze worden opgevat als reakties op de $\mathrm{CHz}$, of gezien als een tendens die reeds voor het ontstaan van de CHz aarwezlg was. 
Groen en van der valk (1965) laten in het midden of bij de2e patienten depressiviteit nu wel of niet anwezig is. Zij beweron alleen, dat "weakness or depression" door deze patiënten zelden openlijk tot uitarukking worden gebracht. Het probleem bif de in 4.1.1. genoemde bewindingen is weer, dat deze verkregen $z i j n$ met behulp van onderzoeksmethoden, die wetenschappelijk aanvechtbaar zijn. De invloed van de elgen insteling van de ondexzoeker evenals het theoretische kader warbinnen de onderzoeker denkt, kan het weergegeven beeld te sterk hebben gekleurd.

4.1.3. Bevindingen gebaseerd op indelingen in door de onderzoeker(s) zelf min of meer omschreven kategorieen.

onder dit hoofd is het werk van Gildea (1949) vermeldenswara. Deze rekent "Depression" tot de bij deze patienten in lichte mate aanwezige faktoren.

Weiss e.a. (1957) kwamen op grond van interviewgegevens van 43 gehospitaliseerde Hips tot de konklusie, dat in vergelijking tot 43 patiènten met andere aiagnoses,bij 23 \% van de Hips tegen 2\% van de patienten met andere diagnoses, van depressie sprake was. Aan de hand van interviewgegevens beoordeelden Forssman en Lindegard (1958) zowel coronaire patiénten als kontroles o.a. op de kategorie: periodieke depressie (zie ook 3.2.3.). Aldus vertoonden meer post-coronaire patiénten periodieke depressies dan kontroles ( $\mathrm{p}<.01$ ).

Dovenmuehle en Verwoerdt (1962) interviewden 62 patienten met een CHZ. Viexenzestig procent van deze patienten werd als middelmatig tot zeer depressief beoordeeld. Ofschoon verder niet met kwantitatieve gegevens geadstrueerd stellen zij: "The incidence of moderate and severe depression was significantly greater in the hospitalized cardiac patients than in the community subjects who were suffering from depressive symptoms". Rosen en Bibring (1966) besteedden aendacht aan de relatie tussen depressie en de leeftjj warop iemand door een hartinfarkt getroffen wordt. Op grond van o.a. beoordelingen door verplegend personel komen zij tot de veronderstelling, dat het vöorkomen van overte depressies het hoogste is bij gehospitaliseerde Hips tussen de 50 en 55 jaar.

op basis van langaurige observatie in een psychiatrisch ziekenhuis veronderstelden Dreyfuss e.a. (1969) een relatie tussen depressie en het ontwikkelen van een hartinfarkt. Om deze verondersteliling te onderzoeken gingen zij de diagnoses na van alle in het psychiatrisch ziekenhuis opgenomen patiënten van boven de 40 jaar.

In de groep met depressieve syndromen werden signifikant meex Hips aangetroffen dan in alle andere diagnose-groepen $(p=.03)$. 
In $79 \%$ van de gevallen waren depressies aan het infarkt voorafgegaan, "indicating thereby that they did not constitute a reaction to the myocardial infarction". Deze bevinding Leidae tot de vraag: ". Whether the infarct does not serve in some as an unconscious act of self-destruction..." Cay e.a. (1972) interviewden 203 patienten, nadat zij 8 tot 10 dagen ult de intensive care unit ontslagen waren. Na medisch onderzoek bleken miet alle 203 patiénten een hartinfarkt gehad te hebber. In 528 van de gevallen, die tijdens de latste opname of ooit in het verleden een hartinfarkt hadden doorgemaakt, bleek de psychiatrische diagnose "Depressie" gestela tegen 23 van de gevallen die nooit (dus ook niet tijdens de latste opname) een hartinfarkt hadden doorgemakt. Op grond van interviews met nabestaanden van 26 patiënten "who died suddenly", waarschijnlijk aan een myocardinfarkt, berichtten Green en Goldstein (1972): "From the data availam ble, via the sources available, at least 80 of these 26 patients had symptoms which could be construed as depression. They were and had been "running sad" "

4.1.4. Diskussie.

Hoewel bij de in 4.1.3. genoemae onderzoeken het begrip "depressie" strakker geoperationaliseerd is dan bij de in 4.1 .1 . beschreven onderzoeken, blijft de invloed van de onderzoeker(s) op de bevindingen niet te bepalen groot. Het is immers vooral de beoordeling van de onderzoeker die de basis vormt voor latere konklusies. Wel voeren ook de konklusles van de onderzoeker(s) tot hetzelfde punt: de samenhang van het hebben van een $\mathrm{CHZ}$ en het vertonen van depressieve kenmerken. Alvorens deze bevinding als min of meer vaststaand kan worden geaccepteerd zal zij echter eerst middels meer objektieve methoden getoetst moeten worden. Hieronder zal witeengezet worden op welke wijzen pogingen dartoe zijn ondernomen.

4.1.5. Bevindingen gebaseerd op vergelijkend psychologisch testgedragr met statistische bewerkingen.

onder dit hoofd valt een onderzoek van storment (1951). Deze onderzoeker makte ter toetsing van enkele uitspraken van Dunbar (1949, zie 4.1.1.) t.a.v. CHz-patienten gebrujk van 13 schalen van Guilford en Guilford-Martin (1943). Een van deze schalen is een Depressiewschaal. In vergelijking tot de nomgroep bleken $B$ gehospitaliseerde Hips meer in de richting van "Cheexfulness and optimism.." te skoxen, hoewel binnen het normgemidalde.

Ostfeld e.a. (1964) geven resultaten weer van een prospektieve epidemiologische studie naar het vö́rkomen van $\mathrm{CHz}$. Zij be- 
gonner hiemee in 1957/58, warbij 1990 mannen betrokken zijn, werkaam bij de Western Electric Company. Deze mannen waren tussen de 40-55 jaar en bij het eerste onderzoek vrij van klinische CHz. Na $4 \mathrm{y}$ jaar bleken er 105 uitvallers te zijn. Van de overige 1885 mannen hadden ex 50 angina pectoris (AP) ontwikkeld en 38 een hartinfarkt. Bij het beginonderzoek werd door deze mannen de Minmesota Multiphasic Personality Inventory (MMPI, Hathaway en Mckinly, 1951) ingevuld. De mannen die later een infarkt of AP zouden ontwikkelen, weken op de Depressie-schal van de MMPI niet af van de mannen die gedurende diezelfie periade CHz-vrij bleven. Vermeldensward is wel, dat de mannen met AP op 7 van de 9 kinische schalen hogere gemiddelde skores vertoonden dan de Hips" hoewel de $p$ tweezijdig per schaal $>.05$ was.

over dezelfde onderzoekspopulatie vergeleken shekelle en ostfeld (1965) gegevens van mannen die hun hartinfarkt overleefden met die van hen, die dit niet overleefden. De niet-overlevenden bleken bij het begin van het onderzoek hogex op de Depressie-schal te skoren dan de overlevenden $(.05<\mathrm{p}<.10$, tweezijaig).

Lebovits e.a. (1967) vermeldden gegevens var het 5de vervolgonderzoek bij deze onderzoekspopulatie. Er blijken dar 15 mannen aan hun eerste $\mathrm{CHZ}$ overleden te zijn. van de overige 91 CHZ-manner deden er 13 om verschillende redenen niet mee aan dit vervolgonderzoek, zodat er een groep van 27 Hips en een groep van 51 mannen met AP overbleven. Van deze in totaa 178 overlevenden vertoonden $14 \%$ een verhoogde Depressie skore bij de begin-MMPI tegen $33 \%$ van de niet-overlevenden ( $p=.03$, twee$z i j \mathrm{dig}$ ).

Brozek e.a. (1966) begonnen in 1948 een prospektief cardiovasulair onderzock. Door 258 mannen, die bij het eerste onderzoek klinisch gezond waren, werd deze MMPI ingevuld. In de daropvolgende jaren ontwikkelden hietvan 3i mannen een CHz, warvan 24 een infarkt en 7 AP. Gedurende diezelfde periode bleven 138 manner "cl.inical normal". Bij vergelijking van de Depressie skores van de latexe cHz-mannen met die van de 138 kontroles, bleken de gemiddelde skores statistisch niet signifikant te verschillen bij of $5 \%$.

Mordkoff en Rand (1968) bewerkten de MMPI-gegevens van 31 lips en 31 kontroles, individueel gelijkgemaakt voor leeftija, sexe, IQ, opleiding, beroepsnivo en socio-economische status. De Hips skoorden op de Depressie-schal gemiddeld hoger dan de kontroles (p <.01, tweezijaig). Ook op de Mood scale van clyde (1963) skoorden de Hips hoger op de Depressie-schaal dar de kontroles ( $<.05$, tweezijaig). 
De bevindingen van Klein en Parsons (1968, zie ook 3.2.5.) verkregen met dezelfde Depressie-schaal van clyde, komen hiermee overeen $(\mathrm{p}<.05)$.

Bruhn e.a. (1969) vermeldaen resultaten over een 7-jarig. longitudinal onderzoek. Bij het begin hiervan kregen zij de beschikking over 45 MMPI"s, ingevula door Hips die teminste én infarkt overleefd hadden. Voorts over 29 MMPI"s, ingevuld door personen vrij van $\mathrm{CHz}$ en overeenkomend in sexe, ras, lengte, gewicht en sociale klasse. Na 7 jaar zijn ex van de 45 Hips 17 aan een infarkt overleden. Het blijkt, dat deze 17 niet-overlevenden bij het begin van het onderzoek hoger op de Depressie-schaal skoorden dan de 38 overlevenden $(\mathrm{p}<.05$, tweezijdig). Ook in vergelijking tot de 29 kontroles skoorden de niet-overlevenden hoger op de Depressie-schal (p<.05). terwijl de overlevenden statistisch niet signifikant hoger skoorden bij $\propto 5 \%$.

Gentry e.a. (1972) onderzochten de mate van depressuiteit gedurende de eerste 5 dagen na opname in een intensive care unit. zij makten daarvoor gebruik van een Self-rating depressie-schaal van Zung (1965). Vermeld wordt, dat de Depressie skores van de Hips hoger waren dan die van de "normalen", doch lagex dan die van gehospitaliseerde patiënten met een depressieve reaktie. Voor deze uitspraken worden echter geen duidelijke kwantitatieve argumenten gegeven.

Thile1 e.a. (1973) onderzochten 50 Hips ongeveer 2 weken na opname met een modifikatie van de Depressie-schal van welsh (Dahlstrom en welsh, 1960). Hun ja-neen reakties op de diverse uitspraken van deze schal werden vergeleken met dje van een kontrole-groep "selected from volunteer patients seen for routine physical examination" en overeenkomend in leeftijd. In vergelijking tot deze kontrole-groep gaven beduldend meer Hips een antwoord in de Depressie richting (p (.001.). Voorts merken de autevrs op: "Many infarction patients stated very clearly that they had been anxious and depressed for a considerable time prior to their present hospitalisation" " Appels e.a. (1979 a) deden een onderzoek, "dat het hartinfarkt niet optreedt als een bliksemslag bij heldere hemel mar voorafgegaan wordt door een depressief ingekleurde toestand van vitale uitputting". Hieruit werden twee hypothesen afgeleid:

(1) "zij die hoog skoren op een vragenlijst, die gevoelens van vitale uitputting en depressie meet, hebben meer kans op het krijgen van een haxtinfarkt in de nabije toekomst dan zij die laag skoren op deze vragenlijst".

(2) "Personen, die vanwege klachten van mogelijk caxdiale oorsprong hun huisarts bezoeken en die hoog skoxer op een 
test, die gevoelens van vitale uitputting en depressie meet, hebben meer kans om binnen relatief korte termijn een hartinfarkt te krijgen dan zij die vanwege dezelfae kJachten hun huisarts bezoeken maar laag skoren op deze test"

On deze hypothesen te toetsen werd de zogeheten Maastrichtse Vragenlijst gekonstrueerd. Hiervoor werden in eerste instantie 63 vragen geformuleerd, waarmee men vitale uitputting en depressie dacht te kunnen meten. Om de monotonie van de vragenlijst te doorbreken werden 14 "filler items" toegevoegd. Deze vragenlijst werd voorgelegd, aan "gezonde" personen, betrokken bij een coPIH onderzoek in Rotterdam.

Deze groep kwam te bestaan uit 317 "gezonde" mannen. Voorts werd deze vragenljjst voorgelega aan personen betrokken bij het IMIR projekt ${ }^{2}$ in Rotterdam. In deze latiste studie werden patiënten betrokken die hun huisarts bezochten met:

a. recente, nieuwe of verengerde angina pectoris;

b. recente pijn of onaangenaam gevoel in de borst:

c. recente onverklaarde kortademigheld, hartkloppingen, duize-

ligheid, flauwvallen, bovenbuiksklachten;

d. recente, onverklaarde stemingsveranderingen.

Deze IMIR-groep die de vragenlijst invulde, kwam uit 415 patiënten te bestaan. Hieruit wexd een groep van 37 mannen geselekteerd, die bij het begin van de studie al. dan niet tekenen van een ischemische hartziekte mar niet van een oud of nieuw hartinfarkt vertoonden en die binnen een periode van 10 maanden of stierven aan een hartdood, of een hartinfarkt kregen, off bij wie een cardioloog een duidelijke verslechtering van de toestand van hun hart konstateerde. De antwoorden van deze 37 patiënten werden per item met die van de 317 "gezonde" mannen uit het CoPIH-projekt vergeleken (zgn. item-analyse). Hierbij bleken 40 items tussen beide groepen te diskrimineren. Deze 40 items werden tot éen schal samengevoega. Bij een vergelijking tussen beide groepen met behulp van deze schaal kwam naar voren, dat de 37 patienten, gezien de inhoud van de intems, in beduidend meerdere mate in de depressieve richting skoorden dan de 317 "gezonde" mannen (p < .0001). Deze 37 man-

1) Commissie opsporing en Preventie van Ischemische Hartziekten. Door deze commissie, behorende tot de Bedrijfsgeneeskunde, wordt bij een aantal bedrijven screeningsonderzoek verricht op het terrein var hart- en vaatziekten.

2) Imminent Myocaraial Infarction Rotterdam. Dit is een gezamenlijke studie over het dreigend hartinfarkt van het Thoraxcentrum en de afdeling huisartsengeneeskunde van de Medische Faculteit Rotterdam. 
nen skoorden op deze schaal, zij het beduidend mindex, ook hoger dan de IMIR-patienten, die bimmen 10 maanden na het begin van het onderzoek geen nieuwe coronaire eplsode doomaakten $(\mathrm{p}<.01)$. Appels e.a. $(1979$ a) zien in dewe gegevens een steun voor de beide eerder genoemde hypothesen.

4.1.6. Diskussie.

Aan de bevindingen, zoals genoemd onder $4.1 .5 . \mathrm{kan}$, in vergelijking tot die, vermeld onder 4.1 .3 . en 4.1 .1 , de meeste warde worden toegekend. Immers, de bevindingen die ondex 4.1. 5. beschreven worden, zijn verkregen met meer objektieve methoden, met name met objektief skoorbare psjohologische onderzoeksmethoden, zoals 13 schalen van een test van GujlforaMartin, de MMPI, de Mood Scale van clyde en de Mastrichtse Vragenlijst van Appels e.a.

Bij de konstruktie van deze tests werd een dusdanig gebruik gemaakt van statistische technieken dat aangenomen kan worden dat deze tests redelijk valide zijn om depressiviteit te meten. In ieder geval is ae invloed van de onderzoeker op de uitslag geminimaliseexd.

Tot welke overwegingen geven de testbevindingen aanleiding? Het onderzoek van stoment (1951) met de test van Guilford en Martin steunt geenszins de uitspraken van Dumbar (1948) met betrekking tot een verhoogde mate van depressiviteit bij cHzpatiënten.

De bevindingen van Morakoff en Rand (1968) zijn hiermee in tegenspraak, hoewel deze onderzoekers andere tests gebruikten, namelijk de MMPI en de Mood Scale van Clyde. zij vonden met beide tests wel steun voor de veronderstelling, dat er een relatie bestaat tussen CHZ en een verhoogde depressiviteit. Hiexop wijzen ook de testbevindingen van Klein en Parsons (1968), evemeens met de Mood scale van clyde, die van Thiel e.a. (1973), verkregen met een moditikatie van de Depressie-schaal van Welsh en die van Gentry e.a. (1972), verkregen net een self-rating depressie-schal. Hiarmee lijkt het gros van de klinische indrukken, zoals vermeld onder 4.1.1., gegteund. Het onderzoek van Bruhn e.a. (1969) echter geeft een aanwiyzing, dat het verband tussen depressiviteit en CHz gekompliceerder ligt. Uit hun onderzoek bijjkt, dat cHz-patiënten, die minstens éen infarkt overleefd hebben en daarna binnen 7 jaar niet sterven aan een recidief CHZ, niet meex depxessiviteit vertonen dan hun kontroles, terwijl de CHz-patienten die wel binnen 7 jaar aan een hartaood sterven, wel meer depressiviteit vertonen dan hun kontroles. Dit vexband tussen depressiviteit en veminderde overlevingskans werd ook anderszins on- 
dersteund. Bij het begin van het longitudinale onderzoek blijken de niet-overlevende cHz-patiënten meer depressiviteit te vertonen dan de overlevende CHz-patienten. Het vinden van een verhoogde depressiviteitsskore bij een groep CHz-patiënten kan dan (mede) een funktie blijken te zijn var het arrtal CHz-patierten dat binnen een bepada tijasbestek aan een recialef CHz zal overiljaen.

Dit zow dan de mogelijkheid bieden, de depressiviteitsskore van chi-patienten als recidief-prediktor met dodelijke afloop te gebruiken.

De doox Mordkoff en Rand (1968), Klein en Parsons (1968), Thiel e.a. (1973) en Gentry e.a. (1972) gevonden verhoogde depressiviteit bij CHz-patiënten kan een gevolg zijn van het doorgemakt hebben van de cHz. Ook bij de niet-overlevenden van het ondexzoek van Bruhn e.a. (1969) kan dat het geval zijr. Om in deze problemen een inzicht te krijgen zijn de prospektieve onderzoeken van Ostfeld e.a. (1964) en Brozek e.a. (1966) kruciaal. Doox hen wordt gevonden, dat een groep mannen die in de toekomst een CHz zullen ontwikkelen geen verhoogde depressiviteitsskore vertoont. Wanneer dit bij retrospektieve onderzoekingen wel gevonden wordt, kan dit opgevat worden als een gevolg van de cHz.

Een nadexe beschouwing van de gegevens van shekelle en ostfeld (1965) en Lebovits e.a. (1967) leert, dat mannen die aan hun eerste infarkt zullen overlijden, hogere depressiviteitsskores vertonen dan zij die dit niet zullen doen. Dus zowel retrospektief als prospektief wordt wat betreft het kenmerk depressiviteit hetzelfde patroon gevonden. Zo bezien lijkt een depressiviteitsschaal geen prediktieve waarde te hebben ten anzien van het ontwikkelen van een eerste cHz. zij gaat pas dan waarde krijgen, wanneer de $\mathrm{CHz}$ manifest geworden is. Hiertegenover staan de onderzoeksgegevens van Appels e.a. $(1979 \mathrm{a})$. Howel hun eerste hypothese (zie 4.1 .5$.$) niet ge-$ toetst wexd in de vorm van een longitudinal cohort onderzoek (wat de formulering wel suggereert) maar in de vorm vam een case-control studie, kan de hogere skore van de cases toch niet geinterpreteerd worden als een reaktie op het ontstaan van de CHZ. De vragenlijst werd immers ingevuld vón het optreden van de nieuwe coronair event. Dit houdt in, dat gevoeLens van vitale uitputting en depressie aan de manifestatie van de CHz zijn voorafgegaan. Ook het toetsingsresultaat van hun tweede hypothese, (zie 4.1.5.), dat wel gebaseerd is op een prospektief longitudinaal cohort onderzoek ( en daarom van groot gewicht), duidt hierop.

Uit het geheel van bovengenoemde onderzoeksresultaten kan afgeleid worden, dat er eerst meer research-gegevens nodig zijn 
alvorens te kunnen konkluderen, of een verhoogde mate vam depressiviteit, voorafgaande aan het ontstaan van een cHz, wel of niet a anwezig geacht kan worden. Hierbij vomt de vraag, wat onder depressiviteit verstaan moet worden, een probleem. Het is warschijnlijk, dat iedere depressiviteitsschall wat anders 'meet'. Zo maken de items die op vitale uitputting betrekking hebben, de Mastrichtse vragenlijst tot een andere depressiviteitsschaal dan b. v. die van de MMPI of die van de BUL, die ook op depressiviteit betrekking hebben. Een ander punt is, of depressie (en vitale witputting) als een toestand opgevat dient te worden (state-depressiveness) of als een persoonlijkheidskenmerk (trait-depressiveness). Ook hierover is meer onderzoek gewenst. 
AKTIVITEITSGRAAD EN WERKINSTELLING BIJ PATIENTEN MET EEN CORONAIRE HARTZIEKTE, EEN LITERATUURSTUDIE.

5.1. Attituden ten aarizien van werken en aktiviteit bij hartpiteitenten, bezien vanuit de psychosomatische literatuur.

5.1.1. Inleiding.

In de betreffende psychosomatische literatuur worden nogal wat lijnen getrokken ter schetsing van de werkinstelling en CHz-patiënten. Ambitie, hard werken, karrière-behoefte, veeleisendheid ten opzichte van zichzelf en een grote mate van prestatiegerichtheid zijn daarbij steeds terugkerende kenmerken. In hoeverre hierbij sprake is van het door de ene auteur overnemen van beeldvorming van de andere, is moeilijk na te gaan.

Reeds in 1910 gaf osler een beschrijving van de CHz-patiënt, waarbiy deze geschetst werd als "the keen and ambitious man" en als "whose engines is always at 'full speed ahead". Vanaf 1945 keert deze thematiek in toenemende herhaling terug in de desbetreffende literatuur, welke hiernavolgend zal worden gerefereerd.

5.1.2. Bevindingen gebaseerd op interview-, biografisch anamnestische en projektietestgegevens.

In enigszins andere bewoordingen vindt men bij Dunbar (1948) dezelfde elementen terug, die Osler in 1910 voor de CHz-patiënt beschreef. Ten aanzien van de beroepsloop van deze patienten stelt Dunbar (1948):" ...instead of starting on a career of wandering, these patients threw themselves into a life of extreme ambitious activity..". De 'full speed ahead' karakterisering van osler (1910) keert terug in: "...compulsively consistent action... tendency to work long hours and not take vacations".

Arlow (1945) typeert de werkinstelling van deze patiënten aldus:" Through hard work, self-discipline and compulsive devotion to determination of the task which he assigns to himself, the patient keeps driving himself to success ". Op grond van een vergelijking van 100 coronaire patienten met 100 kontroles, avereenkomend in leeftijd, beroepsnivo en ethnische origine, konkluderen Russek en Zohman (1958) dat "the young coronary patient was found to be an aggressive, ambitious individual who had lived beyond his normal capacity and tempo ". Cleveland en Johnson (1962) wijzen erop, dat slechts weinig coronaire patiënten in staat bleken het rustig 
aar te doen of on zich te ontspanner (zie ook 3.2.1.). Een ander geluid komt wan Bainton en peterson (1965). 21 j interviewden nabestaanden van 133 patienten met een dodelijk hartinfarkt. Zij vonden in de aldus verzamelae gegevens geen steun voor de gangbare opvatting, dat de cHz patient een zichzelf opjagend, ambitieus mens zou zijn.

Groen en Van der Valk (1965) voegen aan het beeld van de cuz patiënt een extra dimensie toe, die men als zodanig bij andere onderzoekers niet terugvindt. Deze aimensie luidt in hum eigen woorden: "The main feature of the personality, may be described as an exaggeration of otherwise rather normal behaviour patterns of the western culture of to-day".

Dit kenmerk van overdrijving menen zij ook terug te vinden in de werkinstelling van deze patienten: "Coronaxy occlusion seems to occur with greater frequency in individuals who tend to work harder than others". Zij halen dan een Amerikaanse hartinfarktpatiënt aan, die op cynische wijze "liamátschapseisen van de hartinfarktclub" formuleerde. Enkele daarvan zj.jn:

1. Your job comes first, personal considerations are secondary.

2. go to the office evening, Saturadys, Sunday and holidays.

3. take the brief-case home on the evenings when you do not go to the office.

4. if your work calls for traveliling work all day and drive allu night to make your appointment for the next morning.

Kernachtig typeren van der valk en Groen (1967) chz-patiénten dan ook als "work-addicts".

Dit is ook de teneur van beschrijvingen door kits van Heiyningen (1965) en Treurniet (1965).

Bastiaans (1968) vat de bevindingen van de Psychosomatische Werkgroep als volgt samen: "The coronary patient differs from the avexage population by a marked extroversion and by a compulsive and impulsive addiction to hard work".

Appels (1972b) noent als een van de kenmexken van chu patienten "over-aktiviteit", hetgeen een verzamelnaam is voor: eerzucht, rusteloos ongeduld, competitiezucht, agressiviteit, onvermogen zich te ontspannen en een grote sociale aktiviteit.

5.1.3. Diskussie.

In de onder 5.1.2. genoende bevindinger kan men een sterke mate van overeensteming ontdekken. Hoewel verschillend in bewoording, wijzen de beschrijuingen in het algemeen op het bestaan van een positieve relatie tussen CHz en "extreme ambitious activity". Zie voor bedenkingen, aangaande de toegepaste onderzoekingsmethoden 3.2.2. en 4.1 .2 .

Bovengenoemde globale bevindingen kunnen, hoe consistent ook, geenszins als betrouwbaar gezien worden. Wel bieden zij de 
mogelijkheid on in een later stadium hienit toetsbare hypothesen af te leiden on darna een meer gefundeera standpunt in te kunnen nemen.

5.1.4. Bevindingen gebaseerd op indelingen in door de onderzoeker(s) zelf min of meer omschrewen kategoxieën.

Als eerste valt in deze rubriek een vergelijkend onderzoek door Miles e.a. (1954) te vermelden, waarbij 46 Hips en 49 kontroles betrokken waren. van deze personen wexd nagegaan of zij vielen in de kategorie: "compulsive striving, hard-work, selfdiscipline and great need to get to the top". Naar hun beoordeling viel. $24 \%$ van de Hips en $10 \%$ van de kontroles in deze kategorie; geen indrukwekkend groepsverschil, zoals de auteurs ook zelf opmerken.

Russek en Zohman (1958) gingen na hoeveel proefpersonen uit hun coronalre groep 60 of meer uren per week hadden gewerkt en vonden: "An additional 64 g of the coronary group had worked 60 hours or more per week for long periods immediately preceeding clinical manifestations". Hoe hoog dit pexcentage voor de kontrole groep is, wordt echtex niet vermeld.

Miller (1965) vergeleek 34 Hips met 34 kontroles met als variabele: achievement-need. Hierbij werd gebruik gemaakt van een analyse methode voor verbaal gedrag, zoals ontwikikeld door Gottschalk (1963).

op deze variabele werd tussen beide groepen een verschil gevonden $(\mathrm{p}=.05)$, doch in tegengestelde richting dan verwacht. Cleveland en Johnson (1962) (zie ook 3.2.1.) lieten Hips een zelfkonsept test invullen. Nagegaan werd, op welk "statement" $2 / 3$ van de Hips hetzelfde antwoord gaf. Aan de hand hiervan stelden de onderzoekers de volgende beschrijving op: "The picture thus obtained is of a person who presents himself as success-driven and independent, but also extremely concerned with how others see him" "Een vergelijking met de kontrolegroep wordt niet vermela.

Liljefors en kahe (1970) onderzochter 47 paren zweedse identieke tweelingen tussen de 42 en 67 jaar. Voor ieder tweelungpar werden verschil-skores berekend tussen de ernst van de coronaire hartziekte (die geheel kon ontbreken) en "devotion to work", beoordeeld door 4 onafhankelijke beoordelars. Van deze 47 tweelingen bleken ex 32 een verschil-skore te vertonen voor wat betreft de exnst van de coronaire hartziekte. De verwachting was, dat naarmate deze verschil-skore groter was, ook de verschil-skore in "devotion to work" groter was. De korrelatie lag in de verwachte richting, doch $\mathrm{p}>.05$. cay e.a. (1972) (2le ook 4.1.3.) vermelden, dat van de mannen die opgenomen werden met een hartinfarkt, 82 s een "excellent 
or good work record" hadden, sos van de recidiverende Hips eveneens en van de niet-Hips daarentegen 64k. Ex worden echter geen kriteria voor "excellent or good work record" gegeven, evenmin als p-waarden.

Thiel e.a. (1973) vergeleken 50 Wips met 50 kontroles op hun gemiddeld aantal uren werken per week. Meer Hips bleken 61 uren of meer per week te werken in vergelijking tot hun gezonde kontroles ( $\mathrm{p}(.05)$. Iind en Theore11 (1973) bevestigen deze bevinding. Appels (1972a) vermeldde resultaten van een korrelatieonderzoek op epidemiologisch nivo. Hij ging ervan ult, dat patiënten met coronaire hartziekten een sterke prestatie-motivatie zouden vertonen. Op grond hiervan deed hij de voorspelling, dat het land, dat de meeste nadruk legt op prestatiemotivatie, het hoogste sterftecijter aan hart-en vatziekten moest vertonen. Aan de hand van een mat voor prestatie-moti.. vatie, ontleend aan MCClelland (1961) en tabellen wan de Wexeld Gezondheids Organisatie kwam Appels tot de konklusie, dat de gevonden korrelatie-koëficiënten erop wijzen, dat de voorspelde relatie inderdaad bestat.

\subsubsection{Diskussie.}

Bij de onder 5.1.4. genoemde onderzoeken is getracht een operationalisatie te vinden voor begrippen als over-aktiviteit, verslaving aan werken, ambitieuze instelling e.d. Die van Miles e.a. (1954) is niet verder gekomen dan de klinische omschrijvingen; de beoordelingen blijven subjektief. Dit alles makt het trekken van een konklusie moeilijk. In het onderzoek door Russek en Zohman (1958), waarbij een strengere operationalisatie gehanteerd werd (n1. 61 of meer uren werken per week) werd helaas geen vergelijking met de kontrolegroep gemaakt. Dit laatste ontbreekt ook bij het onderzoek van Cleveland en Johnson (1962). Dit makkt de intexpretatie van de gegevens moilijk. Bij Millex (1965) is de operationalisatie door relatief strenge kriteria gedetinieera. De bevinding echter is tegengesteld aan de kinische beweringen. Het tweelingenonderzoek door Liljefors en Rahe (1970) lat geen duidelijk beeld zien en bij het onderzoek door cay e.a. (1972) is de operationalisatie te onnawkeurig om de bevindingen te kunnen beoordelen. Dit in tegenstelling tot het werk van Thiel e.a. (1973) en Lind en Theorel1 (1973). Deze onderzoekers gebruikten dezelfde, goed gedefinieerde variabele: 61 of meer uren werken per week. En er werd gebruik gemaakt van een kontrolegroep. Aan hun bevindingen en aan die van Appels (1972) kan in deze de meeste waarde gehecht worden. Dit voext tot de algemene konklusie, dat ex via meer systematisch onderzoek enige steun gevonden is voor de klinfsche 
beschrijvingen.

5.1.6. Bevindingen gebaseerd op vergelijkend psychologisch testgedrag. met statistische bewerkingen.

van onderzokingen, met objektievere methoden dan gebruikt bij de onder 5.1.4. genoemde onderzoeken, valt allereerst dat van stoment (1951) te vermelden. Voor zijn onderzoek maakte hij gebruik van Faktor $G$ (Genexal Activity) van de 13 personality Factors Test van Guilford en Martin (1943). De skores van 8 cHz-patienten op de Faktor $G$ werden vergeleken met die van de normgroep. De CHZ-patiënten bleken niet afwijkend te skoren. Wardwell e.a. (1963) deden een onderzoek bij 87 mannen, die een eexste hartinfarkt hadden doorgemaakt. Als kontroles diende een groep van 435 mannen van gelijke leeftijd. Als variabele diende een vraag betrefferde "the ability of the subject to relax "after a hard day". In vergelijking tot de kontroles gaven de Hips vaker het antwoord "yes" bij de antwoordkategorie "has trouble relaxing after a hard day" $(\mathrm{p}<.001)$. Brozek e.a. (1966) gebruikten bij hun prospektieve onderzoek de Thurstone Temperament Scheaule (1950). Bij hun follow-up onderzoek bleken de 31 mannen die een cHz ontwikkeld hadden, terwijl zij voordien deze lijst hadden ingevuld, hoger te skoren op de "active"-schaal $(\mathrm{p}<.05)$. Volgens Thurstone zou een verhoogde skore op deze schaal betekenen: "that the subject is likely te be 'on the go'. He tenás to speak, walk, write, drive, work and eat fast, even when he does not have to do so".

5.1.7. Diskussie.

De onder 5.1.6. genoemde resultaten zijn uiteraard wit research oogpunt de meest valide bijdragen tot de exploratie van dit probleem gebied. In 2 van de 3 onderzoeken wordt, onafhankelijk van elkar en met verschillende operationalisaties steun gevonden voor de veronderstelling, dat ex een positieve relatie bestat tusser $\mathrm{CHz}$ en overaktiviteit, zich niet kunnen ontspannen e.a. Het prospektieve onderzoek van Brožek e.a. (1966) verleent steun aan de veronderstelling, dat dit verband reeds voor de manifestatie van de CHz aanwezig is. Op de vraag, of dit ook een oorzakelijk verband is, kan dit onderzoek uiteraard geen antwoord geven. Tot slot: opvallend is de overeenkomst tussen de bewoordingen van osler (1910) wanneer hij de cHzpatiënt schetst als degene "whose engines is always at "full speed ahead" en die van Thurstone (zie onderzoek van Brozek e.a.), wanneer hij over de hoge skoorder op de "active"-schaal spreekt: "the subject is likely to be "on the go"". 
HOOFDSTUK 6 .

SOCIABILITEIT BIJ PATIENTEN MET EEN CORONAIRE HARTZIEKTE, EEN LITERATUURSTUDIE.

6.1. Sociabiliteit bij hartpatienten, bezien vanuit de psychosomatische literatuur.

6.1.1. Bevindingen gebaseerd op interview-, biografisch anamnestische- en projektietestgegevens.

In de klinische psychosomatische literatuur betreffende CHZpatienten wordt bij herhaling gewezen op een aantal eigenschappen, samen te vatten onder de term: sociabiliteit.

Dunbar (1948) beschrijft $\mathrm{CHz}$-patiënten wat betreft hun sociale instelling als opgewekte, sociaal ingestelde mensen met de neiging tot het maken van plagerige grapjes en het zich inzetten voor andere mensen: "They are good at telling stories, do a lot of 'kidding' on the ward, and generally are cheerful. and sociable" (Dunbar, 1948).

In dezelfde lijn ligt de uitspraak van Groen en van dex valk (1965): "They seem to take a more active part in the social Iife of the community..., go to cocktail and dinner parties and are active members of societies and clubs". In de beschrijving door Treurniet (1965) komen nog andere aspekten naar voren, die het beeld van de sociale insteliing van de CHz-patient aanvulien. Hij typeert hen als "de grote verwenners en verzorgers. Zelf zijn zij zeer gesteld op warmte en gezelligheid. Hun sociale activiteit heeft vaak een bruisend, soms zelfs spuitend, joviaal karakter". Ook hij noemt hun grote 'sociability', mede bepaald door het moeilijk neen kunnen zeggen.

Siltanen e.a. (1975, zie ook 3.2.1.) komen op basis van hun bevindingen, verkregen met behulp van het onderzoek volgens Rorschach, tot een gelijkluidende konklusie. Op de variabele "Human content" skoorde de groep CHz-mannen hoger dan de groep mannen, die vrij waren van een coronaire haxtzlekte ( $\mathrm{p}<.10$, tweezijdig). Hieruit wordt door de onderzoekers afgeleid, dat cHz-mannen opvallend meer gericht zijn op kontakten met andere mensen.

6.1.2. Diskussie.

De klinische bevindingen, onder 6.1.1. genoemd, wijzen alle in dezelfde richting: CHz-patiënten zouden in meer dan gemiddelde mate sociabel zijn, namelijk in opvallend hoge mate gexicht zijn op kontakten met anderen. Enkele aspekten waarin dit tot 
uiting kont zijn: zich inzetten yoor anderen aktief deelnewen aru het gemeenschapsleven, het verwennen en verzargen van anderen, op warnte en gezeliligheid gesteld zijn, geen

'neen' kunnen zeggen, plagerige grapjes maken etc.

Aangezien het hier opnieuw klinische bevindingen betreft, zijn ook hiex weer de bezwaren var toepassing, zoals samengevat in 4.1.2.

6.1.3. Bevindingen gebaseerd op indelingen in doox de onderzoeker (s) zelf min of meer omschreven kategorieên. Onder deze rubriek vait allereerst het onderzoek te vermelden van Gildea (1949). Op grond van de onderzoeksgegevens konk Ludeert deze onderzoeker dat de kaxakteristiek "sociable, well liked" bij deze patienten in hoge mate aanwezig is.

Miles e.a. (1954, zie ook 3.2.3.) deelden hun profefpersonen in op een kontinuüm "Solitary-Soclable". Mannen met een CHz en kontroles bleken zich op ait kontinuüm niet te onderscheiden.

Van dex Valk (1960) toetste met behulp van een vragenlijst de hypothese, dat hartinfarktpatiënten meer sociale kontakten hebben dan gezonden. Geheel tegen de verwachting in bleek, dat gezonden $(n=19)$ signifikant ( $p=.01)$ meer kontakt met familieleden hadden dan hartinfarktpatiënten $(n=14)$. Evenmin werd bij een der overige in dit onderzoek gehanteerde rubrieken, te weten: social kontakt, vrienden, lid van een vereniging zijn en uitgaan, een duidelijke steun gevonden voor de juistheid van zijn hypothese.

6.1.4. Dilskussie.

Evenals bij de onder 6.1.1. gerefereerde bevindingen valt ook bij bovenstaande bevindingen op, dat zijin het algemeen in dezelide richting wijzen. De uitkomsten zijn hier echter niet in overeensteming met de verwachting. Zij verlemen $n l$. geen steun aan de klinische veronderstelling, dat cHz-patiënten in meex dan gemiddelde mate sociabel zijn, met andere woordan in opvallend hoge mate gericht zijn op kontakten met anderen.

6.1.5. Bevindingen gebaseerd op vergelijkend psychologisch testgedrag, met statistische bewerkingen.

Als een van de eerste onderzoekers die een objektief te skoren psychologische test gebruikte on klinische indrukken over CHz-patiërten te onderzoeken, kan storment (1951) genoemd worden. Hij makke daarbij gebruik van de 13 Personality Factors Test van Guilford en Martin (1943). Op faktor $s$ "social introversion versus extroversion" van deze test skoorden 
de chz-mannen méér in de extroversie-richting in vergelijking tot de normgroep, doch hun gemidaldae skore kwam niet uit boven de hoge kant van het normgemidalde. Miles e.a. (1954, zie ook 3.2.3.) makkten gebruik van 0.a. de 16 Personality Factors Test van Cattell (1957). Op faktor $\mathrm{A}$ : warm/sociable versus aloof/stiff skoorden de CHzmannen hoger in de "warm/sociable" richting dan de kontroles $(\mathrm{p}\} .05)$.

BroZek e.a. (1966) vonden bij hun prospektieve onderzoek, dat de CHZ-mannen op de S schaal (sociable) van de. Thurstone Temperament schedule (1950) niet afwijkend skoorden van de kontroles.

Finn e.a. (1966) vonden op faktor A "warm/sociable versus aloof/stiff" van de 16 Personality Factors van Cattell (1957) geen verschil (bij $\boldsymbol{\alpha}$ 5\%) tussen 63 Ierse CHz-nannen in verge1.ijking tot de Amerikaanse normgroep.

Lebovits e.a. (1967) vermeldden, dat noch de niet-overlevenden noch de hartinfarktpatiënten, noch de mannen met angina pectoris op de Sociale introversie (Si)-schal van de MMPI afwijkend skoorden in vergelijking tot de kontroles. Dit geldt voor zowel de begin MMPI als die MMPI van het 5de vervolgonderzoek. ( zie voor beschrijving van dit follow-up onderzoek 4.1.5.). De bevindingen van Bruhn e.a. (1969), die in tegenstelling tot Lebovits e.a. (1967) een retrospektief onderzoek deden, komen hiermee overeen. Zowel de overlevenden als de niet-overlevenden skoorden op dezelfde si-schaal van de MMPI bij het begin van hun projekt niet afwijkend van de kontroles. Zowel bij de afsluiting van hun projekt als bij het vervolgonderzoek 2 jaar later skoorden de overlevenden op de Si-schall niet afwijkend van de kontroles.

Siltanen e.a. (1975, zie ook 3.2.1.) vonden, dat de groep manifeste CHz-mannen op de variabele "Sociability" van de Finse Personallty Inventory hoger skoorden dan de groep mannen met een "stille" $\mathrm{CHZ}$ ( $\mathrm{p}<.10$, tweezijdig). De CHZ-mannen skoorden ook hoger dan de mannen zonder eer $\mathrm{CHz}(\mathrm{p}) .10$, tweezijaig). ook op de variabele "people orientation" van de self-concept Inventory skoorden de CHZ-mannen hoger dan de mannen met een "stille" $\mathrm{CHz}(\mathrm{p}=.01$, tweezijdig). De CHz-mannen en de CHzvrije mannen skoorden vrijwel gelijk.

6.1.6. Diskussie.

Door de gegevens van de in 6.1.5. genoemde onderzoekingen gezamenlijk en in onderlinge vergelijking te bezien is na te gaan in hoeverre deze diverse bevindingen enige algemene konklusie toelaten. 
Het onderzoek van storment (1951) met de 13 Personality Factors Test verleent geen overtuigende steun an de klinische veronderstelling, dat CHz-patiënten gekenmerkt zouden worden door een verhoogde mate van sociabiliteit. De gegevens van Miles e.a. (1954) ondersteunen de juistheid van de kinische observaties. Dit kan weer niet gezegd worden van de gegevens van Finn e.a. (1966), die dezelfde test (16 Personality Factors) als Miles e.a. (1954) gebruikten. Als komplicerende faktor kan hier gelden, dat bij het onderzoek van finn e.a. (1966) de skores van Ierse mannen vergeleKen werden net de van Amerikaanse, zodat kulturele faktoren hier allicht als confounding factors de onderzoeksxesultaten kunnen Mebben vertroebeld.

Met weer een andere test werkten BroZek e.a. (1966), de Thurstone Temperament Schedule. zij vonden met deze test geen steun voor de klinische observaties.

Consistent $z i j n$ de bevindingen van het prospektieve onderzoek door Lebovits e.a. (1967) en het retrospektieve van Bruhn e.a. (1969), die de MMPI gebruikten bij hun onderzoekingen. In beide gevalien werd geen steun gevonden voor de klinische veronderstellingen. Hetzelfae kan gezega worden aan de hana van de gegevens van Siltanen e.a. (1975), met weer andere tests.

Het geheel van de gegevens overziende kan gekonkludeerd worden, dat daar waar gepoogd is klinische bevindingen met objektieve onderzoeksgegevens te onderbouwen, de resultaten in de meeste gevallen geen steun verlenen aan de klinische observaties.

Het blijft witeraard de vraag, of de gebruikte objektief te skoren tests datgene meten wat de klinische rapporteurs met sociabiliteit bedoelen. Wel kan verondersteld worden, dat het gebruik van verschiliende tests het aantal raakvlakken met het klinische begrip: sociabiliteit, zal. doen toenemen. Juist het feit, dat met behulp van verschillende tests in het algemeen geen steun gevonden kon worden, trekt de juistheid van de klinische observatie, dat cHz-patienten een verhoogde mate van sociabiliteit vertonen, in twijfel. 
BEROEPSVERANTWOORDELIJKHEID BIJ PATIENTEN MET EEN CORONAIRE HARTZIEKTE, EEN LITERATUURSTUDIE.

7.1 Beroepsverantwoordelijkheid bij hartpatiënten, bezien vanuit de psychosomatische literatuur.

7.1.1. Bevindingen gebaseerd op interview-, biografisch anamnestischeen projektietestgegevens.

In de rij van kenmerken, die in de psychosomatische li.teratuur aan CHz-patiënten worden toegeschreven, mag het kenmerk "(beroeps) verantwoordelijkheid" niet ontbreken.

Dunbar (1948) signaleert het onvermogen of althans de moeite die deze patiënten hebben met het delen van verantwoordelijkheid met anderen en hun grote verantwoordelijkheidsgevoel in het algemeen: "In general they had a keen sense of responsibility...". Bainton en Peterson (1963) komen daarentegen tot de konklusie, dat "The populax conception of the person prone to coronary heartaisease.... in a position of responsibility could not be corroborated".

In hun overzichtsartikel attenderen Kessel en Munro (1964) op de onderhavige karakteristiek van CHz-patiënten, die zij samenvatten als: ". frequently overburdened by responsibility at. cares of office". Ook Groen en van der Valk (1965) konstateren dat: "Work seems to be very deeply involved in the patient's sense of duty and conscience". Ten aanzien van de bijzondere betekenis van de beroepsverantwoordelijkheid voor CHZ-patiënten stellen zij, dat "..most of the patients like to be in jobs were they have responsibility of their. own and can take decisions". Appels (1972) meent de bevindingen betreffende hartinfarktpatiënten uit de psychosomatische literatuur te kumnen reduceren tot 2 grondkenmerken, waarvan his ex ển aIs "zelf-kontrole" betitelt. Onder deze zelf-kontrole rekent hij met name ook "verantwoordelijkheidsgevoel".

7.1.2. Diskussie.

In het bovenstaande worden meer pro's dan kontra's gevonden voor de veronderstelling, dat cHz-patiënter gekenmerkt worden door een van de norm afwijkende mate van verhoogd verantwoordelijksgevoel, met name tot uiting komende in beroep en werksituatie. Deze klinische observaties betreffende beroepsverantwoordelijkheid kunnen uiteraard alleen via onderzoekingen met behulp van meer objektieve methoden op hun juistheid worden getoetst. 
7.1.3. Bevindingen gebaseerd op indelingen in door de onderzoeker (s) zelf min of meer omschreven kategorieen.

Russek en Zohman (1958) gebruikten bij hun beoordeling de kategorie: beroepsmatige "stress and strain". In deze kategorie vond $91 \%$ van de coronaire patiënten tegen $20 \%$ van de kontroles hun plats. Zij komen onder andere tot de uitspraak: "Consequently, it would appeax that undue emotional strain associated with job-responsibility is far more significant in the etiologic picture of coronary disease than heredity or a prodigiously high fat diet".

Kasanen e.a. (1963) interviewden 100 gehospitaliseerde hartinfarktpatiénten en 100 kontroles overeenkomende in leeftijd en opgenomen wegens een akute ziekte. In hun kategorie: "intellectual workers" kwamen relatief meer hartinfarktpatienten voor. Ditzelfde geldt voor een kategorie: "manegerial status". op basis van deze overigens niet statistisch bewerkte interviewgegevens komen zij tot de uitspraak: "This would seem to indicate that sedentary workers and persons in a responsible position have higher incidence of myocardial infarction". Caffrey (1968) trachtte de A/B- typologie van Rosenman en Friedman (zie hoofastuk 12) te verifieren door middel van een vergelijkend onderzoek tussen Bendictijner-en Trappistenmonniken in Noord-Amerika. Quinlan e.a. (1966) hadden nl. gevonden. dat Benedictijnerpriesters de hoogste prevalentie-ratio voor hartinfarkt vertoonden, vergeleken met Benedictijnerbroeders, Trappistenpriesters en -broeders. Theoretisch bezien moesten de zgr. A-type kenmerken (coronary-proneness) bij de Benedictijnerpriesters dan het sterkst aantoonbaar zijn. Ter toetsing van deze hypothese makkte Caffrey (1969, 1970) gebruik van 36 variabelen, die na faktor-analyse tot 5 faktoren gereduceerd werden. Eén ervan werd als "responsibility" betiteld. Geheel volgens verwachting vertoonden de Benedictijnexpriesters hogere skores op deze verantwoordelijkheidsfaktor dan de overige 3 monnikengroepen $(p<.05)$.

Thiel e.a. (1973) beoordeelden een groep hartinfarktpatiënten en hun kontroles op "level of occupational responsiblity". Tegengesteld aan de verwachting toonden 68 van de gezonde kontroles tegen 30 : van de infarktpatienten een "top-level of occupational responsibility".

7.1 .4$. Diskussie.

ook bij de onder 7.1.3. vermelde onderzoekingen worden meer pro's dan kontra's gevonden voor de veronderstelling, dat $\mathrm{CHz}-$ patienten gekenmerkt worden door een hoge mate van beroepsverantwoordelijkheid. Het onderzoek van Thilel e.a. (1973) laat 
zien, dat men met het aanmemen van de juistheid van deze veronderstelling toch voorzichtig moet zijn. Ook in ait geval is onderzoek met meer objektieve methoden noodzakelijk.

7.1.5. Bevindingen gebaseerd op vergelijkend psychologisch testgedrag, met statistische bewerkingen.

In deze rubriek zijn twee onderzoekingen te vermelden. Bij beide onderzoekingen werd van een vragenlijst gebruik gemakt.

In het eerste van de California Personality Inventory lGough, 1957). Deze werd door Jenkins e.a. (1969) voorgelegd aan 64 brandweerlieden. Gezien het bij vele onderzokingen gevonden verband tussen een verhoogd cholesterolgehalte en CHz (Groen, 1967) is het interessant het resultaat te weten van de skoring op de "responsibility"-schal van deze persoonlijkheidsvragenlijst en het cholesterolgehalte van deze brandweerlieden. Dit verband bleek positief ( $p<.05$ ). Hoe hoger de skore op deze schal, hoe hoger het cholesterolgehalte. Blj het tweede onderzoek werden door Theorel1 en Rahe (1972) 62 mannen met een eerste hartinfarkt met behulp van een vragenlijst onderzocht. In deze lijst werd o.a. gevraagd naar "responsibility at work". Als kontroles dienden 109 mannen, die echter niet geheel overeenkwamen in beroepsnivo en voorts jonger waren dan de infarktpatiënten. Tegen de verwachting in gaven meer kontroles $(\mathrm{p}<.05)$ "great responsibility at work" aan dan patienten.

7.1.6. Diskussie.

Hoewel in het onderzoek door Jenkins e.a. (1969) geen relatie onderzocht werd tussen CHz en psychologische testvariabelen, duidt de uitslag toch op het belang om in deze richting verder te zoeken. Dit kan weer niet gezegd worden van de uitslag van het onderzoek door Theore11 en Rahe (1972), die in hun onderzoek de rellatie cHz en de testvariabele beroepsverantwoordelijkheid direkter onderzochten. Het gegeven echtex, at de kontrolegroep kwa beroepsnivo en leeftija niet overeenkwam met de patientengroep makt hun onverwachte bevindingen echter minder solide. Al met al kan gesteld worden geen duidelijke aanwijzingen gevonden te hebben voor het wel of niet aanwezig zijn van een relatie tussen CHz en (beroeps)verantwoordelijkheid. zolang dit niet duidelijk is blijft een verder zoeken in deze richting zinvol.

In het volgende hoofastuk zullen dan ook toetsbaar geachte hypothesen geform leerd worden betreffende deze relatie. ook zullen daar toetsbaar geachte hypothesen afgeleid worden uit de klinische indrukken, zoals vermeld in de hoofastukken $3 t / m 6$. 
OPERATIONAL ISERING VAN KLINISCHE GEGEVENS TOT TOETSBARE HYPOTHESEN.

8.1. Inleiding.

In 1.2. Werd uiteengezet, dat het doel van het onderhavige ondexzoek is, het toetsen van de hypothese, dat personen met een specifiek ziektebeeld zich op bepalde psychologische onderzoeksvarlabelen onderscheiden van personen, die niet aan dat specifleke ziektebeeld lijden. Deze hypothese werd afgeleid uit een onderdeel wan een veel meer omvattende hypothese, die door medewerkexs van de Psychosomatische werkgroep onder leiding van Dr. J. Groen in 1950 aangeduid werd als de hypothese der Psychosomatische Specificiteit. Deze hypothese wordt hier echter eerder opgevat als een uitgebreid onderzoeksprograma dan als een op zich toetsbare hypothese, reden waarom een nieuwe hypothese hieruit diende te worden afgeleid.

In 1.3. werd gesteld, dat de toetsing van de voor het onderhavige onderzoek geformuleerde hypothese zou geschieden aan de hand van bepald onderzoeksmaterial, ontleend aan mannelijke hartunfarktpatiënten. De resultaten daarvan zouden dan vergeleken worden met die van "gezonde" mannen, mannen met astma bronchiale en mannen met medische diagnoses anders dan hartinfarkt en astma. Als onderzoeksvaxiabelen zouden psychologische testvariabelen dienen, zoals beschreven in hoofdstuk 2. Daarbij kwam de vraag naar voren, welke psychologische testvariabelen voor het gestelde doel relevant zouden zijn. Gezien eerdere ervaringen ging de voorkeur uit naar het zo dicht mogelijk blifven bij de klinische indrukken van hartinfarktpatiënten en astmatici.

ut kin isch-psychologische beschrijvingen van hartinfarktpatienten en astmatici door verschillende onderzoekers werden 69 psychologische testitems gegenereexd. Een faktoranalyse Iiet zien, dat deze 69 items, arangevuld met de variabelen leeftijd en opleiding, tot 6 interpreteerbare variabelen (Faktoren) gereduceerd konden worden.

Van deze aldus geëxtraheerde 6 faktoren wordt Faktor IV echter voor het onderhavige onderzoek niet geschikt geacht op grond van de hoge ladingen van de variabelen leeftija en opleiding $(21$. 2.3 .5$.$) .$

De resterende 5 faktoren worden, gezien de bron van herkomst van de items, dan ook relevant geacht voor het beoogde toetsingsonderzoek. Immers, de 5 faktoren kunnen beschouwd worden als persoonlijkheidskenmerken die als 5 "rode araden" door de 
klinische indrukken heenlopen. Door het resultat van de faktoranalyse zijn de klinische indrukken in 5 rubrieken onder te brengen: Agressiviteit, Depressiviteit, Aktiviteit en werken, Sociabiliteit en Beroepsverantwoordelijkheid ( zie de hoofdstukken $3 \mathrm{t} / \mathrm{m} 7$ ).

Uit de algemene trend van de klinisclue bevindingen betreffenoe elk der 5 rubrieken zullen hieronder toetsbaax geachte hypothesen afgeleid worden. Deze hypothesen worden toetsbar geacht met behulp van de 5 BUL-faktoren, wartoe de klinjsche bevindingen, volgens en statistische faktoranalytische techniek, gereduceerd konden worden. Deze hypothesen worden dan opgevat als "verbijzonderingen" van de hypothese dey psychom somatische specificiteit.

8.2. Afleiding van toetsbare hypothesen.

8.2.1. Hypothese betreffende agressiviteit bij hartinfarktpatiènten. In 3.2.2. werd tot de konklusie gekomen, dat uit het geheel van de klinische indrukken betreffende agressiviteit bij hartinfarktpatiënten bij herhaling de tendens naar voren komt om aan deze patiënten kenmerken van meex dan gemiddelde "agressie" toe te schrijuen.

Een nadex onderzoek van deze indrukken lijkt mogelijk met behulp van BUL-Faktor I (BF-I): Agressiviteit genaamd. De gedachtengang is, dat als de klinische indrukken juist zijn, hartinfarktpatienten bij de uitspraken die op deze "agressiviteit" betrekking hebben mér "agressiviteit" aangeven dan gezonden. Dit leidt tot:

Hypothese 1. Mannelijke hartinfarktpatiënten vertonen meer "agressiviteit" bij het beoordelen van uitspraken die daar betrekking op hebben, dan "gezonde" mannen.

8.2.2. Hypothese betreffende depressiviteit bij hartinarktpatienten. Bij de klinische indrukken betreffende depressiviteit bij hartinfarktpatiënten (zie 4.1.1.) laten Groen en van der Valk (1965) de mogelijkheid open of deze patiênten als meer dan gemiddela depressief zijn te beschouwen. Uit de rest van de in 4.1.1. gerefereerde literatuur echter kont de CHz-patient wel. naar voren als iemand met duidelijk depressieve kenmerken. Dit leidt tot de verondersteling, dat hartinfarktpatienten als meer dan gemiddeld depressief beschouwd kunnen worden. Voor een nader onderzoek van deze verondersteling biedt het gebruik van BUL-Faktor II (BF-II): Depressiviteit genaamd, een mogelijkheid. De gedachtengang is, dat als de klinische indrukken juist zijn, hartinfarktpatienten bij de uitspraken 
die op "depressiviteit" betrekking hebben, mér "depressiviteit:" aangeven dan gezonden. Dit voert tot:

Hypothese 2. Mannelijke hartinfarktpatienten vertonen mér "depressivitelt" bij het beoordelen van uitspraKen die daar betrekking op hebben, dan "gezonde" mannen.

8.2.3. Hypothesen betreffende aktiviteit en werkinstelling bij hartinfarktpatiënten.

In 5.1.3. werd gekonkludeerd, dat de klinische bevindingen in het algemeen wjzen op het bestaan van een positieve relatie tussen CHZ en "extreme ambitious activity". Een nadex onderzoek van deze indrukken lijkt mogelijk via BUL-Faktor III (BF-III): Aktivitelt en werken genaamd. De gedachtengang is, dat als de klinische indrukken juist zijn, hartinfarktpatiënten bij de uitspraken die op "aktiviteit en werken" betrekking hebben een hogere positieve waardering vertonen dan gezonden. Hieruit wordt afgeleid:

Hypothese 3. Mannelijke hartinfarktpatienten vertonen meer positieve wardering bij het beoordelen van uitspraken die op "aktiviteit en werken" betrekking hebben ,dan "gezonde" mannen.

Om tot een nadere specifikatie van de in hypothese 3 vervatte verwachting te komen, lijkt ook een vergelijking van hartinfarktpatienten met astmatici een mogelijkheid te bieden. In de betreffende psychosomatische literatuur wordt bij herhaling vermeld, dat de instelling van astmatici ten opzichte van hun werk eerder minder dan meer positief is dan gemiddeld. In dit verband signaleert Groen (1950) in een psychosomatische monografie over astmatici:"Sommige zijn harde werkers...... Andere patienten echter waren lui, kennelijk omdat hun werk hen niet aanstond". Bastiaans en Groen (1954) vermeldaen kenmerken van 1ijders aan verschillende door hen als psychosomatisch geachte organische ziekten. Ten aanien van lijders aan astma zijn zij van mening, dat deze "by outbursts" aktief zijn. Van der Valk (1960) deed een onderzoek, waarbij met behulp van een vragenlijst gegevens verzameld werden van astmatici, hartinfarktpatienten en "gezonden". Eên van de vragen betrof de houding ten aanzien van het werk. Bij een vergelijking van de antwoorden op deze vraag bleek, dat relatief meer hartinfarktpatiënten dan astmatici positief tegenover hun werk stonden (p $<.001)$. Het bovenstaande voert tot:

Hypothese 4 . Mannelijke hartinfarktpatienten vertonen een hogere positieve wardering bij het beoordelen van uitspraken die op "aktiviteit en werken" betrekking hebben, dan mannelijke astmatici. 
8.2.4. Hypothesen betreffende sociabiliteit bij hartinfarktpatiënten.

Op grond van de in 6.1.1. genoemde klinische indrukken betreffende de sociale instelling van hartinfarktpatiënten wordt in 6.1.2. gesteld, dat deze patiënten in meer dan gemiddelde mate sociabel zijn, in de zin van: in opvallend hoge mate gericht zijin op kontakten met anderen. Een nader onderzoek van deze klinische veronderstelling lijkt goed mogelijk met behulp van BUL-Faktor $V(B F-V)$ : Sociabiliteit genaamd. De gedachtengang is dan, dat als de klinische indrukken julst zijn, hartinfarktpatiënten bij uitspraken die op "sociabiliteit" betrekking hebben méer "sociabiliteit" aangeven dan gezonden. Dit leidt tot:

Hypothese 5. Mannelijke hartinfarktpatienten waarderen uitspraken die op "gesteld zijn op omgang met mensen" be-trekking hebben, positiever dan "gezonde" mannen.

ook wat betreft de veronderstelde karakteristieke sociabiliteit van hartinfarktpatiënten is een vergelijking van deze patiënten met astmatici additioneel te gebruiken. In tegenstelling tot de klinische observaties bij hartinfarktpatiënten worden astmatici in de betreffende psychosomatische literatuur namelijk getypeerd als eerder minder dan meer dan gemiddeld gesteld op kontakten met anderen. zo schrijft Groen (1950): "Dominerend in hun karakter is verder een sterke egocentriciteit. In vele gevallen is dit reeds bij oppervlakkige kennismaking met de patiënt duidelijk, max vaak wordt de egocentriciteit bedekt onder correcte omgangsvormen, onder quasi-sociale belangsteliing, zorg voor de familie, of het werk". Van der Valk (1960) vat de door Groen (1950) en Bastiaans en Groen (1954) beschreven "trekken" van zowel astmatici als hartinfarktpatiënten samen en komt vergelijkenderwijs tot de verwachting, dat astmatici minder interesse in gemeenschapsaktiviteiten zullen hebben, minder kontakt met vrienden en minder vrienden zullen hebben. Bij zijn onderzoek vond hij bij de rubriek "contact with relatives" voor hartirfarktpatiënten, in vergelijking tot astmatici, een lichte trend in de voorspelde richting, bij de rubriek "social contact", een duidelijke steun, evenals bij de rubriek "Friends" ( $\mathbf{<} .001)$. op basis van bovenstaande gegevens is te verwachten, dat hartinfarktpatiënten, in vergelijking tot astmatici, uitspraken die betrekking hebben op "gesteld zijn op omgang met mensen" anders beoordelen en wel in de richting van in meerdere mate hicrop gesteld zijn. Dit leiłt tot:

Hypothese 6. Marmelijke hartinfarktpatienten wardexen uitspraken die op "gesteld zijn op omgang met mens- 
en" betrekking hebben, positiever dan mannelijke astmatici.

3.2.5. Hypothesen betreffende beroepsverantwoordelijkheid bij hartinfarktpatiënten.

Wat betreft beroepsverantwoordelijkheid bij cHz-patiënten kon in 7.1.2. gekonstateerd worden, dat er in de psychosomatische Iteratuur bij herhaling op wordt gewezen, dat dit kenmerk in sterke mate bij deze patiënten aanwezig is. Een nader onderzoek hierover lijkt mogelijk met behulp van BUL-Faktor VI (BF-VI) : Beroepsverantwoordelijkheid genaamd. De gedachtengang is dan, dat als de klinische indrukken juist zijn, hartinfarktpatiënten bij uitspraken die op beroepsverantwoordelijkheid"betrekking hebben een andere beoordeling geven en wel in de richting van méér" bexaepsverantwoordelijkheid"' dan gezonden. Hieruit volgt:

Hypothese 7. Mannelijke hartinfarktpatiënten waarderen uitspraken die op "beroepsverantwoordelijkheid" betrekking hebben positiever dan "gezonde" mannen.

Aangezien in de betreffende psychosomatische literatuur (Groen, 1950; Bastiaans en Groen, 1954; van der Valk, 1960) geen aanwijzingen zijn te vinden voor de veronderstelling, dat astmaticl gekenmerkt worden door een hoge mate van beroepsverantwoordelijkheid, kan ook in dit opzicht een vergelijking tussen hartinfarktpatiënten en astmatici additionele steun verlenen aan de veronderstelling, dat dit voor hartinfarktpatiënten wél opgaat. Hieruit volgt:

Hypothese 8 . Mannelijke hartinfarktpatiënten warderen uitspraken die op "beroepsverantwoordelijkheid" betrekking hebben, positiever dan mannelijke astmatici.

8.3. Afsluitende opmerkingen.

Met het toetsbaar maken van deze 8 hypothesen worden in principe ook de klinische bevindingen, waarvan deze hypothesen zijn afgeleid, voor empirische toetsing toegankelijk gemaakt. op zich kunnen deze hypothesen als evenzovele verbijzonderingen worden beschouwd van de algemene hypothese der Psychosomatische Specificiteit (Groen e.a. 1965; Alexander en French, 1948). Dit betekent, dat afhankelijk van de al of niet door de onderzoeksresultaten verleende steun aan deze deelhypothesen evenzovele partièle steun via dezelfde onderzoeksresultaten kan worden verkxegen ten aanzien van die algemene hypothese der Psychosomatische Specificiteit. 
Nadat hiernavolgend op de toetsing van de afwondexijke hypothesen zal zijn ingegaan zal vervolgens op de konsekwenties darvor voor deze algemene hypothese betreffende psychosomatische specificiteit nader worden ingegaan. 
HET TOETSINGSONDERZOEK.

9.1. Samenstelling van de experimentele-en kontrolegroepen en herkomst van de proefpersonen.

9.1.1. De experimentele groep van hartinfarktpatiënten.

om de in het vorige hoofdstuk gestelde hypothesen te toretsen werd gebruik gemaakt van BuL-protokollen, ingevuld door 102 mannen, die in het verleden een hartinfarkt hadden doorgemakkt en die tijdens het invulien van deze lijst niet in een ziekenhuis of elders opgenomen waren (groep Hips-1).

Deze experimentele groep Hips-1 werd samengesteld op grond van de volgende kriteria:

a. Het ECG moest dujdelijk wijzen op een hartinfarkt;

b. Het enzymonderzoek moest duidelijk wijzen op een infarkt;

c. De anamnese moest duidelijk wijzen op een infarkt.

Aan de hand van deze kriteria selekteerden artsen/beoordelaars de proefpersonen die tot de groep Hips-1 zouden gaan behoren. De BUL-protokollen van deze proefgroep konden verzameld worden dankzij de medewerking van huisartsen en bedrijfsartsen en voorts door psychologen, werkzaam bij hartrevalidatie-centra (zie voor nadere gegevens over deze groep Hips-1 tabel 9.1. en 9.2.$)$.

9.1.2. De kontrolegroep van gezonden.

De "gezonde" kontrolegroep werd volgens een bepaalde procedure uit de grote groep van ruim 1300 mannen (zie 2.2.) samengesteld. En wel als volgt: voor iedere hartinfarktpatiënt werd naar een man gezocht met

a. dezelfde leeftijd;

b. hetzelfde opleidingsnivo.

Kwamen daarvoor meerdere mannen in aanmerking, dan werd er aselekt én uitgekozen. Niet in alle gevallen kon er een "gezonde" man gevonden worden, die aan zowel a. en b. voldeed. Dit blijkt uit tabel 9.2., waarin gegevens over leeftijd en opleiding snivo te vinden zijn.

9.1.3. De kontrolegroep van astuapatiënten.

Voor de samenstelling van een kontrolegroep, bestaande uit astmatische mannen was een kriterium: de medisch vastgestelde diagnose astma bronchiale, met symptomen van een "aanvalsgewijze optredende of verergerende kortademigheid" (Groen, 1950). Tussen 1966-1972 werd de BUL ingevuld door een aantal mannen, die volgens de artsen aan het gestelde kriterium voldeden en 


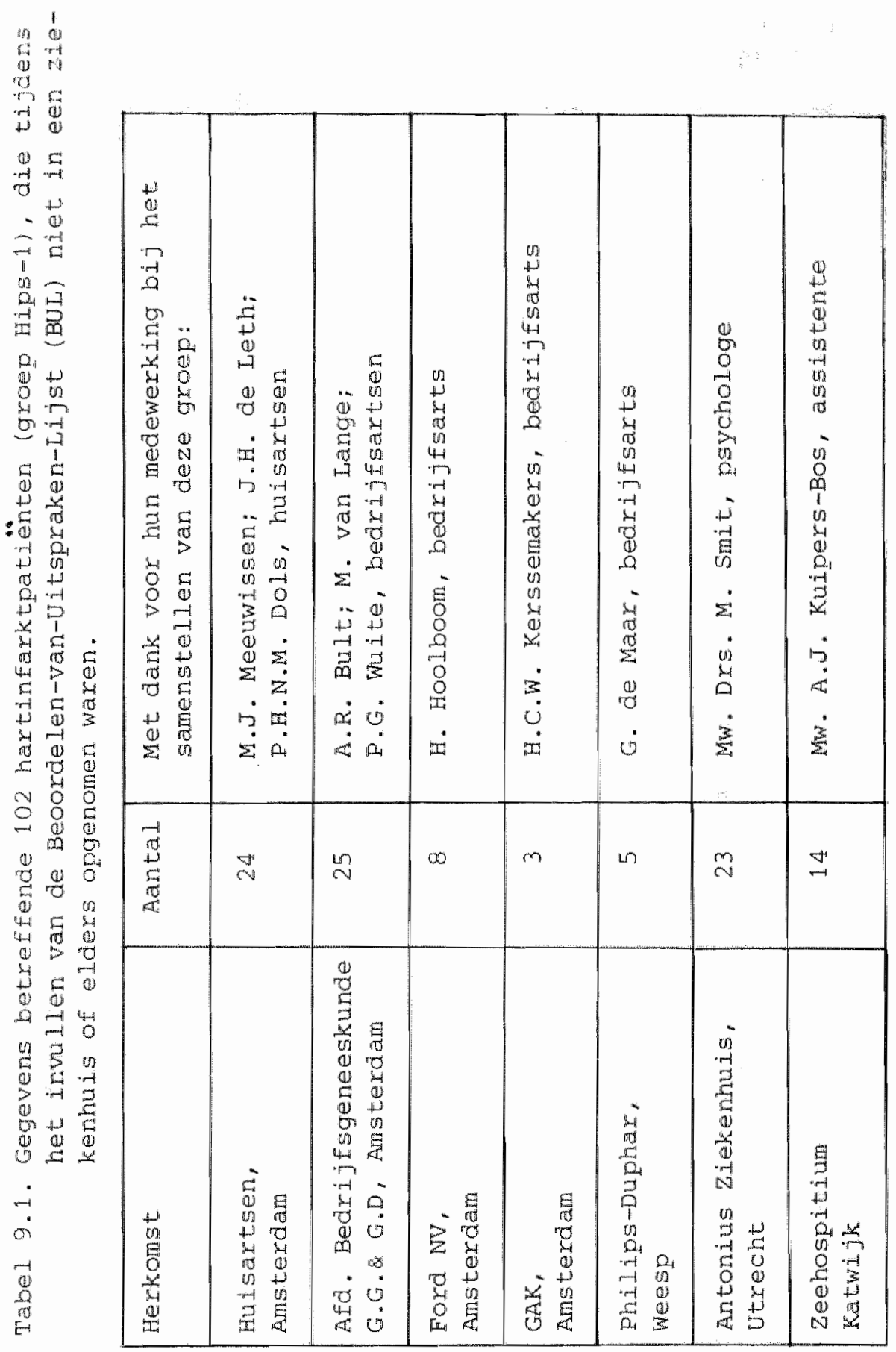


die darrvor op een polikliniek behandeld werden. vijftig van deze mannen kwamen kwa leeftijd en opleidingsnivo zo goed mogelijk net die van de 102 hartinfarktpatienten overeen.

zij vomen de groep Astma-1. (zie tabel 9.2. en 9.3.)

Tabe1 9.2. Gegevens betreffende leeftijd en opleidingsnivo van 102 "gezonde" mannen (groep Gezonden-1), 102 hartinfarktpatiêten (groep Hips-1), en 50 mannelijke astmatici (groep Astma-1).

\begin{tabular}{|c|c|c|c|c|c|}
\hline \multirow[t]{2}{*}{ Groep } & \multicolumn{2}{|c|}{ Leeftija } & \multicolumn{3}{|c|}{ Opleidingsnivo } \\
\hline & Gemidaeld & $S D$ & I & II & III \\
\hline Gezonden-1 & $51.5 \mathrm{jr}$ & $6,6 \mathrm{jr}$ & $\mathrm{n}=55$ & $n=32$ & $n=15$ \\
\hline Hi.ps -1 & 52,2 jr & $6,7 \mathrm{jr}$ & $\mathrm{n}=54$ & $\mathrm{n}=33$ & $n=15$ \\
\hline Astma-1 & 49,3 jr & $9,1 j r$ & $n=39$ & $n=9$ & $n=2$ \\
\hline
\end{tabular}

Opleidingsrivo:

I. LS, LTS of ekwivalent

I MULO, MAVO of ekwivalent

III HBS, HAVO $t / m$ Universiteit of ekwivalent

Tabel 9.3. Gegevens betreffende 50 mannelijke astmatici (groep Astma-1) die tijdens het invulien van de Beoordelem-van-Uitsprakenlijst (BUL) niet in een ziekenhuis of elders opgenomen. waren.

\begin{tabular}{|c|c|c|}
\hline Elerkomst & Aántal & $\begin{array}{l}\text { Met dank voor hun medewerking bij } \\
\text { het samenstellen van deze groep: }\end{array}$ \\
\hline $\begin{array}{l}\text { Polikjindek Pav. } 5 \text {, } \\
\text { Wilhelmina Gasthuis } \\
\text { Amsterdam }\end{array}$ & 4 & $\begin{array}{l}\text { J. Herderscheé } \\
\text { longarts }\end{array}$ \\
\hline $\begin{array}{l}\text { Ansteramse Kliniek } \\
\text { voor Allergische Ziekten } \\
\text { Amsterdam }\end{array}$ & 40 & $\begin{array}{l}\text { Dr.W.J.F. v.d. Bijl; } \\
\text { P.J.F. V.d. Werff; } \\
\text { Iongartsen }\end{array}$ \\
\hline $\begin{array}{l}\text { Polikliniek Longziekten } \\
\text { Akademisch ziekenhuis } \\
\text { Leiden }\end{array}$ & 6 & $\begin{array}{l}\text { P.H. Vooren; } \\
\text { longarts }\end{array}$ \\
\hline
\end{tabular}


9.2. Voorspellingen.

9.2.1. De onderzoeksvaxiabelen.

In hoofdstuk 8 werd voor elk der vijf genoende persoonlijkheidskemmerken uiteengezet, welke BUL-Faktor (BF) geschikt geacht werd ter meting van dat kenmerk. voor de toetsing van hypothese 1 zal dan ook gebruik gemaakt worden van BF-I (Agressiviteit), voor de toetsing van hypothese 2 van BF-II (Depressiviteit), voor de toetsing van hypothesen 3 en 4 van BF-III

(Aktiviteit en werken), voor de toetsing van hypothesen 5 en 6 van BF-V (Sociabiliteit) en voor de toetsing van hypothesen 7 en 8 van BF-VI (Beroepsvexantwoordelijkheid).

9.2.2. Konkrete voorspellingen ten aanzien van de onderzoeksvariabelen Ten aanzien van de in 9.1. beschreven groepen proefpersonen zijn uit de in hoofdstuk 8 gestelde hypothesen de volgende voorspellingen af te leiden:

Voorspelling 1. De groep Hips-1 vertoont in vergelijiking tot de groep Gezonden-1 hogere BE-I skores.

(N.B. Skores op $B F-I$ kunnen van zowel een negatief als positief teken voorzien zijn. Een relatief hoge skore op BF-I korrespondeert inhoudelijk met meér "agressiviteit".)

Voorspelling 2. De groep Hips-1 vertoont in vergelijking tot de groep Gezonden-1 lagere BF-II skores.

(N.B. Skores op BF-II zijn altijd van een positief teken voorzien. Een relatief lage skore op BF-II korrespondeert inhoudelijk met meér "depressiviteit".)

Voorspelling 3. De groep Hips-1 vertoont in vergelijking tot de groep Gezonden-1 lagere BF-III skores.

(N.B. Skores op BF-III zijn altijd van een positief teken voorzien. Een relatief lage skore korrespondeert inhoudelijk met een hoge positieve waardering voor "aktiviteit en werken".)

Voorspelling 4. De groep Hips-1 vertoont in vergelijking tot de groep Astma-1 lagere skores op BF-III.

Voorspelling 5. De groep Hips-1 vertoont in vergelijking tot de groep Gezonden-1 lagere skores op $B F^{-W}$.

(N.B. Skores op BF-V zijn altijd van een negatief teken voorzien. Een relatief lage skore op $B F-V$ korrespondeert inhoudelijk met mér "gesteld zijn op omgang met mensen".)

Voorspelling 6. De groep Hips-1 vertoont in vergelijking tot de groep Astma-1 lagere BF-V skores. 
Voorspelling 7. De groep Hips-1 vertoont in vergelijking tot de groiep Gezonden-1 hogere BF-VI skores.

(N.B. Skores op BF-VI zijn altijd van een positief teken voorzlen. Wen hoge skore op BF-VI korrespondeert inhoudelijk met meer "beroepswerantwoondelijkheid" ".)

Voorspelling 8. De groep Hips-1 vertoont in vergelijking tot de groep Astma-1 hogere BF-VI skores.

9.3. Toetsingen en resultaten.

Bij de toetsingen zal gebruik gemaakt worden van de MannWhitney U-toets (Siegel, 1956). Als signifikantienivo wordt 5:, eerzijajg, genomen. Zie voor de toetsingsresultaten tabel 9.4.

Tabe1 9.4. Toetsingsresultaten van 8 voorspellingen voor de groepen Hips-1, Gezonden-1 en Astma-1.

\begin{tabular}{|c|c|c|c|c|c|c|}
\hline \multirow{2}{*}{$\begin{array}{l}\text { Voor- } \\
\text { spelling }\end{array}$} & \multirow{2}{*}{$\begin{array}{l}\text { BUL } \\
\text { Faktor }\end{array}$} & \multicolumn{2}{|l|}{ Hips-1 } & \multicolumn{2}{|c|}{ Gezonden-1 } & \multirow{2}{*}{$\mathbb{P}_{\text {eenzijdig }}$} \\
\hline & & M & $S D$ & M & SD & \\
\hline 1 & I $(\operatorname{Agr})$ & $-51,5$ & 108,4 & $-74,9$ & 105,9 & .02 \\
\hline 2 & II (Depr) & 418,6 & 86,8 & 418,7 & 103,7 & .32 \\
\hline 3 & $\operatorname{III}(\mathrm{Akt} i \mathrm{v})$ & 421,0 & 94,5 & 471,2 & 96,8 & $<.0005$ \\
\hline 5 & $v \quad($ Sociab) & $-520 \cdot 2$ & 112,0 & $-471,6$ & 98,3 & $<.0005$ \\
\hline \multirow[t]{3}{*}{7} & \multirow[t]{3}{*}{ VI (Ber.ver) } & 703.9 & 102,5 & 679,6 & 96,1 & \multirow[t]{3}{*}{.02} \\
\hline & & \multicolumn{2}{|c|}{ Hips -1 } & \multicolumn{2}{|c|}{ Astma-1 } & \\
\hline & & $M$ & $S D$ & $M$ & SD & \\
\hline 4 & $\operatorname{III}(\mathrm{Aktiv})$ & 421,0 & 94,5 & 454,7 & 94,0 & .04 \\
\hline 6 & v (Sociab) & $-520,2$ & 112,0 & $-502,1$ & 86.0 & .13 \\
\hline 8 & VI (Ber. ver) & 703,9 & 102,5 & 704,4 & 99,9 & $.54 \mathrm{~J}$ \\
\hline
\end{tabular}

1) Het verschil wijst in tegengestelde richting a an de voorspe 11 ing . 
9.4. Diskussie.

9.4.1. Gesteunde hypothesen.

De statistisch signiflkante bevestiging van de voorspellingen $1,3,4,5$ en 7 verleent steun aan de hypothesen $1,3,4,5$ en 7 en daarmee ook aan de algemene hypthese, dat personen met een specifiek ziektebeeld zich op bepalde psychologische onderzoeksvariabelen onderscheiden van personen, die niet door dat specifieke ziektebeeld gekenmerkt worden. Kruisvalidatie-onderzoekingen dienen echter de in ons materiaal gesteunde hypothesen meer houdbaarheid te geven.

9.4.2. Niet gesteunde hypothesen.

Voor voorspelling 2 wordt geen statistisch signifikante steun gevonden. Gezien de in tabel 9.4. vermelde gemiddelde BF-II skores kan gekonkludeerd worden, dat belde groepen een gelijke mate van depressiviteit aangeven.

ook voor voorspelling 6 wordt geen statistisch signifikante steun gevonden. Het verschil tussen de skore-gemiddelden van de groepen Hips-1 en Astma-1 ligt echter wel in de voorspelde richting. Gezien de grootte van de eenzijalige overschrijaingskans ( $\mathrm{p}=.13)$ zal bij het in hoofdstuk 10 beschreven onderzoek deze hypothese 6 nogmaals getoetst worden. voor hypothese 8 wordt geen enkele steun gevonden. Het is opvallend, dat in dit material voor hypothesen betreffende verschillen tussen Hips en Gezonden een duidelijker steun gevonden wordt dan voor hypothesen betreffende verschilien tussen Hips en Astmatici. Hiermee is een aanwijzing gegeven dat personen met een verschillende lichamelijke aandoening in bedoelde opzichten minder van elkaar afwijken dan binnen de hypothese der Psychosomatische Specificiteit verondersteld wordt. Hierop zal in hoofdstuk 11 teruggekomen worden.

9.4.3. Kritische kanttekeningen bij de resultaten.

Bij het beoordelen van bij dit onderzoek gevonden resultaten

is om een tweetal redenen enige restriktie gewenst.

1. Er werd bij de toetsingen gebruik gemaakt van materiaal dat ook op andere wijze bij het onderzoek betrokken is geweest. De 102 BuL protokollen van de groep Gezonden-1 zijn immers afkomstig uit de Basisgroep (zie 2.2.). In welke mate dit op de resultaten van invloed is, is niet na te gaan, doch zo er een invioed is, is deze als minimaal te beschouwen, aangezien de 102 "gezonde" proefpersonen minder dan 8\% van het totale Basisgroepmateriaal uitmaken.

2. De groepen Hips-1 en Gezonden-1 verschillen in:

- het doorgemaakt hebben van een levensbedrejgende ziekte; 
- het door de ziekte gehandicapt zijn, met name in het werk;

- het gehospitaliseerd geweest zijn.

Het is mogelijk, dat deze verschillen de bevestiging van bepalade hypothesen (onwillekeurig) bevorderd of tegengewerkt heeft. 
HET EERSTE KRUISVALIDATIEONDERZOEK.

10.1. Inleiaing.

In de voorafgaande hoofastukken $3 \mathrm{t} / \mathrm{m} 7$ werden via een 1 iteratuuronderzoek psychologische kenmerken van Hips geinventariseerd. Hierop gebaseerde verwachtingen werden via toetsbare hypothesen in voorspellingen ongezet en door middel van empirisch onderzoek op hun waarde getoetst.

In dat toetsingsonderzoek (zie hoofdstuk 9) werd voor 5 van de 8 daartoe opgestelde hypothesen stat1stisch signifikant steun gevonden.

Hiernavolgend zal het kruisvaliatieonderzoek woxden beschreven, door middel waarvan de houdbaarheld van deze 5 hypothesen wordt nagegaan.

voor hypothese 6 , zoals geformuleerd in 8.2 .4 ., werd bij het toetsingsonderzoek (zie hoofdstuk 9) geen statistisch signifikante steun gevonden. Op grond van de in 9.4.2. genoemde overweging bleek hertoetsing van deze hypothese 6 overigens wel de moeite waard. Van dit hertoetsingsonderzoek zal in dit hoofdstuk verslag worden uitgebracht.

10.2. Samenstelling van de experimentele-en kontrolegroepen en herkomst van de proefpersonen.

10.2.1. De experimentele groep van hartinfarktpatiënten.

Bij dit kruisvalidatieonderzoek zal gebruik gemaakt worden van BUL protokollen, ingevuld door 98 mannelijke Hips. Deze mannen hadden 2 tot 6 weken tevoren hun hartinfarkt meegemaakt, waarvoor zij onmiddelilijk opgenomen werden. Gedurende het onderzoek verbleven zij nog steeds in een Amsterdams ziekenhuis of hartrevalidatiekliniek, maar in geen enkel geval meer op een speciale hartbewakingseenheld.

Bij de samenstelling van deze experimentele groep werd uitgegaan van de door de behandelend geneesheer gestelde diagnose hartinfarkt, aangetoond door E.C.G., enzymonderzoek en anamnese. De proefpersonen van deze groep Hips-2 vulden de BuL "op zaal" in (zie tabel 10.1 en 10.2.).

10.2.2. Kriteria voor "gezond" en de samenstelling van de kontrolegroep van gezonden.

Door de medewerking van 4 Amsterdamse Gemeentebedrijven en de NV Nederlandse Ford Automobiel Fabriek te Amsterdam kon een groep mannen verzaneld worden, die beantwoordden aan vooraf opgestelde kriteria voor "gezond". 
Tabel 10.1. Gegevens betreffende leeftijd en opleidingsnivo van mannelijke hartinfarktpatiëten (groep Hips-2), "gezonde" mannen (groep Gezonden-2) en mannelijke astmatici (groep Astma-2). Zie voor opleidingsnivo tabe1 9.2.

\begin{tabular}{|c|c|c|c|c|c|c|}
\hline \multirow[t]{2}{*}{ Groep } & \multicolumn{2}{|c|}{ Leeftijd } & \multicolumn{3}{|c|}{ Opleidingsnivo } & Totaal \\
\hline & $M$ & $\mathrm{SD}$ & I & II & III & \\
\hline Hips-2 & $52,8 \mathrm{jr}$ & $6,4 \mathrm{jr}$ & $n=80$ & $n=11$ & $n=7$ & 98 \\
\hline Gezonden-2 & $52,1 j r$ & $6,1 \mathrm{jr}$ & $n=67$ & $\mathrm{n}=22$ & $\mathrm{n}=8$ & 98 \\
\hline Astma-2 & $51,3 \mathrm{jr}$ & $9,6 \mathrm{jr}$ & $n=31$ & $n=6$ & $\mathrm{n}=3$ & 40 \\
\hline
\end{tabular}

Tabel 10.2. Herkomst van hartinfarktpatiënten (groep Hips-2), die tijdens het invullen van de BUL in verschillende instellingen opgenomen waren.

\begin{tabular}{|c|c|c|}
\hline Instelling & & $\begin{array}{l}\text { Voor de verleende medewerking } \\
\text { met dank aan: }\end{array}$ \\
\hline Wilhelmina Gasthuis & $\mathrm{n}=54$ & $\begin{array}{l}\text { Prof.dr. M. Koster } \\
\text { Prof.dr. J. Vreeken }\end{array}$ \\
\hline Binnengasthuis & $\mathrm{n}=12$ & Dr. A.J. Dunning \\
\hline $\begin{array}{l}\text { Weesperplein } \\
\text { ziekenhuis (voormalig) }\end{array}$ & $n=28$ & J.P. Damme \\
\hline $\begin{array}{l}\text { Revalidatiekliniek } \\
\text { Overtoom }\end{array}$ & $n=4$ & $\begin{array}{l}\text { Dr. A.A. Pit } \\
\text { A. Vermeulen }\end{array}$ \\
\hline Totaal & 98 & \\
\hline
\end{tabular}


Arbitrain werd als eerste kritemium voor "gezond" gesteld: a. de afgelopen 5 jaar geen ziekteverzuim van neer dan 10 dagen pex kalenderjaar.

Dit werd angevuld met de 2 bijkomende kriteria:

b. de man mocht niet lijden of ooit geleden hebben aan en interne ziekte (bv. ulcus ventriculi et duodeni, astma, colitis ulcerosa, leverziekten, nierziekten, hartinfarkt) of aan een andexe exnstige of chronische ziekte.

c. de man mocht nooit wegens psychische klachten met een psychiater of psycholoog kontakt hebben gehad.

Bij de 4 Gemeentebedrijven werden de ziekteverzuimaarten van aldaar werkzame mannen doorgenomen. Namen en adressen van mannen van 30 jaar en ouder, die gedurende de jaren 1968 t/m 1972 per jaar niet meer dan 10 werkagen wegens ziekte bleken verzuind te hebben, werden geselekteerd en doorgegeven aan de 9 respektievelijke kontroleartsen.

De hulp van deze artsen werd ingeroepen in verband met kriteria b. en c.. Deze kontroleartsen zijn in hun kaartsysteen nagegaan, of door middel van kriterium a. voorgeselekteerde mannen voldeden a an kriteria b. en c.. Indien lemand hieraan niet voldeed, werd hij van verdere deelname aan het onderzoek uitgesloten. Bij de Ford Fabriek in Amsterdam werden door de bedrijfsarts, met behulp van de medische status, mannen van 30 jaax en ouder geselekteexd volgens dezelfde kriteria a., b. en c. voor "gezond". De aldus geselekteerde mannen werd schriftelijk gevraagd, of zij aan het onderzoek wilden meewerken. Door in totaal 255 mannen werd op wrijwillige basis de But in werktija ingevuld.

Uit deze groep van 255 mannen werd voor dit kruisvalidatieonderzoek een kontrolegroep van 98 "gezonde" manmen samengesteld, aanqeduid als qroep Gezonden-2. Vervolgens werd bij elk Hip-protokol ex ën van een "gezonde" gezocht met overeenkonende leeftijd en hetzelfde opleidingsnivo. Wanneer meerdere protokollen in aammerking kwamen, werd ex aselekt én uitgekozen. Voor nadere gegevens over deze groep Gew zonden-2 zie de tabelien 10.1. en 10.3..

* Met dank aan: Mw. S.M.A.C. Welleman; Mw. M.B. van WezelEngbersen; W. van der Ban; J.G. van Beek; G.H. Dorsman; W. Ezechiels; J.J. Furstner; J.A. de Jong; H. van de Meer. 
Tabel 10.3. Werkplaatsen en aantal personeelsleden die hun medewerking aan het verzamelen van BUL-protokollen hebben verleend.

\begin{tabular}{|c|c|c|}
\hline Instelling & & $\begin{array}{l}\text { Met dank voor hun medewerking } \\
\text { aan: }\end{array}$ \\
\hline $\begin{array}{l}\text { NV Neder1. Ford } \\
\text { Automobiel Fabriek, } \\
\text { Amsterdam. }\end{array}$ & $n=85$ & H. Holboom \\
\hline Gemeente Energiebedrijf & $n=76$ & $\begin{array}{l}\text { H. Eenhoorn } \\
\text { P. Voet }\end{array}$ \\
\hline $\begin{array}{l}\text { Gemeentelijke Brand- } \\
\text { weer. }\end{array}$ & $\mathrm{n}=17$ & G. Herkemeij \\
\hline $\begin{array}{l}\text { Gemeentelijk Giro- } \\
\text { kantoor. }\end{array}$ & $n=24$ & M.L.C. Knufman \\
\hline $\begin{array}{l}\text { Gemeentelijk Haven- } \\
\text { bedrijf. }\end{array}$ & $\mathrm{n}=53$ & H. Leenaars \\
\hline Total & 255 & \\
\hline
\end{tabular}

10.2.3. De kontrolegroep van astmapatienten.

Tussen 1966 en 1972 werd door 54 mannen, die wegens astma in verschillende instellingen opgenomen waren, de BuL ingevuld. ook hier gold als kriterium de medische diagnose, zoals vastgesteld door de behandelend geneesheer. Uit deze groep van 54 werden de 40 BUL-protokollen gekozen van de mannen die kwa leeftijd en opleidingsnivo met die van de groep Hips-2 overeenkwamen.

Voor nadere gegevens betreffende deze groep Astma-2 zie tabel 10.1. en 10.4 . 
Tabe1 10.4. Herkomst van mannelijke astmatici, die tijdens het invullen van de BUL wegens hun astma in een ziekenhuis opgenomen waren.

\begin{tabular}{|c|c|c|}
\hline Instelling & & Opmerkingen:- \\
\hline Wilhelmina Gasthuis & $n=21$ & $\begin{array}{l}\text { Deze astmatici werden vanuit de } \\
\text { Paviljoens } 1 \text { en } 5 \text { voor behandeling } \\
\text { verwezen naar de psychosomatische } \\
\text { werkgroep. }\end{array}$ \\
\hline $\begin{array}{l}\text { Stichting Academisch } \\
\text { Ziekenhuis Utrecht. } \\
\text { Afd. KJiniek voor } \\
\text { Longziekten. }\end{array}$ & $n=12$ & $\begin{array}{l}\text { Met dank aan: } \\
\text { Dr. P.J. Bangna. }\end{array}$ \\
\hline $\begin{array}{l}\text { Zeehospitium } \\
\text { Katwijk. }\end{array}$ & $n=7$ & $\begin{array}{l}\text { Met dank aan: } \\
\text { Drs. H.M. van der Ploeg. }\end{array}$ \\
\hline Totaal & 40 & \\
\hline
\end{tabular}

10.3. Voorspellingen, toetsingen en resultaten.

Uit de in hoofdstuk 8 genoemde hypothesen $1,3,4,6$ en 7 zijn de voorspellingen afgeleid, zoals vermeld in tabel 10.5. Bij de toetsingen zal gebruik gemaakt worden van de MannWhitney U-toets (Siegel, 1956). Als signifikantienivo wordt 5: eenzijdig, aangehouden. zie voor toetsingsresultaten tabel 10.5 .

10.4. Diskussie.

10.4.1. Gesteunde hypothesen.

Bij dit kruisvalidatieonderzoek wordt voor de tweede mad. steun gevonden voor de in hoofdstuk 8 genoemde hypothesen 1 , 3,5 en 7 . Hiermee wordt de houdbaarheid van deze hypothesen bevestiga.

10.4.2. Niet-gesteunde hypothesen.

De onderzoeksbevindingen verlenen geen steun aan hypothesen 4 en 6 . Wat betreft hypothese 6 wijzen zij zelfs in tegengestelde richting. Ter verklaring van deze uitkomsten doen zich de volgende mogelijkheden voor:

(a) de groep Hips-2 skoort $\neq$ de groep Hips-1 op BF-IIT en 

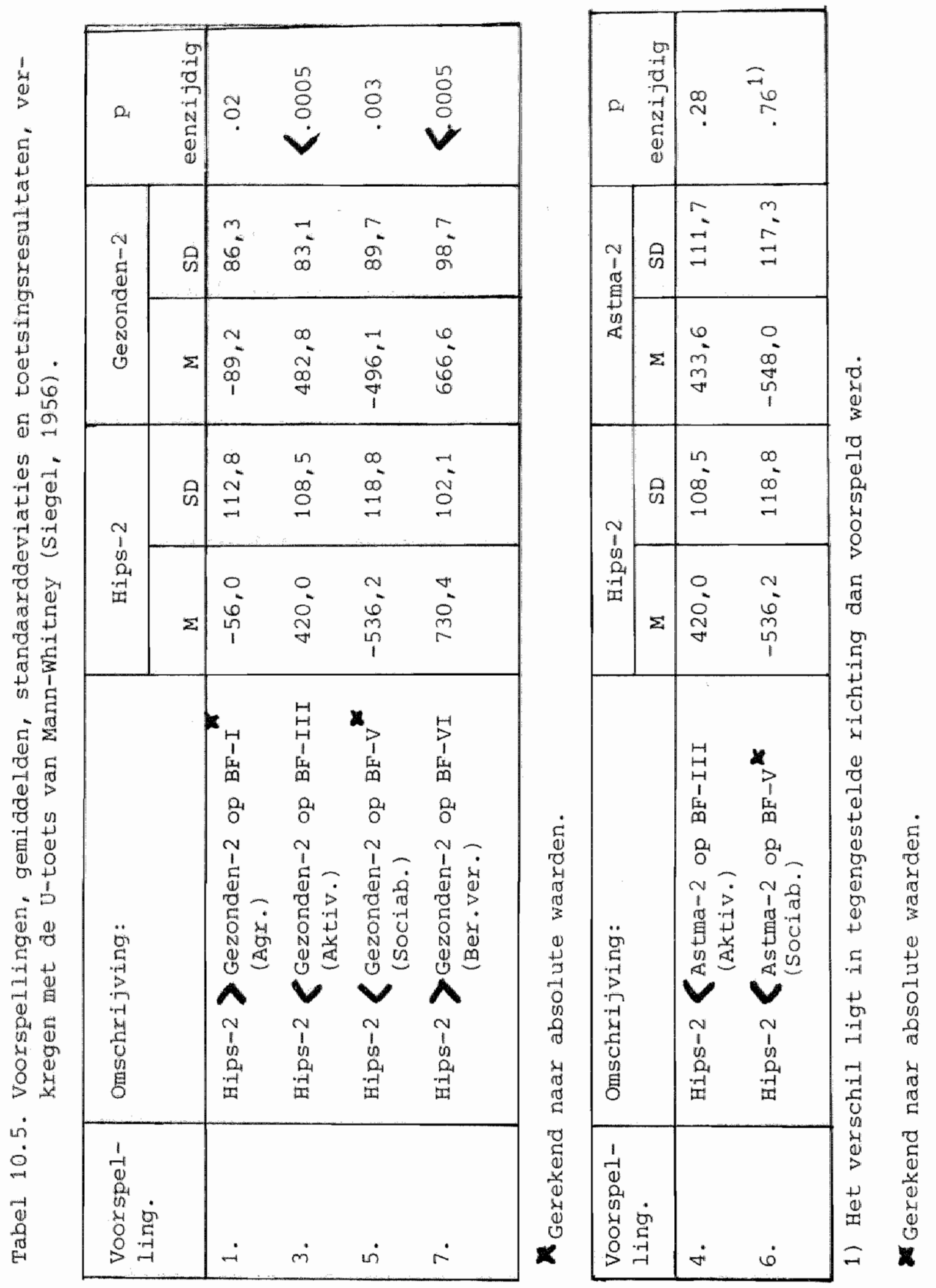
En/of:

$$
\mathrm{BE}-\mathrm{V} \text {; }
$$

(b) de groep Astma-2 skoort $\neq$ de groep Astma-1 op BF-III en $B F-V$.

De toetsingsgegevens uit tabel 10.6. Wexlenen geen duidelijke steun an de veronderstelling, dat de groep Hips-2 op BF-III afwijkend skoort van de groep Hips-1.

De toetsingsgegevens uit tabel 10.7. vexlenen geen duidelijke steun aan de veronderstelling, dat de groep Astma-2 op BF-III afwijkend skoort wan de groep Astma-1, mar de hoogte van het signifikantienivo $(\mathrm{p}=.11)$ pleit ook niet voor het tegendeel. De groep Astma-2, bestaande uit opgenomen mannelijke astmatici. tendeert tot lagex skoren op BF-III dan de groep Astma-1, bestaande uit niet-opgenomen astmatici. Door de groep opgenomen astmatici wordt derhalve een hogere positieve waardering voor "aktiviteit en werken" aangegeven dan door de niet-opgenonen groep.

Het niet ultkomen van voospelling 4 lijkt dan ook eerdex samen te hangen met een afwijkend skorepatroon tussen de astma-groepen dan tussen de Hips-groepen.

Bij voorspelling 6 ligt de uitkomst zelfs niet in de voorspelde richting. De toetsingsgegevens uit tabel 10.6. verlenen geen duidelijke steun an de veronderstelling, dat de groep Hips-2 op BF-V afwijkend skoort van de groep Hips-1.

Tabel 10.6. Skores op BUL-faktoren III en $V$ van de groepen Hips-1 en Hips-2. Verschillen werden onderzocht met de U-toets van Mann-Whitney (Siege1, 1956).

\begin{tabular}{|l|r|r|r|r|c|}
\hline \multirow{2}{*}{ BUL-Faktor } & \multicolumn{2}{|c|}{ Hips-1 } & \multicolumn{2}{c|}{ Hips-2 } & \multirow{2}{*}{ p } \\
\cline { 2 - 6 } & M & SD & M & SD & enzijdig \\
\hline III Aktiviteit & 421,0 & 94,5 & 420,0 & 108,5 & .30 \\
V Sociabiliteit & $-520,2$ & 112,0 & $-536,2$ & 110,8 & .19 \\
\hline
\end{tabular}

De toetsingsgegevens uit tabel 10.7. verlenen duidelijke steun aan de veronderstelling, dat de groep Astma-2 op BF-V lager skoort dan de groep Astma-1. De groep opgenomen astmatici blijkt dus een hogere mate van"gesteld-zijn op ongang met mensen" aan te geven dan de groep niet-opgenomen astmatici. Het tegen de voorspelling in gerichte toetsingsresultat van voorspelling 6 is hiermee op zich verklaarbaar.

Uit publikaties betreffende de psychologie van de ziekenhulspatiënt is bekend hoezeer de ziekenhuissituatie het gedrag 
en de beleving van aldaar opgenomen mensen beinvioed (zie o.a. Bremex, 1971, 1972).

Wat dat betreft is het niet verwonderljik dat astmatici. die In en ziekenhuis zijn opgenomen anders reageren, in cust op faktoken als aktiviteit en werken en sociabiliteit, resp. BF-III en V, dan astmatici welke niet in een ziekenhuis of kliniek verblijven. De onderhavige anderzoeksgegevens betreffende de Hips duiden er overigens op, dat deze ziekenhuispsychologische invioed in deze voor hartinfarktpatienten niet lijkt te gelden.

Het is opvallend, dat bij dit eerste kruisvalidatieonderzoek geen enkel statistisch signifikant verschil gevonden wordt tussen hartinfarktpatienten en astmatici. Dit vormt opnieuw een aanwijzing voor de verondersteling, dat verschillen tussen groepen personen met verschillende ziekten niet zo naar voren komen als men volgens de algemene hypothese der Psychosomatische specificiteit zou verwachten.

Tabel 10.7. Skores op BUL-Faktoren III en V van de groepen Astma-1 en Astma-2. Verschilien werden onderzocht met de U-toets van Mann-Whitney (Siegel, 1956).

\begin{tabular}{|c|c|c|c|c|c|}
\hline \multirow{2}{*}{ BUL-Faktor } & \multicolumn{2}{|c|}{ Astma-1 } & \multicolumn{2}{|c|}{ Astma-2 } & \multirow{2}{*}{ P } \\
\cline { 2 - 5 } & $M$ & SD & $M$ & SD & eenzijalg \\
\hline III Aktiviteit & 454,7 & 94,0 & 433,6 & 111,7 & .11 \\
V Sociabiliteit & $-502,1$ & 86,0 & $-548,0$ & 117,3 & .01 \\
\hline
\end{tabular}

10.4.3. Bevindingen bij een hertoetsingsonderzoek vam hypothesen 2 en 8 .

Gezien de resultaten van het toetsingsonderzoek betreffende hypothesen 2 en 8 (zie 9.4.2.), konden deze bejde hypothesen bij deze kruisvalidatie niet onderzocht worden op hun houdbaraheid.

Ult een exploratief oogpunt echter wordt het toch de moite ward geacht deze hypothesen aan ait kruisvalidatiemateriaal te onderzoeken.

De gegevens betreffende hypothese 2 ("depressiviteit" bij de groepen Hips-2 en Gezonden-2) staan in tabel 10.8. vermeld. Fypothese 2 blijkt niet statistisch signifikant (ex 5\%) gesteund. Wederom wordt dus geen steun gevonden voor de hypothese dat Hips, in vergelijking tot "gezonde" mannen, een hogere mate van "depressiviteit" aangeven. 
Tabel 10.8. Skores op BUL-Faktoren II en VI van de groepen Hips-2, Gezonden-2 en Astma-2. Verschilien wexden onderzocht met de U-toets van Mann-Whitney (Siegel, 1956).

\begin{tabular}{|c|c|c|c|c|c|c|c|}
\hline \multirow[t]{2}{*}{ BUL-Faktor } & \multicolumn{2}{|c|}{ Hips -2} & \multicolumn{2}{|c|}{ Gezonden-2 } & \multicolumn{2}{|c|}{ Astma-2 } & \multirow{2}{*}{$\frac{\mathrm{p}}{\text { eenzijaig }}$} \\
\hline & M & $\mathrm{SD}$ & M & $\mathrm{SD}$ & $\mathbb{M}$ & SD & \\
\hline II & & & & & & & \\
\hline $\begin{array}{l}\text { Depressiviteit } \\
\text { VI }\end{array}$ & 416.0 & 111.9 & 432,1 & 97.7 & ----- & $---\cdots$ & .21 \\
\hline $\begin{array}{l}\text { Beroepsverant- } \\
\text { woordelijkheid }\end{array}$ & 730,4 & 102,1 & $--\infty-$ & $-\infty-\infty$ & 706,3 & 102,2 & .10 \\
\hline
\end{tabular}

Het recent doorgemaakt hebben van het infarkt en de opnanesituatie bij de mannen uit de groep Hips-2 biijken - gezien deze resultaten - geen verhoging van "depressiviteit" met zich meegebracht te hebben.

Dit is in tegenspraak met wat andere onderzoekers met Depressiviteitsschalen bij (gehospitaliseerde) Hips gevonden hebben (Mordkoff en Rand (1968); Klein en Parsons (1968); Thiel e.a. (1973); Gentry e.a. (1972), (zie 4.1.5.). Di.t roept de vraag OP of BF-II wel Depressiviteit meet.

Hypothese $B$ heeft betrekking op verhoogde beroepsverantwoordelijkheid bij Hips in vergelijking tot astmatici. In tabe1 10.8. komt naar voren, dat de groep Hips-2 hoger op BF VI skoort dan de groep Astma-2 (p=.10). Hoewel voor de desbetreffende hypothese 8 geen statistisch signifikante steun gevonden wordt, bijikt er, gegeven de p-wadrde (p=.10) "ook geen aanwijzing woor het tegendeel. Nader onderzoek in deze richting lijkt dan ook zinvol, maar zal in dit proefscheift niet beschreven worden.

10.4.4. Kritusche kantekeningen bij de resultaten van de kruisvalidatie.

Bij het beoordelen var de toetsingsresultaten is enige voorzichtigheid weer gewenst. Het in 9.4.3. genoemde punt 2 is ook nu weer van toepassing.

Bij een vergelijking van het toetsingsonderzoek beschreven ir hoofdstuk 9, met dit kruisvalidatieonderzoek dient in aramerking te worden genomen dat de groep Gezonden-2 een "fresh sample" is. De skores yan deze groep zijn dus geheel onathankelijk van het materiaal dat voor de konstruktie van de BuL-faktoren gebruikt werd. 
Dit maakt de toetsingsuitslagen van de hypothesen, waarbij de groep Gezonden-2 als kontrolegroep gefungeerd heeft, des in "harder". 
HET TWEEDE KRUISVALIDATIEONDERZOEK EN EEN UITBREIDING VAN HET ONDERZOEKSTERREIN.

11.1. Inleiding.

In hoofdstuk 10 werd verslag uitgebracht van een kruisvalidatieonderzoek, warbij $0 . a$. de houdbaarheid van 5 eerder getoetste hypothesen werd nagegaan. Het 4-tal hypothesen, dat bij voorafgaand onderzoek houdbaar bleek, werd onderworpen aan een tweede kruisvalidatieonderzoek, dat hiernavolgend zal. worden beschreven.

11.2. Samenstelling van de experimentele- en kontrolegroepen en herkomst van de proefpersonen.

11.2.1. De experimentele groep van hartinfarktpatienten.

Voor dit tweede kruisvalidatieonderzoek werd gebruik genaakt van BUI protokollen, ingevuld door 63 mannen, die 2 tot 6 weken tevoren hun hartinfarkt hadden meegemaakt, waarop onmiddellijk ziekenhuisopname volgde. Tijdens het invullen vam de BUL verbleven $z i j$ in een (i.o. Ansterdams) ziekenhuis of hartrevalidatiekliniek, $z i j$ het in geen enkel geval meer op een speciale afdeling hartbewaking.

Als kriterium voor de diagnose: hartinfarkt, gold het oordeel van de behandelend geneesheex, hetgeen gebaseerd was op ECG gegevens en enzymonderzoek. Deze 63 Hips zijn andere personen dan die uit de groep Hips-2. zie voor nadere gegevens van deze groep Hips-3 de tabelien 11.1. en 11.2.

Tabel 11.1. Gemiddelde leeftijden, standaarddeviaties en oplejangsnivo"s van de groepen: hartinfarktpatienten (Hips-3, n=63), patiënten met medische diagnosen anders dan hartinfarkt (Internen, $n=63$ ) en "gezonde" mannen (Gezonden-3 n=63). zie voor opleidingsnivo tabel 9.2 .

\begin{tabular}{|l|cc|c|c|c|}
\hline \multirow{2}{*}{ Groep } & \multicolumn{2}{|c|}{ Leeftijd } & \multicolumn{2}{c|}{ Opleidingsnivo } \\
\cline { 2 - 6 } & $M$ & SD & $I$ & IT & III \\
\hline Hips-3 & $53,7 j r$ & $7,6 j r$ & $n=43$ & $n=13$ & $n=7$ \\
Gezonden-3 & $52,0 j x$ & $7,1 j r$ & $n=41$ & $n=15$ & $n=7$ \\
Internen & $53,6 j x$ & $7,7 j x$ & $n=43$ & $n=13$ & $n=7$ \\
\hline
\end{tabular}


Tabe1 11.2. Herkomst yan 63 hartinfarktpatienten (Hips-3) en 63 "interne" patienten (Internen), tijdens het invulien van de BUL opgenomen in verschillende instelingen.

\begin{tabular}{|c|c|c|c|}
\hline Instelling & $\begin{array}{l}\text { Hips-3 } \\
\text { groep }\end{array}$ & $\begin{array}{l}\text { Internen } \\
\text { groep }\end{array}$ & $\begin{array}{l}\text { Wederom dank voor hur } \\
\text { medewerking: }\end{array}$ \\
\hline $\begin{array}{l}\text { Wilhelmina } \\
\text { Gasthuis }\end{array}$ & $n=30$ & $\mathrm{n}=50$ & $\begin{array}{l}\text { Prof.dr. M. Koster } \\
\text { Prof.dx. J. Vreeken }\end{array}$ \\
\hline Binnen Gasthuis & $n=8$ & $n=7$ & Dr. A.J. Dunning \\
\hline $\begin{array}{l}\text { Weesperplein } \\
\text { ziekenhuis } \\
\text { (voormalig) }\end{array}$ & $\mathrm{n}=14$ & $n=6$ & J.P. Damme \\
\hline $\begin{array}{l}\text { Revalidatie } \\
\text { kliniek overtoom }\end{array}$ & $\mathrm{n}=11$ & $n=0$ & $\begin{array}{l}\text { Dr. A.A. Pit } \\
\text { A. Vermeulen }\end{array}$ \\
\hline
\end{tabular}

1:.2.2. De kontrolegroep van "gezonde" mannen.

Deze "gezonde" kontrolegroep bestal uit 63 mannen uit de groep van 255 "gezonde" mannen, die in hoofdstuk 10 beschreven wexd. Geen van deze 63 mannen makt deel uit van de groep Gezonden-2, wel werden zij volgens dezelfde procedure geselekteerd (zie 10.2.2.).

zie voor meer gegevens van de groep Gezonden-3 tabel $11.1 \ldots$

11.2.3. De kontrolegroep van mannen met medische diagnoses anders dan hartinfarkt en astma.

Deze groep bestat uit 63 mannen, die tijaens het invullen van de But tussen de 2 en 4 weken in een eveneens Amsterdams zlekenhuis op een afdeling voor inwendige ziekten opgenomen waren. In alle gevallen was de medische diagnose anders dan hartinfarkt en astma. Deze 63 mannen werden geselekteerd uit een groep van 91 "interne" patienten, door de variabelen leeftija en opleiding zo gelijk mogelijk te maken aan die van de Hips-3 groep.

zie voor meer gegevens van deze groep, "Internen" genoemd, de tabellen $11.1 ., 11.2$. en 11.3.

11. 3. Hypotheser.

11.3.1. Hertoetsing van 4 reeds gesteunde hypothesen.

De 4 bij voorafgaand onderzoek gesteunde hypothesen $1,3,5$ 
Tabel 11.3. Lijst betreffende diagnoses van de groep Internen, bestaande uit mannelijke patienten, opgenomen op een afdeling voor inwendige ziekten van een Amsterdams ziekenhuis.

\section{Diagnoses}

1. chronische rheumatische arthritis

2. diabetes mellitus

3. rraag/darm-aandoeningen

4. ijzergebreks-anemie

5. hypercholesterolemie

6. nieraandoeningen

7. hypertensie

8. $\mathrm{TBC}$

9. dekompensatio cordis

10. status na pheochromocytoom operatie

11. levercirrhose

12. hyperthyreoìdie

13. systeemziekte

14. recidiverende cholestase

15. kanker

16. aandoeningen van de botten

17. observatie dreigend hartinfarkt/angina pectoris

18. boezemfibrilleren

19. diabetes insipidus

20. Iongaandoeningen

21. oesophagus stricturen

22. icterus

23. lymphoreticulose

24. bloedziekte
Aantal 
en 7, zoals die in hoofdstuk 8 vermeld staan, zullen hieronder ten dexde male getoetst worden. Bij dit heronderzoek win tevens een aantal additioncle hypothesen ter ecrste toetsing betrokken. Deze toegevoegde hypothesen vormen verdere verbijzonderingen van de algemene hypothese dor psychosomatische specificiteit.

11.3.2. Vier additionele hypothesen.

Het onderzoeksprogramm van de hypothese der Psychosomatische Speciflciteit (Groen e.a. 1965) kon via een 4 tal additionele verbijzonderingen worden uitgebreid met behulp van het BUL material van de groep "Internen". Bij deze vier additionele hypothesen werd ervan uitgegaan dat er geen redenen zijn te veronderstellen, dat deze zogenaamde Internen gekenmerkt zouden worden door een van het "normale" afwijkende beoordeling van uitspraken betreffende:

(1) Agressiviteit;

(2) Aktiviteit en werken;

(3) Gesteld zijn op omgang met mensen;

(4) Beroepsverantwoordelijkheid.

op grond van dit uitgangspunt werden als verbijzonderingen de volgende hypothesen geformuleerd:

Eypothese 9. Mannelijke hartinfarktpatienten vertonen meer "agressiviteit" bij het beoordelen van uitspraken die daar betrekking op hebben, dan mannen met medische diagnoses anders dan hartinfarkt en astma.

Hypothese 10. Mannelijke haxtinfarktutienten vertonen meex positieve wardering bij het beoordelen van uitspraken die op "aktiviteit en werken" betrekking hebben, dan mannen met medische diagnoses anders dan hartinfarkt en astma.

Hypothese 11. Mannelijke hartinfarktpatiënten warderen uitspraken die op "gesteld zijn op ongang met mensen" betrekking hebben, hoger dan mannen met medische diagnoses anders dan hartinfarkt en astma.

Hypothese 12. Mannelijke hartinfarktpatiënten waarderen uitspraken die op "beroepsverantwoordelijkheid" betrekking hebben positiever dan mannen met medische diagnoses anders dan hartinfarkt en astma.

11.4. Voorspellingen, toetsingen en resultater.

Uit de in hoofdstuk 8 genoemde hypothesen $1,3,5$ en 7 en uit de in 11.3 .2 . toegevoegde hypothesen $9,10,11$ en 12 zijn de voorspellingen afgeleid zoals weergegeven in tabel 11.4 . 

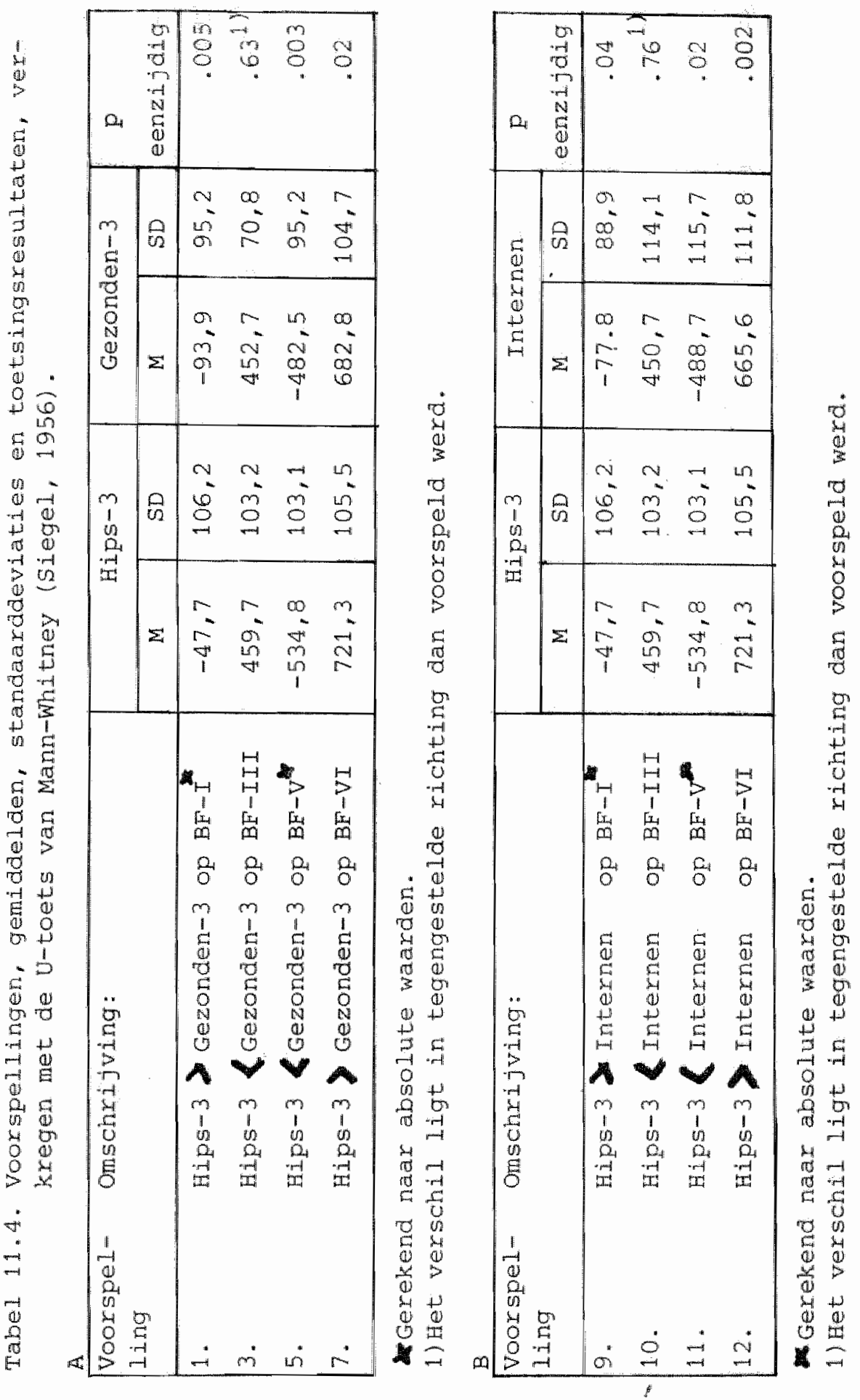


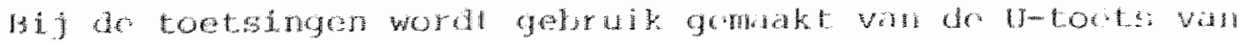
Mann-Whitney (Siegel, 1956). Als signifikantionivo worlt 5 " eerizijaig, genomen.

zie voor toetsingsresultaten tabel 11.4..

\subsection{Onderzoeksbevindingen en diskussie.}

11.5.1. Bevindingen bij BuL-Faktor I: Agressiviteit.

Voox de hypothese, dat mannelijke Hips, in vergelijking tot

"gezonde"mannen, in het beoordelen van desbetreffende uitspraken, meex agressiviteit weergeven wordt voor de derde mad steun gevonden. Aangezien deze hypothese een verbijzondering vormt wan de hypothese der Psychosomatische speciEiciteit werd deze latst genoemde opnieuw, zij het indirekt en partieel, mede gesteund. Gezien de uitslag van voorspelling 9 geldt deze verbijzondering ook, wanneer Hips vergeleken worden met mannen met medische diagnoses anders dan hartinfarkt en astma. Via kruisvalidatieonderzoek echter zal de houdbaarheid van deze laatste uitspraak nader onderzocht moeten worden.

11.5.2. Bevindingen bij BUL-Faktor III: Aktiviteit en werken.

In twee voorafgaande onderzoekingen werd steun gevonden voor de hypothese, dat mannelijke Hips, in vergelijking tot "gezonde" mannen, een hogere positieve waardering vertonen bij het beoordelen van uitspraken betreffende "aktiviteit en werken" "

Bij dit tweede kruisvalidatieonderzoek vindt deze hypothese niet opnieuw steun (zie tabel 11.4.).

In een poging hiervoor een verklaring te vinden, werden de gemiddelde BF-III skores van zowel de Hips als de Gezonden groepen nader bezien. Deze kunnen voor de Hips-groepen in tabe1 11.5. gevonden worden.

U1t deze tabel 11.5. blijkt, dat de groep Hips-3 de hoogste gemiddelde BF-III skore vertoont, dat wil zeggen de minst positieve watrdering voor "aktiviteit en werken" voorts blijkt, at de groep Hips-3 statistisch signifikant ( 65 ) hoger skoort dan de groepen Hips-1 en Hips-2. De veronderstelling dat het al of niet opgenomen zijn een rol speelt gaat in deze niet zonder meer op, aangezien de groep Hips-2 ook opgenomen patiënten betreft en op BF-III niet afwijkt van de groep Hips-1 (=niet opgenomen).

De verklaring voor deze gekonstateerde verschillen in BF-III skoregemiddelden blijft onduidelijk. De afwijking van de groep Hips-3 op BF-III ligt overigens wel in de ongunstige richting voor wat betreft de te toetsen hypothese 3. 


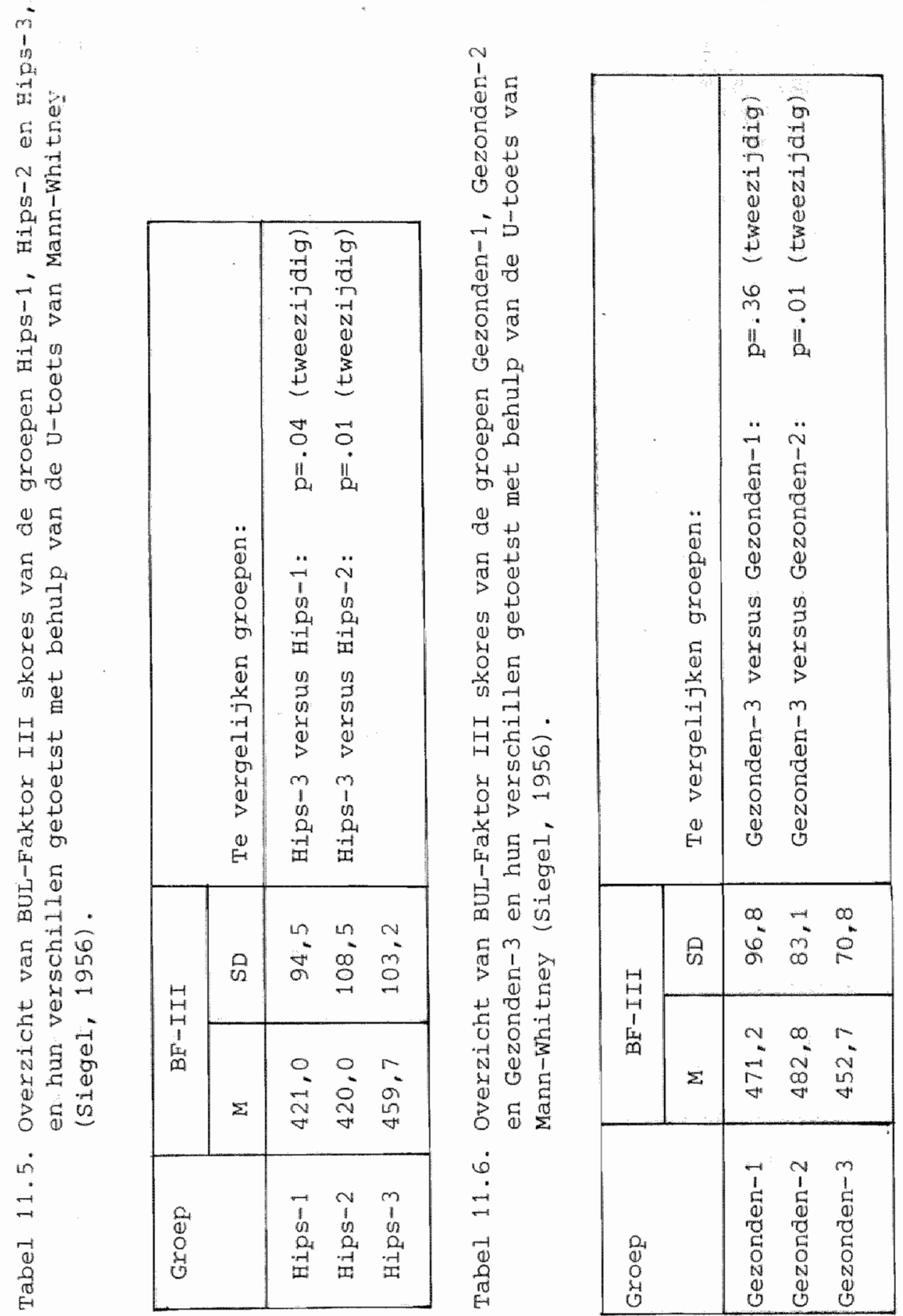


De gemiddelde BF-III skores van de drie Gezonden groepen stan in tabe1 11.6. vermeld.

U1t deze tabel 11.6. komt naar voren, dat de groep Gezonden3 de laagste gemiddelde BF-III skore vertoont. In vergelijking tot de twee overige groepen vertoont deze groep dus de hoogste positieve wardering voor "aktiviteit en werken". Het statistisch signifikante verschil ( $\times 5$ g) in gemiadelde BF-III skores tussen de groepen Gezonden-2 en Gezonden -3 is opmerkelijk, aangezien de groepen Gezonden-2 en -3 steekproeven uit dezelfde groep van 255 "gezonde" mannen ziji.j.

De richting van het verschil in skore-gemiddelden ligt echter wel in het nadeel van de te toetsen hypothese 3 .

zowel bij de groepen Hips-3 als Gezonden-3 worden dus skoreafwijkingen op BE-III gevonden in een richting, die als nadelig beschouwd kan worden voor de te toetsen hypothese 3 . Het gegeven, dat in twee van de drie gevallen deze hypothese empirisch gesteund werd, rechtvaardigt een nadere toetsing om zodoende tot een definitief standpunt te komen inzake de houdbaarheid ervan. Deze zal echter in dit proefschrift niet beschreven worden.

ook voor hypothese 10 werd in dit material geen steun gevonden. Gegeven het feit, dat vergelijking van de groep Internen met de groep Hips-2 wel steun verleent aan hypothese 10 ( $\mathrm{p}$ (.01, eenzijaig), rechtvaardigt op zijn minst een tweede toetsing alvorens haar definitief te laten vallen. Deze zal echter niet in dit proefschrift worden opgenomen.

11.5.3. Bevindingen bij BuL-Faktor $\mathrm{V}$ : Sociabiliteit.

ook voor hypothese 5, inhoudende dat mannelijke Hips, in vergelijking tot "gezonde" mannen, een hogere positieve wardering vertonen bij het beoordelen van uitspraken betreffende: gesteld-zijn op ongang met mensen, wordt voor de derde mal steun gevonden.

Deze verbijzondering van de hypothese der Psychosomatische specificiteit wordt tu driemal empirisch gesteund.

De bevestiging van voorspelling 11 (zie tabel 11.4. B) wijst erop, dat mannelijke hartinfarktpatiënten bedoeld kenmerk ook in vergelijking tot mannen met medische diagnoses anders dan hartinfarkt en astma, vertonen. Via kruisvaliatie echter zal onderzocht moeten worden of hypothese 11, waar voorspelling 11 uit werd afgeleid, houdbaar blijft. Ook hierop zal in dit proefschrift niet nader worden ingegaan. 
11.5.4. Bevindingen bij BuL-Faktor VI: Beroepswerantwoordelijkkheld.

Voor hypothese 7, inhoudende dat mannelijke Hips een hogere positieve waardering vertonen bij het beoordelen van uitspraken die op "beroepsverantwoordelijkheia" betrekking hebben dan "gezonde" mannen, wordt eveneens voor de derde maal steun gevonden (zie tabel 11.4. A). Ook voor deze verbijzonierlng van de hypothese der Psychosomatische Specificiteit wordt derhalve een bevestiging gevonden.

De bevestiging van voorspelling 12 (zie tabel 11.4. B) steunt voorts hypothese 12 , inhoudende dat mannelijke Hips bedoeld kenmerk ook vertonen in vergelijking tot mannen met medische diagnoses anders dan hartinfarkt en astma. Via kruisvalidatieonderzoek zal onderzocht moeten worden, of hypothese 12 houdbaax blijft. Een dergelijk onderzoek zal in dit proefschrift niet beschreven worden.

11.5.5. Bevindingen bij BUL-Faktor II: Depressiviteit. Noch bij het toetsingsonderzoek uit hoofdstuk 9 , noch bij het eerste kruisvalidatieonderzoek werd steun gevonden voor hypothese 2, inhoudende dat mannelijke hartinfarktpatiënten, in vergelijking tot "gezonde" mannen, méer "depressiviteit" vertonen bij het beoordelen van uitspraken die daar betrekking op hebben.

In tabel 11.7. staan skoringsgegevens samengevat voor BF-II (Depressiviteit) uit het tweede kruisvalidatieonderzoek en de twee voorafgaande onderzoekingen.

Tabel 11.7. Gemiddelde BUL-Faktor II (Depressiviteit) skores en standaarddeviaties, behald door drie groepen hartinfarktpatiënten (Hips) en drie groepen Gezonden tijdens arie onderzoekingen. Verschillen werden onderzocht met behulp van de U-toets van Mann-Whitney (Slegel, 1956).

\begin{tabular}{|l|c|c|c|c|c|}
\hline \multirow{2}{*}{ Onderzoek } & \multicolumn{2}{|c|}{ Hips } & \multicolumn{2}{c|}{ Gezonden } & \multirow{2}{*}{$\mathrm{P}$} \\
\cline { 2 - 5 } & $\mathrm{M}$ & $\mathrm{SD}$ & $\mathrm{M}$ & \multicolumn{1}{c|}{$\mathrm{SD}$} & \multirow{2}{*}{ eenzijaig } \\
\hline 1. Toetsingsonderzoek & 418,6 & 86,8 & 418,7 & 103,7 & .31 \\
2. Eerste kruisvalidatie & 416,0 & 111,9 & 432,1 & 97,7 & .21 \\
3. Tweede kruisvalidatie & 405,6 & 103,6 & 426,3 & 103,2 & .21 \\
\hline
\end{tabular}


Uit deze tabel komt nar voren, dat ook bij het tweede Kruisval.idatiemateriad geen arnwjing gevonden wordt voor de juistheid van deze hypothese 2. Met BF-II is dus tot op heden geen empirische steun gevonden voor de $\mathrm{kli}-$ nische inarukken van b.v. Arlow (1945) en Dunbar (1948) (zie hoofdstuk 4), die juist bij patiënten met een coronaire hartziekte een verhoogde mate van depressiviteit aanwezig achten. De resultaten behald met BF-II ondersteunen veeleer de klinische indrukken van Groen en van der valk (1965, zle hoofdstuk 4), die constateerden: "An admission of weakness or depression in a dificult life situation is hardiy ever heard from them,.... Only after the heart attack has occured this may happen..." .

Echter ook nu komt weer de vraag op (zie 10.4.3.), wat BF-II "meet", of deze faktor Depressiviteit meet.

1.1.5.6. Diskussie met konklusies.

In de psychosomatische literatuur worden aan hartinfarktpatienten (Hips) bepalale persoonlijkheids- en gedragskenmerken toegeschreven, die door ons tot toetsbaar geachte hypothesen getransformeerd werden. Voor een auntal van deze hypothesen werd met behulp van psychologische variabelen bevestiging gevonden. In het algemeen bleken groepen mannelijke Hips, in vergelijking tot groepen "gezonde" mannen, een hogere mate van agressiviteit aan te geven, evenals van aktiviteitsgerichtheid, sociabiliteit en beroepsverantwoordelijkheid.

De uit de psychosomatische literatuur afgeleide hypothesen kunnen tevens gezien worden als evenzovele "verbijzondexingen" van de hypothese der Psychosomatische specificiteit zoals gedefinieerd door Groen e.a. (1965). De onderzoeksgegevens verlenen dus steun an de veronderstelling, dat Hips as groep gekenmerkt worden door "een bepalde persoonljjkheids truktur."

Bij een nadere witwerking met betrekking tot het 'specifieke' van een persoondijkheidsstruktuur merken Groen e.a. (1965) op: "(dat) het specifieke element veelal niet bestaat in een kwalitatieve abnormaliteit, doch in een kwantitatieve overdrijving van op zich normale facetten van de persoonlijkheidsstructuur,.........".

In het zogeheten "Groen-boek" (olthuis e.a., 1973) schetst Bastiaans deze 'overdrijving" vanuit de betekenis van het hysterie-konsept voor de psychosomatiek als volgt: "Het psychosomatische aanpassingsgedrag is in feite de tragische uiting van een intensief pogen on niet als hystericus beschouwd te worden. Stelt men, dat de hysterie de ziekte van 
de overarijuing is, dan moet ook worden vastgesteld, dat de Lsychosomatische patient in zijn verwoed pogen om nomaal te lijken nimmer geheol aan overarijving ontkont".

op grond van deze uitspraken kan men in het algeneen stellen: psychosomatische patienten en dus ook hartunfarktpatienten worden gekenmerkt door 'overarijuing'. In het licht van deze zienswijze kunnen de verhoogde skores van de Hips op bepaalde BuL-faktoren als evenzovele vormen van 'overdrijving' gezien worden, aangezien deze But-faktoren nauw verankerd zijn in door klinici beschreven 'overarijuingen' van Hips.

Een implikatie van de zienswijzen van Groen e.a. (1965) en van Bastiaans (1973) is, dat bij alle personen die aan een bepalale psychosomatische ziekte lijden, van ến of meerdere overdrijvingen sprake is.

kijkt men nar de grootte van de verschillen tussen de gemiddelden van de skores op de BUL-faktoren warop Hips zich van gezonden onderscheiden en naar de grootte van de standaarddeviaties, dan komt men tot de konklusie, dat er vele overlappende skores voorkomen. Met andere woorden: de veronderstelde 'overdrijving' op een bepaalde BUL-faktor wordt lang niet voor iedere hartinfarktpatient individueel gevolden.

Dit sluit aan bij ideeën van Rooymans (1974), wanneer deze het begrip "specificiteit", zoals omschreven door Alexander en medewerkers, kritisch bekijkt Alexander, 1952; Alexander en Szasz, 1952; Alexandex e.a., 1968). Bij Alexander ligt voor de veronderstelde relatie het aksent op: geen ziekte zonder een welomschreven intrapsychisch konfilkt. op grona van empirische gegevens uit de literatuur echter komt Rooymans (1974) voor maagzweerpatiènten tot de konklusie, dat onder velen van hen het onderstelde intrapsychische konflikt lijkt voor te komen, mat niet bijallen. op grona hiervan stelt hij, dat ex in dit geval niet van "specificiteit" gesproken kan worden, omdat dit een samen= hang van 100\% veronderstelt. Hij stelt voor om in plates daarvan van "typiciteit" te spreken. De uitslagen van het onderhavige onderzoek suggereren ook, dat met beter wan "typiciteit" dan van "specificitelt" kan spreken.

Wel kan men zich afvragen of de skoreverdelingen van de litps op de BUL-faktoren waarop zij zich van gezonden onderscheiden, in hun totaliteit in én bopaalde richting afwjiken. Mocht dit het geval zijn, dan zou men kumnen stellen dat Hips een bepaald kenmerk in een jets grotere mate vertonen dan gezonden. Dat zou dan een argument vormen om -althans bij de Hips- te spreken van "specificiteit". 
Om dit na te gaan werden de skoxes van de beschreven groepen Hips op de afzonderlijke BUL-faktoren I. III,V en VI gekombineerd, zodat voor elk van deze Bul-faktoren in totaal $263(102+98+63)$ skores beschikbaar kwamen. Dezelfae procedure werd op de skores van de beschreven kontrole-groepen "gezonden" toegepast.

De skowes op leder der 4 genoemde BUL-faktoren werdengezien de grootte van hun spreiding -in klassen ingedeeld, met een interval van 25 . Voor elke $k$ lasse werd vervolgens nagegaan hoeveel skores van de Hips en gezonden extoe behoren. Zo ontstonden de grafieken $1 \mathrm{t} / \mathrm{m} 4$.

Bij grafiek 1 blijkt niet de gehele verdeling van de Hips. in vergelijking tot die van de gezonden, naar rechts verschoven. Beide uiteinden van de verdelingen verstoren het op "specificiteit" - wh"jzende beeld dat in het middengebied gevonden wordt, warbinner ovexigens wel de skores van verxeweg de meeste proefpersonen vallen. Strikt genomen kunnen we ook op grond van deze gegevens wel van 'typiciteit' maar niet van 'speciticiteit' spreken.

De witspraken, gedaan t.a.v. de gegevens van grafiek 1 zijn ook op die van de grafieken $2 \mathrm{t} / \mathrm{m} 4$ van toepassing.

Bij Groen e.a. (1965) treft men nog een precisering van het begrip 'specificiteit' aan: "Het specifleke in het ziektebeeld wordt veroorzaakt door verschillen in kwantitatieve menging, veeleer dan door kwalitatieve abnormaliteiten van de psychogenetische componenten".

Eerder werd exop gewezen (zie hoofdstuk 1), dat het begrip persoonlijkheldsstruktur daarom zo ontoegankelijk is voor een empixisch onderzoek omdat dit begrip zo moeilijk is te operationaliseren. Om verschillen in persoonlijkheidsstruktuur toch te kunnen 'meten" werd ex vanuit gegaan, dat deze zich dan zouden manifesteren in een zich onderscheiden op bepalde psychologische onderzoeksvaxiabelen van groepen, warbij dergelijke verschillen verondersteld worden. Als de zienswijze juist is, dat het "specifieke" in het ziektebeeld veroorzaakt wordt door verschillen in kwantitatheve menging van nomale aspekten van de persoonlijkheidsstrukturu, dan zullen deze zich in de volgende drie afleiaingen manifesteren:

1. Personen met ziekte A onderscheiden zich op bepalde psychologische onderzoeksvariabelen van 'gezonde "personen.

2. Personen met ziekte $B$ onderscheiden zich op een aanta 1 van deze onderzoeksvariabelen miet van gezonden.

3. Pexsonen met ziekte $A$ ondexscheiden zich op tenminste een antal van deze onderzoeksvariabelen van personen met 


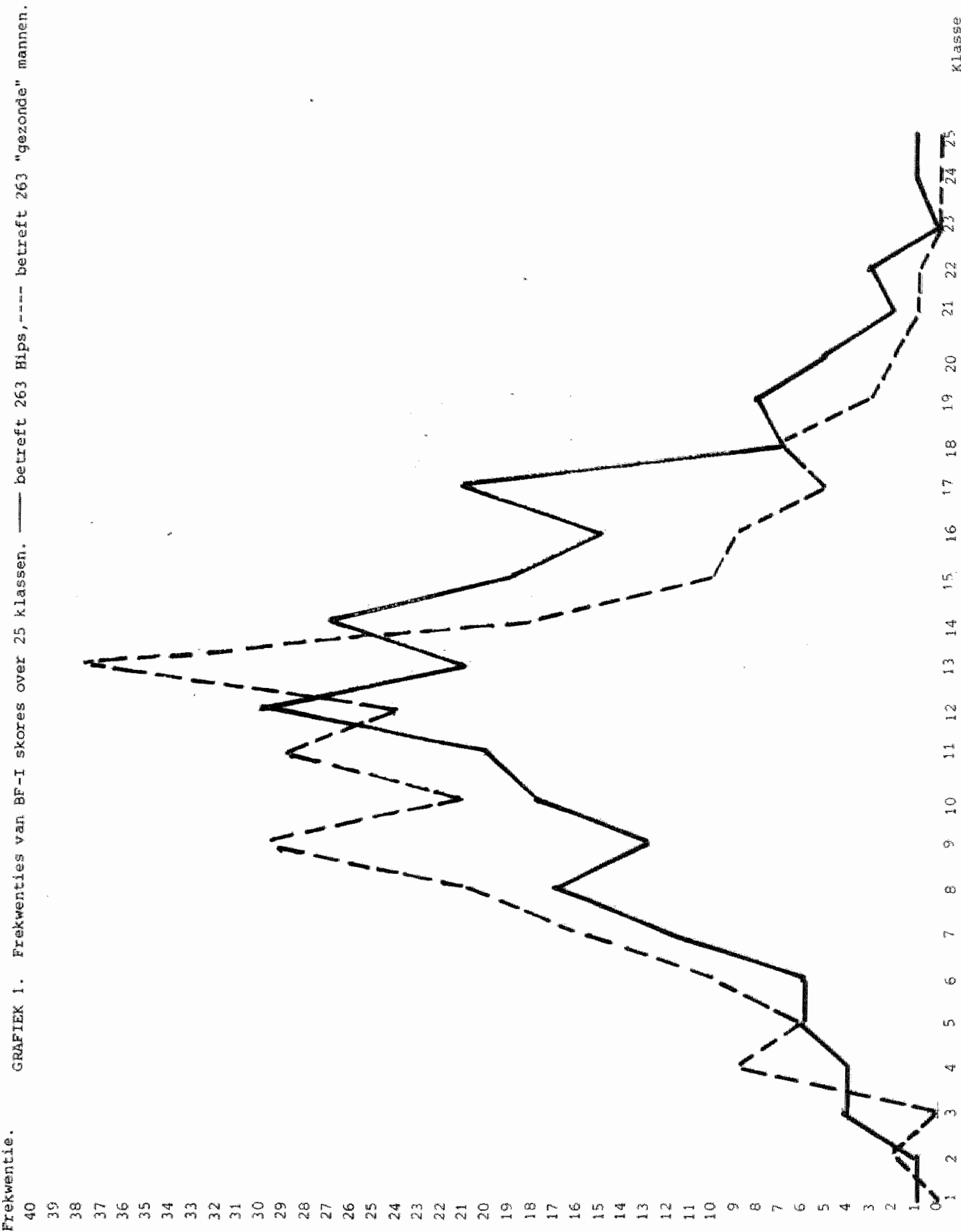




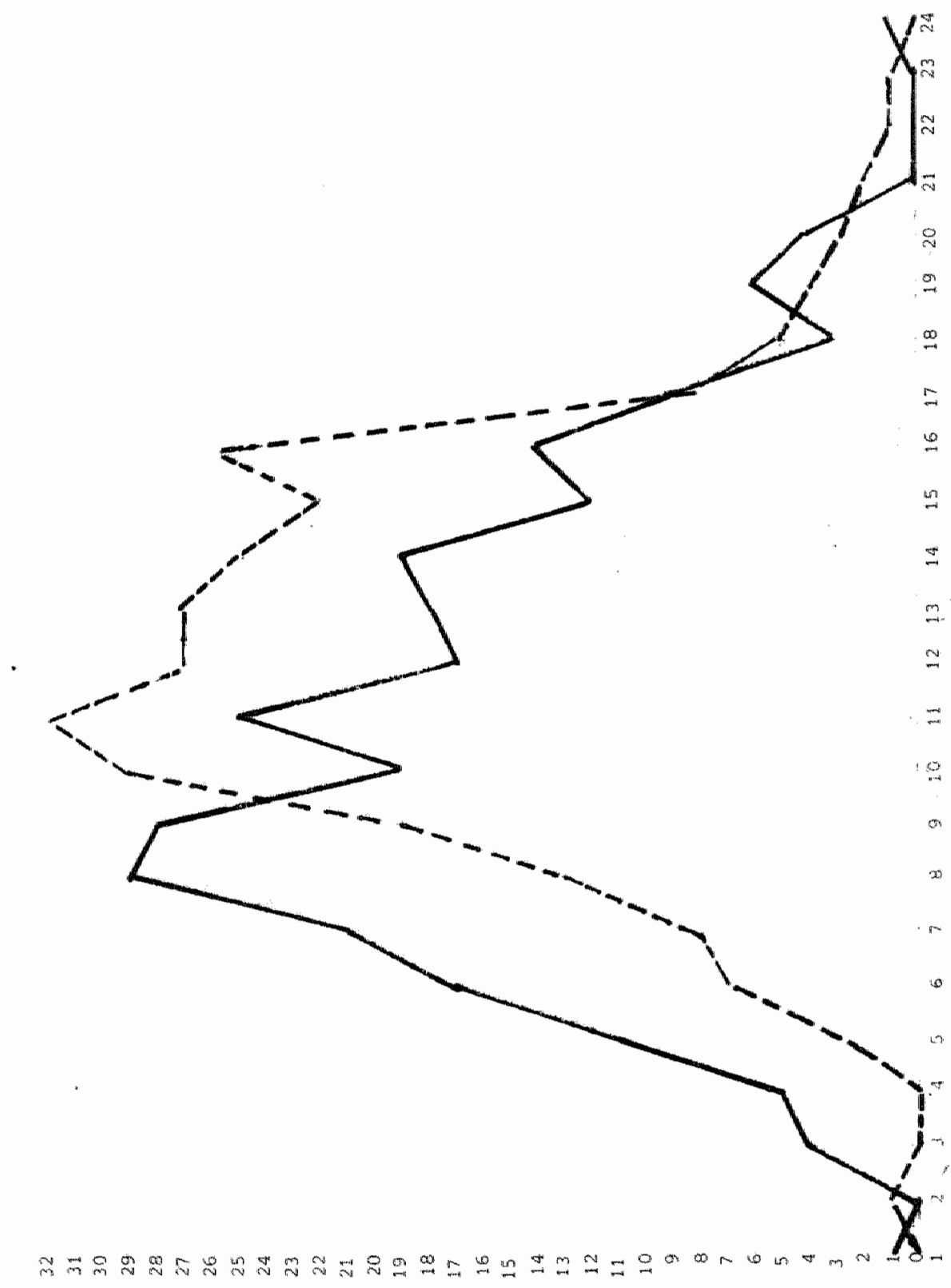




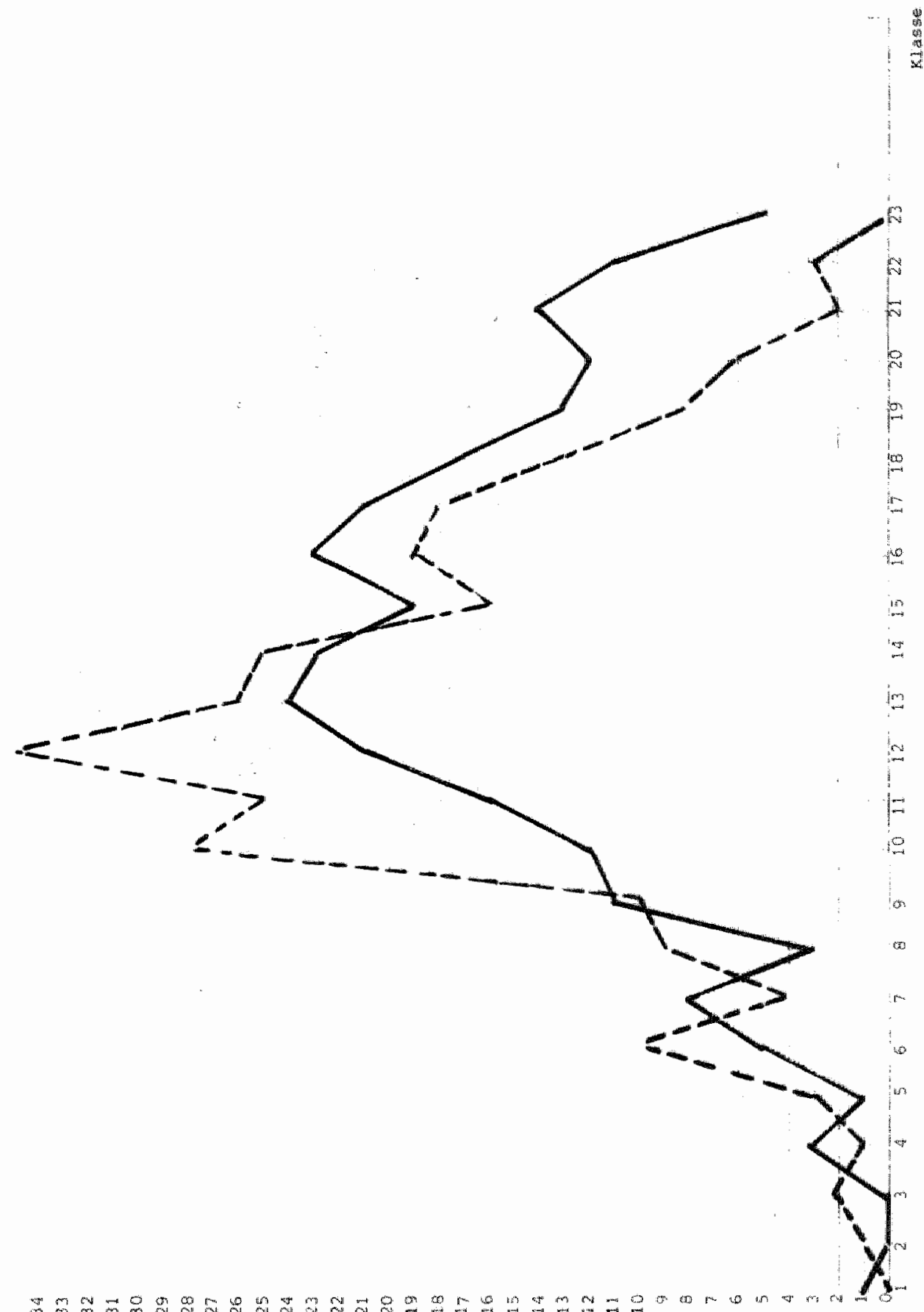




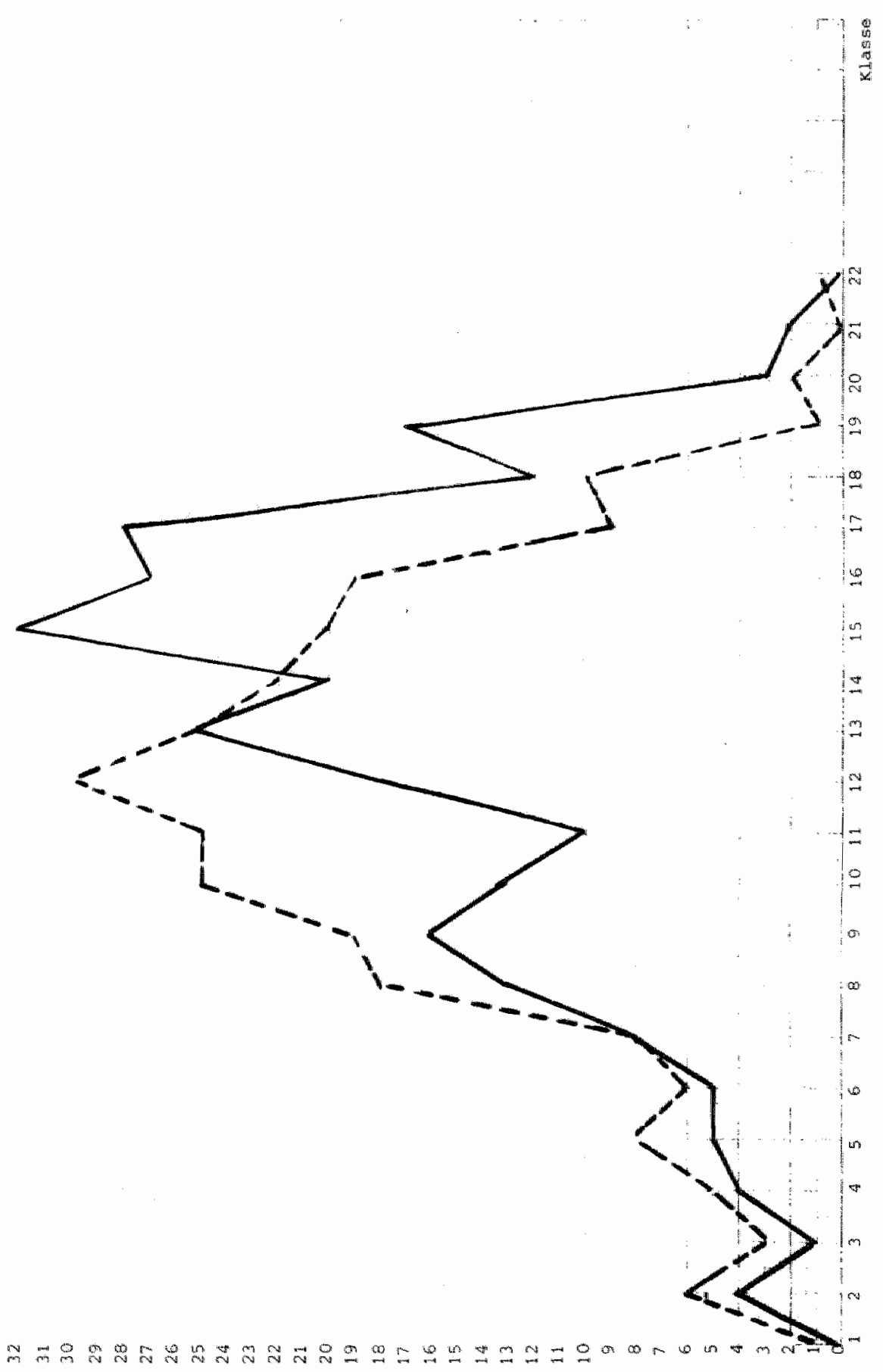


ziekte B.

Er zal nu nagegaan worden in hoeverre deze afleidngen congruent zijn met bepaalde onderzoeksbevindingen.

Ad 1. Hartinfarktpatienten (personen met ziekte A) onderscheiden zich als groep inderdad bij herhaling wan gezonden op 4 van de 5 gebruikte onderzoksvariabelen (zie 9.3.,10.3. en 11.4.). Hierboven werd echter aangetoond, dat niet iedere hartinfarktpatient een 'overarijving' op elk dezer 4 onderzoeksvariabelen (persoonlijkheidsdimensies) toont en dat er op grond daarvan, in navolging van Rooymans (1974), beter van 'typiciteit' gesproken kan worden. De onderzoeksbevindingen geven dan ook aanleiding tot de volgende uitsprak: Het is 'typisch' dat bij personen met een hartinfarkt opvallend veel personen gevonden worden die een kwantitatieve 'overarijving' vertonen van op zichaelf normale facetten van de persoonlijkheidsstruktuur.

Ad 2. In tabel 11.8. staan de resultaten van een vergelijking wan de groepen Astma-1 (personen met ziekte B) en Gezonden-1 voor dezelfde onderzoeksvariabelen, te weten $B F-I$, II, $V$ en VI.

De groep Astma-1 vertoont bij twee (Agressiviteit en Sociabiliteit) van de vier variabelen een statistisch signifikant verschil. in vergelijking tot de groep Gezonden-1. Deze verschillen liggen in dezelfde richting als die welke bij de vergelijking van de groepen Hips-1 en Gezonden-1 gevonden werd. Bij de vergelijking van de groepen Astma-2 met Gezonden-2 (zie tabel 11.9.) worden niet alleen wederom bij dezelfde variabelen signifikante verschillen gevonden, bij de twee overige onderzoeksvariabelen (Aktiviteit en Beroepsverantwoordelijkheid) wordt eveneens een verschil gevonden en in dezelfde richting als bij de vergelijking wan de groepen Hips-2 en Gezonden- 2 .

In verreweg de meeste gevallen worden bjj de astmatidi dozelfde 'overdrijvingen' gevonden als bij de luatinfarktpatienten. Deze bevinding steunt geenszins de zienswijze van Groen e.a. (1965).

Ad 3. Tabe1 11.10. toont 0.m. de p-warden voor de versehil w len tussen de groepen Hips-1 (personen met ziektebeeld $A$ ) en Astma-1 (personen met ziektebeeld B) bij 5 BUL-faktoren. Bij éen van de 5 dimensies, namelijk Aktiviteit en werken, wordt een signifikant (eenzijaig) verschil gevonden. Uit tabel 11.11. blijkt tussen de groepen Hips-2 en Astma-2 bij dezelfde 5 dimensies geen erikel signifikant verschil. ook de resultaten, weergegeven in tabej 11.11. verlenen dus geen steun aan de zienswijze van Groen e.a., betreffende verschillen in kwantitatieve menging van op zichzelf normale 


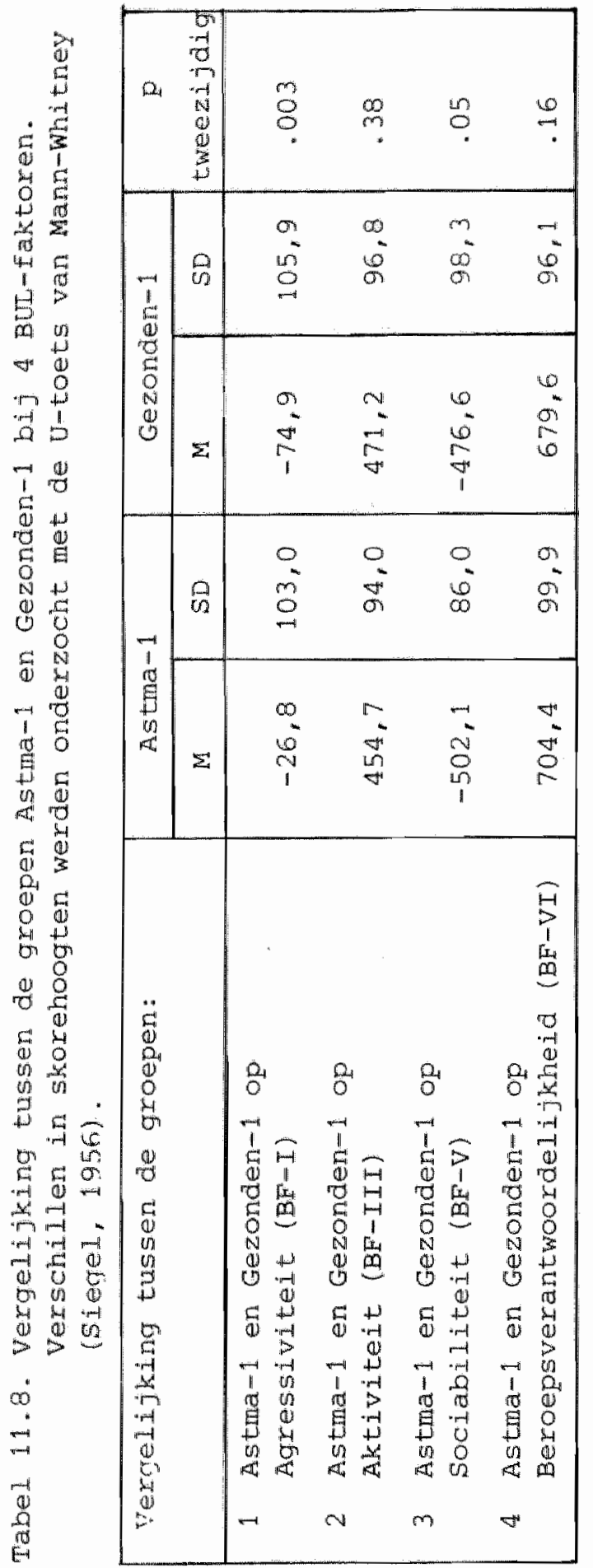

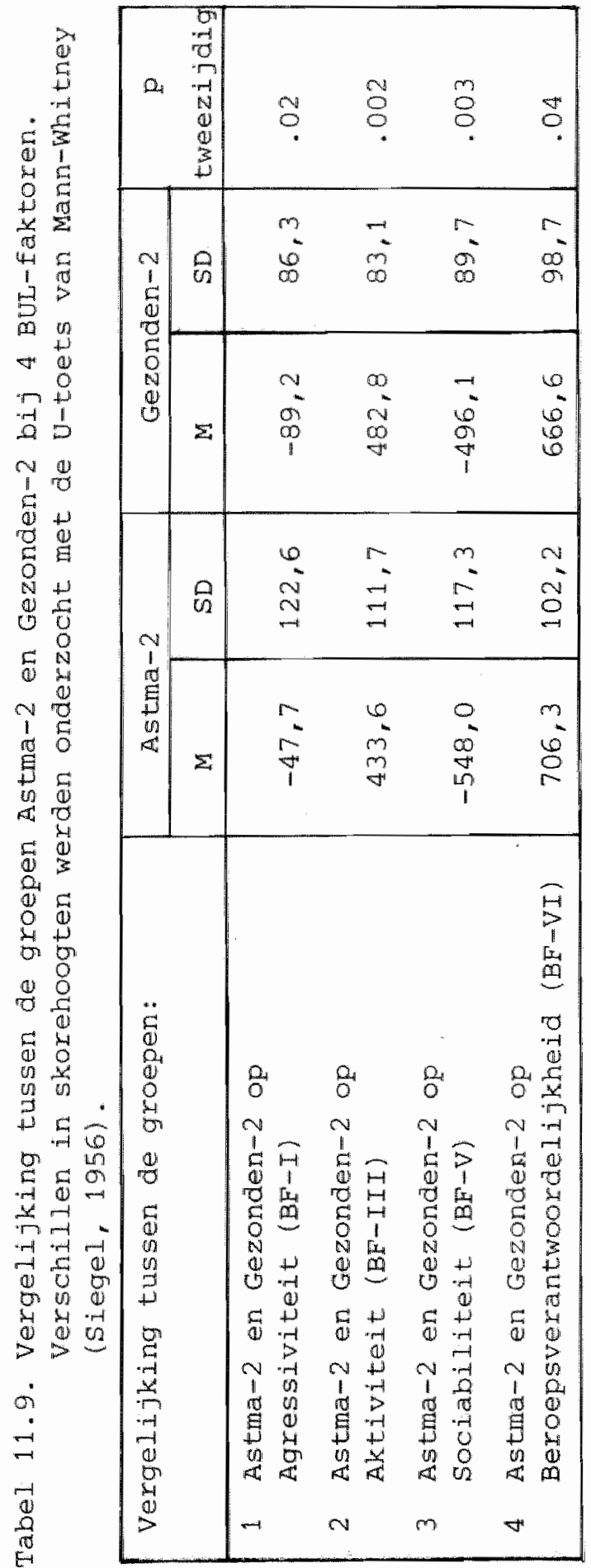




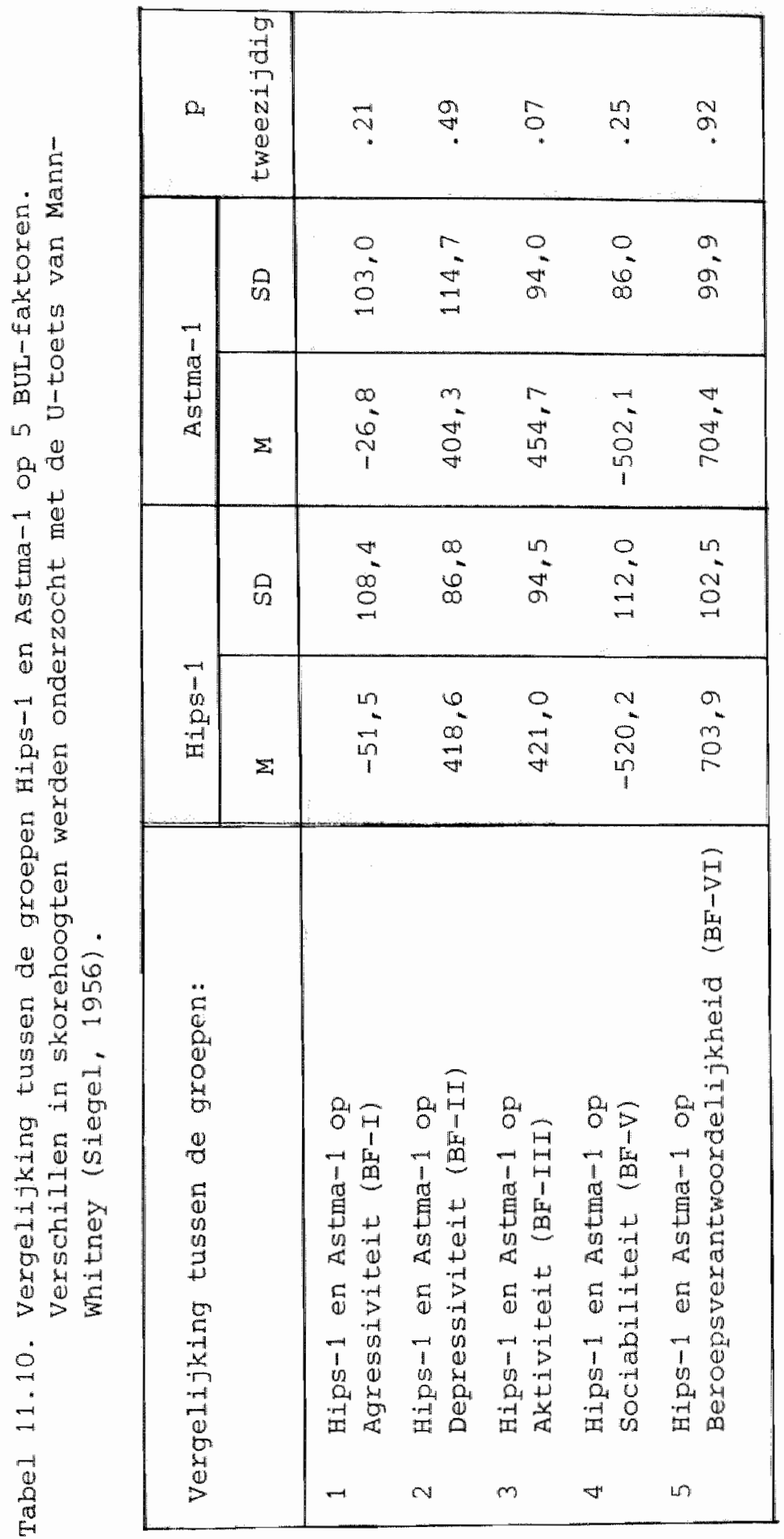




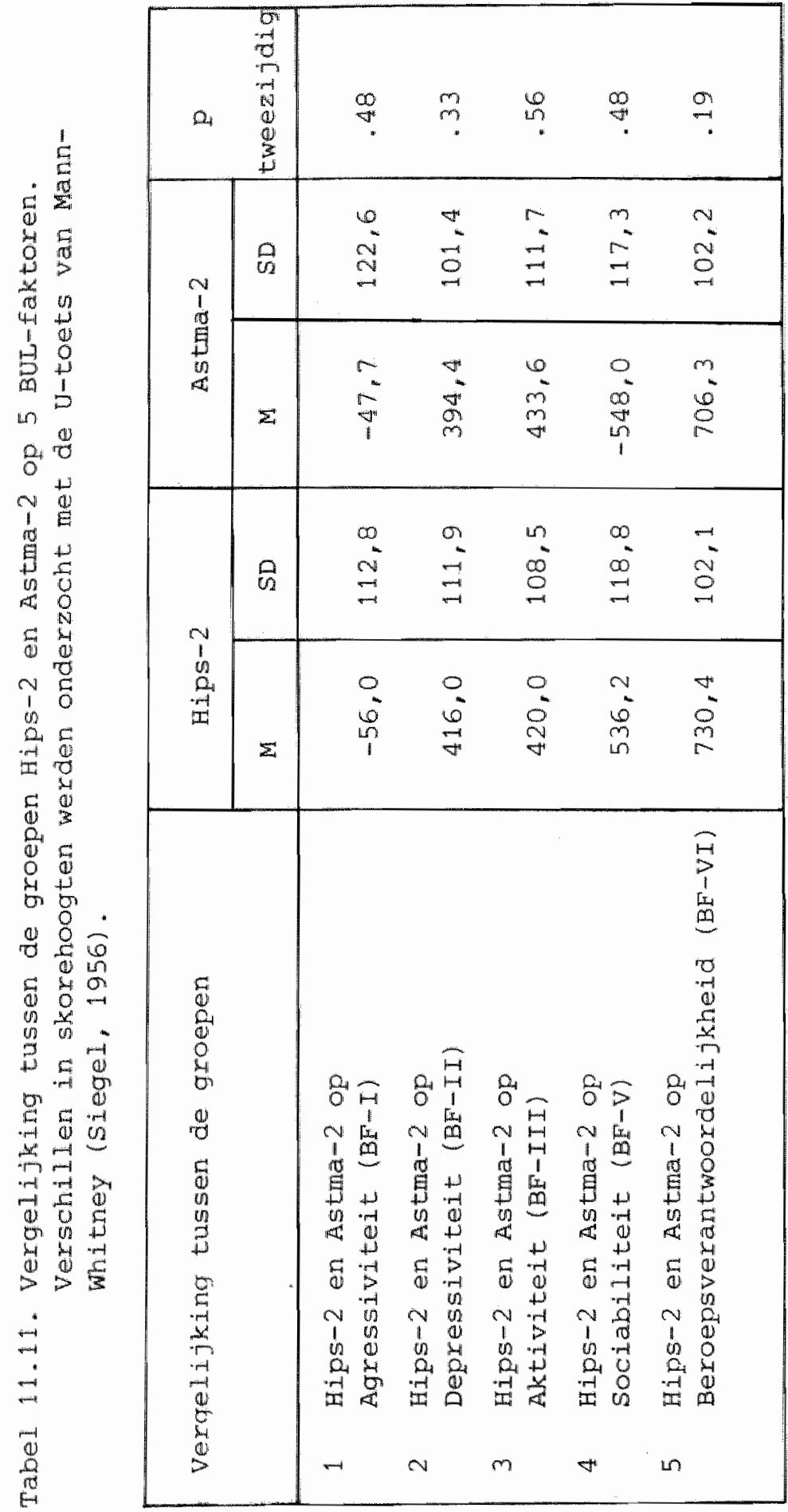


facetten van de pexsoonijkheidsstruktur bij patienten met verschillende psychosomatische ziletebelden.

Wat naar voren kont is, dat groepen personen die an de ziekte $A$ of $B$, respectievelijk hartinfarkt of astma 1 ijden, zich bij het onderhavige onderzoek in het algemeen op dezelfde onderzoeksvariabeIen onderscheiden van groepen "gezonde' personen. Anders gezegd: bepalde 'overorijuingen" zijn met verschillende somatische ziektebedden gekorreleerd. Ook dit gegeven makt, dat het begrip "specificiteit" met betrekking tot de zogeheten persooniljkheidsstruktur met de nodige reserves bezien moeten worden.

Het gegeven, dat de groep Hips-3 bij 3 van de 4 Bur-fakmor.n statistisch signifikant afwijkt van de gropp "lntmrnon" duid erop, dat deze groep in dit opzicht verschilt van de astmagroepen.

Dit geeft aanleiding tot de spekulatie dat de bij het onderhavige onderzoek gebruikte persoonlijkheidsvariabelen wèl met het ene, maar niet (of minder) met het andere specifieke ziektebeeld gekorreleerd is. Voor een nadere precisering is echter eerst een uitgebreid onderzoek vereist.

Al met al kan op grond van ons onderzoek de hypothese der psychosomatische specificiteit, zoals door Groen e.a. (1965) geformuleerd, nog niet worden verworpen. Er werd immers met slechts 5 onderzoeksvariabelen (persoonlijkheidsdimensies) gewerkt, waarmee slechts ë́n van de drie voor het ontstaan van een ziektebeeld noodzakelijk geachte kodeterminanten, onderzocht werd. Wat het onderzoek daarover geleerd heeft is, dat de relatie tussen 'bepalde ziekte' en 'bepaalde persoonlijkheidsstruktuur" of " bepalde overdrijving" minder hecht lijkt dan de specificiteitshypothese doet veronderstellen. Dat het onderkennen var een 'typisch' gedragspatroon een prognostische warde heett biy het ondexzoek nadr ontstaansvoorwarden van coronaire hartziekten, zal. in het valgende hoofdstuk beschreven worden. 


\section{A/B-TYPOLOGIE EN JENKINS ACTIVITY SURVEY (JAS).}

\subsection{Inleiding}

Bij de voorafgaande 3 eigen onderzoekingen is naar voren gekomen, dat hartinfarktpatiënten zich op bepaalde psychologische testvariabelen inderdaad onderscheiden van gezonden. Het was gedurende dit onderzoek verheugend te ontdekken hoe de Amerikaanse cardiologen Friedman en Rosenman met hun medewerkers ook bezig waren met een onderzoek, waarbij nagegaan werd of er een verband bestond tussen het hebben en het ontwikkelen van een coronaire hartziekte en bepaalde psychologische faktoren. Wanneer daarbij bepaalde overeenkomende onderzoeksbevindingen naar voren zouden komen, zouden die als steun kunnen fungeren voor de houdbaarheid van de eigen bevindingen en de eigen bevindingen zouden de resultaten uit Amerika kunnen ondersteunen. Ten tijde van de onderzoeksperiode werd het steeds duidelijker, dat er dergelijke overeenkomsten aanwezig waren en dat, terwij1 het probleemgebied door de Amerikaanse onderzoekers vanuit een geheel andere invalshoek benaderd werd. Het was voorts interessant te zien, dat deze groep van onderzoekers overging tot het konstrueren van eer psychologische test. Hierbij hadden personen zònder en personen mèt een vexonderstelde predispositie tot het ontwikkelen van een coronaire hartziekte model gestaan. Vergelijking van deze test met de BUL en de met beide onderzoeksinstrumenten behaalde onderzoeksresultaten lag toen uiteraard voor de hand. In het kader van de ontwikkeling van de $A / B$-typologie zullen hiernavolgend de bevindingen van deze vergelijking worden besproken.

\subsection{De ontwikkeling van de A/B-typologie}

12.2.1 De eerste formuleringen en onderzoekingen.

In 1955 publiceerden de twee Amerikaanse cardiologen Friedman en Rosenman, samen met hun medewerker Beyers, een overzichtsartikel over de invloed van een verstoord cholesterolmetabolisme op de ontwikkeling van de atherosclerose. De met vernauwing gepaard gaande sclerose van de bloedvaten, die in het gehele lichaam kan optreden, kan licht tot een coronaire hartziekte leiden, wanneer de vernauwing juist in de kransslagader van het hart voorkomt.

De auteurs konstateren, dat er lang niet altijd een parallellisme aantoonbaar is tussen vetten en/of cholesterol en de 
aanwezigheld van atherosclerose. Het is veeleer zo, dat een komplexiteit van faktoren hierbily een rol speelt: Naar aanleiding hiervan merken $2 i j$ op. "other factors may exhibit an even claser relationship and it is dangerous to narrow ore's study of possible causes of a disorder to only a survey of eating habits of a race or group. Indeed it seems that many American laymen, according to our personal observations, believe that the peculiar type of stress and tension to which they are exposed londerstreping van schrijver dezesy plays a more important role in their possible earliex demise than their fat or cholesterol intake (Fxiedman e.a., 1955).

om de invloed van vetten op de ontwikkeling van coronaire hartziekten (CHZ) na te gaan deden Friedman en Rosenman een onderzoek, waarbij werd uitgegaan van het gegeven, dat de Amerikaanse vrouw, die geen hypertensie en/of diabetes heeft en jonger is dan 40 jaar "...exhibits more than 20 times more resistance to symptomatic coronary disease than does her American male counterpart" (Friedman e.a., 1957). Bij een door hen onderzochte groep van vrouwen en hun echtgenoten bleek bij een vergelijking van hun vetgebruik geen belangrijk verschil aantoonbaar. Hieruit kan afgeleid worden, dat de hogere prevalentie van CFz onder mannen, in vergelijking tot vrouwen, niet zonder meer toe te schxijven is aan een verhoogde vetkonsumptie. Andere faktoren moeten medebepalend zijn voor het ontstaan van coronaire hartziekten. Een van de etiologische faktoren in deze is volgens de onderzoekers de omstandigheid, dat in Amerika de verantwoordelijkheid dragende en leidinggevende man blootstaat aan "the rapidly increasing profound emotional stresses and tensions of this society" (Friedman e.a., 1957). on meer inzicht in dit verband te verwerven ondervroegen zij, via een vragenlijst, leken en artsen over wat zij beschouwden als hoofdoorzaken voor het ontstaan van klinische CHZ.

De uitslag was verrassend. Zowel van de leken als artsen gaf ongeveer 70\% als oorzaak aan: "excessive 'drive', competition, meeting deadines, and economic frustratuons" (Firiedman e.a., 1958).

Om de relatie van deze vorm van "stresses and tensions" met CHz te onderzoeken, onderzochten zij een groep accountants. In bepaalde perioden van het jaar namelijk moeten accountants in Amerika, in verband met de sluitingsdata voor de belastingaangifte, onder hoogspanning werken. Vanuit de veronderstelling, dat hilerdoor de "stresses and tensions" min of meex geprovoceerd zouden worden, voorspelden zij 
dat in vergelijking tot rustiger perioden het cholesterolgehalte juist in die perioden zou toenemen en de bloedstoliing versneld zou worden. Beide voorspellingen werden door hun bevindingen bevestigd, met resp. $p<05$ en $p<01$ (Pxiedman e.a., 1958).

12.2.2 Definitie van het Type A- en Type B-gedrag, tesamen met enkele verschillen op somatisch nivo.

Deze resultaten voerden Exiedman er Rosenman tot de idee "to study people who were more or less continuously immersed in the same emotional complex that only occasionally involved the accountants" " Zij introduceerden toen het onderscheid in Type A en Type B als gedragstypen (Friedman e.a., 1959). Deze twee hoofdtypen worden ieder weer in twee sub-typen onderverdeeld, resp. A1, A2 en B3, B4, waarbij A1 en B4 de extreme prototypen en $A 2$ en $B 3$ de tussentypen van gedragspatronen aanduiden.

Iemand vertoont het Type Al-gedrag, "if he exhibited various signs we believed indicative of its presence, including excessively rapid bodily movements, tense facial and body musculature, explosive conversational intonations, hands or teeth clenching, excessive unconscious gesturing, and a general air of impatience, and if he admitted his sustained drive, competitiveness, and a necessity to accelarate many activities and was aware of a chionic sense of urgency in daily living". Als én van beide of beide laatste kenmerken afwezig zijn, spreekt men van "incompletely developed behavior pattern" of het Type A2-gedrag.

Iemand vertoont het Type B4-gedrag, "if an individual sat relaxedly, moved slowly and calmly, exhibited no muscular tension, spoke slowly, rarely undulged in tense gestures, exhibited no limpatience, avoided involvement in deadines, and felt no sense of urgency".

Men vertoont het Type B 3 -gedrag, wanneer er meer kenmerken van het Type B4-gedrag dan van het Type A2-gedrag aanwezig zi in.

Met behulp van een gestandaardiseerd interview, warbij op de Type A- en Type B-kenmerken wordt gelet, werd een groep samengesteld van 83 Type A-mannen (A1 + A2) en een groep van 83 Type B-mannen (B3 + B4). Bij een vergelijking van deze groepen kwamen 0. a. de volgende verschillen naar voren (Fiedman e. a. , 1959):

1. De Type A-manmen rookten gemidaeld meer sigaretten per dag dan de Type B-mannen. Ex worden echtex geen statistische toetsingsresultaten vermeld. 
2. De Type A-mannen vertoonden een hoger gemidala cholesterol gehalte dan de Type B-mannen. Hoewel at verschil als "significantly" wordt gekwalificeera, worden geen toetsingsresultaten vermeld.

3. De Iype Al-mannen vertoonden een gemiddelde bloedstolingstijd wan 6,8 minuten, de Type B4-mannen van 7,2 minuten. ook dit verschil zou "significant" zijn (eveneens zonder vermelding van toetsingsresultaten).

4. De prevalentie van arcus senilis bedroeg bij de Typo Amannen 38\%, bij de Type B-mannen $11 \%$.

5. Bij de Type A-mannen werden bij 23 mannen (28\%) "either clear-cut symptoms or definitive electrocardiographic signs of clinical coronary disease" gevonden, tegen 3 mannen (4\%) bij de Type B-mannen. Dit verschil in prevalentie is opvallend groot in vergelijking tot wat later bij een prospektief epidemiologisch onderzoek gevonden zal worden (zie 12.3.).

Deze gegevens wijzen alle op de relevantie van de $A / B$-typoLogie voor het onderzoek naar het ontstaan van cHz, althans bij mannen.

In 1961 verschijnt een studie van Rosenman e.a. (1961), waarin deze relevantie ook voor vrouwen wordt nagegaan. De resultaten, weergegeven in tabel 12.1. , wijzen erop

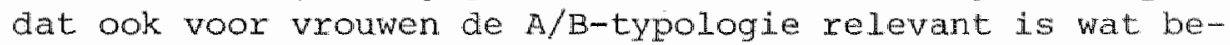
treft het onderzoek naar het untstaan van CHz.

In de lijn van de oorspronkelijke publikatie van Friedman en Rosemman werden in de daaropvolgende jaren een reeks van onderzoekingen gedaan naar zowel somatische- als gedragsverschilien tussen Type A- en Type B-personen. In tabel. 12.2. wordt hiervan een overzicht geboden.

12.3. De Western Collaborative Gxoup study (WCGS)

12.3.1. Indeling van de onderzoekspopulatie in Type A- en Type Bmannen met daarbij gevonden verschillen in prevalentie van coronaire hartziekten.

Bovengenoemde onderzoeksiljn nate de warde van de $A / B-t y p o-$ logie werd met een prospektief epidemiologisch onderzoek voorgezet in de zogenaamde western collaborative Gxoup Study (WCGS). Aan dit onderzoek, begonnen in 1960 door Friedman, Rosenman en medewerkers, verleenden aanvankelijk 11 bedrijven hun medewerking. In total werden 3524 mannen onderzocht, waarbij een aantal somatische variabelen gemeten werden (zoals cholesterol, lipoproteine, bloeddruk, ECG). Tevens werden kriteria opgesteld voor de medische diagnose: 


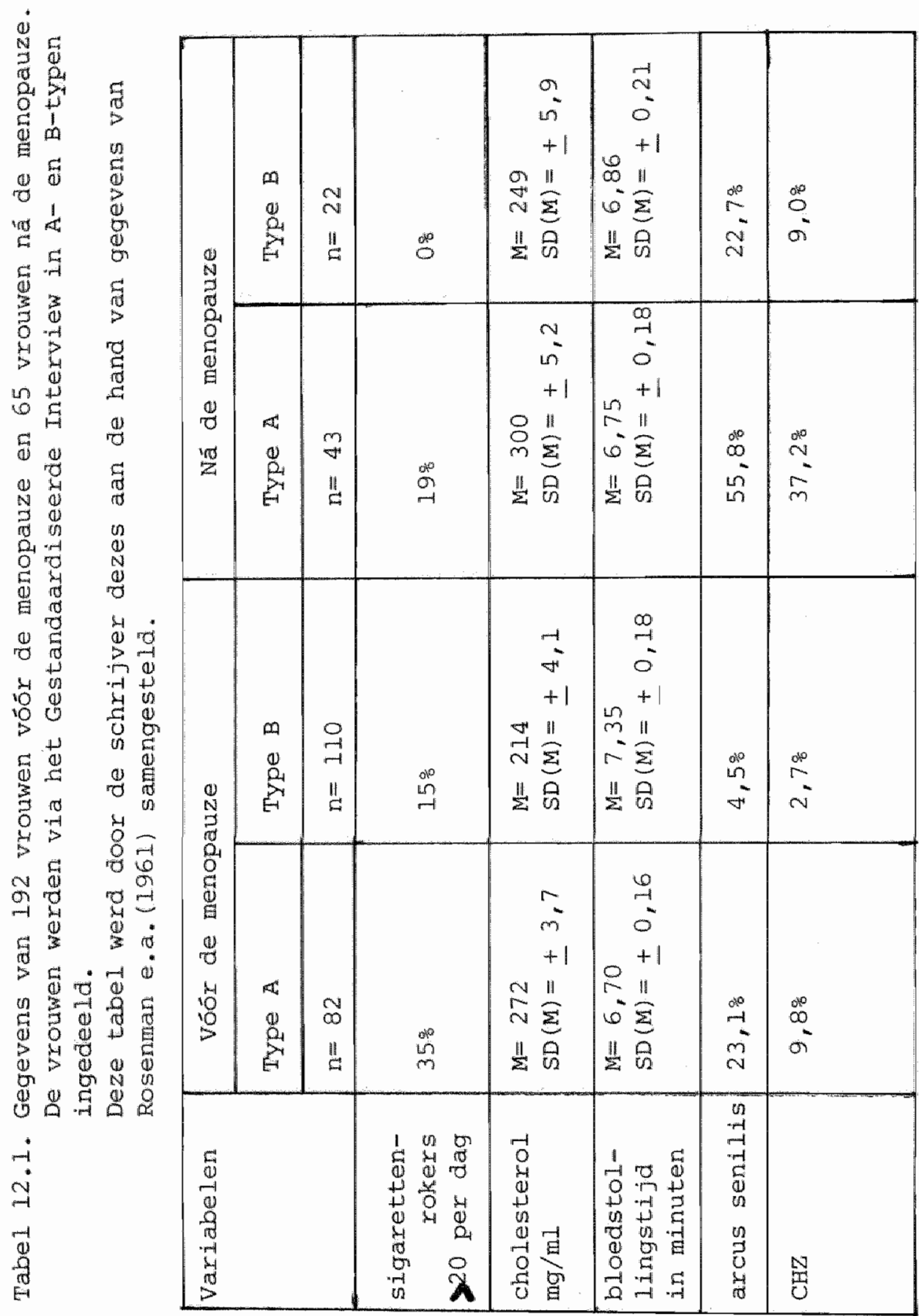




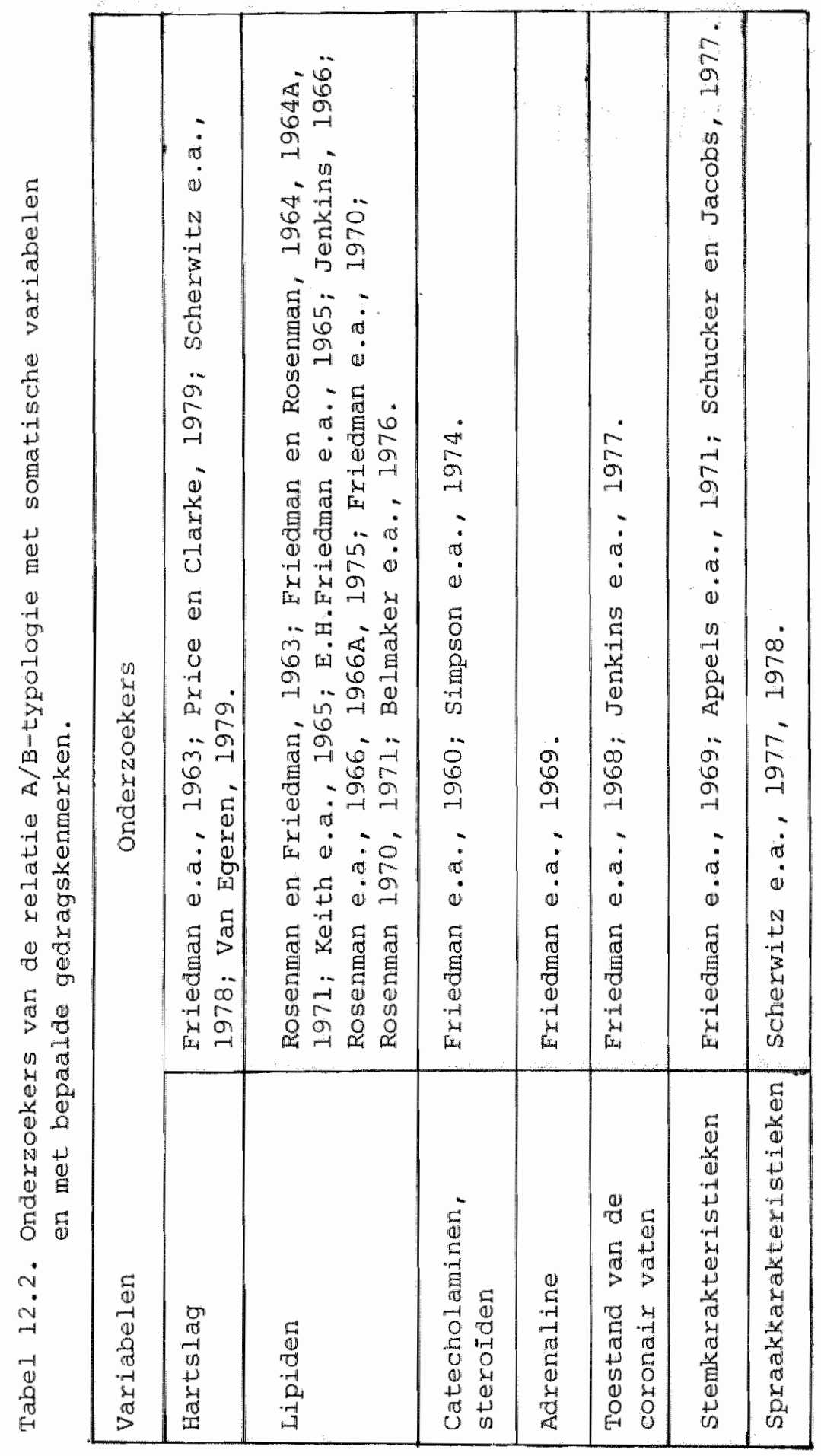


manifeste coronalre hartziekte (CHZ), waronder begrepen angina pectoris, hartinfarkt en "sudden death".

Alle mannen werden via het gestandaardiseerde interview ingedeeld in $A$ - en $B$-typen en in twee leettjosgroepen: een "jonge" groep (39 $t / m 49$ jaar) en een "oude" groep ( $50 \mathrm{t} / \mathrm{m}$ 59 jaar).

In tabel 12.3 staan resultaten vermeld, zoals die in 1960 voor deze mannen gevonden werden (Roseman e.a., 1964). Verwarrend in hun verslaggeving is dat de ene keer gesproken wordt over: "Manifest CHD was found in 113 of 3411 'wel1' men,..." en de andere keer over: "Manifest CHD was observed in 113 of 3524 subjects". Waarschijnlijk is dit de reden dat een aantal in tabel 12.3. vermelde waarden afwijkend van die van Rosenman e.a.(1964) zijn. Bij het samenstellen van die tabel is namelijk van de laatst genoemde numerieke gegevens uitgegaan, omat deze, gezien de hele verslaggeving het meest aannemelijk lijken.

Tabel 12.3 toont, dat zowel bij de "jonge" als bij de "oude" leeftijasgroep onder de Type A-mannen CHZ statistisch signifikant vakex voorkomen dan onder de Type B-mannen. De vraag is nu: blijft een dergelijk verschil in frekwentie ook bestaan bij een prospektieve onderzoeksopzet?

12.3.2. Incidentie van coronaire hartziekten bij Type $\mathbb{A}$ - en B-mannen, verkregen bij prospektief onderzoek.

In de tabellen 12.4. tot en met 12.7. staan resultaten vermeld, die gevonden werden bij 4 achtereenvolgende vervolgonderzoekingen. Daarbij komt naar voren, dat bij elk vervolgonderzoek CHz statistisch signifikant vaker voorkomt onder de Type A- dan onder de Type B-mannen, bij zowel de "jonge" als de "oude" leeftijdsgroep. Dit houdt in, dat het konstrukt van de A/B-typologie een zekere prediktieve validiteit bezit t.a.v. het ontwikelen van cHz.

12.3.3. Vergelijking van de prediktieve validiteit van de $A / B-t y p o-$ logie met die van enkele somatische risiko-faktoren.

Interessant is nu de vraag in welke verhouding de prediktieve validiteit van de A/B-typologie, op te vatten als een psychologische risiko-faktor, staat met die van somatische risiko-faktoren. In tabel 12.8. zijn ter vergelijking de gevonden risiko ratio's van 5 somatische risiko-faktoren en die van de A/B-typologie bij elkaar gezet, alle gebaseerd op $8^{\text {th }}$ jaar vervolgonderzoek. 


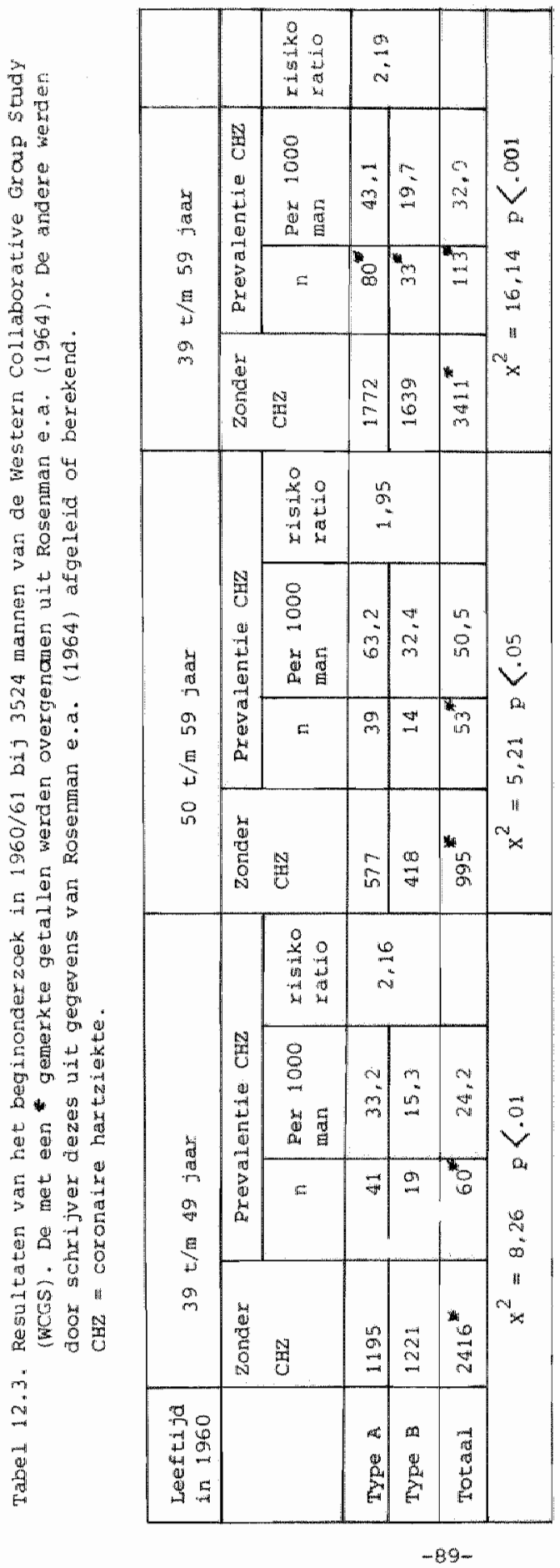



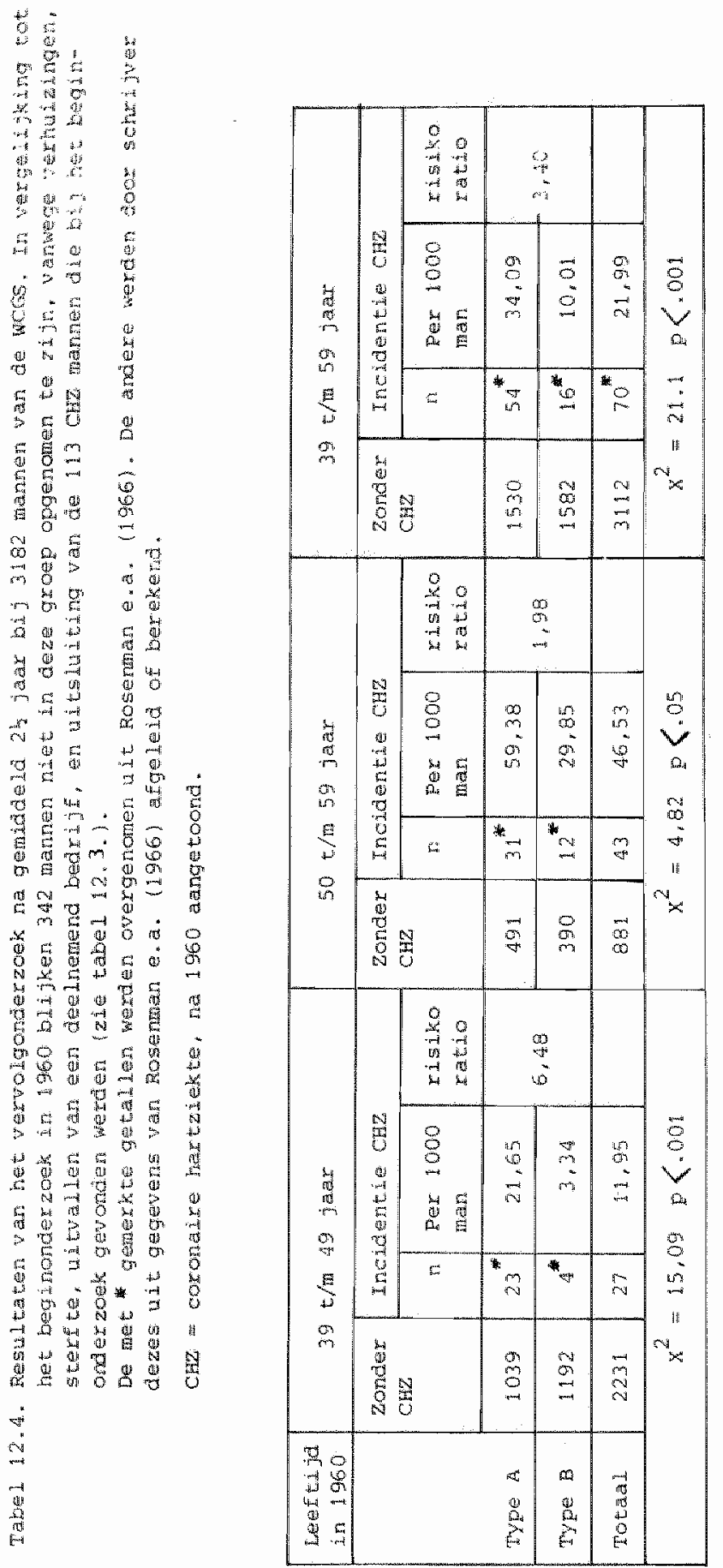

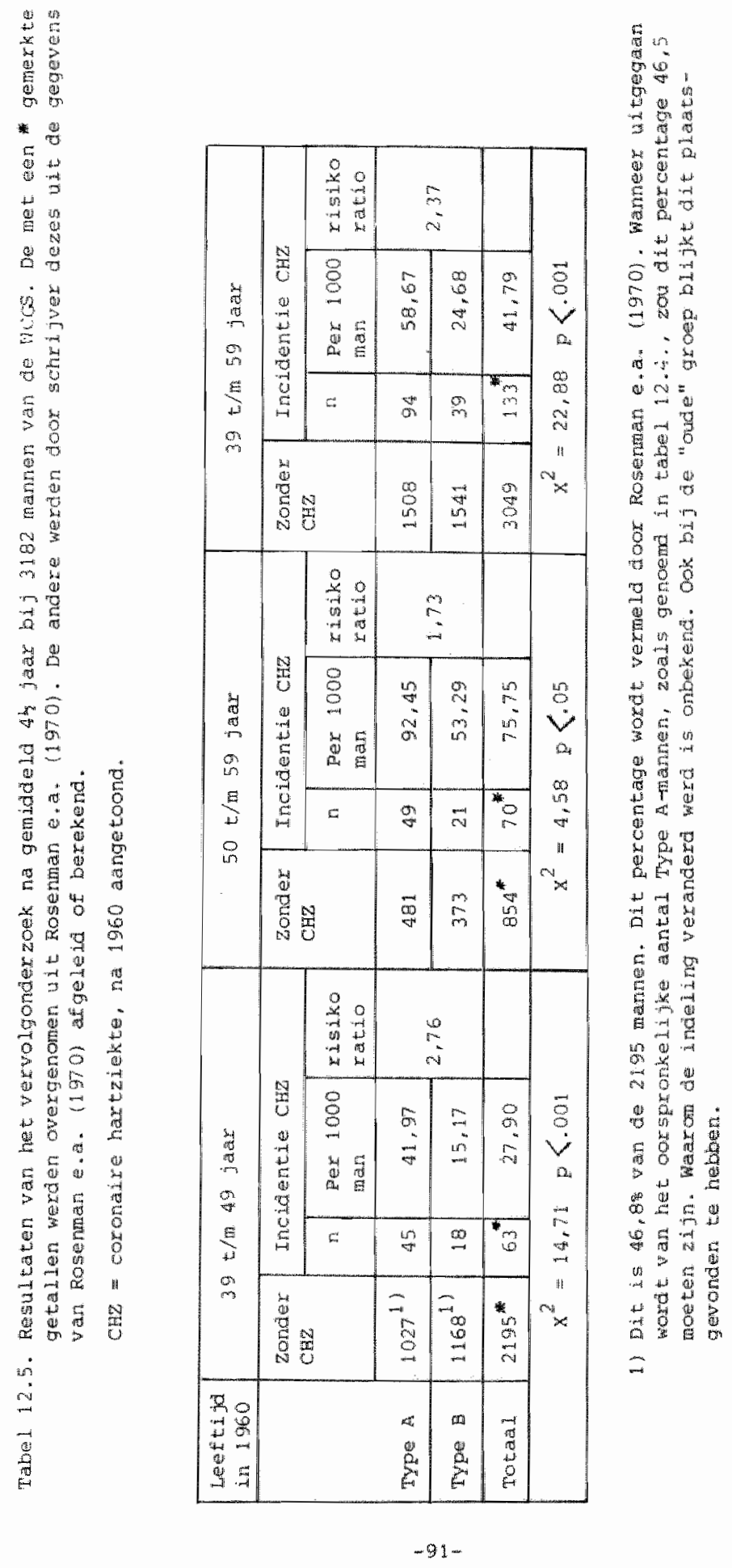


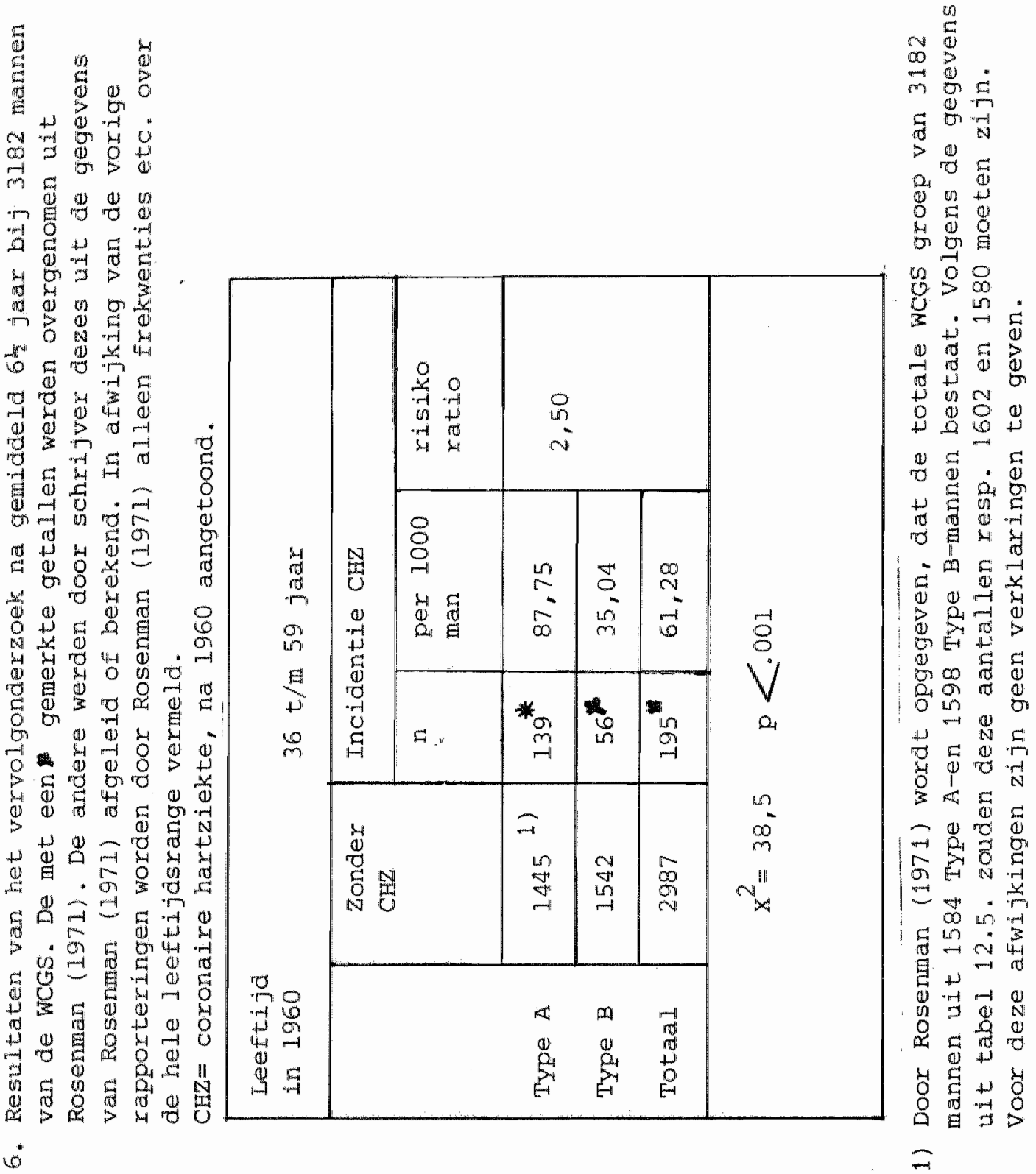




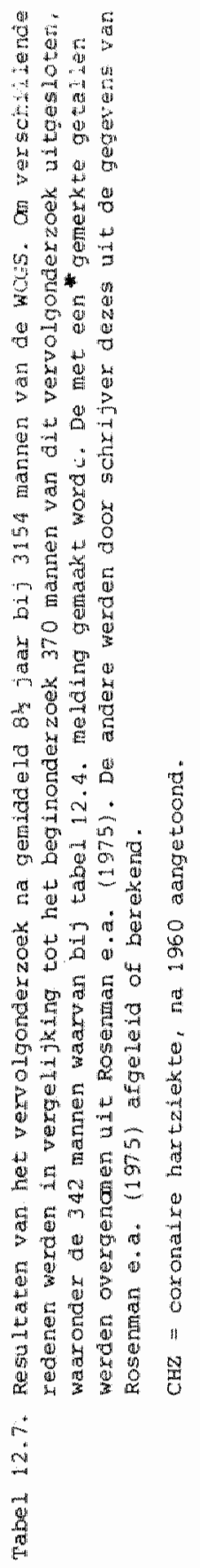

\begin{tabular}{|c|c|c|c|c|c|c|}
\hline \multirow{4}{*}{ 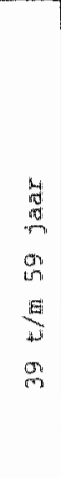 } & \multirow{3}{*}{ 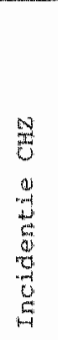 } & $\begin{array}{l}90 \\
40 \\
40\end{array}$ & \multicolumn{3}{|c|}{ in } & \multirow{4}{*}{$\begin{array}{l}\overrightarrow{8} \\
\dot{v} \\
0 \\
0 \\
0 \\
0 \\
0 \\
0\end{array}$} \\
\hline & & 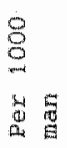 & $\begin{array}{l}8 \\
0 \\
\approx\end{array}$ & in & $\begin{array}{l}\infty \\
\square \\
\square \\
\square\end{array}$ & \\
\hline & & $E$ & $\stackrel{\infty}{\infty}$ & 8 & 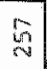 & \\
\hline & 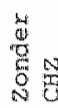 & & $\underset{\substack{-m \\
m}}{m}$ & $\begin{array}{l}\infty \\
\infty \\
\\
-1\end{array}$ & $\begin{array}{l}\mathrm{g} \\
\mathrm{g} \\
\sim\end{array}$ & \\
\hline \multirow{4}{*}{ 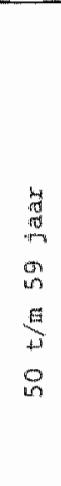 } & & 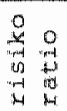 & \multicolumn{3}{|c|}{$\frac{\circ}{2}$} & \multirow{4}{*}{ 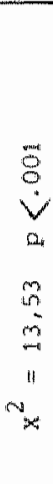 } \\
\hline & 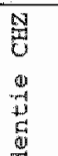 & 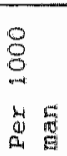 & $\underset{\substack{9 \\
i \infty \\
i \rightarrow 1}}{8}$ & $\vec{a}$ & 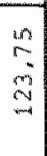 & \\
\hline & 总 & $=$ & ${ }^{*}$ & ${ }^{*} \Omega$ & 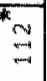 & \\
\hline & \multicolumn{2}{|c|}{ 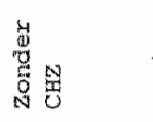 } & $\begin{array}{l}a \\
m \\
m\end{array}$ & $\underset{m}{m i n}$ & $\frac{m}{m}$ & \\
\hline \multirow{4}{*}{ 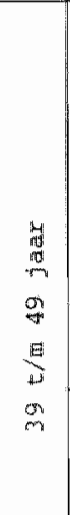 } & \multirow{3}{*}{ 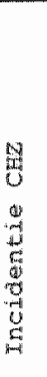 } & 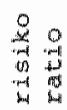 & \multicolumn{3}{|c|}{$\begin{array}{l}m-1 \\
\cdots \\
i\end{array}$} & \\
\hline & & 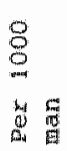 & $\underset{\infty}{\infty}$ & $\begin{array}{l}0 \\
8 \\
8\end{array}$ & s. & $\begin{array}{l}8 \\
8 \\
4\end{array}$ \\
\hline & & $\approx$ & ${ }^{*}{ }^{10}$ & 8 & 要 & 5 \\
\hline & \multicolumn{2}{|c|}{$\begin{array}{l}4 \\
0 \\
0 \\
0 \\
0 \\
0 \\
0\end{array}$} & $\stackrel{N}{Q}$ & $\begin{array}{c}w_{0} \\
m \rightarrow i \\
m-i\end{array}$ & $\underset{\mathrm{d}}{\mathrm{E}}$ & $\mathrm{r}^{18}$ \\
\hline 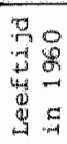 & & & ti & 政 & $\begin{array}{l}\overrightarrow{3} \\
\overrightarrow{4} \\
0 \\
0\end{array}$ & \\
\hline
\end{tabular}


Tabel 12.8. Risiko ratio"s, zoals gevonden bij het vervolgonderzoek na 8 is jaar van de WCGS. Het betreft de Hoog/Laag ratio's van 5 somatische risiko faktoren tesamen met de faktor: gedragstype. De ratio's werden door de schrijver dezes berekend uit gegevens van Rosenman e.a.(1975).

\begin{tabular}{|l|c|c|}
\hline \multirow{2}{*}{ Risiko faktor } & \multicolumn{2}{|c|}{ Risiko ratio } \\
\cline { 2 - 3 } & $39 \mathrm{t} / \mathrm{m} 49$ jaar & $50 \mathrm{t} / \mathrm{m} 59$ jaar \\
\hline $\begin{array}{l}\text { systolische } \\
\text { bloeddruk }\end{array}$ & 5,60 & 3,85 \\
\hline $\begin{array}{l}\text { diastolische } \\
\text { bloeddruk }\end{array}$ & 1,74 & 1,81 \\
\hline cholesterol & 4,26 & 2,52 \\
\hline triglyceriden & 3,22 & 1,96 \\
\hline $\begin{array}{l}\text { beta/alfa } \\
\text { lipoproteine }\end{array}$ & 2,07 & 1,72 \\
\hline A/B-typologie & 2,11 & 2,10 \\
\hline
\end{tabular}

Indien gemakshalve alle faktoren als statistisch onafhankelijk beschouwd worden dan blijkt, dat voor zowel de "jonge" als de "oude" groep de somatische faktor: systolische bloeddruk, de sterkste voorspellende waarde heeft. Voor de "jonge" groep neemt in de rij van 6 faktoren de A/B-typologie de te plaats in, bij de "oude" groep de $3 e$ plaats. Derhalve kan de faktor: gedragstype, als gelijkwaardig aan bepaalde somatische risiko-faktoren beschouwd worden, althans als het gaat om prediktieve validiteit.

12.3.4. De $A / B$-typologie als statistisch onafhankelijke risikofaktor.

De vraag blijft echter of de faktor: gedragstype, een onafhankelijke variabele is dan wel sterk gekorreleerd is aan somatische faktoren. Om hier inzicht in te krijgen werden door de onderzoekers de gegevens van de vervolgonderzoeken aan diverse statistische analyses onderworpen. 
Bij een analyse met twee variabelen blijkt ut de gegevens betreffende een vervolgperiode van 24 jaar, dat onder de "jonge" Type A-manner met diastolische hypertensie de gemiddelde jaarlijkse CHz-incidentie 24,7 o/00 1 s, onder de "jonge" Type B-mannen met diastolische hypertensie is dat 0 o/oo. Onder de "oude" Type A-mannen met diastolische hypertensie bleek 3,4 maal vaker een ckz te zijn voorgekomen dan onder de "oude" Type B-mannen met diastolische hypertensie (Rosenman e.a., 1966 A). Over de relatie van andere somatische risiko-faktoren met de faktor: gedragstype, berichtten Rosenman e.a. (1966 A): "Ir short, it is only when elevated diastolic bloodpressure or serum liplds or both accured in association with the type A behaviox pattern that these factors appeared to carry very marked prognostic significance".

$\mathrm{Na} 4 \mathrm{~s}$ jaar worden weer analyses met 2 variabelen uitgevoerd. Hierbij blijkt o.a. dat zowel de faktor: gedragstype, als de faktoren diastolische bloedaruk en cholesterol statistisch onathankelijke CHz-voorspellers zijn (Rosenman e.a., 1970). Om na te gaan of deze statistische onafhankelijkheid vexloren gaat wanneer meerdere risiko-faktoren tegelijkertijd statistisch gekontroleerd worden, werd een mitipele regressie analyse uitgevoerd, met invoering van 12 variabelen. Bij ce "jonge" groep bleek een signifikante korrellatie $(p=.002)$ tussen de faktor: gedragstype en CHz-incidentie, wanneer gekontroleerd werd voor de overige faktoren. De resultaten van de "oude" groep wijzen met een p-wadrde= .15 in dezelfde richting (Rosenman e.a., 1970).

Analyses, uitgevoerd op het materiaal na $8 \frac{1}{4}$ jaar vervolgonderzoek tonen hetzelfde beeld (Rosenman e.a., 1975;

Brand e.a., 1976).

Ook de gegevens van het prospektieve onderzoeksdee 1 van de WCGs wijzen dus op het bestaan van een statistisch signifikante relatie tussen het Iype A-gedrag en een verhoogd optreden van $\mathrm{CHZ}$, onathankelijk van bepalde somatische risiko-faktoren.

12.3.5. Betrouwbaarheid van het gestandaardiseerde interview.

Gezien de relevantie wan de A/B-typologie als Eaktor bij de ontwikkeling van CHz, dringt zich de vraag op naax de betrouwbarheid van het gestandaardiseerde interview bij de indeling in Type A- of B-personen. In dit verband kunnen een aantal onderzoekingen genoema worden. Door middel van beluistering van de gestandaardiseerde interviews van de eerste 25 WCGS-mannen, in 1960 
op de band opgenomen, deelde Jenkins (1968) deze mannen alsnog in in Type A1, $A 2, B 3$ en B4. Daarna vergeleek hij: zijn eigen indelingen met die zoals indertija door Rosenman gemaakt. Bij deze "verfignde" indeling was het overeenstemingspercentage 64:. Bij grove indeling naar Aen B-typen zonder meer werd van de 12 Type A-mannen volgens Rosenman doox Jenkins 100 hetzelfde getypeerd, van de 13 Type-mannen $69,2 \%$. De over all percentage-overeenkomst voor $\mathbb{A}$ en $B$ typering tesamen bedroeg 848 .

Friedman e.a. (1965) namen 107 advokaten o.a. het gestandardiseerde interview af en vroegen Rosenman deze personen te typeren volgens de A/B-typologie. Deze kwam tot 52 Type Aen 55 Type B-mannen. Twee onderzoekers uit de Friedman groep typeerden deze advokaten eveneens. De ene onderzoeker deed in 84,1: dezelfde typering, de andere in 80,48 van de gevallen. Hoeveel Type $A-$ en hoeveel Type B-mannen identiek geklassificeerd werden, wordt niet vermeld.

keith e.a. (1965) deelden patiënten, die opgenomen waren in een ziekenhuis, met behulp van het gestandaardiseerde interview in Type $A$ en $B$ in. Keith beluisterde 3 tot 18 maanden latex opnieuw een 100-tal van deze bandopnamen en deelde aan de hand daarvan deze patiënten opnieuw in. Het overeenstemingspercentage voor de "verfijnde" indeling bedroeg $57 \%$. Voor die in Typen A en B zonder meer 74\%. Er wordt niet vermeld om hoeveel Type A- en Type B-mannen, volgens de eerste indeling, het ging.

Op basis van diverse studies dienaangaande konstateren Jenkins e.a. (1968), dat bovengenoemde overeenstemmingspercentages niet ongunstig afsteken bij die, welke voor andere klinische beoordelingen gevonden worden.

\subsubsection{Stabiliteit van het Type A- of Type B-gedragspatroon.}

Blj dit alles doet zich ook de vraag voor naar de mate van stabiliteit van het getypeerde gedragspatroon.

Een onderzaek naar de stabiliteit van het getypeerde gedragspatroon werd gedaan door Jenkins e.a.(1968). De auteurs vermelden dat 595 Type A- en 469 Type B-mannen van de wCGS, als zodanig getypeerd in 1960, in 1962 an de hand van een tweede interview voor de tweede mal werden getypeerd. Van de Type A-mannen werd $78,7 \%$ en van de Type B-mannen werd 3.2,5: gelijkelijk getypeera (tetrachore korrelatiekoeffi-

- Het betreft hier Ermest H.Friedman en niet Mayer Friedman van de $A / B$-typologie. 
cient .82). Deze resultaten blijken niet veel af te wijken van bijvoorbeeld test-hertest gegevens van veel en alom gebruikte psychologische onderzoeksmethoden als de MMPI (welsh e.a., 1956) of de Wechslex-Bellevue inteligentietest (wechsler, 1958).

De relatief grote betrouwbaarheid van de typeringsmethode enerzijas en de relatief grote stabiliteit in de tija van het getypeerde gedragspatroon anderzijds, maken de uitslagen van de wCGS des te belangwekkender.

12.4. De Jenkins Activity Survey (JAS).

12.4.1. Inleiding.

Toch is het duidelijk, dat aan de methode A/B-typering door middel van het gestandaardiseerde intervatew en antal bezwaren kleven. Jenkins e.a. (1968) maken in dit verband de volgende opmerking: "Apart from the problem of training interviewers, the interview procedure itself is time-consuming and expensive in the large scale epldemiologic studies".

In 1967 werd door Jenkins e.a. dan ook de konstruktie van een vragenlijst beschreven "for measuring the coronaryprone behavior pattern". Deze test werd de Jenkins Activity Survey (JAS) genoemd.

12.4.2. Herkomst van de JAS-items en de konstruktie van de A/B-schaal.

De JAS bestaat uit 61 items, voomamelijk gebaseerd op vragen uit het gestandaardiseerde interview. De eerste versie, verder aan te duiden als JAS 1965, werd in 1965 aan de WCGS-mannen ter invuliling aangeboden.

Door $92 \%$ van deze mannen werd de JAS volledig ingevuld geretourneerd. In een volgende publikatie betreffende de JAS beschrijven Jenkins e.a. (1.971) de konstruktie van de zogenaande $A / B$-schaal, die tussen Type $A$ - en Type B-mannen diskrimineert. Met deze schaal werden 2960 JAs protokolien uit het WCGS bestand, geskoord. Het gemiddelde werd op 0 gesteld, met standaardaeviatie 10 .

Het diskriminerende vermogen van deze A/B-schal moge blijw ken uit tabel 12.9. De frekwentieverdelingen laten zien dat de schaal in het skore-middengebied onvoldoende tussen Type A- en Type B-mannen onderscheidt. Sub-groepen van zowel de Type A- als de Type B-mannen blijken zich echter op deze schaal relatief dujdelijk van elkar te onderscheiden. 


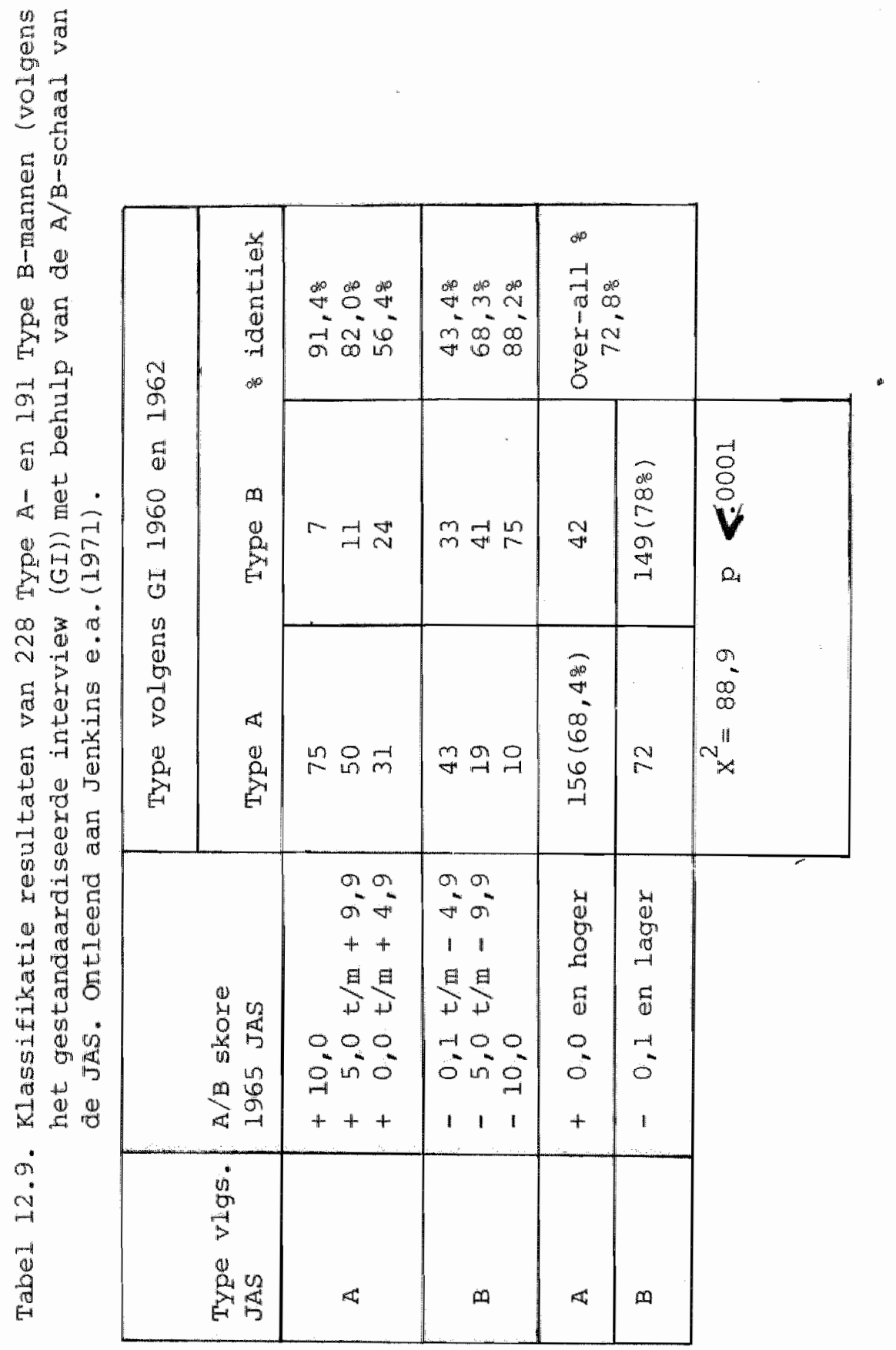


12.4.3. Faktoramalytische bevindingen bij de JAS.

In 1970 gaven Zyzanski en Jenkins een omschrijving van "Behavior pattern $A$ " en vervolgen: "The question arose whether this multifaceted behavior pattern, as described above, was really a single syndrome or a loose aggregation of traits or subsyndromes. Factor analysis is a method particularly geared to answer this type of question, and the JAS, composed of substantial series of individually scored items, lends itself well to this procedure".

Er werd een faktoranalyse uitgevoerd op het JAS 1965 materiaal van een steekproef van 707 WCGS-mannen. Inmiddels werd er ook een JAS 1966 samengesteld (Zyzanski e.a., 1970). Ook deze werd gefaktoranalyseerd met behulp van 984 protokollen van andere mannen uit de WCGS. Bij beide analyses kwamen dezelfde drie faktoren naar voren. De auteurs benoemden deze faktoren op grond van de inhoud van de relatief hoogladende items als volgt:

1. Faktor H(ard-driving), gedefinieerd door items die betrekking hebben op "hard-driving competitiveness and effort". "People scoring high on Factor $\mathrm{H}$ would seem to be well described by the slogan: "We try harder"".

2. Faktor J (ob-involvement). One of the consistently strong items deals with the amount of 'action' in one"s everyday life". "Men high on Faktor J may well seek out those vocational settings where intensive involvement in activity and the consequent rewards of high income, responsibility and prestige are the pattern".

3. Faktor s(peed and Impatience). "The items deal with speed, impatience and time urgency".

In tabel 12.10 staan test-hertest gegevens van de 4 JAS variabelen vermeld.

Het blijkt, dat er ook een JAS 1969 gekonstrueerd werd (Jenkins e.a., 1974), waarover, overigens zonder getallen te noemen, vermeld wordt: "The test-retest coefficients between the 1965 and 1969 forms administered at a fouryear interval are not appreciable lower than those between the 1965 and 1966 forms, given one year apart". De korrelatiekoëfficiënten tussen de drie faktoren onderling liggen voor zowel de JAS 1965 als de JAS 1966 tussen de .02 en .12.. Zie tabel 12.11. voor korrelaties tussen de JAS 1965 en JAS 1966, A/B-schalen en de drie JASfaktoren. 
Tabl 12.10. Text-hertest horrelatiekofficienten voor 3 JAs faktoren en de $A / B-5 c h a d$. Gekorreleerd werden de variabelen van de JAS 1965 met die van de JAS 1966 $(n=2699)$. Deze tabel werd door de schrijver dezes samengesteld aan de hand van gegevens van Zyzanski e.a. (1970) en Jenkins e.a. (1971).

\begin{tabular}{|l|c|}
\hline Faktor & test-hertest \\
JAS 1965 versus & korrelatie \\
JAS 1966 & koefficient \\
\hline J & .60 \\
S & .67 \\
A B B-schaal & .70 \\
\hline
\end{tabular}

Tabe1.12.11. Korrelatiekoëfficjënten tussen de JAS $1965 \mathrm{~A} / \mathrm{B}-\mathrm{scha} a \mathrm{l}$ en de arie JAS-faktoren en tussen de JAS 1966 A/Bschaal en de drie Eaktoren, samengesteld aan de hand van gegevens van Jenkins e.a. (1971)

\begin{tabular}{|c|c|c|c|}
\hline A/B-schaal & Faktor $\mathrm{H}$ & Faktor J & Faktor $\mathrm{S}$ \\
\hline JAS 1965 & .34 & .34 & .51 \\
JAS 1966 & .40 & .23 & .50 \\
\hline
\end{tabular}

12.4.4. Coronaixe hartziekten en JAs-resultaten bij retrospektief onderzoek.

Jenkins e.a.(1971) vermeldden, dat van de 2960 WCGS-mannen, die de JAS 1965 invulden, er 83 na het eerste screeningsonderzoek in 1960 een eerste aanval van diagnostisch geverifieerde $\mathrm{CHz}$ ontwikkelden. Gezien de theorie zouden 
deze mannen op de $\mathrm{A} / \mathrm{B}-\mathrm{schaa}$ en de faktoren $H$, it en $\mathrm{S}$ van de JAS hoger moten skoren dan de mannen, die binnen hetzelfae tijdsbestek geen CHz ontwikkeld hadden.

Zowel de $A / B-s c h a a l$ als JAS-faktor $H$ bijiken een redelijke gelijktijaigheidsvaliditeit ten aanzen van crz te bevatten.

12.4.5. Coronaire hartziekten en JAS-resultaten bij prospektief onderzoek.

Voortgaande in de lijn van hun onderzoeksvraagstelingen rapporteerden Jenkins e.a. (1974), dat er zich bij 2750 mannen van de WCGS, die in 1965 de JAS 1965 invulden, in de voorafgaande jaren geen coronaire hartziekten ontwikkeld hadden. Voor het einde van 1969 echter bleken 120 van deze mannen een $\mathrm{CHZ}$ ontwikkeld te hebben. Noor deze $120 \mathrm{CHZ}-$ mannen geldt, dat de wijze van invulien van de JAs niet beinvloed geweest kan zijn door het doorgemaakt hebben van een CHz met de gevolgen van dien. Bij een vergelijking van hun JAS-skores met die van een kontrolegroep blijkt, dat alleen de $A / B-s c h a a l$ een prediktieve validiteit bezit. Dit brengt Jenkins e.a.(1974) tot de uitspraak, dat "the coronary-prone behavior pattern is prospectively linked to the pathogenesis of CHD".

De prediktieve validiteit van de $A / B-s c h a d$ blijkt voorts uit het gegeven, dat met het stijgen van de gemiddelde A/B-skore ook de gemiddelde jaarlijkse CHz-incidentie stijgt, zowel bij de "jonge" als de "oude" groep mannen.

12.4.6. De prediktieve validiteit van de $A / B$-schaal van de JAS op individueel voorspellingsnivo.

Jenkins e.a. (1974) publiceerden een tabel waruit blijkt, dat 840 mannen $(30,5$ van de 2750 mannen, de lin 1965

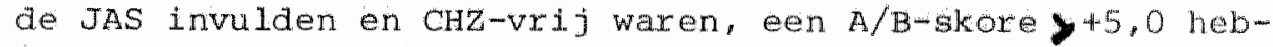
ben en derhalve uitgesproken "coronary-prone" zijn.

De gemiddelde A/B-skote van de 120 CHz-mannen, zoals vermeld in 12.4.5. is $+1,70$ (Jenkins e.a. "1974). Hierult kan worden afgeleid, dat van de 840 mannen, die volgens de A/B-schaal "coronary-prone" zijn, (gelukkig !) slechts een gexing percentage in de loop van 4 jaar een criz ontwkkela heeft. Deze vier jaar echter dient wel als een korte tijd te worden aangemerkt.

Voor de praktijk blijkt de A/B-schaal, als voorspeller op individueel nivo, vooralsnog onvoldoende. 
In 1978 geven Jenkins e. a. een aanwijzlng voor een mogelijke verklaring van de geringe voorspellende waarde van de $A / B-$ schal ten aanzien wan het ontwikkelen van CHz. Naar aanlejalng van een ltemanalyse bij de JAS, warbij ten aamien van de klinische manifestatie van de chz onderscheid wordt gemakt in: akuut infarkt, "stil" infarkt lalleen volgens het ECG, zonder subjectieve klachter) en angina pectoris, delen zij mede: "Item analysis of the questionnaire using multigroup optimal scaling and discriminant function revealed the pattern of resporse to be characteristically aifferent among the three clinical presentations of coronary disease and the men who remained healthy" .

Deze bevinding is gebaseerd op de tijdsdwur van 4 jaar van de WCGS. Het is dus de vraag, of het "coronary-prone behavior pattern" niet eerder als een meervoudig dan als een enkelvoudig patroon mot worden opgevat. Hun antwoord op de vraag 1uidt: ".. there may be at least two, possible three, behavioral patterns associated with future emergence of aifferent clinical manifestations of CHD" (Jenkins e.a., 1978).

zo gezien is de geringe prediktieve warde van de $\mathrm{A} / \mathrm{B}-$ schal van de JAS minder verwonderlijk, gegeven het ongenuanceerd gebruik van de ruime diagnostische kategorie cHz.

12.5. De Nederlandse versie van de JAs.

12.5.1. De konstruktie van de Nederlandse A/B-schaa1.

In verband metonder andere een cross-kultureel screeningsonderzoek naar operationele en gedragswetenschappelijke aspekten op het terrein van hart- en vaatziekten, werd de JAS door Appels in het Nederlands vertaald en uitgeprobeerd (Appels e.a., 1979). Bij diens konstruktie van de Nederlandse A/B-schaal. werd als kriteriun gebruik gemaakt van Iype A1-, A2-; A/B- (middenkategorie), B3- en B4-mannen, getypeerd met behulp van het gestandaardiseerde interview. Van de 61 Amerikaanse items werden ex op grond van hun discriminerende vermogen 36 gebruikt voor de konstruktie van de Nederlandse $A / B-s c h a d$. De scores op deze schal werden genormaliseera, met als gemiddelde 0 en standaarddeviatie 1,00 .

Bij ordening van de 5 kriteriumgroepen van Al tot B4 ziet men de gemiddelde $A / B$-skore, geheel volgens verwachting, systematisch lager worden. 
In tabe1 12.12 kan gelezen worden, in welke mate de Nederlandse A/B-schaal de typeringen met behulp van het gestandaardiseerde interview (GI) repliceext.

Tabe1 12.12. Indelingen volgens de A/B-schal van de Nederlandse JAS en die volgens het gestandaardiseerde interview van 258 mannen, samengesteld aan de hand van gegevens van Appels e.a. (1979).

\begin{tabular}{|l|r|r|r|c|}
\hline \multirow{2}{*}{ JAS Type } & \multirow{2}{*}{ JAS } & \multicolumn{3}{|c|}{ Volgens interview } \\
\cline { 3 - 5 } & A/B-skore & Type A & Type A/B & Type B \\
\hline A & +.50 & $65(68 \%)$ & 27 & 8 \\
\hline A/B & +.50 & 25 & $27(39 \%)$ & 16 \\
\hline B & -.50 & & 14 & $70(74 \%)$ \\
\hline
\end{tabular}

Van de 96 Type A-mannen volgens het GI worden er 65 "juist" geklassificeerd. Dit is $67,7 \%$. Van de 94 Type B-mannen 70 . Dit is 74,58. Van de 68 Type A/B-mannen wordt 39,78 "juist" geklassificeerd, hetgeen de over all percentage-overeensteming op 62,8 brengt.

In tabel 12.9. kan gelezen worden, dat in Amerika voor de Type A-mannen in $68,4 \%$ en voox de Type B-mamnen in 78 : van de gevallen overeenstemming gevonden wordt. Zo berekend Iiggen de Nederiandse en de Amexikaanse overeenstemmingspercentages in dezelfae orde van grootte.

In Amerika werkt men echter niet met een muddentype tussen A2 en $B 3$ en juist deze kategorie makt het over-all overeenstemingspercentage in Nederland relatief laag: 62,03 . Wordt deze kategorie weggelaten, dan worden er van de (258 minus $68=$ ) 190 proefpersonen 135 "juist" geklassificeerd $(718)$. Dit pexcentage komt vrijwel. overeen met dat wat in Amerika gevonden werd, namelijk $72,8 \%$.

Appels e.a. (1979) doen het in hun publikatie voorkomen. alsof de Nederlandse versie van de $A / B-s c h a a l$ van de JAS in $91 \%$ van de gevallen $A$ - en B-typen (volgens het GI) kan identificeren. Wat deze auteurs echter bij het berekenen van dit percentage gedaan hebben, is het weglaten van de middenkategorie voor zowel de JAS-skores als wel de typering 
volgens het GI. Er wordt dan gesteld: van de 71 Type $A-$ mannen zijn ex 65 "juist" en van de 78 Type B-mamnen zijn er 70 "juist", dus 135 van de 149, af te wel $91 \%$. Deze wijze van berekenen geeft echter een zeer geflatteera beeld. Immers, stel dat men met de JAS Type A-en Type B-marnen opspoort (aaarvan moet men in de praktijk toch uitgaan), dan zou men hooguit over mannen uit de JAS-middenkategorie geen uitspraak kunnen doen. Volgens de $A / B-s c h a a l$ behoren dan 100 mannen tot het A-type en 90 tot het B-type. Over 190 van de 258 mannen of wel $73 \%$ van de mannen ult de onderzoeksgroep wordt dan echter een uitspraak gedaan. Voor de A-typen wordt dan een overeenstemingspercentage gevonden van 65\%, bij de B-typen var 77, 8\%, met als over-all percentage: $71 \%$, en niet het geflatteerd berekende percentage van 91. Bekijkt men de gegevens uit tabel 12.9. en laat men de Jas-middenkategorie weg $(A / B-s k o r e s$ vanaf $+0,0 \mathrm{t} / \mathrm{m}-4,9)$, dan wordt er een uitspraak over $68,7 \%$ van alle proefpersonen gedaan. Het overeenstemingspercentage is woor de A-typen dan 85,6 en voor de B-typen $75 \%$. Vooralsnog $11 j \mathrm{kt}$ de Amerikaanse versie wan de JAS beter Type A-mannen te identificeren dan de Nederlandse, voor de B-typen ligt dit voor belde versies ongeveer gelijk.

\subsubsection{Over de validiteit van de Nederlandse $A / B-s c h a a 1$.}

Appels e.a. (1979) vermelden ook gegevens over de gelijktijdigheidsvaliditeit van de $A / B-s c h a d$. Een groep van 143 mannen onder behandeling wegens cardiovasculaire problemen vertoont een hogeregemiddelde $A / B$-skore dan de kontrolegroep ( $\mathrm{p}<.01)$, evenals een groep van 149 patienten met angina pectoris $(\mathrm{p}<.05)$. Een groep van 116 manmen met een oud infarkt vertoont geen statistisch signifikant hogere gemiddelde $A / B-s k o r e$ in vergelijking tot de kontrolegroep. De eexste twee uitslagen wijzen er dus op, dat de Nederlandse A/B-schaal enige, op cardiovasculair gebied, relevantie heeft. voor de verklaring van de afwezigheid van een signifikant verschil in $A / B-s k o r e s$ tussen hen die wel en hen die geen haxtinfarkt hebben doorgemakk, voeren de onderzoekers onder andere aan:

a. dat de ingrijpende gebeurtenis van het infarkt gemakkelijk tot veranderingen irı het (test)gedrag leidt;

b. een restriction of range. Growweg 30: sterft onmidallijk tengevolge van het hartinfarkt.

Ex werden geen signifikante korrelaties gevonden tussen de Nederlandse A/B-schal en diastolische en systolische bloeddruk, cholesterol en leeftija. Wel wordt een positieve 
korrelatie gemeld van deze nederlandse schal met socianlekonomische status, overigens zonder vermelding van het signifikantienivo.

12.6. Wederzijdse herkenbaarheid van de JAS-en de BuL-faktoren.

12.6.1. Herkenbaarheid van de JAs-faktoren bij de BUL.

Het ligt in de lijn der verwachtingen bij JAS en BUI min of meer overeenkomstige dimensies aan te treffen. Het Type Agedrag is immers gekorreleerd an de predispositie tot $c . q$. het bestaan van een CHz, terwijl de BUL betrekking heeft op "specifieke" kenmerken van 0.a. hartinfarktpatienten. Voor JAS-faktor $S$ (peed and Impatience, zie 12.4.3.) is bij de BUL niet zonder meer een ekwivalent te vinden. ook op item-nivo zijn bij de BUL niet of nawwelijks herkenningspunten voor deze hast-en ongedulasfaktor aanwijsbaar.

De JAS-faktoren B (ard-driving) en J(ob-involvement, zie 12.4.3.) zijn herkenbaar in de BUL-Eaktoren III (Activiteit en werken), IV (Eerzucht/Dominantie) en VI (Beroepsverantwoordelijkheid).

12.6.2. Herkenbaarheid van BUL-faktoren bij de JAS.

Voor BF-I (Agressiviteit) is bij de JAS geen ekwivalent aanwijsbaar. Zyzanski e.a. (1970) stellen echter wel dat "manifest hostility" een aspekt is van het Type A-gedrag. Dat dit aspekt bij de JAS niet als afzonderlijke faktor naar voren komt, zou kunnen samenhangen met het feit, dat bij de JAS hostiliteits-items in mindere mate vertegenwoordigd zijn dan bij het gestandaardiseerde interview (zyzanski. e.a., 1970). Wellicht is bij de BuL het antal 1tems dat op "manifeste hostiliteit" (agressiviteit) betrekking heett, meer adekwat gekozen.

Dat bij de JAS voor BH-II (Depressiviteit) geen ekwivalent aanwijsbaar is, is niet verwonderlijk, aangezien binnen de A/B-typologie een dergelijke komponent niet voorkomt. Hetzelfde geldt voor het ontbreken in de JAs van een ekwivalent voor $B F-V$ (Sociabiliteit), aangezien ook dit konsept

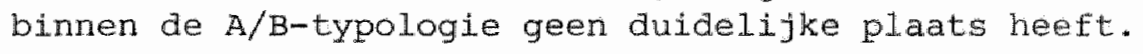

Wie 2.3.3. in verband met de grote lading van leeftija en opleidingsnivo op deze BF-IV 
12.7. Een vergelijkend onderzoek tussen Type A- en Type B-mannen met behulp van de BUL.

\subsubsection{Inleiding.}

In het voorafgadnde is naar voren gekomen, dat het Type Agearag, vastgestela hetzij met behulp van het gestandaardiseerde interview, hetzij met de $A / B-s c h a d$ van de JAS, statistison signifikant aan CHZ gekorreleerd is.

Dit betekent, dat er dan op zijn minst een grote mate van overeenkomst moet bestaan tussen kenmerken van het Type Agedrag en persoonlijkheids- en gedragskenmerken, die voor hartinfarktpatiènten beschreven zijn.

Blj een nadexe witwerking hiervan zal uitgegaan worden van een omschrijuing die door Jenkins e.a. (1976) gegeven

werd: "Type A behavior is characterized by excess of being hard driving, competitive, conscientious, hurried, impatient, aggressive and striving for vocational and social achievement".

Het kenmerk "aggressive" wordt in verschillende bewoordingen frekwent aangetroffen in persoonlijkheids- en gedragsbeschrijvingen van hartinfarktpatiënten (zie 3.2.1.).

De karakteriseringen "excess of being hard driving, competitive, conscientious" worden ook frekwent aangetroffen (zie 5.1.1.).

Het tot het Type A-gedrag behorende kenmerk "striving for vocational and social achievement" is bij "Treurniet (1965) terug te vinden, war hij over hartinfarktpatiënten schrijft: "In de wijze van actief zijn imponeert een brandende eerzucht".Groen en Van der Valk (1965) rapporteren in dit verband "rhey have to show they are doing their work better than others". Ook door Arlow (1945) en Dunbar (1948) wordt een soortgelijk kenmerk als typerend beschreven.

Met de hierboven gekonstateerde grote mate van overeenstemming van kenmexken bij hartinfarktpatiènten en rype $A-$ manner 19 tevens gegeven, dat bepalde overeenkomende kenmerken dan ook meetbax moeten zijn met de BUL. zo kan er redelijkerwijs verondersteld worden, dat het "aggressive"kenmerk uit de A/B-typologie meetbaar is met BF-I (Agressiviteit), het kenmerk "excess of being hard driving, competitive, conscientious" met BF-III (Aktiviteit en werken) en het kenmerk "striving for vocational and social achievement" met BE-IV (Eerzucht/Dominantie) .

- op het gegeven van de hoge ladingen op deze BF-IV van leeftijd en opleiding zal nader ingegaan worden. zie ook 2.3 .5 . 
Dit biedt de mogelijkheld om de warde van het gestandardiseerde interview als basis voor de typering in $A$ of $B$ te onderzoeken met behulp van een objektieve methode "die geheed onafhankelijk wan de $\mathbb{A} / B$-typologie ontwikkeld werd.

\subsubsection{Hypothesen}

Uit de veronderstelingen, dat Type A-mannen, in vergelijking tot Type B-mannen, meer "aggressive" en "hard ariving" 21 in en meer gericht zijn op "striving for vocational and social achievement", zijn de volgende toetsbare hypothesen af te leiden:

Hypothese 1. Type A-mannen geven op BF-I meer agressiviteit aan dan "Type B-mannen.

Hypothese 2. Type A-mannen geven op BF-III een hogere mate van positieve waardering aan voor aktivitejt en werken dan Type B-mannen.

Hypothese 3. Type A-mannen geven op BF-IV meer eerzucht en dominantie aan dan Type B-mannen.

12.7.3. Proefpersonen.

Het toetsen van bovengenoende 3 hypothesen werd mogelijk gemaakt door de medewerking van kollega Appe 1s*. Deze leerde in 1971 van Friedman en Rosemman de techniek van het gestandaardiseerde interview en de hierop gebaseerde typering van personen in Type $A$ of $B$. Onder andere om hierin meer ervaring op te doen nam Appels dit interview af bij 156 mannen van het Rotterdamse Shell bedrijf en typeerde deze mannen vervolgens als Type $A$, Type $B$ of als "niet te klassificeren". Van deze 156 mannen vulden er 87 de BUL volledig in. Van deze 87 mannen bleken er 36 te zijn getypeerd als Type $A, 29$ als Type $B$ en 28 als "niet te klassificeren". In het onderhavige onderzoek zullen deze 28 mannen verder buiten beschouwing worden gelaten. De typering door Appels vond volkomen onafhankelijk van BuL-skores plaats. De gemiddelde leeftija van de Type A-mannen is 44,2 jaar (SD 4,6 jaar), van de type $\mathrm{B}-$ mannen 43,2 jaar (SD 4,5 jaar). Van deze mannen is geen informatie voorhanden aangaande hun socio-ekonomische status of opleidingsnivo. Wel bekend is dat de meesten van hen bij shell een kursus voor "operator" volgaen.

* Met dank aan Dx. Appe1s, destijas wexkzaan aan de Exasmus Universiteit te Rotterdam, thans in de Capaciteitsgroep Medische Psychologie van de Rijksuniversiteit Iimburg. 
12.7.4. Voorspelingen, toetsingen en resultaten.

Uit de in 12.7.2. geformuleerde hypothesen worden de volgende voorspellingen afgeleid:

In vergelijking tot de 29 Type B-mannen skoren de 36 Type Amannen:

- hoger op BF-I, dat wil zeggen meer in de agressiviteitrichting (Voorspelling 1 );

- lager op BF-III, dat wil zeggen meer in de aktiviteit en werken-richting (Voorspelling 2);

- lager op BF-IV, dat wil zeggen meer in de eerzucht en dominantie-richting (voorspelling 3)."

Voor de toetsingen werd gebruik gemaakt van de U-toets van Mann-Whitney (Siegel, 1956). Als signifikantienivo wordt 5\%, eenzijdig, aangehouden.

Zle voor de toetsingsresultaten tabel 12.13.

12.7.5. Onderzoeksbevindingen en diskussie.

1. Uit de toetsingsresultaten kan gekonkludeerd worden, dat alle drie voorspellingen uitgekomen zijn, waarmee de drie hypothesen gesteund zijn. De afwijking van de pwaarde van het $5 \%$ nivo van voorspelling 2 is namelijk zo minimaal, dat ook hypothese 2 wel gesteund geacht kan worden.

Met behulp van een objectieve methode, die onafhankelijk van de $A / B$-typologie ontwikkeld werd, blijken vanuit deze typologie verwachte verschillen tussen Type $A_{-}$- en B-mannen dus aantoonbaar. Dit pleit voor de aanname, dat het mogelijk is om met behul.p van het gestandaardiseerde

In 2.3.5. werd genoemd, dat de variabelen leeftija en opleiding relatief het hoogste op $B F-I V$ laadden. In het onderhavige onderzoek zijn deze beide variabelen bij de skoring op $\mathrm{BF}-I$, III en IV buiten beschouwing gelaten.

Aangezien de 36 Type A-mannen en de 29 Type B-manmen in gemiddelde leeftijd slechts éen jaar verschillen, lijken de toetsingsresultaten door de variabele leeftijd weinig of niet beinvloed te kunnen zijn. Een invloed van de variabele opleiding is echter niet te schatten. De skores op BE-IV zijn altijd van een positief teken voorzien.

Een relatief lage skore korrespondeert inhoudelijk met mér eerzucht en dominantie. 


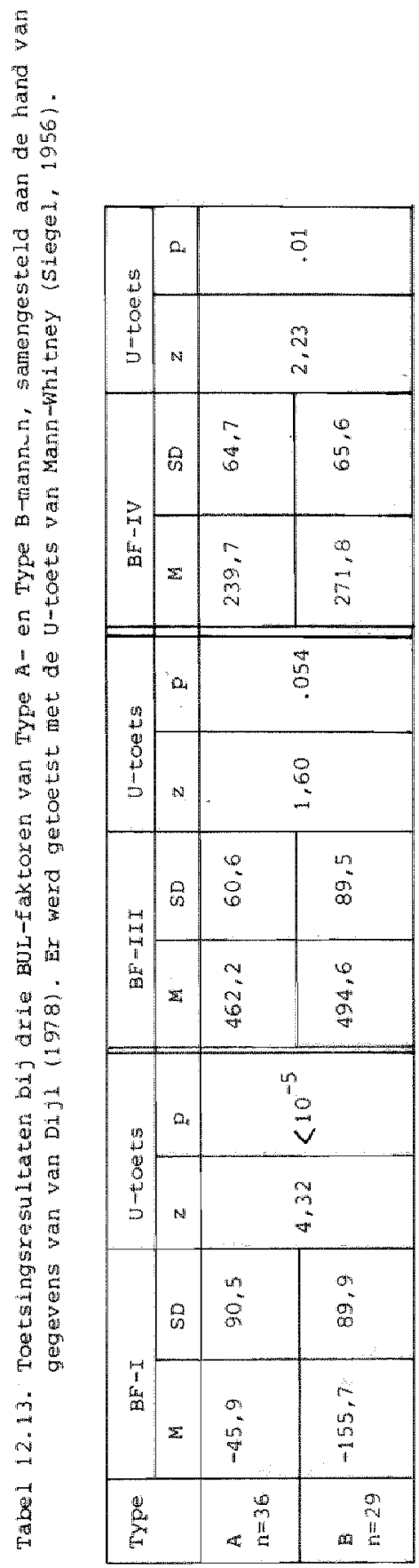

$-109-$ 
Interview de "sterkte" van een aantal kruciale kenmerken van het Type A-gedragspatroon te schatten.

2. Bif dit alles werd ex stilzwijgend vanuit gegaan, dat de gebrulkte onderzoeksvariabelen yalide zijn. Dit is gebaseerd op de toetsingsuitsiagen van de in de hoofdstukken 9,10 en 11 beschreven onderzoekingen.

Immers, in persoonlijkheids-er gedragsbeschrijvingen van hartinfarktpatienten worden frekwent een verhoogde mate van agressiviteit en hyperaktiviteit als belangrijke kenmerken genoemd. Als groepen hartinfarktpatiënten en "gezonden" op BF-I (Agressiviteit) en BF-III (Aktiviteit en werken) bij herhaling inderdaad een skoreverschil in de verwachte richting laten zien, kan dit als een indikatie voox de validiteit van deze BUL-faktoren gezien worden.

Van BF-IV (Eerzucht/Dominantie) valt in dit verband te vermelden, dat de groep van 102 niet-gehospitaliseerde hartinfarktpatienten, in vergelijking tot de kontrolegroep van "gezonde" mannen, zeer signifikant hoger in de Eerzucht/Dominantie richting skoort $(\mathrm{p}<.0001$, een$z i j d . j g)$. Bij een vergelijking van de groepen van 98 en 63 hartinfarktpatiënten met hun kontrolegroepen van "gezonde" mannen werden ook verschilien in de verwachte richting gevonden, doch verre van statisch signifikant (resp. $p=.38$ en $p=.26$, eenzijaig). Het gegeven dat de patienten uit deze laatste twee groepen in een ziekenhuis opgenomen waren toen zij de BUI beantwoordden, kan hierbij van invloed zijn geweest. In deze onderzoekingen werd dus geen duidelijke steun gevonden voor de aanname van validiteit van BF-IV.

Echter, de toetsingsresultaten verkregen met het BULonderzoek bij de Type $A$ - en de Type B-manner kunnen evenzeer gezien worden als steun voor de validiteitsaanname van de BUL-Faktoren I, III en IV. Gedurende het gestandaardiseerde interview en latex bij de hierop gebaseerde indeling van de proefpersonen in $A^{\prime}$ 's en $B^{\prime} S$ werd namelijk juist gelet op onder andere de mate van agressiviteit. aktiviteit en eerzucht. Op grond van de klinische beoordelingskategorieen $\mathrm{kan}$ an ook verwacht worden dat Type A-mannen, in vergelijking tot Type B-mannen, agressiever, aktiever en eerzuchtiger zijn.

Aangezien de Type A-mannen op BF-I, III en IV hoger skoren (in de verwachte richting) dan de Type B-mannen, lijkt de kans dan ook groot dat deze BuL-faktoren geschikte objektiveringen vormen voor de klinische beoordelingskategorleën, met andere woorden, als daarvoor valide 
variabelen beschouwd kunnen worden.

3. De uit de wCGS naar voren komende verhoogde kans op CHz bij Type A-personen makt het waarschijnlijk dat de Burfaktoren I, III en IV een preaiktieve validiteit hebben ten aanzien van het ontwikkelen van deze aandoening. Het gegeven, dat geen der proefpersonen van het shellonderzoek een $\mathrm{CHz}$ heeft doorgemaakt, makt de onderzoeksresultaten des te belangwekkender, aangezien de wijze van beantworden van de BUL niet beinvloed kan 2 ijn door het doorgemaakt hebben van deze ziekte. Gezien de WCGSresultaten kan gesteld worden, dat de als A getypeerde mannen een vergrote kans lopen op het in de toekomst ontwikkelen van eer $\mathrm{CHz}$.

Met behulp van de ondexzoeksgegevens van de BUL blijkt het dus mogelijk om de proefpersonen als A of B te typeren. Wanneer de overeenstemming met de interview-typering hoog is, zou de BUL een mogelijkheid bleden om bij een epidemiologisch onderzoek naar risiko-faktoren bij het ontstaan van $\mathrm{CHz}$, de proefpersonen op een erenvoudige wijze in $A$ - en $B$-typen in te delen. Dit zou het afnemen van het interview kunnen vervangen, hetgeen tijd en kosten zou besparen.

Deze mogelijkheid werd aan het huldige materiaal nagegaan met behulp van een diskriminant analyse (Tatsuoka, 1.971), waarbij de skores van de 65 shell-mannen op de BuL-faktoren I, EII en IV werden ingevoera (Van Dij1, 1978). Met behulp van de hieruit berekende, ongestandaardiseerde aiskriminant funktie werd voox iedereproefpersoon in diskriminant skore (DS) bepaald, waarna een klassifikatie kon plaatsvinden door een dichotomisering in de skores aan te brengen in + skores en - skores. Het overeenstemmingspercentage (mate van repliceerbaarheid) met de interview-typering blijkt voor de Type A-mannen 80 w en voor de Type B-mannen 79\% te zijn (Van Dijl, 1978). Dit is een veelbelovend resultat, wanneer dit vergeleken wordt met de resultaten, die met de A/B-schal van de Amerikaanse versie van de JAS behald werden. Voor de Type A-mannen was het ovexeenstemingspercentage 65. voor de Type B-mannen 80:. Voor resultaten met de Nederlandse JAS-versie zie 12.5.1.

De resulaten met de BUL zijn echter wel geflatteerd, aangezien bij de berekeningen de groep van "niet te klassificeren" buiten beschouwing is gelaten.

Eerder (zie 11.5.6.) werd naar voren gebracht, dat de voor het elgen onderzoek gebruikte groepen hartinfarkt- 
patienten en astmatici op de BUL-faktoren weinig of geen verschillen vertonen. Voors bleken deze aignostische groepen in de meeste gevallon op de But-faktoren afwijkend van de "gezonden" te skoren en wel in dezelfde richting. Als deze gegevens in verband gebracht worden met de BuL-

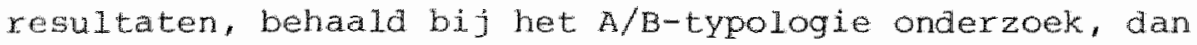
lijkt het zeer warschijnlijk at de volgens de BUL (maar ook de wolgens het gestandaardiseerde interview en ook de met de $A / B$-schaal van de JAS) gedetekteerde Type A-personen, een verhoogde kans hebben op het krijgen van ook andere ziekten dar CHz, in vergelijking tot Type B-personen. Een breed onderzoeksterrein komt daamee voor bewerking open te Iiggen. 


\section{SAMENVATTING EN SUGGESTIES VOOR VERDER ONDERZOEK.}

13.1. Betreffende het verrichte eigen onderzoek.

13.1.1. Doelstelling.

De doelstelling van het onderhavige onderzoek werd afgeleid uit de hypothese der psychosomatische Specificiteit, welke- aldus Groen e.a. (1965) - inhoudt "dat voor het ontstaan van een specifiek ziektebeeld drie factoren nocdzakelijk zijn: een bepaalde persoonlijkheidsstructuur, een bepaalde tussenmenselijke conflictsituatie en een bepaalde wijze van gedrag in zulk een situatie". Gezien het empirische karakter van het beoogde onderzoek en de aard van het onderzoeksinstrument werd uit deze algemene hypothese der Psychosomatische Specificiteit de volgende doelstelling afgeleid: het toetsen van de hypothese, dat personen met een specifiek ziektebeeld zich op bepaalde psychologische onderzoeksvariabelen onderscheiden van personen die niet aan dat specifieke ziektebeeld lijden. Van de veelomvattende hypothese der Psychosomatische Specificitelt werd derhalve alleen de relatie "persoonlijkheidsstructuur" en specifiek ziektebeeld aan een onderzoek onderworpen.

13.1.2. Het specifieke ziektebeeld.

Als specifiek ziektebeeld werd voor het beoogde onderzoek het hartinfarkt gekozen. Bovengenoemde algemene hypothese werd getoetst middels een vergelijking van de resultaten bij bepaalde onderzoeksvariabelen van mannelijke hartinfarktpatiënten (Hips) met die van:

(a) "gezonde" mannen,

(b) mannelijke astmatici en

(c) mannen met medische diagnoses anders dan hartinfarkt en astma bronchiale.

13.1.3. Het onderzoeksinstrument.

Als onderzoeksinstrument fungeerde de Beoordelen-van-Uitspraken-Lijst (BUL), die speciaal voor het hypothesen-toetsende onderzoek gekonstrueerd werd.

De inhoud van de items is gebaseerd op klinisch-psychologische persoonlijkheids- en gedragsbeschrijvingen van hartinfarktpatiënten (Hips) en astmatici. In een aantal gevallen bestaan de items uit opvallend vaak voorkomende verbale uitdrukkingen van deze patienten zelf. De beschrijvingen en uitdrukkingen werden getransformeerd tot uitspraken, met daarbij behorende 6 punts beoordelingsschalen. 
De achterliggende verwachting bij het genereren van deze items was, dat Hips - gezien bepalde klinisch-psychologische beschrijuingen en kaxaktexiseringen - op bepaalde items een andere wijze van beoordelen zouden vertonen dan in casu astmatici of "gezonden".

13.1.4. De onderzoeksvariabelen.

De BUL, bestaande uit 69 items, werd voorgelega aan ruim 1300 , volgens bepaalde kriteria "gezond" geachte mannen, in leeftija variexrende tussen 15 en 65 jaar.

Dit materiaal diende als basis voor een faktoranalyse, waarbij 6 untexpreteerbave faktoren naar voren kwamen. Op basis van de inhoud van de daarop relatief hoogladende items konden deze faktoren als volgt worden benoema:

(1) BUL-Faktor I (BF-I), die geacht wordt het persoonlijkheidskenmerk "agressiviteit" te meten.

(2) BUI-Faktor II (BF-II), die geacht wordt het persoonlijkheidskenmerk "depressiviteit" te meten.

(3) BUL-Faktor III (BF-III), die geacht wordt de waardering voor "aktiviteit en werken" te meten.

(4) BUL-Faktor IV (BF-IV), die geacht wordt "eerzucht en dominantie" te meten.

Aangezien de variabelen leeftija en schoolopleiding op deze BF-IV de hoogste ladingen vertonen, moet betwijfeld worden of deze BF-IV wel specifiek het geschatte persoonlijkheidskenmerk reflekteert. In verband hiermede werd van deze BF-IV in het onderhavige onderzoek geen gebrulk gemaakt.

(5) BUL-Faktor $V(B F-V)$, die geacht wordt het persoonlijkheidskenmerk "sociabiliteit" (gesteld zijn op omgang met mensen) te meten.

(6) BUI-Faktor VI (BF-VI), die geacht wordt het persooniljkheidskenmerk "beroepsverantwoordelijkheid" te meten.

13.1.5. Relevant geachte dimensies, gebaseerd op psychosomatische Iiteratuur.

U⿺t Ektoranalytische bewerking van de onderzoeksgegevens kwam naar voren, dat bepaalde klinisch-psychologische beschrijvingen en karakterisexingen middels de BuL-items statistisch als objektiave variabelen beschouwd konden worden.

In het volgende onderzoeksstadium werd de betreffende psychosomatische literatuur opnieuw doorgenomen en gerubriceerd volgens de via faktoranalytische weg gevonden "dimensies". In hoofdstuk 3 worden klinisch-psychologische en objektieve testpsychologische gegevens vermeld aangaande "agressiviteit" bij patienten met een coronaire hartziekte (cHz), in hoofdstuk 4 
aangaande "depressiviteit". In hoofdstuk 5 passeren gegevens betreffende de aktiviteitsgraad en werkinsteling bij CHZ-patienten de revue, in hoofdstuk 6 betreffende sociablilteit. Tot slot worden in hoofastuk 7 psychosomatische 11teratuurgegevens over het onderwerp "beroepsverantwoordelijkheid" bij CHz-patiënten behandella.

13.1.6. Hypathesen.

In hoofdstuk 8 worden vervolgens uit deze literatuurgegevens middels de BUL-faktoren toetsbaar geachte hypothesen afgeleid. Deze hypothesen worden daarbij gezien als "vexbijzonderingen" van de algemene hypothese der Psychosomatische specificiteit. voorts worden in hoofdstuk 8 enkele psychosomatische literatuurgegevens betreffende bepaalde persoonlijkheldskenmerken van astmatici vermeld en wel om de implikatie van de specificiteitshypothese te kunnen onderzoeken, dat personen iljdende aan de"specifieke' ziekte $A$ in hun pexsoonlijkiheidsstruktur verschillen vertonen in vergelijking tot personen lijdende aan de 'specifieke' ziekte $B$. Uit de literatuurgegevens over astmatici en Hips worden verschillen tussen beide groepen afgeleid en tot toetsbaar geachte hypothesen gevorm. "Tevers worden in hoofastuk 8 toetsbare hypothesen betreffende verschilLen tussen mannelijke Hips en "gezonde" mannen opgesteld. Om het onderzoeksterrein van de veel omvattende algemene specificiteitshypothese uit te breiden werd een kontrolegroep samengesteld bestaande uit in een kliniek voor interne geneeskunde opgenomen mannen met verschillende diaqnoses anders dan hartinfarkt en astma (de zogenoemde groep 'Internen'). Dit om de in de hypothese der psychosomatische specificiteit vervatte implikatie te onderzoeken, dat wanneer de "persoonlijkheidsstruktuur" van Hips "specifiek" is, dit dan ook moet blijken wanneer Hips op relevante varjabelen vergeleken worden met personen met andere medische diagnoses.

13.1.7. Onderzoeksbevindingen bij hartinfarktpatienten en gezonden. Bij 3 toetsingsonderzoekjngen blijken mannelijke Hips, in vergelijking tot gezonde manhen, overeenkomstig de hypothesen. statistisch signifikant anders te skoren:

op BF-I meer in de 'agressiviteit'-richting,

Op $B F-V$ meet in de 'sociablitteit'-richting en

op BF-VI meer in de 'beroepsverantwoordelikjkeld' $-x$ ichting. Bij 2 van de 3 toetsingsonderzoekingen blijken mannelijke Hips in vergelijking tot gezonde mannen, overeenkomstig de hypothese, statistisch signifikant anders te skoren: op BF-III meer in de 'aktiviteit en werken'-richting. 
Hiexbij moet opgemerkt worden, dat in het ene geval waarbij dit hiet gevoriden werd, de experimentele groep Hips op BF-III afwifkend skoort van de belde andere experimentele groepen Hips in de voox de te taetsen hypothese ongunstige richting. ook de kontrolegtoep "gezonden" skoort op BF-III afwijkend, in vergelijking tot de belde andere kontrolegroepen "gezonden" eveneens in de voox de te toetsen hypothese ongunstige richting. Gegeven het geheel van de desbetreffende onderzoeksbevindingen kan de betreffende hypothese desondanks als gesteund en houdbaar worden beschouwd.

Bij geen van de 3 toetsingsonderzoekingen wordt een statistisch signifikante steur gevonden voor de hypothese, dat mannelijke Hips, in vergelijking tot "gezonde" mannen, mér'depressiviteit' aangeven.

13.1.8. Onderzoeksbevindingen bij hartinfarktpatienten en astmatici. Bij 1 van de 2 toetsingsonderzoekingen blijken mannelijke Hips in vergelijking tot mannelijke astmatici, overeenkomstig de hypothese, statistisch signifikant anders te skoren: op BF-III mér in de 'aktiviteit en werken'-richting. In geen van de twee toetsingsonderzoekingen wordt statistisch signifikante steun gevonden voor de hypothesen, dat mannelijke Hips, in vergeljjking tot mannelijke astmatici een hogere positieve waardering vertonen bij het beoordelen van uitspraken respektievelijk betreffende:

(a) 'gesteld zijn op ongang met mensen' en

(b) 'beroepsverantwoordelijkheid'.

13.1.9. Onderzoeksbevindingen bij hartinfarktpatienten en patiénten lijdende aan verschillende ziektebeelden anders dan hartinfarkt en astma bronchiale.

Bij ển toetsingsonderzoek blijken Hips, in vergelijking tot patiênten met medische diagnoses anders dan hartinfarkt en astma, overeenkonstig de hypothesen, statistisch signifikant anders te skoren:

op BF-I meer in de "agressiviteit"-richting

op $B E^{\prime}-V$ meer in de "sociablliteit"-richting en

op BF"-VI meer in de "beroepsverantwoordelijkheid'-richting. Bij ë̉n toetsingsonderzoek wordt geen steun gevonden voor de hypothese dat mannelijke Hips, in vergelijking tot mannen met medische diagnoses anders dan hartinfarkt en astma, een hogere positieve wardering vertonen bij het beoordelen van uitspraken betreffende 'aktiviteit en werken'. Het gevonden verschil ligt zelfs in tegengestelde richting dan verwacht. Hilerbij moet opgemerkt worden, dat de experimentele groep Hips afwijkend skoort van de beide groepen Hips, in de voor 
de te toetsen hypothese ongunstige richting. Was voor de toetsing van de andere expeximentele groep van gehospltaliseerde Hips gebruik gemaakt, an was er wel een statistisch signifikante steun voor de betreffende hypothese gevonden. Dit gegeven rechtvaardigt op zijn must een tweede toetsing van de betreffende hypothese, alvorens had definitief te verwerpen. De overige resultaten zullen eext nog moeten worden gekruisvalideerd, alvorens de houdbarheid van de betreffende hypothesen aangenomen kan worden.

13.1.10. Konklusies met betrekking tot de onderzoeksbevindingen. (1) Bij herhaling werd enpirisch steun gevonden voor 4 van in total 5 hypothesen betreffende verschilden tussen mannelijke Hips en "gezonde" mannen (zie 13.1.7.). Hiemee wordt op indirekte wijze steun verleend an dat deel van de hypothese der. Psychosomatische specificiteit, warbij ovex verschillen in de "persoonlijkheidsstruktuur" wordt gesproken tussen personen met een 'specifiek' ziektebeeld en "gezonde" personen. De desbetreffende getoetste hypothesen zijn immexs op te vatten als "verbijzondexingen" van juist dat deel van de specificiteitshypothese. De skores van de groepen Hips en "gezonden" laten echter een grote mate van overlapping zien. Dit betekent, dat lang niet iedere hartinfarktpatient het veronderstelde kennerk vertoont. Dit pleit ervoor om in de psychosomatiek, wanneex het persoonljjkheidskenmerken betreft, beter over "typiciteit" dan over 'specificiteit' te spreken. Op grond van het retrospektieve karakter van het onderzoeksmateriaal kan echter njet uitgemakt worden, of de gevonden verschillen aan het infarkt vooraf gegaan zijn dan wel daarvan een gevolg zijn.

(2) Uit de onderzoeksbevindingen, vermeld in 13.1.9. kan gekonkludeerd worden, dat groepen mannelijke Hips en groepen mannelijke astmatici zeew weinig verschillen vertonen. Met deze resultaten wordt geen steun gevonden voor de implikatie wan de hypothese der Psychosomatische specificiteit, dat personeri 1ijdende aan ziekte A ("speciflek" ziektebeeld) en personen lijdende ari ziekte $B$ (ander 'speciflek' zlektebeeld) bepaalde verschillen in hun "persoonlijkheidsstruktuux" zouden vertonen. (3) Uit de resultaten, vermeld in 13.1.9. blijkt, dat voor Hips káxakteristiek geachte persoonlijkheidskenmerken duidelijker naar voren komen, wanneer hun skores op de gebruikte ondexzoeksvariabelen vergeleken worden met die van manren, 1.jjdende a an diverse specifieke ziektebeelden. Dit, gekombineerd met de resultaten uit 13.1.8. en het gegeven, dat de groepen bestaande uit astmapatiênten op bepaalde persoonlijkheidsvariabelen afwijkend skoren van de groepen bestaande ult "gezonden" en wel in dezelfde richting als de groepen Hips dat doen, doet vermoeden dat deze persoonlijkheidsvariabelen wel met het ene, maar niet met het andere specifieke ziektebeeld gekorreleerd zijn. 


\subsection{A/B-typologie en Jenkins Activity Survey (JAS).}

13.2.1. Definitie en onderzoeksbevindingen.

In hoofdstuk 12 wordt de A/B-typologie beschreven, zoals geinitieerd door de Amerikaanse cardiologen Friedman en Roserman en tevens de daarop gebaseerde psychologische vragenlijst, de Jenkins Activity Survey.

opvallend zijn de overeenkomsten van het zogenaamde Type Agedrag spatroon met voor CHz-patiënten beschreven kenmerken, zoals de verhoogde mate van agressiviteit (zie hoofdstuk 3), de verhoogde aktiviteitsgraad (zie hoofdstuk 5) en hun sterke eerzucht (zie 12.7.1.). De relevantie van het Type A-gedrag bij het zoeken naar risiko-faktoren voor CHz blijkt o.a. uit de Western Collaborative Group Study (WCGS). Bij het prevalantieonderzoek bleek onder Type A-mannen ruim 2 mall vaker een $\mathrm{CHZ}$ voor te komen dan onder Type B-mannen. Bij een follow-up onderzoek na gemiddeld $8 \frac{1}{2}$ jaar is de risikoratio van ruim 2 maal zo veel nog steeds van kracht. Het konstrukt van de $A / B-$ typologie heeft dus een zekere prediktieve validiteit t.a.v. het ontwikkelen van $\mathrm{CHZ}$. Bij een vergelijking van deze prediktieve validiteit met die van bepaalde bekende somatische risikofaktoren blijkt deze niet voor die van de somatische onder te doen.

Jenkins (1968) trachtte de A/B-typologie te objektiveren middels de konstruktie van een vragenlijst, de Jenkins Activity Survey (JAS). Deze is bedoeld 'for measuring the coronaryprone behavior pattern'. Met de zogeheten $A / B$-schal van deze JAs kon 68\% van de Type A- en $73 \%$ van de Type B-mannen als zodanig geidentificeerd worden. Faktoranalyses op de door de WCGS-mannen ingevulde JAS vragenlijsten leverden 3 onafhankelijke faktoren op, benoemd als: H(ard-driving), J(ob-involvement) en $s$ (peed and Impatience). Bij retrospektief onderzoek bleken de $A / B$-schaal en JAS-faktor $H$ een redelijke gelijktijdigheidsvaliditeit t.a.v. CHz te bezitten. Bij prospektief onderzoek bleek alleen de $A / B$-schaal valide. Als voorspeller op individueel nivo laat de $A / B$-schal van de JAS veel te wensen over. Later onderzoek wees uit, dat voor het ontwikkelen van een relevante schaal de diagnostische kategorie: CHz, te ruim is. Ook wat betreft de onderhavige persoonlijkheidskenmerken lijkt differentiatie aangewezen in: akuut infarkt, 'still' infarkt en angina pectoris, zodat ex ter prognostiek op zijn minst drie verschillende schalen gekonstrueerd zouden moeten worden (Jenkins e.a. 1978).

Door Appels (1979) werd de JAS voor Nederland bewerkt. Vooralsnog lijkt de Amerikaanse versie beter Type A-mannen te identificeren dan de Nederlandse, voor de Type B-mannen ligt 
dit voor beide versies ongeveer gelijk. De Nederlandse $A / B-$ schaal heeft enige relevantie op cardiovasculalr gebied. De JAS-Faktoren H(ard-driving) en J(ob-involvement) zijn herkenbaar in de BUL-Faktoren III (Aktiviteit en werken), IV (Eerzucht/Dominantie) en VI (Beroepsverantwoordelijkheid). Voor BUL-Faktor I (Agressiviteit) is daarentegen bij de JAs geen ekwivalent aanwijsbaar, evenmin als voor BUL-Faktor II (Depressiviteit) en BUL-Faktor V (Sociabiliteit). voor JASFaktor $S$ (peed and Impatience) is daarentegen bij de BUL niet zonder meer een ekwivalent te vinden.

13.2.2. BuL-resultaten bij Type A- en Type B-mannen. Gezien de grote mate van overeenkomst tussen klinische persoonlijkheids- en gedragsbeschrijvingen van cHz-patiënten en de kemmerken van het Type A-gedrag en de overeenkomsten tussen JAS en BUL, kan aangenomen worden, dat bepalde kenmerken van het Type A-gedragspatroon met de BUi meetbaar zijn.

Bij onderzoek bleken Type A-mannen, in vergelijking tot Type B mannen, op BF-I hoger in de 'agressiviteit' - richting te skoren, op BF-III hoger in de 'aktiviteit en werken'-richting en op BF-IV hoger in de "eerzucht en dominantie"-richting (zie 2.3.3. In verband met relatief hoge ladingen van leeftijd en opleidingsnivo op BF-IV. De Type A- en B-manmen zijn overigens van ongeveer dezelfde leeftija).

vanuit de $A / B$-typologie verwachte verschillen tussen Type $A-$ en B-mannen blijken dus met een objektieve methode, die los van deze typologie ontwikkeld werd, statistisch signifikant aantoonbaar. Met behulp van een diskriminant funktie kon van de Type A-mannen 80\% en van de Type B-mannen 79\% als zodanig geidentificeerd worden.

\subsection{Suggesties voor verder onderzoek}

13.3.1. Inleiding.

Het in ait proefschrift beschreven onderzoek toont aan, dat groepen hartinfarktpatiënten (Hups) en groepen astmatici op de gebruikte BuL-faktoren weirig of geen verschillen vertonen en in het algemeen ten opzichte van groepen "gezonden" in dezelfde richting liggende afwijkingen. Op grond hiervan kan verwacht worden, dat dit evenzeer voor de bij het A/B-typologie onderzoek gevonden diskriminantiefunktie van de BuL geldt. Met andere woorden: een relatief hoge skore op deze tussen Type $A$ - en Type B-mannen diskriminerende variabele (wijzend op het Type A-gedragspatroon) is niet alleen gekorreleexd met een verhoogde kans op een $\mathrm{CHz}$, maar zeer warschijniljk ook met een verhoogde kans op het kxijger van een andere psychosona- 
tische aandoenjng. Ditzelfde zal zeer warschijnlijk ook gelden voor de $A / B$ schal van zowel de Amerikaanse als de Nederlandse versie van de JAs en voor de via het gestandaardiseerde interview aangewezen Type A-personen. Dit betekent, dat er een breed onderzoekstercein voor verdere bewerking op basis van de huidige gegevens openligt, warbij dan niet alleen CHz maar ook andere zlektebeelden onderwerp voor onderzoek vormen. op twee aspekten van een dergelijk onderzoek naar risikofaktoren bij het ontstaan van bepaalde ziektebeelden zal hier nader ingegaan worden, te weten:

a. de onderzoeksopzet en

b. relevante psychologische onderzoeksvariabelen.

13.3.2. Preferenties ten aanzien van onderzoeksopzet.

Bij een onderzoek naax risikofaktoren voor het ontstaan van een $\mathrm{CHz}$ (of andere ziekte) verdient een prospektieve onderzoeksopzet de voorkeur. Dit geldt voor zowel een onderzoek naar biomedische als naar psychomedische risikofaktoren. zo vermelat Appels (1978), dat b.v. hoge bloedaruk (somatische risikofaktor) na een infarkt kan verdwijnen. De rol van hoge bloedaruk als risikofaktor bij het ontstaan van en CHz zou dan bij retrospektieve onderzoekingen vertekend raken. zo kunnen ook de resultaten bij psychologische onderzoeksvariabelen beinvloed zijn door het doorgemakkt hebben van een ziekte, met name de antwoorden gegeven op een psychologische wragenlijst. In dit verband kan een prospektief cardiovasculair ondexzoek genoemd worden van friedman e.a. (1974) warbij in de psychologische methode b. v . het item voorkont: "I work best under pressure of outside demands, deadilines eto." . Verwacht kan worden - gezien de $A / B$-typologie en beschrijvingon van Hips - dat toekonstige hartinfarktpatièt ten hieropo vaker het "ja"-antwoord geven dan personen die infarktvrij wullen blijven. Jit hun gegevens blijkt echter, dat van de personen die een hartinfarkt ontwikkelden nadat zij deze vraag beantwoord hadden, 18 het "ja'-antwoord gegeven had. Van de kontroles darentegen had 28 'het 'ja'-antwoord gegeven ( $p<.01)$. Alleen via een prospektieve onderzoeksopzet kon de werkelijke prediktieve validiteit van dit item voor het ontwikkelen van het hartinfarkt geëxploreerd worden. Ditzelfde zou kunnen gelden voor andexe somatische ziektebeeldem, indien die in een prospektief ondexzoek betrokken zouden worden. Een ander voordeel van een prospektieve onderzoeksopzet is het ondervangen van de faktor "selektief overlijaen". Hiermee wordt bedoeld, dat op deze wijze ook informatie gebruikt kan worden (b.V. antwoorden op testvragen) van personen die intussen dan de betreffende ziekte overleder. voor het hartin-

- Het betreft hier Gary D. Friedman en miet de initiator van de A/B-typologie Mayer Friedman. 
farkt b.V. is bekend, dat ongeveer 30 s onmiddellijk aan het infarkt overlijat. Bij een retrospektief onderaok van ket infarkt wordt alle informatie van deze 30 bij poorbat gemist. Een gekombineerd prospektief onderzoek naar psychologische èn somatische risikofaktoren zou de volgende voordelen bieden: a. Met betrekking tot de medische diagnosen. Gezien de bovinding at er voor de konstruktie van een relevante prediktievo psychologische testvariabele onderscheid genalkt moet worden tussen de diverse manifestaties van de CHZ (zie 13.2.1.) "is juist het stellen van de goede diagnose onontbeerlijk. b. Uit gegevens van Rosenman e.a. (1975), gebaseera op het WCGS follow-up onderzoek na $8 \mathrm{t}_{5}$ jaar, kan afgeleid worden, dat bij Type A-mannen van 39-49 jaar met een systolische hypertensie, de gemiddelde jaarlijkse CHz-incidentie 2,6 maal groter is dan bij de Type B-mannen van dezelfde leeftijd met eveneens een systolische hypertensie. voor diastolische hypertensie is deze ratio: 2,4 mal groter.

Dit wijst erop, dat een formule het meest valide zal zijn, wanneer daarbij een kombinatie van zowel somatische als psychologische variabelen gehanteerd wordt. voor een aantal andere somatische ziektebeelden liggen soortgelijke veronderstellingen voor de hand.

Een gekombineerde longitudinale medisch/psychologische onderzoeksopzet makt het mogelijk om bij het gedurende jaren volgen van de proefpersonen die personen te selekteren, die een bepaalde somatische ziekte ontwikkelen nadat zij onderzocht zijn. Personen met dezelfae ziekte kunnen dan tot een externe kriteriumgroep gerekend worden. De door deze personen ingevulde psychologische vragenlijst(en) kan (kunnen) dan als basis dienen voor het uitvoeren van een item-analyse, d.w.z. ex wordt dan nagegaan welke test-items tussen personen mèt en zonder die ziekte diskrimineren. Uit deze kan (kunnen) dan een variabele(n) gekonstrueerd worden met een prediktieve validiteit. Deze variabele kan dan opgevat worden als een psychologische risikofaktor. In voortgezet onderzoek zou dan nagegaan moeten worden, hoe hoog deze prediktieve validitelt is, het liefst in kombinatie met medisch/somatische risikofaktoren.

\subsubsection{Relevant geachte psychologische testvariabelen.}

13.3.3.1. Inleiding.

Bij prospektief onderzoek, zoals voorafgaand geschetst, doet zich de vraag voor welke psychologische onderzoeksvariabelen daarbij relevant geacht kunnen worden. Op grond van eigen onderzoeksresultaten en die van andere onderzoekers, dringen zich een aantal testpsychologische variabelen op, die opgevat 
kunner worden als het risikoprofiel wan de chz-patient. In welke mate zulk een profiel ook voor personen met een andere somatische ziekte gelat, wordt hier in het midden gelaten. Een psychologische test ten behoeve van prospektief CHz-onderzoek zou iterns moten bevatten die met dimensies gekorreleerd zijn, welke hieronder achtereenolgens opgesomd zulden worden.

\subsubsection{Agressiviteit/Hostiliteit.}

Uitgaande van de resultaten uit het BuL-onderzoek lijkt de dimensie 'Agxessiviteit' of 'Hostiliteit' veelbelovend voor een exploratief onderzoek naar psychologische risikofaktoren bij het antstaan van CHz (zie 13.1.7.). Aanwijzingen in dezelfde richting vonden klein en Parsons (1968), Theorell en Rahe (1972), $\operatorname{van}$ Diji en Nagelkerke (1978) (zie 3.2.5.), terwijl ex voorts aan herinnerd zij, dat "Hostility" een komponent is bij het gestandaardiseerde interview van de $A / B-$ typologie. Het gegeven uit de WCGS, dat het Type A-gedrag samengaat met een verhoogde kans op een $\mathrm{CHz}$, wijst eveneens op de relevantie van een "hostiliteits"-faktor.

Door van Doornen (1979) werd overigens met de BUL niet de relevantie van een "agressiviteits'-dimensie, zoals gemeten thet BF-I, gevonden. Bij dat orderzoek werden de BuL-Faktorskores gebruikt var 46 Hips en van mannen met een laagen wan mannen met een Hoog risiko, ten aanzien van het ontwikelen van een $\mathrm{CHZ}$.

13.3.3.3. Depressiviteit.

Hoewel in het eigen onderzoek geen aanwijzingen gevonden worden voor de relevantie van een 'depressiviteits'-dimensie, zoalis gemeten door BF-II (zie 13.1.7.), als psychologische risikofaktor bij cHz, zijn er toch een aantal gegevens die onderroek met behoud van deze dimensie toch de noeite ward bl.jven maken. Het betreft de resultaten van de retrospektileve onderzoekingen van Mordkoff en Rand (1968) met de MMPI en de Mood Scale van Clyde; van kleir en Parsons (1968), eveneens met de Mood scale van clyde; van Thiel e.a. (1973) met een gemodicicerde Depressie schaal van welsh en van Appels e.a. (1979 A) met de Mastrichtse Vragenlijst (zie 4.1.5.). Door Nass e.a. (1979) werd met de laatst genoemde vragenlijst, destijas Rotterdamse vragenlijst geheten, gevonden, dat deze op univariaat nivo van 14 relevant geachte schalen het beste diskrimineerde ( $p=01$ ) tussen een groep van 58 mannelijke Hips en een groep van 58 mannelijke kontrales, gematched voor social-economische status en leeftijd. Terecht wijzen deze auteurs overigens op de mogelijkheid, 
dat de verhoogde depressiviteitsskore van de Hips op aeze lijst (mede)-bepaala kan zijn doox het doorgemaakt hebben van het infarkt. In dit verband dient gewezen te worden op de negatieve resultaten bij de prospektive onderzow kingen van ostfeld e.a. (1964), Shekelle en ostfeld (1965), Lebovits (1967) en Brozek e.a. (1966) (zie 4.1.5.). Uit een aantal van deze onderzoekingen kont overigens naar voren, dat de 'depressiviteits'-dimensie wel relevantie lijkt te hebben voor de voorspelling van eem recidief van het infarkt.

ook bij van Doornen (1979, zie 13.3.3.2.) wordt een aanwijzing gevonden, dat een 'depressiviteits'-dimensie toch de aandacht veraient. De door hem gekonstateerde mate van vexhoogde depressiviteit kan onmogelijk bepaald zijn door het doorgemaakt hebben van een CHz, aangezien dit gevonden werd voor mannen met een Hoog-risiko nivo, zonder cHz. Dit pleit voor een verhoogde depressiviteit voorafgaand aan een $\mathrm{CHz}$. voorts vermeldt van Doornen (1979), dat bij een diskriminantanalyse BF-II: Depressiviteit, de belangrijkste diskriminerende variabele bleek tussen de Hoog-en Laag-risiko groepen. ook eigen onderzoek met Nagelkerke (1978) wijst op de relevantie van eer 'depressiviteits"-dimensie. Al met al lijkt het vooralsnog aan te bevelen om bij een epidemiologisch incidentie onderzoek naar psychologische risjkofaktoren een "depressiviteits"-dimensie in het onderzoeksprogramma op te nemen.

13.3.3.4. Aktiviteit/Werk/Eerzucht/Beroepsverantwoondelijkheid. Bij herhaling komen bij het onderzoek naar celevante psychologische variabelen bij CHz dimensies naar voren, die te maken hebben met verhoogde aktiviteit, eerzucht, beroepsverantwoordelijkheid en prestatiegerichtheid. Deze dimensies worden hier onder én hoofa ondergebracht, omat ze alle zeer nauw samenhangen met "werk" en "werksituatie". Hier worden de retrospektieve onderzoeksbevindingen van Wardwell e.a. (1968) en de prospektieve van BroZek e.a. (1966) in herinnering gebracht (zLe 5.1.5.).

ook het eigen retrospektieve onderzoek wijst op de relevantie van een dergelijke dimensie (zie 13.1.7.), evenals het BUI onderzoek bij de Type A- en Type B-mannen (zie 1.3.2.2.) en het recente eigen onderzoek met Nagelkerke (1978). De onderzoeksbevindingen van van Doornen (1979), Jenkins e.a. (1974) en van Nass e.a. (1979) duiden eveneens op de relevantie van een dimensie die betrekking heeft op verhoogde aktiviteit, eerzucht, beroepsverantwoordelijkheid en prestatiegerichtheid. 
13.3.3.5. Sociabiliteit.

In thet eigen onderzoek komt herhaldelijk naar voren, dat Hips op BF-V hoger skoren in de richting van 'gesteld-zijn op omgang met mensen" dan gezonden (zie 13.1.7.). Dit wist op de relevantie van een dergelijke dimensie voor het onderzoek bij chz (en wellicht ook bij andere ziektebeelden ?). steun hiervoor wordt ook gevonden in de onderzoeksresultaten van Siltanen e.a. (1975) met behulp van de Rorschach en van Miles e.a. (1954) met de 16 personality Factors Test wan Cattell (1957). Geen steun wordt daarvoor overigens gevonden door van der vallk (1960) met behulp van een vragenlijst; storment (1951) met de 13 Personality Factors Test van GuilFord en Martin (1943); Brozek e.a. (1966) met de Temperament Schedule van Thurstone (1950); Finn e.a. (1966), Lebovits e.a. (1967), Bruhn e.a. (1967), noch door van Doornen (1979) en van Dijl en Nagelkerke (1978). Afgezien van zijn mogelijke warde voox exploratief onderzoek maakt ait alles de relevantie van de dimensie "sociabiliteit", in vergelijking tot de eerder genoemde dimensies, twijfelachtig.

13.3.3.6. Neuroticisme.

In verband met de betekenis van een dimensie: neuroticisme, merkt van Doornen (1979) bij zijn hartinfarktonderzoek met behulp van de zelfbeoordelingsvragenlijst van Fey (zie 13.3.3.2.) op: "Hoewel Depressie en Neuroticisme als mogelijke elementen van de infarkt risikopersoonlijkheid door het A-patroon de laatste jaren wat naar de achtergrond zijn verdrongen, zijn dat ons inziens minstens zulke belangrijke aspecten van de risikopersoonlijkheid, waarbij met name Depressie hernieuwde belangstelling verdient". Daar staat overigens tegenover, dat bij een prospektief onderzoek door Lebovits e.a. (1967) met de neuroticisme schal van de MMPI geen verschil gevonden werd tussen toekomstige infarktpatienten en personen die tijdens het verloop van het onderzoek wxij van een infarkt bleven. De gegevens van het longutudinalle onderzoek door ostfeld e.a. (1964) en Bruhn e.a. (1969) zijn hiermee in overeenstemming (zie 4.1.5.). De relevantie van een neuroticisme dimensie voor een prospektief incidentie onderzoek naar $\mathrm{CHz}$ is derhalve twijfelachtig.

13.3.3.7. ongeduld en Tijasangst. ongeduld (speed and Impatience) is een faktor bij de JAS. ontstaan uit de ongeduld-komponent van het Type A-gedragspatroon. Ook van Doornen (1979) vond deze Eaktor bij faktoranalytisch onderzoek (zie 13.3.3.2.). 
Deze Ongedulds-dimensie heeft zeer warschijnlijk een sterke relatie met Tijdsangst langst dat de tija te snel voorbijgaat). Althans de onderzoeksresultaten van Nass e.a. (1979) wijzen in deze richting. Bij hun onderzoek maakten zij o.a. gebruik van de subschaal Tijasangst uit de Westerse Tijasattitude Schaal (WTAS) van Winnubst (1975). Op univariaat nivo werd met deze schaal een signifikante diskriminatie gevonden tussen hun groep Hips en hun groep van kontrolepersonen. De Tijasangst schal korreleerde bij de groep Hips .54 met de Nederlandse versie van de A/B schal. van de JAS en .53 bij de groep van kontrolepersonen. Dit wijst op een belangrijk verband en het opnemen van ilems ، betrekking hebbende op ongeduld en Tijasangst un een totale itempool lijkt dan ook veelbelovend bij een onderzoek naar psychologische variabelen bij cHz (en andere ziekten ?).

13:3.3.8. konklusie.

Betreffende onderzoeksopzet en relevant te achten psychologische onderzoeksvariabelen als risikofaktoren bij het ontstaan van coronaire hartziekten (en wellicht ook andere somatische ziektebeelden) zijn de volgende richtijjnen aan te geven:

a. Wat betreft de onderzoeksopzet heeft een prospektief epidemiologisch incidentieonderzoek de roorkeur. Dit geheel biedt de volgende voordelen:

1. Resultaten op zowel medische als psychologische onderzoeksvariabelen kunnen niet beinvloed zijn door de manifeste coronaire hartziekte.

2. De faktor "selektief overlijden" wordt ondervangen, hetgeen zeggen wil, dat ook onderzoeksgegevens van personen, die onmiddellijk aan hun ziekte overlijden ter beschikking staan.

3. Een samenwerking van psychologisch-met medisch deskundigen biedt de meeste garantie voor een juiste diagnosestelling. Voorts zou een prediktieve formule opgesteld kunnen worden, warin zowel medische als psychologlsche variabelen een plaats hebben.

b. Wat betreft relevant te achten psychologische variabelen dient een psychologisch onderzoeksinstrument in ieder geval items te bevatten die behoren tot de volgende dimensies:

- agressiviteit/hostiliteit;

- depressiviteit;

- aktiviteit/werken/eerzucht/beroepsverantwoordelijkheid/ prestatiegerichtheid.

Ten aanzien van de dimensies: Sociabiliteit en Neuroticisme 
is de relevantie, op basis van thans beschikbare onderzoeksgegevens, niet overtuigend te bepleiten. 
SUMMARY.

I. MY OWN RESEARCH PROJECT.

I.1. Purposes

The objective of this research has been derived from the hypothesis of psychosomatic specificity, which according bo croen et a1. (1965)-implies "that for the existerice of a specilic disease picture three factors are essential: a certain personality structure, a certain interpersonal conflict situation and a certain behavior pattern in such a situation". In view of the empirical character of the afore-mentioned research and the nature of the research instrument, the following objectives have been derived from thisgeneral hypothesis of psychosomatic specificity: The testing of the hypothesis, that persons with a specific disease pictu$r e$ distinguish themselves in certain psychological variables from persons not suffering from that specific syndrome. The hypothesis of psychosomatic specificity is so complex that only the part of "the personality structure" in relation to the pathogenesis of myocardial infarction has been examined.

1.2. The "specific" disease picture

The myacardial infarction was chosen as the "specific" disease picture for the concerned study. The above-mentioned general hypothesis has been tested by comparing the results of certain variables of male myocardial infarction patients (Mips) with those of:
a. "healthy" males,
b. male asthmatics and
c. males with medical diagnoses other than infarction and bronchial asthma.

\subsection{Research instrument}

For testing the Rating of statements List (R.S.L.; -Dutch: BUI- ) has been used, specially constructed for this research dealing with the testing of the hypotheses. The contents of the items has been based on clinicalpsychological personality and behavioral descriptions of myocardial infarction patients (Mips) and asthmatics. In a number of cases the items consist of verbal expressions frequently used by these patients themselves. The descriptions and expressions were formulated into statements with 
the associated 6 point rating scales.

The underlying expectation, while generating these items has been: that Mips - gathering from certain clinicalpsychological descriptions and characterizations - would show a different way of evaluating certain items than asthmatics or "healthy" males.

\section{I.4. Variables}

The R.S.L. Consisting of 69 items was presented to more than 1300 males considered "healthy" (according to certain criteria) with ages varying between 15 and 65 . This material served as a basis for a factor-analysis, showing 6 factors that could be interpreted. Based on the contents of the relative highloading items these factors could be mentioned as follows:

1. R.S.L. Factor I (R.S.I.-I), which is supposed to measure the personality characteristic "aggressiveness".

2. R.S.L.-Factor II (R.S.L.-II), which is supposed to measure the personality characteristic "depressiveness".

3. R.S.L.-Factor III (R.S.I.-III), which is supposed to measure the appreciation for "activity and work".

4. R.S.L.-Factor IV (R.S.L.-IV), supposing to measure "ambition and dominance".

Since the variables age and education show the highest loadings on this R.S.L.-IV, it is doubtful that this R.S.L.-IV specifically reflects the assumed personality characteristic. In this connection said R.S.L.-IV has not been used in this research.

5. R.S.L.-Factor V (R.S.I.-V), which is supposed to measure the personality characteristic "sociability" (relatedness to other people).

6. R.S.I.-Factor VI (R.S.I.-VI), which is supposed to measure the personality characteristic "job responstbility

I.5. Relevant dimensions, based on psychosomatic litexature

From a factor-analytical processing of the research data it emerged that certain clinical-psychological descriptions and chatacterizations could be statistically considered to be objective vaxiables by means of R.S.L.-items.

In the following stage of research the concerned psychosomatio literature was again reviewed and classified according to "dimensions" found through factor-analysis.

In chapter 3 the clinical-psychological and objective testpsychological data are mentioned concerning "aggressiveness" 
shown by patients suffering from coronary heart disease (CHD), in chapter 4 those concerning "depressiveness".

In chapter 5 data with regard to the degree of activity and work ethic, shown by CHD patients are reviewed and in chapter 6 data concerning sociability.

Finally psychosomatic literature data on the subject of "job responsibility" of CHD patients are advanced in chapter 7 .

I.6. Hypotheses

In chapter 8 the R.S.L. testable hypotheses are derived from the above-mentioned literature data.

These hypotheses are thereby viewed as "differentiations" from that part of the psychosomatic specificity hypothesis which deals with "personality structure".

Moreover, chapter $B$ also mentions some psychosomatic literature data concerning certain "characteristics" of asthmatics in order to be able to analyse the implication of the specificity hypothesis, that persons suffering from the "specific" disease A differ in their personality structure from persons suffering from the "specific" disease B. From literature data on asthmatics and Mips the differences between both groups are derived and formulated to testable hypotheses. Testable hypotheses with regard to differences between male Mips and "healthy" males are also mentioned in chapter 8.

To extend the field of research of the complex specificity hypothesis a control group was formed consisting of males hospitalized in a clinic for internal diseases, with various diagnoses other than myocardial infarction and asthma (the "Internal" group). This was done to investiate the. implication contained in the hypothesis of psychosomatic specificity , that should the "personality structure" of Mips be specific, this specificity should also become apparent wher Mips are to be compared, on relevant variables, with persons with different medical diagnoses (various "specific" disease pictures).

1.7. Research findings on comparing myocardial infarction patients with healthy males

In 3 tests male Mips score, in comparison with healthy males, in accordance with the hypotheses, significantly:

- higher in the "aggressiveness" direction on R.S.I.-I,

- higher in the "sociability" direction on R.S.I.-V, and

- higher in the "job responsibility" direction on R.S.L.-VI. 
In 2 of the 3 tests male Mips score, in comparison with healthy males, in accordance with the hypothesis:

- significantly higher in the "activity and work" direction on R.S.L.-III.

It should be noted here, that in the only case in which this was not found the experimental group of Mips scores differently on R.S.L.-III from the two other experimental groups of Mips in an unfavourable direction, as regards the hypothesis to be tested.

The control group "healthy males" scores differently too on R.S.L.-III, in comparison with the two other control groups of "healthy males", also in an unfavourable direction, as regards the hypothesis to be tested.

Given the entire results, the hypothesis in question can yet be considered to be supported and tenable.

In none of the 3 tests is a statistically significant support found for the hypothesis that male Mips show more "depressiveness", in comparison with "healthy" males.

1.8. Research findings comparing myocardial infarction patients with asthmatics

In 1 of the 2 tests male Mips score, in comparison with male asthmatics, in accordance with the hypothesis, significantly: - higher in the "activity and work" direction on R.S.L.-III. In neither of the two tests has statistically significant support been found for the hypotheses, that male Mips in comparison with male asthmatics, show a higher positive appreciation when rating statements concerning resp.

a. "relatedness to people" and

b. "job responsibility".

1.9. Research findings comparing myocardial infarction patients and patients suffering from various syndromes other than myocardial infarction and bronchial asthma

In one test Mips score, in comparison with patients with diagnoses other than myocardial infarction and asthma, In accordance with the hypotheses, significantly:

- higher in the "aggressiveness" direction on R.S.L.-I,

- higher in the "sociability" direction on R.S.L.-V and

- higher in the "job responsibility" direction on R.S.L. -VI.

In one test no support is found for the hypothesis that male Mips, in comparison with males with medical diagnoses other than myocardial infarction, show a higher positive appreciation when rating statements concerning "activity and work". 
The difference found lies even in the opposite direction from what has been expected. It should be noted here, that the experimental group of Mips scores differentiy from the two other groups of Mips in an unfavourable airection, as regards the hypothesis to be tested. If for testing the material of the other experimental group of hospitalized Mips showld have been used, then a statistically significant support for the hypothesis concerned was found. This evidence at least justifies a second test of the hypothesis in question, before absolutely rejecting $1 t$. whe other results will first have to be cross-validated before the acceptability of the hypotheses concerned can be adopted.

\section{I.10. General conclusions}

1. By repetition 4 of the total of 5 hypotheses concerning the differences between male Mips and "healthy" males have been empiricaldy supported (see I.7.). This supports indirectly that part of the hypothesis of psychosomatic specificity, dealing with differences in "personality structure" between persons with a "specific" disease picture and "healthy" pexsons. The cested hypotheses concerned can indeed be considered as "ditferentiations" of precisely that part of the specificity hypothesis.

Based on the retrospective character of the research material however, it cannot be determined whether the differences found preceded the myocardial infarction or were a result thereof. It should be emphasized that these differences are based on comparisons between groups. A strong overlap of the scores is found when scrutinizing the individual. R.S.L.-factor scores of the Mips and the "healthy" men. This means that a relatively large part of the Mips does not manifest the hypothesized personality traits. In this context it seems better to speak of "typicity" than of "specificity" with regard to certain personality characteristics of psychosomatic patients.

2. From the results as mentioned in 1.8 . it can be concluded that groups of male Mips and groups of male asthmatics haraly show any differences on the psychological variables used. With these results the implication of the hypothesis of psychosomatic specificity, that persons suffering from disease A ("specific" syndrome) and persons suffering from disease B (other "specific" synarome) should show certain differences in their "personality 
structure", is not supported.

3. From the results mentioned in 1.9 . It becomes clear that "personality traits" characteristic for Mips emerge more clearly when these patients are compared with males suffering from various "specific" syndromes.

This combined with the results as mentioned in 1.8 . makes it most probable that the same personality traits arr relatively highly correlated with various "specific" syndromes

I. A/B-TYPOLOGIE AND THE JENKINS ACTIVITY SURVEY (JAS)

11.1. Description and research findings.

In chapter 12 the $A / B$-typology, as developed by the American cardiologists Friedman and Rosenman and the psychological questionnaire based thereon: the Jenkins Activity Survey (JAS), are described.

The similarities of the so-called Type A behavior pattern with the described traits characteristic for CHD patients are remarkable; such as a higher degree of aggressiveness (see chapter 3), the increased degree of activity and work (see chapter 5) and their strong ambition (see 12.7.1.). The relevancy of the Type $A$ behavior pattern when searching for risk-factors for $C H D$ appears amongst other things from the Western Collaborative Group study (WCGS).

During the prevailing research it became clear that CHD occurred well over twice as much among Type A males than among Type $B$ males.

By a follow-up research after $8 \frac{1}{2}$ years the risk ratio of well over twice as much still exists. Thus, the construct of the $A / B$-typology has a certain predictive validity as regards the development of CHD. When comparing this predictive validity with that of certain known somatic risk factors, this predictive validity does not seem to be surpassed by those of the somatic factors.

Jenkins (1968) tried to objectify the A/B-typology by constructing a questionnaire: The Jenkins Activity Survey (JAS). This survey is meant "for measuring the coronary-prone behavior pattern". With the so-called A/B scale of this JAS $68 \%$ of the Type A males and 73\% of the Type B males could be identified as such. Factor-analyses of the JAS-questionnaires filled out by the WCGS males revealed 3 independent factors, namely: H(ard-driving), J(ob-involvement) and $S$ (peed and Impatience). In a retrospective research the $A / B$ scale and the JAS-factor $\boldsymbol{H}$ appeared to have a reasonable 
concurrent validity with regard to CHD. In a prospective research only the $A / B$ scale appeared valid. As a predictor on an individual level the $A / B$ scale of the JAs leaves much to be desired.

Later research showed that the diagnostic catagory CHD is too broad for developing a relevant scale; also as far as "personality traits" are concermed one should differentiate in: acute infarction, "silent" infarction and angina pectoris, so that at least, for predictive purposes, three different scales should have to be constructed (Jenkins et al. 1978). Appels (1979) adapted the JAS for the Netherlands. At the moment the American version seems to identify Type A males better than the Dutch version, as far as Type $B$ males are concerned both versions are about equal. The Dutch $A / B$ scale has some relevancy in the cardiovascular field. The JAS-Factors $H$ (ard-driving) and J (ob involvement) are recognizable in the R.S.L.-Factors III. (Activity and work), IV (Ambition/Domination) and VI (Job responsibility).

On the other hand no equivalent for the R.S.L. - Factor I (Aggressiveness) can be assigned in the JAs, neither for the R.S.L.-Factor II (Depressiveness) nor for the R.S.L.Factor V (Sociability). However, for the JAS-Factor S peed and Impatience) it is not easy to find an equivalent in the R.S.I..

II.2. R.S.I.-results with Type A and Type B males

Judging from the considerable degree of similarity between the clinical descriptions of the personality and the behavior of CHD patients and the characteristics of the Type $A$ behavior and the similarities between the JAS and the R.S.I. it may be assumed, that certain characteristics of Type A behavior pattern can be measured by means of the R.S.I... During research "Iype A males scored much higher on R.S.I.-I in the "aggressiveness" direction, in comparison with Type B males; on R.S.L.-III they scored higher in the "activity and work" direction and on R.S.L.-IV higher in the "ambition and domination" direction.

Certain differences expected from the A/B-typology between Type $A$ and Type $B$ males appear to be significantly statistically demonstratable by means of an objective methor developed apart from said typology.

With the aid of a discriminant function $80 \%$ of the Type $A$ males and $79 \%$ of the Type $B$ males could be identified as such. 
III.1. Introduction

The research described in this thesis shows how groups of nyocardial infarction patients and groups of asthmatics, hardly manifested any differences on the psychological. variables used. Moreover, when compared with healthy people an identical scoring pattern is found in most cases. on these grounds it is to be expected that this applies equally as well to the discriminant function of the R.S.I., found during the $A / B-t y p o l o g y$ study. In other words: a relatively high score on this variable discriminating between Type $A$ and Type $B$ males (pointing at the Type $A$ behavior pattexn) is not only correlated with an increased chance on CHD, but probably also with an increased chance to be seizea with another (psycho) somatic illness.

It is very likely that the same also applies to the $A / B$ scale of the American as well as the Dutch version of the JAS and for the Type A people, selected by means of the standardized interview. This implies that there is a wide field of research open for Eurther work, based on the present data, in the course of which not only CHD's but also other syndromes can be subject to research. Two aspects of such a research of the risk factors by the occurrence of certain syndromes are hereby elaborated, name ly:

a. the research design and

b. the relevant psychological variables.

III.2. Preferences with regard to the research design When studying the risk factors causing CHD (or another disease) the prospective research design is to be preferred. mis applies to studying biomedical as well as psychomedical risk factors.

Appels (1978) e.g. mentions that high blood-pressure (somatic risk factor) can disappear after an infarction. The role of high blood-pressure as a risk factor when a CHD occurs would then give a distorted picture in a retrospective study. In this way the results of the psychological variables can have been influenced by having lived through a disease, as evidenced by the answers given to the psychological questionnaire. In this connection a prospective cardiovascular study of Friedman et al. (1974) can be mentioned, in which in the

* Gary D. Friedman is referred to in this case and not the originator of the $A / B-t y p o l o g y$ Mayer Friedman. 
psychological method $e . g$. the item: "I woxk better undex pressure of outside demands, deadlines etc." occurs. It can be expected - that in view of the A/B-typology and the descriptions of Mips - that prospective Mips will answer with "yes" to this more often than persons who will stay free of an infarction. From their data however, it becomes clear that of the persons, who developed a myocardial infarction after they had answered this question, 18: had given the answer "yes".

of the controls, on the other hand, 28 had given the answer "yes" (p C.01). Only via a prospective design the real predictive validity of this item with regard to developing myocardial infarction could be found out. The same could be applied to other somatic syndromes, if these should be brought into a prospective study. Another advantage of a prospective research design is to obviate the factor "selective dying". This means, that in this way information can also be used (e.g. answers on test questions) concerning patients, who in the meantime have died of the disease in question.

of myocardial infarction e.g." it is known that about $30 \%$ immediately die of the infarction. In a retrospective design all information of these $30 \%$ is lost beforehand. A combined medical/psychological prospective study could offer the following advantages:

a. with regard to medical diagnoses; the correct diagnosing is indispensable, in view of the findings, that for the construction of a relevant predictive psychological test variable a distinction should be made between the various manifestations of CHD (see II.1).

b. from data published by Rosenman et a1. (1975), based on the WCGS follow-up study after 8 years, jt can be deducted, that with Type A males between 39 and 49 years of age with systolic hypertension, the average yearly incidence of CHD is 2,6 times larger than with males of rype $B$ of the same group also having systolic hypertension. For diastolic hypertension this ratio 152,4 times greater.

This indicates, that a predictive formula will be most valia, when an combiriation of somatic as well as psychological. variables is used. For a number of other somatic syndromes such suppositions appear to be obvious.

A longitudinal medical/psychological design enables us, when following the subjects for years, to select those persons developing a certain somatic disease, after they have been examined. 
Persons with the same disease can ther be considered to belong to an external criterion-group. The psychological questionmare(s) Ellled out by these persons can serve as a basis to carry out an item-analysis, which means finding out which test-items discriminate between persons with or without that disease. On this basis (a) variable(s) can be constructed with a predictive validity. This variable can then be looked upon as a psychological risk factor. In a continued study it should have to be found out, how high this predictive validity is, preferably in combination with medical/somatic risk factors.

III.3. Psychological variables considered relevant

II. 3.1. Introduction.

In a prospective study, as described above, the question arises which psychological test variables can, in this case, be considered relevant. Based on results from our own research and those of other researchers, a number of testpsychological variables arise, which can be considered as the risk profile of the CHD-patient.

To what degree such a profile also applies to persons with another somatic disease, is not dealt with here.

A psychological test carried out for prospective CHD-study would contain items correlated with various dimensions, which will be summed up successively below.

\section{3.2. Aggressiveness/Hostility}

Starting from the results of the R.S.I. -research the dimension "Aggressiveness" or "Hostility" appears very promising for an explorative study of the psychological risk factors In the occurrence of CHD (see I.7.).

Indications in the same direction were found by klein and Paxsons (1968). Theorel1 and Rahe (1972), Van Dijl and Nagelkexke (1978) (see 3.2.5.), and it should also be remembered, that "Hostility" is a component of the standardized interview of the $A / B-t y p o l a g y$. Evidence from the WCGS, that the Type A behavior goes together with an increased chance of CHD, shows that a "hostility" factor is relevant.

As a matter of fact Van Doornen (1979) did not find with the R.S.L., the relevancy of an "aggressiveness" dimension, as was found in the R.S.L. - I.

During that study R.S.L.-factor scores of 46 Mips and of males with a so-called Low risk and of males with a socalled High risk (as regards the development of CHD) were 
used.

III. 3. 3. Depressiveness.

Although in my own research there was no indication found for the relevancy of a "depressiveness"-dimension, as measured by R.S.L.-II (see I.7.) as a psychological risk factor with CHD, there is still an amount of data, that continues to make a study, retaining this dimension, worth while. This would involve the results of the retrospective studies of Mordkoff and Rand (1968) with the MMPI (Minnesota Multiphasic Personality Inventory) and the Mood Scale of Clyde; and of Klein and Parsons (1968) also with the Mood Scale of Clyde; and of Thiel et al. (1973) with a modified Depression Scale of Welsh and Appels et al. (1979A) with the "Maastricht Questionnaire" (see 4.1.5.). By means of the last mentioned questionnaire, formerly called the "Rotterdam Questionnaire" "Nass et al. (1979) found that out of 14 scales considered relevant, said list discriminated best on univariate level $(\mathrm{p}=.01)$, between a group of 58 male Mips and a group of 58 male controls matched for socio-economic status and age. Quite righty the authors point at the possibility, that the increased depressiveness score of the Mips on this list can (also) be determined by having lived through an infarction. In this connection we should point out the negative results of the prospectlve studies of Ostfeld et al.(1964), shekelle and ostfeld (1965), Lebovits (1967) and Brozek et al. (1966). From a number of these studies it emerges that the "depressiveness"-dimension seems to be relevant when predicting a reinfarction. Van Doornen (1979, see III.3.2.) also indicates that a "depressiveness"-dimension stili deserves our attention. The degree of increased depressiveness as established by him cannot possibly be determined by having ilved through a CHD, as this was found for males with a High risk level, without having CHD. This probably points to an increased depressiveness preceding CHD. Van Doonnen (1979) also mentions that in a discriminant analysis the R.S.I.-Factor IIdepressiveness appeared to be the most important discriminant variable between the High and Low risk groups.

Our own studies (1978) also show the relevancy of a "depressiveness"-dimension. Concluding for the present it seems advisable, when carrying out an epidemiological incidence study of the psychological risk Factors to include a "depressiveness"-dimension in the study-program. 
III.3.4. Activity/Work/Arwition/Job responsibility.

When searching for relevant testpsychological variables with CHD, dimengions cone repeatedly forward that are connected with "beling active", ambition, work, job responsi. bility and performance drive. These dimensions are brought together here under one heading, because they are all close ly connected with "work" and "work climate".

Here we remind you of the retrospective research resubts of Wardwe11 et a1. (1968) and the prospective ones of Brozek et a.l. (1966) (see 5.1.5.).

Also my own retrospective study shows the relevancy of such a dimension (see I.7.), as well as the R.S.L.-research with Type $A$ and Type $B$ males (see II.2.) and the recent study of Van Dijl and Nagelkerke (1978).

Findings published by Van Doornen (1979), Jenkins et al. (1974), and of Nass et al. (1979) also point to the relevan$c y$ in this matter of a dimension referring to "increased activity", ambition, job responsibility and performance drive.

III. 3.5. Sociability.

In my own study the fact that Mips score higher than health males, on R.S.I. V., in the direction "relatedness to peopl is regularly shown (see $I .7$. ). This points to the relevancy of such a dimension when studying CHD (and perhaps also whe studying other syndromes?). This idea is also supported by the research results of siltanen et al. (1975) with the aid of the Rorschach test and of Miles et al. (1954) with the 16 Personality Factors Test of Catte11 (1957).

No support is found by Van der valk (1960) with the aid of a questionnaire; by storment (1951) with the 13 personality Factors Test of Guilford and Martin (1943); by Brozek et al (1966) with the Temperament Schedule of Thurstone (1950); by Finn et al. (1966); Lebovits et al. (1967); Bruhn et al. (1967) nor by Van Doornen (1979) and Van Dijl and Nagelkerk $(1978)$

Besides its posible value for explorative study, all this renders the relevancy in this case of the dimension "sociablity", in compaxison with the dimensions mentioned before doubteui.

III.3.6. Neuroticism.

In connection with the meaning of a dimension: neuroticism, Van Doornen (1.979) remarks, in his myocardial infarction 
study with the aid of the "Self Evaluation questionnaire" of Fey: "Although Depression and Neuroticism as possible elements of the myocardial infarction risk personality have been somewhat pushed to the background by the A-pattern, duxing the last few years, we think they are just as important aspects of the risk personality, whereby especialiy the element Depression deserves a renewed interest". Set off against this is the fact that in a prospective study by Lebovits et al. (1967) with the neuroticism scale of the MMPI no difference was found between future infarction during the course of the study. The data of the longitudinal research by ostefeld et al.(1964) and Bruhn et al. (1969) are in agreement with this (see 4.1 .5 .). The relevancy of a neuroticism dimension for a prospective incidence study on CHD is therefore also doubtful.

III.3.7. Impatience and Time Anxiety.

Impatience (Speed and Impatience) is a factor in the JAs, having arisen from the Impatience-component of the Type A behavior pattern. Van Doornen (1979) also found this factor in factoranalytical research (see III.3.2.). This Impatience dimension has very likely a strong relation with Time Anxiety (a fear that time passes too rapidly).

At least the test results of Nass et al. (1979) point in this direction. In their study. they used amongst other things the Subscale Time Anxiety from the Western Time Attitude scale (WTAS) of Winnubst (1975). On univariate level a significant discrimination between their group of Mips and their group of control-persons was found with the aid of this scale. For the group of Mips the Time Anxiety-scale correlated 0.54 with the Dutch version of the $A / B$ scale of the JAS; and 0.53 for the group of controls. This points to an important relation between these dimensions; the inclusion of items. relating to Impatience and rime Anxiety in a total itempool also seems most promising when studying the psychological variables of CHD (and other diseases?).

III.3.8. Conclusion.

Summarizing, the following guidelines can be given concerning the research design and the testpsychological variables thought relevant as risk factors associated with coronary heart diseases (and perhaps other somatic syndromes):

a. Wth regard to the research design an epidemiological prospective incidence study is preferred. AIl this offers the following advantages: 
1. Results on medical as well as psychological variables cannot be influenced by the manifest coronary heart disease or other possible diseases.

2. The factor "selective dying" is obviated, which means that of persons immediately dying from their disease data are also available.

3. A co-operation in the medical diciplines offers the best guarantee towards finding the correct diagnosis. furthermore a predictive formula could be constructed in which medical as well as psychological variables will have a place.

b. with regard to psychological variables thought relevant a psychological test-instrument should certainly contain items belonging to the following dimensions:

- Aggressiveness/Hostility,

- Depressiveness,

- Activity/Work/Ambition/Job responsibility/Performance arive,

- Impatience and Time Anxienty.

Based on data available at the moment, the relevancy of the dimensions Sociability and Neuroticism cannot be convincingIy justified.

Translated by Mrs.M.M.Meijers-Butzelaar. 
BII JLAGE 1 .

Enkele voorbeelden van BUL-items.

Grapjes maken doe ik:

nooit: -- :---:---1---:---:---: heel vaak.

Als ik tijdens mijn werk gestoord word, vind ik dat:

niet hinderlijk: ---:---:---|--:---:--- heel hinderlijk.

Koffie drinken vind ik:

heel lekker: ---:--1:-- |---:----- : helemal niet lekker.

Ongelijk bekennen kan ik:

heel moeilijk: -.-: - -

Als ik samen met andere mensen ben voel ik mij:

erg onzeker: ---:---:---|---:---:---: helemaal niet onzeker.

Als iemand iets voor mij gedaan heeft voel ik mij:

erg bezwaard: ---:--:--1---:----- : helemaal niet bezwaard.

Ik voel mij:

nooit somber: ---:---:-- |---:---:---: vaak somber.

Ik ben:

niet slordig: ---:---:---|---:---:---: erg slordig. 
BIULAGE 2 .

Met dank an de werkneners van de volgende bedrijven en instelingen, die meegewerkt hebben bij de samensteling van de "gezonde" Basisgroep:

Douwe Egberts Koninklijke Tabaksfabriek, Koflie Branderijer, Theehandel M.V., Joure.

Provinciale Planologisohe Dienst van Noord-Holland, Overveen. Prowinciale Electxiciteits Matechappij van Noord-Holland, Bloemendal.

Philips Duphar, Weesp.

Staatsbedrijf ader Posterijen, Telegrafie en Telefonie (PTT), Ansterdarn.

J.C. Boldoot N.V., Koninklijke Eau de Cologne Fabriek, Ansterdam. Weljers Industriem Handelsonderneming. Amsterdam.

Uitgeverij De Bezige Bij G.A., Amstexdam.

Gemeenschappe]ijk Administratiekantoor (GAK), Amsterdam.

Ford Automobiel Fabriek, N.V., Amsterdam.

Nederlandse Dok-en Scheepsbouw Maatschappij (NDSM), Amsterdam. IBM Nederland, N.V., Amsterdam.

Rijks Postspaarbank, Amsterdam. 
Uittreksel van een verslag van R. Potharst (1973), voormalig medewerker van het Mathematisch Centrum te Amsterdam. Het betreft de resultaten van een faktor-analyse op het BUt-materiaal van de 'gezonde" mannen uit de Basisgroep. Het verslag is getiteld:

Een factor-analyse in verband met een onderzoek naar de samenhang tussen haxtinfarct en werkdrang.

Het waarnemingsmateriaal bestaat uit de scores van 1336 gezonde proefpersonen op 71 variabelen. Variabele 1 is de leeftija van de desbetreffende proefpersoon in jaren, variabele 2 het opleidingsniveau (er zijn 3 opleidingsniveau"s, genumerd van $1 \mathrm{t} / \mathrm{m} 3$ ) en de overige 69 variabelen worden gevorma door de antwoorden op 69 aan de proefpersonen voorgelegde items uit een psychologische test, bekend onder de naam 'Beoordelen-van-Uitspraken-Lijst' (BUL). Voor elk van deze items bestonden 6 geordende antwoordmogelijkheden, genummerd van $1 \mathrm{t} / \mathrm{m} 6$.

Bij enkele (zeer weinig) proefpersonen ontbraken de scores op sommige van de 69 items; hier werd telkens de waarde $3 \frac{1}{2}$ ingevuld. De gegevens over leeftijd en opleiding waren compleet.

Allereerst zijn alle 2485 productmomentcorrelatie-coefficiënten tussen de 71 variabelen berekend. De in absolute waarde grootste van deze correlaties was 0,56 . Verder waren ex nog drie groter dan 0,50 en slechts acht tussen de 0,35 en 0,50. Verreweg het grootste deel der correlaties was in absolute waarde kleiner dan 0,30. Hoewel door het bijzonder grote aantal proefpersonen de nulhypothese van onathankelijkheid der variabelen zeker verworpen zou worden, en ex dus samenhang tussen de variabelen aantoonbaar is, is deze samenhang niet erg sterk te noemen. Dit wordt bevestigd door de multipele correlaties tussen elke variabele en alle andere, waarvan de kwadraten vrijwel. allemal beneden de 0,40 blijven: slechts acht van de 71 zijn groter dan 0,40 , de grootste is 0,47 . Zoals bekend kan het kwadraat van een multipele correlatie-coëfficiënt tussen eer variabele en een stel andere geinterpreteexd worden als dat deel van de varjantie van die ene variabele, dat verklaard wordt door de anderen. on de structur van de samenhang tussen de 71 variabelen verder te onderzoeken, is vervolgens op bovengenoemde correlatie-matrix een Factor-analyse volgens de methode van Jøxeskog (1963) uitgevoerd. Hierbij doet zich eerst het probleem voor van het bepalen van het aantal factoren. A priori was hierover niets bekend. ook het verloop van de eigenwaarden van $S$ (zie Joreskog $p$. 38 ) geeft geen aanwijzingen ontrent het te kiezen aantal factoren: de 12 grootste eigenwarden vertonen het beeld van een vloeiende curve zonder duidelijke knik. zie tabel 1 voor de eigenwararden. 


\begin{tabular}{|l|l||l|l|}
\hline 1 & 10,0 & 7 & 2,2 \\
2 & 6,6 & 8 & 2,0 \\
3 & 4,6 & 9 & 1,9 \\
4 & 3,6 & 10 & 1,9 \\
5 & 2,7 & 11 & 1,9 \\
6 & 2,3 & 12 & 1,8 \\
\hline
\end{tabular}

Tabe1 1. De twaalf grootste eigenwaarden van $S$

Dat we uiteindelijk gestopt zijn bij 8 factoren kan worden beschouwd als een compromis tussen de volgende argumenten:

(I) de t-waarde, die ongeveer 1 dient te zijn (zie Joreskog p. 38), is bij 8 factoren 1,024; dit pleit niet voor het opnemen van meer Factoren; bij 5 factoren is $t$ reeds 1,074 , zodat we wat $t$ betreft hadden kunnen volstaan met minder factoren.

(II) Het percentage verklaarde variantie is bij 8 factoren 24,82, niet hoog dus en in overeensteming met de verwachting wegens de over het algemeer lage correlaties tussen de variabelen. Bij 6 factoren is het percentage verklaarde variantie echter reeds 22,29 , zodat het toevoegen van de twee laatste factoren nog slechts een verbetering van $2 \mathrm{~L}_{2}$ opleverde. Ook bij het toevoegen van nog meer factoren mogen we geen reële verbetering van het percentage verklaarde variantie vexwachten.

(III) Vo6r het opnemen van meer factoren pleit echter het feit, dat bij 8 factoren sommige restcorrelaties nog geenszins te verwaarlozen zijn. Er zijn er verscheidene in absolute waarde boven de 0,10, de hoogste is zelfs 0,15 ; het merendeel is echter niet onrustbarend. (IV) De door Jøreskog (p. 109) voorgestelde procedure voor het toetsen van de hypothese dat $k$ factoren ( $b i j$ ons $k=8$ ) voldoende $z i j n$, tegen het alternatief dat er meer factoren opgenomen dienen te worden leidt in ons geval tot verwerping van de nulhypothese dat 8 voldoende zou zijn: $u_{8}=4670$ met 2015 vrijheidsgraden.

(v) Een praktisch bezwaar wan het toevoegen van nog meer factoren is dat de nieuwe factoren warschijnlijk oninterpreteerbaar zouden zijn wegens te lage ladingen.

Samenxattende kunnen we zeggen dat, hoewel, met het oog op (III) en (IV), de zaak waarschijnlijk gecompliceerder ligt dan bij een factormodel met 8 factoren, het niet onredelijk lijkt om zo'n model als eerste benadering aan te nemen.

De factor-ladingen boven de 0,35 in absolute waarde van de (met varimax) geroteerde 8 orthogonale factoren staan vermeld in tabel 2.

Er zijn in totaal 31 variabelen, die op geen der factoren hoger dan 0,35 laden. Al deze variabelen hebben een multipele correlatie-coëfficiënt kleinex dan 0,35 en slechts drie groter dan 0,25, zodat deze 


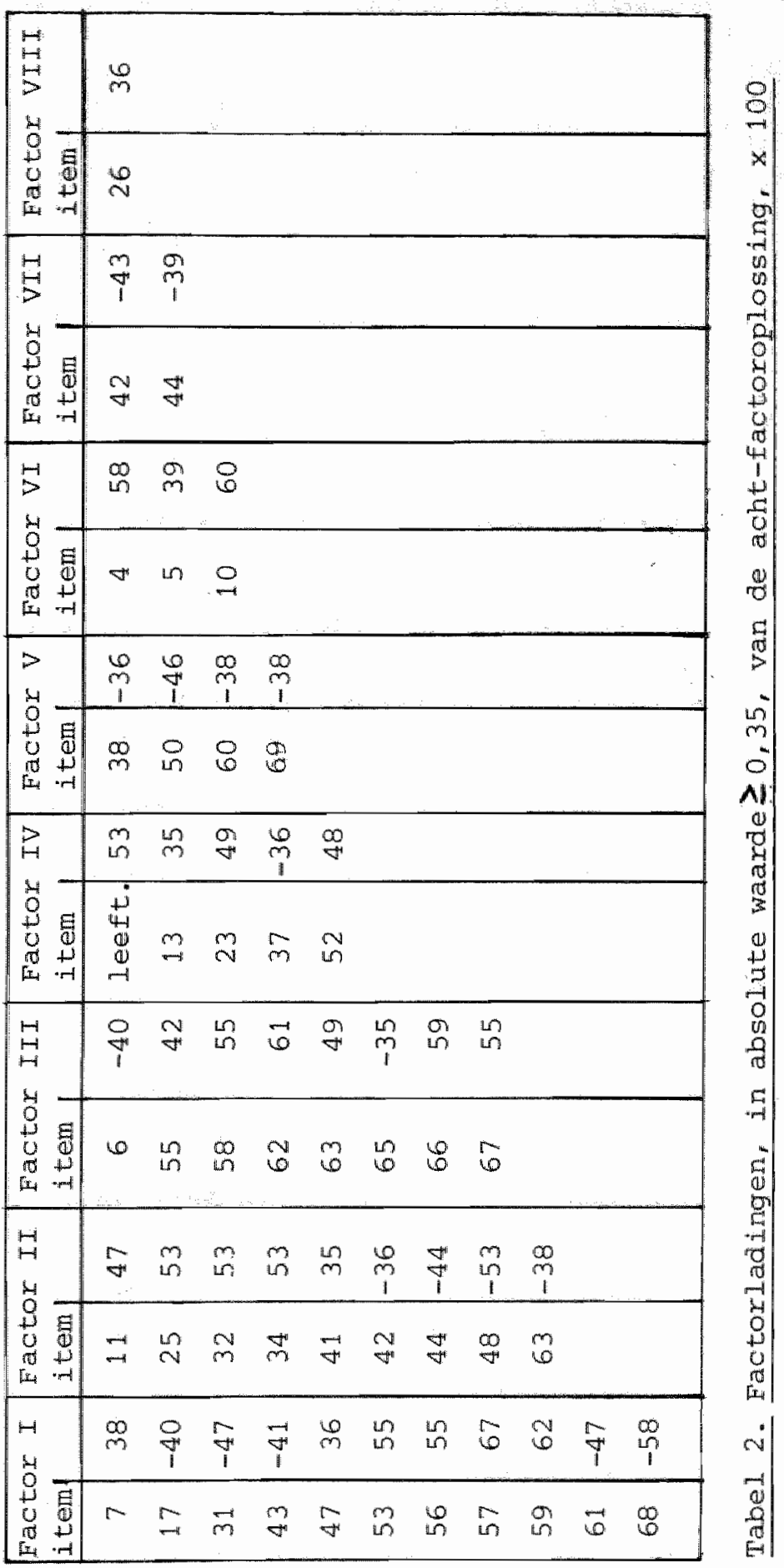


variabelen inderdaad weinig samenhangen met de rest.

Wat betreft de betroumbarheld van de factorladingen kan het volgende gezegd worden. Voox de ladingen van de ongeroteerde factoren zijn (volgens Joreskog, p. 57) grove schattingen berekend van de standaardafwifkingen van deze ladingen. Behalve bij de factoren 6 en 7 zijn al deze schattingen van de grootte-orde 0,01 tot 0,10 , zodat de ladingen warschijnljjk redelijk nauwkeurig geschat zijn. Dat de standaardafwljingen wan de factorladingen wan de factoren 6 en 7 hoger liggen (tussen zeg 0,10 en 0,25 ) is hoogstwaarschijnlijk te wijten aan het gexinge verschil tussen de $6^{e}$ en de $7^{e}$ eigenwararde van $S^{*}$. Dit hoeft ons niet te verontrusten, daar dit bij rotatie weer rechtgetrokken wordt (Jøreskog, p. 100).

De matrix van factorscore-coefficiénten is berekend volgens de methode van Anderson en Rubin (J力reskog, p. 41). Voor een willekeuxig proefpersoon, die de 71 vragen beantwoord heeft, kunnen we nu zijn (geschatte) factorscores op de 8 geëxtraheerde factoren berekenen doox vermenigvuldiging van zijn ruwe scores met de factorscore-coefficientenmatrix.

Theoretisch zouden de correlaties tussen de factorscores van elk paar Eactoren, bexekend over de groep proefpersonen waarvoor de factoranalyse is uitgevoerd, exact o moeten zijn. Ter controle van de invloed van afrondingen hebben we de correlaties tussen de factorscores van de eerste zes factoren berekend. De uitslag is weergegeven in de volgende tabel:

\begin{tabular}{l|rrrrr}
2 & 0,003 & & & & \\
4 & 0,000 & 0,000 & & & \\
5 & $-0,001$ & 0,001 & 0,000 & & \\
$-0,006$ & 0,012 & $-0,001$ & $-0,003$ & \\
0,005 & $-0,010$ & 0,001 & 0,003 & 0,022 \\
\hline 1 & 2 & 3 & 4 & 5
\end{tabular}

Tabe1. 3. Correlaties tussen de factorscores van de eerste zes factoren.

Deze afwijkingen van nul kunnen redelijkerwijs wel worden toegeschreven aan afrondingsfouten.

Bij het werk aan dit onderzoek zijn ook H. Elffers, G.J.F.P. Hanewald en J. Rijvordt betrokken geweest.

Iiteratuur

K.G. Joreskog, "Statistical Estimation in Factor Analysis". Stockholm, 1963 . 


\section{LITERATUUR.}

Alexander, F. en French, F.M. (1948): Studies in Psychosomatic Medicine. Ronald Press Comp., New York.

Alexander, F. (1952): Psychosomatic Medicine. Its principles and applications. George Allen and Unwin, London.

Alexander, F. en Szasz, Th.S. (1952): The psychosomatic approach in medicine. In: F. Alexander en H. Ross: Dynamic psychiatry. University of Chicago Press, Chicago.

Alexander, F., French, F.M. en Pollock, G.H. (1968): Psychosomatic specificity, vol. I. Experimental study and results. University of Chicago Press, Chicago.

Appels, A., Duiverman, R., Hey, H., Oudenaarden, W. van en Segeren, T. (1971): Aspecten van het A-type. Een onderzoek naar betekenis en bruikbaarheid van de JAS en de Voice Analysis Test in een nederlandse situatie. Med. Faculteit, Rotterdam, afd. Pxev. en Soc. Psychiatrie.

Appels, A. (1972): Het hartinfarct een cultuurziekte? Ned. T. V. Soc. Geneesk., 50, 446-448.

Appels, A. (1972A): Het hartinfarct als cultuurziekte. Ned. T. V. Psychol., 27, 553-565.

Appels, A. (1978): Een overzicht van het onderzoejk naar de rol van psychosociale factoren in het ontstaan van het hartinfarct. (Belgisch) T. V. Geneesk., 18, 1153-1189.

Appels, A. (1979): Bibliografie van psychosociale studies over de oorzaken van het hartinfarct. Capaciteitsgroep Med. Psychol., RU Limburg.

Appels, A. (1979A): A psychosocial model of the pathogenesis of coronary heart disease. Gedrag, 7, 6-21.

Appe1s, A., Haes, W. de en Schuurman, J. (1979): Een test ter meting van het "Coxonary Prone Behavioux pattern" Type A. Ned. T. v. Psychol., 34, 181-188.

Appels, A., Pool, J., Lubsen, K., Kazemier, M., Does, E. van der (1979A): Psychische prodromen van het hartinfarct. Ned. T. V. Psychol. 34, 213-223.

Arlow, J.A. (1945): Identiflcation mechanisms in coronary occlusion. Psychosom. Med., 7, 195-209.

Bainton, C.R. en Peterson, D.R. (1963): Deaths from coronary heart disease in persons fifty years of age and youngex. The New 
Engl. J. of Med., 269, 569-575.

Barendregt, J.T. (1954): Resultaten van een Rorschach onderzoek bij

20 vrouwen i ijdende aan galsteenkolieken. Ned. T. v. Psychol.,

9. $289-310$.

Barendregt, J.T. (1954A). De hypothese der psychosomatische speciflciteit getoetst aan de Rorschach-reacties van patienten 1ijdende ari asthna bronchiale. Diss. B. van Dobbenburgh, Amsterdam.

Barendregt, J.T. (1956): "Cross-validatie" van een toetsing van de hypothese dex psychosomatische specificiteit. Ned. T. W. Psychol. $9,1-9$.

Barendregt, J.T. (1958): Lijders an psychosomatische kwalen als sociad a angepaste neurotici. Ned. T. V. Geneesk., 102, 20442046.

Barendregt, $\mathbb{J} \cdot \mathrm{T}$. (1961): Research in psychodiagnostics. Mouton, Den Hag BIz. 122-137.

Barendregt, J.T. en Groen, J. (1953): Een statistische bewexking var het Rorschach materiaal van patiënten met colitis ulcerosa. Ned. T. V. Psycho1., B, 469-489.

Berendregt, I.T. en Cornelissen, R.L. (1955): Een vergelijkende studie van karakterbeschrijvingen opgesteld uit biografische anameses en uit de resultaten van het Rorschach-onderzoek. Ned. T. V. Geneesk., 99, 2717-2721.

Barendregt, J.T., Aris-Dijkstra, M., Diercks, I.M.J. en Wilde, G.J. S. (1958): De Rorschach-test als middel tot toetsing van de hypothese der psychosomatische specificiteit; een cross-validatie. Ned. T. v. Psychol., 13, 173-195.

Bastians, I. (1968): Psychoanalytical investigations on the psychic aspects of acute myocardial infarction. Psychoth. and Psychosom. 16, 202-209.

Bastians, J. (1973): De betekenis van het hysterieconcept voor de psychosomatiek. In: F.H. Olthuis e.a.: Psychosomatiek: het Groen-boek. Boom, Meppel.

Bastlaans, J. (1975): Psychotherapy in psychosomatic medicine. Estratto da "Therapy in psychosomatic medicine" a cura di F. Antonelli. Edizioni luigi Pozzi S.P.A., Roma.

Bastiaans, J. (1977): The implications of the specificity concept for the treatment of psychosomatic patients. Psychoth. and Psychosom. 28, 285-293. 
Bastiaans. J. en Groen J. (1954): Psychogenesis and Psyohotherapy of bronchial asthma. In: Modern trends in Psychosomatic Medicine. Butterworth and Co, London.

Berg-Larsen, R. (1970): A Psychodynamic Evaluation of patients with Myocardial. Infarction with regard to their future occupational and social adjustment. Psychoth. and Psychosom., 18, 294-298.

Brand, R.J., Rosemman, R.H., Scholtz, R.I. en Friedman, M. (1976): Multivariate Prediction of coronary heart disease in the western collaboxative Group study compared to the findings of the Framingham Study. Circulation, 53, 348-355.

Bremer, J.J.C.B. (1971): Het zjekenhuis, milieu voor velen. In: Buma, J.T. (1971): Mens en Milieu.

Bremer, J.J.C.B. (1972): De ziekenhuispatiënt. Mijmegen.

Brozek, J., Keys, A. en Blackburn, H. (1966): Personality differences between potential coronary and non-coronary subjects. An. New York Ac. of Sci., 134, axt. 2, 1057-1064.

Bruhn, J.G., Chandler, B. en Lynn, T.N. (1966): Social characteristics of patients with coronary heart disease. The An. J. of Med. Sci. $25,629-637$.

Bruhn, J.G., Chandler, B. en wolf, S. (1969): A psychological stidy of survivors and nonsurvivors of myocardial infarction. Psychosom. Med., 31, 8-19.

Bortner, R.W. en Rosemman, R.H. (1967): The measurement of pattern A behavior. J. of Chron. Dis., 20, 525-533.

Bortmex, R.W. (1969): A short rating scale as a potential measure of pattern A behavior. J. of Chron. Dis., 22, 87-91.

Bortner, R.W., Rosenman, R.H. en Friedman, M. (1970): Familial similarity in pattern $A$ behavior. J. of Chron. Dis., 23, 39-43.

Caffrey, B. (1966): Behavior patterns and personality charactexisw tics related to prevalence rates of coronary heart disease in Trappist and Benedictine Monks. Ann Arbor, Michigan: University Microfilms.

Caffrey, B. (1967): Interpersonal and psychologloal characteristics in cardiovascular disease: A review of empirical findings.

Milbarik mem. Fund. Q. Bull. $40(2), 119-140$.

Caffrey, B. (1968): Reliability and validity of personality and behavioral measures in a study of coronary heart disease. I. of chron. Dis., 21, 191-204. 
Caffrey, B. (1969): Behavior patterns and personality characteristics related to prevalence rates of coronary heart disease in American monks. J. of Chron. Dis., 22, 93-103.

Caffrey, B. (1970): A multivariate analysis of sociopsychological factors in monks with myocardial infarction. Am. J. Publ. Health, $60,452-458$.

Catte11, R.B., Saunders, D.R. en Stice, G. (1957): Handbook for the Sixteen Personality Factor questionnaire. The Institute for personality and ablitity testing. Champaign, Ill.

Cay, E.L., vetter, N., Philip, H.E. en Dugard, P. (1972): Psychological status auring recovery from an acute heart attack. J. of Psychosom. Res. , 16, 425-435.

Clyde, D.J. (1963): Manual for the Clyde Mood scale. University of Miami, Coral Gables, Fla.

Cleveland, S.E. en Johnson, D.L. (1962): Personality patterns in young males with coronary disease. Psychosom. Med., 24, 600610 .

Dahlstrom, W.G. en Welsh, G.S. (1960): An MMPI Handbook. University of Minnesota Press, Minneapolis.

Dreyfuss, F., Dasberg, H. en Assael, M.I. (1969): The relationship of myocardial infarction to depressive illness. Psychoth. and Psychosom., 17, 73-81.

Doornen, L.J.P. van (1979): Psychologische en psycho-fysiologische aspecten van het hartinfarct. Gedrag, $7,76-95$.

Dovenmuehle, R.H. en Verwoerdt, A. (1962): Physical illness and depressive symptomatology. Incidence of depressive symptoms in hospitalized cardiac patients. J. Am. Geront. Soc., 10, 932947.

Dunbar, Fl. (1948): Psychosomatic diagnosis. P.B. Hoebex, London, New York.

Dij1, H. van (1967): Test Behaviour differences between asthmatics and myocardial infarctions patients on a self-evaluation test. I. of Peychosom. Res., 11, 51-58.

Dijl, H. van (1973): ontwikkelingsfasen en enkele resultaten van.. psychologische test-onderzoekingen bij psychosomatische patienten. In: F.H. Olthuis e.a.: Psychosomatiek: Het Groen-boek. Boom, Meppel.

Dij1, H. Van (1975): Hartinfarctpatiënten, werkwaardering en beroepsverantwoordelijkheid. Een empirisch psychologisch onder- 
zoek. Huisarts en wetenschap, 18, 119-124.

Dijl, H. van (1975): Myocardial infarction patients and work attitudes. An empirical study. J. Psychosom. Res., 19, 197-202.

Dijl, H. van (1978): Hartinfarctpatienten en sociabilitelt. T. V. soc. Geneesk. , 56, 443-447.

Dijl, $H$. van (1978): The $A / B$ typology according to Friedman and Rosenman and an effort to test some of the characteristics by means of a psychological test (RSL or BUL). J. Psychosom. Res." $22,101-109$.

Dijl, H. van (1978A): De A/B-typologie volgens Friedman en Rosenman en een poging tot empirische toetsing van enkele van haar kenmerken met behulp van een psychologische test (BUI). (Belgisch) T. v. Geneesk., 18, 1165-1173.

Dij1, $H$. van (1979): Myocardial infarction patients and sociability. J. Psychosom. Res., 23, 3-6.

Dijl, H. van en olthuis, F.H. (1970): Some test behavioux differences between healthy men and male myocardial infarction patients. Psychoth. and Psychosom. : 18, 286-293.

Dijl, H. van en Nagelkerke, N.J.D. (1979): A statistical discrimination of male myocardial infarction patients and healthy males by means of a psychological test and a tracing of basic dimensions of the infarction pexsonality. Voordracht gehouden in 1979 te Maastricht in het kader van het symposium: The role of psychosocial factors in the pathogenesis of coronary heart disease.

Egeren, L.F. $\operatorname{van}(1979)$ : Social interactions, communication and the coronary-prone behavior pattern: A psychophysiological study. Psychosom. Med., 41. no $1,2-18$.

Elizur, A. (1949): content analysis of the Rorschach with regard to anxiety and hostility. Rorschach Res. Exch., 247.

Finn, Fr., Mulcahy, R. en O'Doherty, E.F. (1966): The psychological assessment of patients with coronary heart disease. Ir. I. Med. Sc. $489,399-404$.

Forssman, O. en Lindegard, B. (1958): The post-coronary patient. A multidisciplinary investigation of middle-aged swedish males. Psychosom. Med., 3, 89-169.

Friledman, M., Rosenman, R.H. en Byers, S.O. (1955) : Deranged cholesterol metabolism and its possible relationship to human atherosclerosis: a review. J. of Gerontol. 10, 60-85. 
Frledman, M. en Rosenman, R.H. (1957): Comparison of fat intake of Anerican Men and Women. Possible relationship to incidence of clinical coronary artery disease. Circulation, $16,339-347$.

Frledman, M. Rosenman, F.H. en Carroll, V. (1958): Changes in the serum cholesterol and blood clotting time in men subjected to cyclic variation of occupational stress. Circulation, 17, 852861 .

Friedman, M. en Rosenman, R.H. (1959): Association of specific overt behavior pattern with blood and cardiovascular findings. J.A.M.A., 169, 1286-1296.

Friedman, M. en Rosenman, R.H. (1960): Overt behavior patern in coronary alsease. Detection of overt behavior pattern $A$ in patients with coronary disease by a new psychophysiological procedure. J.A.M.A., 173, 1320-1325.

Friedman, M., St. George, S., Byers, S.O. en Rosenman, R.H. (1960): Excretion of catecholamines, 17-ketosteroids, 17-hydroxycorticoids and 5-hydroxyindole in men exhibiting a particular behavior pattern (A) associated with high incidence of clinical coronary artery disease. J. Clin. Investigation, 39, $758-764$.

Friedman, M., Rosenman, R.H. en Brown, A.E. (1963): The continuous heart rate in men exhibiting an overt behavior pattern associated with increased incidence of clinical coronary artery disease. Circulation, 28, $861-866$.

Friedman, M., Rosenman, R.H. en Byers, S.0. (1964): Serum 1ipids and conjunctival circulation after fat ingestion in men exhibiting Type-A behavior pattern. Circulation, 29, 874-886.

Friedman, M. (1964): Behavior pattern and its pathogenetic role in clinical coronary artery disease. Geriatrics, august, 562-567.

Friedman, M. Byers, S.0. en Rosenman, R.H. (1964A): Effect of corticotropin upon triglyceride levels. J.A.M.A., 190, 959-964.

Friedman, M. en Rosenman, R.H. (1966): Letters to the Editor. Psychosom. Med., 28, 282-283.

Frledman, M., Rosenman, R.H., Straus, R., Wurm, M. en kositchek, R. (1968): The relationship of behavior pattern A to the state of the coronary vasculature. A study of fifty-one autopsy subjects. Ain. J. Med., 44, 525-537.

Friedman, M. Rosenman, R.H. en St. George, S. (1969): Adrenal response to excess corticotropin in coronary-prone men. Proc. Soc. Exp. Biol. and Med., 131, 1305-1307. 
Friedman, M., Brown, A.E. en Rosenman, R.H. (1969A): Voice analysis test for detection of behavior pattern. Responses of normal men and coronary patients. J.A.M.A., 208, 828-836.

Friedman, M. en Elek, S.R. (1970): Pituitary growth hormone essential for regulation of serum cholesterol. Nature, $225,464-467$.

Friedman, M., Byers, S.O., Rosenman, R.H. en Elevitch, F.R. (1970): Coronary-prone individuals (Type A behavior pattem). Some biochemical characteristics. J.A.M.A., 212, 1030-1037.

Friedman, M. en Rosenman, R.H. (1971): Type A behavior pattern: Its association with coronary heart disease. Ann. Clinical Res., $3,300-312$.

Friedman, M. (1972): Hypercholesterolemic effects of human growth hormone in coronary prone (Type A) hypercholesterolemic subjects. Proc. Soc. Exp. Biol. and Med., 141, 76-80.

Friedman, M. "Manwaring, J.H., Rosenman, R.H. , Donlon, G., Ortega, P.en Grube, S.M. (1973): Instanteneous and sudden deaths. Clinical and pathological differentiation in coronary artery disease. J.A.M.A., 225, $1319-1328$.

Friedman, M. en Rosenman R.H. (1974): Type A behavior and your heart. A. Knopf. New York.

Eriedman, E.H., Hellerstein, H.K., Jones, S.E. en Eastwood, G.L. (1965): Behavior patterns and serum cholesterol in two groups of normal males. Paper read at Am. Heart Association Meeting. Miami, Florida.

Gentry, W.D. "Foster, S. en Haney, "T. (1972): Denial as a determinant of anxiety and pexceived health status in the coronary care unit. Psychosom. Med., 34, 39-44.

Gertler, M.M., Garn, S.M. en White, P.D. (1954): Coronary heart disease in young adults. Cambridge, Máss., Harvara.

Gildea, E.F. (1949): special features of personality which are common to certain psychosomatic aisorders. Psychosom. Mea., 11, $273-281$.

Gottschalk, I.A., Gleser, G.C. en Springer, K.J. (1963): Three hostility scales applicable to verbal samples. A.M.A. Arch. Gen. Psychiat., 9, 254 .

Gough, H.G. (1957): Manual for the California Psychological Inventory. Palo Alto, Consulting psychologists press.

Green, W.A., Goldstein, S. en Moss, A.J. (1972): Psychosocial aspects of sudden death. Arch. Intexn. Med., 129,725-731. 
Groen, J., Horst, L. Van der, Bastians, J., Valk, J.M. van der en vies, S.J. (1950): organisatie, werkterrein en enkele uitkomsten van de werkgroep voor psychosomatisch onderzoek in het wilhelmina Gasthuis te Ansterdam. N.T. v. Geneesk., 94, 2816-2833.

Groen, J. (1950): Asthma bronchjale seu nervosum. Scheltema en Holkema, Amstexdan.

Groen, J. Horst, L. van der en Bastiaans, J. (1951): Grondslagen dex klinische psychosomatiek. De Erven F. Bohn N.V. Haarlem.

Groen, J., Valk, J.M. wan der, Treurniet, N., Kits van Heyningen, H., Pelser, H.E. en Wilde, G.J.S. (1965): Het acute myocardinfarct; een psychosomatische studie. Exven F. Bohn, Haarlem.

Groen, J. en Valk, J.M. van der (1965): Persoonlijkheidsstructuur, conflictsituatles, en gedrag bilj lijders aan acuut myocardinfarct. In: Groen, $J$. en anderen (1965): Het acute myocardinfarct; een psychosomatische studie. Erven F. Bohn, Haarlem.

Groen, J. (1967): De invloed van etnische en psycho-sociale factoren in de pathogenese van atherosclerose en coronaire hartziekten en hun betekenis voor therapie en preventie. N. T. v. Geneesk., $111,1807-1820$.

Guilford, J.P. en Martin, H.G. (1943): The Guilford-Martin Personnel Inventory 1. Beverly Hills, Sheridan supply Co.

Guilford, J.P. en Martin, H.G. (1943B): The Guilford-Martin Inventory of factors GAMIN. Beverly Hills, Sheridan Supply Co.

Hathaway, S.R. en Mckinley, J.C. (1951): Minnesota Multiphasic Personality Inventory Manual. The Psychological Corp., New York.

Hermans, H.J.M. (1967): Motivatie en prestatie. Swets en Zeitlinger. Amsterdam.

Jenkins, C.D. (1966): Components of the coronary-prone behavior pattern. Their relation to silent myocardial infarction and blood 11plds. J. of Chron. Dis., 19, 599-609.

Jenkins, C.D., Rosenman, R.H. en Friledman, M. (1967): Development of an objective psychological test for the determination of the coronary-prone behavior pattern in employed men. J. of chron. Dis., $20,371-379$.

Jenkins, C.D., Rosenman, R.H. en Zyzanski, S.J. (1968A): Cigarette smoking. Its relationship to coronary heart disease and relate risk factors in the Western collaborative Group study. Circulation, $38,1140-1155$. 
Jenkins, C.D., Rosenman, R.H. en Friedman, M. (1968): Repldcability of rating the coronary-prone behaviour pattern. Brit. I. Prev. and Soc. Med., $22,16-22$.

Jenkins, C.D., Hames, C.G., Zyzanski, S.J., Rosenman, R.H. en Friedman, M. (1969): Psychological traits and serum ilpids. Psychosom. Med., 31, 115-128.

Jenkins, C.D. (1971): Psychological and social precursors of coronary disease. (First of two parts). The New Engl. I. of Med., $284,244-255$.

Jenkins, C.D. (1971): Psychological. and social precursors of coronary disease. ( Second of two parts). The New Engl. J. of Med., $284,307-317$.

Jenkins, C.D., Zyzanski, S.J., Rosenman, R.H. en Cleveland, G.L. (1971): Association of coronary-prone behavior scores with recurxence of coronary heart disease. J. of Chron. Dis., 24, 601611.

Jenkins, C.D., Zyzanski. S.J. en Rosenman, R.H. (1971): Progress toward validation of a computer-scored test for the rype A coronary-prone behavior pattern. Psychosom. Med., 33, 193-202.

Jenkins, C.D., Rosenman, R.H. en zyzanski., S.J. (1974): Prediction of clinical coronary heart disease by a test for the coronary prone behavior pattern. The New Engl. J. of Med., 290, 12711275 .

Jenkins, C.D. (1976): Recent evidence supporting psychologic and social risk factors for coronary disease. (First of two parts). The New Engl. J. of Med., 294, $987-994$.

Jenkins, C.D. (1976): Recent evidence supporting psychologic and social risk factors for coronary disease. (second of two parts). The New Engl. J. of Med., 294, 1033-1038.

Jenkins, C.D., Zyzanski, S.J. en Rosenman, R.H. (1976): Risk of new myocardial infarction in midale-aged men with manifest coronary heart disease. Circulation, $53,342-347$.

Jenkins, C.D., Zyzanski., S.J., Ryan, T.J., Flessas, A. en pannenbaum, S.I. (1977): Social insecurity and coronary-prone Type $A$ responses as identifiers of severe atherosilerosis. I. of Consult. and Clin. Psychol. 45, 1060-1067.

Jenkins, C.D., Zyzanski, S.J. en Rosenman, R.H. (1978): Coronaryprone behavior: one pattern or several? Psychosom. Med., 40 , $25-43$. 
Joreskog, K.G. (1963): Statistical estimation in Factor Analysis. Stockholm.

Kasanen, A., Kallio, V. en Forsström, J. (1963): The significance of psychic and socio-economic stress and other modes of life in the etiology of myocardial infarction. Ann. Med. internae Fenriae, 52, suppl. $43,5-40$.

Keith, R.A., Lown, B. en Stare, F. (1965): Coronary heart disease and behavior patterns. An examination of method. Psychosom. Med. $27,424-434$.

Kemple, C. (1945): Rorschach method and psychosomatic diagnosis. Psychosom. Med., 7, 85-89.

Kenigsberg, D., zyzanski, S.J., Jenkins, C.D., Wardwell, W.I. en I.icciarde110, A.T. (1974): The coronary-prone behavior pattern in hospitalized patients with and without coronary heart disease. Psychosom. Med. , 36, 344-351.

Kesse1, N. en Munro, A. (1964): Epidemiological studies in psychosomatic medicine. J. of Psychosom. Res., 8, 67-81.

Kits var Heyningen, H. (1960): Some notes on the psychiatric aspects of patients with coronary occlusions. Advances in Psychosom. Med., 1, 294.

Kits Van Heyningen, $\mathbb{H}$. (1965): De stress-situatie voorafgaande aan het ontstaan van het myocardinfarct. In: Groen, J. e.a. (1965).

Klein, H.P. en Parsons, O.A. (1968): Self-descriptions of patients with coronary disease. Perc. and Motor skills, 26, $1099-1107$.

Lebovits, B.z., Shekelle, R.B., Ostfeld, A.M. en Paul, O. (1967): Prospective and retrospective psychological studies of coronary heart disease. Psychosom. Med., 29, 265-272.

Liljefors, I. en Rahe, Car.R.H. (1970): An identical twin study of psychosocial factors in coronary heart aisease in sweden. Psychoson. Med., 32, 523-537.

Ijind, E. en Theore11, T. (1973): Sociological charactexistics and myocardial infarctions. J. of Psychosom. Res., 17, 59-73.

Mcclelland, C.D. (1961): The achieving society. Van Nostrand, New York.

Miles, H.H.W., Waldfoge1, S., Barrabee, E.L. en Cobb, S. (1954): Psychosomatic study of 46 young men with coronary artery disease. Psychosom. Med., 16, 455-477.

Miller, C.K. (1965): Psychological correlates of coronary artery disease. Psychosom. Med., 27, 257-265. 
Mordkoff, A.M. en Rand, M.A. (1968): Personality and adaption to coronary artery disease. J. of Consult. and Clin. Psychol., 32, 648-653.

Nass, C., Verhagen, F. en Winnubst, J.A.M. (1979): A/B typologie, de Protestantse Ethiek en het Westerse Tijdssyndroom. Een empirische studie. Gedrag, $7,41-57$.

Olthuis, F.H. (1972): Extreme Response style en Faktoren. Testgedrag van hattinfarctpatienten vergeleken met gezonden en nietgezonden. Skriptie-werkstuk. Psychologisch Laboratorium, G.U., Ansterdam.

olthuis, F.H. en anderen (1973): Psychosonatiek: het Groen-boek. Boom. Meppel.

Osler, Sir W. (1897): Lectures on Angina Pectoris and Allied States. Appleton-Century. New York.

Ostfeld, A.M., Lebovits, B.Z., Shekelle, R.B. en Paul, O. (1964): A prospective study of the relationship between personality and coronary heart disease. J. of Chron. Dis., 17, 265-276.

Price, K.P. en Clarke, L.K. (1978): Behavioral and psychophysiological correlates of the coronary-prone personality: new data and unanswered questions. J. of Psychosom. Res., 22, 409-417.

Quinlan, C.B. en Barrow, J.G. (1966): Prevalence of coronary heart disease in Trappist and Benedictine monks. Circulation, Suppl. TII to Vols. 33 en 34 .

Rooymans, H.G.M. (1974): Het begrip "specificitelt' in de psychosomatische geneeskunde. Ned. T. V. Geneesk., 11, 121-127.

Rosen, J.L. en Bibring, G.L. (1966): Psychosocial reactions of hospitalized male patients to a heart attack. Psychosom. Med." $28.808-821$.

Rosenman, R.H. en Friedman, M. (1961): Association of specific behavior pattern in women with blood and cardiovascular findings. Circulation, $24,1173-1184$.

Rosenman, R.H. en Friedman, M. (1962): The role of a specific overt behavior pattern in the occurence of ischemic heart disease. Cardiologia pratica, 13,42-53.

Rosenman, R.H. en Friedman, M. (1963): Beliavior patterns, blood lipids and coronary heart disease. J.A.M.A., 184, 934-938.

Rosenman, R.H. Friedman, M., Straus, R., Wurm, M., Kositchek, R. Hahn, W. en Werthessen, N.T. (1964): A predictive study of coronary heart aisease. J.A.M.A., 189, 15-22. 
Rosenman, R.H., Friedman, M. Jenkins, C.D., Straus, R., Wurm, M. en Kositchek, R. (1966): The prediction of immunity to coronary heart aisease. J.A.M.A., 198, 1159-1162.

Rosenman, R.H. Friedman, M. "Straus, R., Wurm, M., Jenkins,C.D. en Messinger, H.B. (1966A): Cononary heart disease in the Western collaborative Group study. A follow-up experience of two years. J.A.M.A., 195, 130-136.

Rosenman, R.H. "Eriedman, M. Jenkins, C.D., Straus, R., Wurm, M. en kositchek, R. (1967): Recurring and fatal myocardial infarction in the western collaborative Group Study. Am. J. of Cardiol., 19,771-775.

Rosenman, R.H., Friedman, M. , Jenkins, C.D., Straus, R., Wurm, M. en Kositchek, R. (1967A): Clinically unrecognized myocardial infarction in the Western Collaborative Group Study. An. J. of Cardiol., 19, 776-782.

Rosenman, R.H., Friedman, M., Jenkins, C.D. en Bortner, R.W. (1968): Is there a coronary-prone personality? Int. J. Psychiatry, 5, $427-433$.

Rosenman, R.H. "Frledman, M., Straus, R., Jenkins, C.D., Zyzanski, S.J. en Wurm, M. (1970): Coronary heart disease in the western Collaborative Group study. A follow-up experience of $4 \frac{1}{5}$ years. J. of Chron. Dis., 23, 173-190.

Rosenman, R.H. (1971): Assessing the risk associated with behavior patterns. J. Med. Ass. Georgia, 60, 31-34.

Rosenman, R.H., Brand, R.J., Jenkins, C.D. ,Friedman, M., Straus, $\mathbb{R}$. Wurm, M. (1975): Coronary heart disease in the western Collaborative Group study. Final follow-up experience of $8 \frac{1}{2}$ years. J.A.M.A., 233 , 872-877.

Rosenman, R.H., Friedman, M. (1977): Modifying Type A behaviour pattern. J. Psychosom. Res., 21, 323-331.

Rosemman, R.H. en Chesney M.A. (1980): The relationship of Type A behavior pattern to coronary heart disease. Activ. nerv. sup. (Praag), 22, 1-44.

Russek, H. L. en Zohman, B.L. (1958): Relative significance of heredity, diet and occupational stress in coronary heart disease of young adults. Am. J. Med. Sci., 235, 266-277.

Schucker, B. en Jacobs, D.R. (1977): Assessment of behavioral risk for coronary dilsease by voice characteristics. Psychosom. Med. $39,219-228$. 
Scherwitz, L. Beron, K. en Leventhal, H. (1977): rype A assessment and interaction in the behavior pattern interview. Psychosom. Med. 39, 229-240.

Scherwitz, L., Beron, K. en Leventhal, H. (1978): Type A behavior, Selfinvolvement and cardiovascular response. Psychoson. Med., $40,593-609$.

Shekelle, R.B. en Ostfeld, A.M. (1965): Psychosomatic evaluations in cardiovascular epidemiology. An. New York Ac. of Sci., 126, 696-705.

Siegel, S. (1956): Nonparametric statistics for the behavioural. sciences. Mc Grawhil1, New York.

Siltanen, P., Lauroma, M., Nirkko, O., Punsar, S., Pyörlala, K., "Tuominen, H. en Vanhala, K. (1975): Psychological characteris" tics related to coronary heart disease. J. of Psychosom. Res., 19. $183-195$.

Storment, Ch.T. (1951): Personality and heart-disease. Psychosom. Med. , 13, 303-313.

Theore11, T. en Rahe, R.H. (1972): Behaviox and life satisfaction characteristics of swedish subjects with myocardial infarction. J. of Chron. Dis., 25, 139-147.

Thiel, H.G., Parker, D. en Bruce, T.A. (1973): Stress factors and the risk of myocardial infarction. J. of Psychosom. Res., 17 , $43-57$.

Thurstone, L. (1950): Thurstone Temperament Schedule. Soc. Sci. Res. Ass., Chicago, Ill.

Treurniet, N. (1965): De persoonlijkheidsstructur bij patienten met myocardinfarct. In: Groen, J. e.a. 1965.

Valk, J.M. Van der (1960) : Comparison of the social setting and bohavior of patients with bronchial asthma, coronary occlusions and healthy subjects. Advances in Psychosomatic Med., I. Separatum vol. 1.

Valk, J.M. van der en Groen, J.J. (1967): personality structuxe and conflict situation of patients with myocardial infarction. J. of Psychosom. Res., $11,165-183$.

Vles, s.J. en Groen, J.J. (1951): Een ondexzoek van de persoonlijkheidsstructur bij jeugdige asthmapatienten met behulp van de Behn-Rorschach-proef. N. T. v. Psychol., 6, 29-40.

Vles, S.J. en Groen, J. (1952): Resultaten van een psychologisch onderzoek van een aantal volwassen asthmapatienten met behulp 
van de Behn-Rorschach-proer. N. T. V. Psychol., 7, 464-482.

Wardwe11, W.I., Hyman, M. en Bahnson, C.B. (1968): socio- enviromental antecedents to coronary heart disease in 87 white males. Soc. Scl. and Med., 2, 165-183.

Wechsler, D. (1958): The measurement and appraisal of adult intelligence. Williams and Wilkins, Ballimore.

Weiss, E., DLin, B., Rollin, H.R., Fischer, H.K. en Bepler, C.R. (1957): Emotional factors in coronary occlusion. A.M.A. Arch. of internal Med. , 99, 628-641.

welsh, G.S. en Dahlstrom, W.G. (eds) (1956): Basic readings on the MMPI in psychology and medicine. University of Minnesota Press, Mirneapolis.

Wilde, G.J.S. (1960): De Vier Platen Test van van Lennep als middel tot toetsing van de hypothese der psychosomatische specificiteit. Ned. T. V. Psychol., 15, 145-157.

Wilde, G.J.S. (1962, vermeexderde druk 1970): Neurotische labilitelt gemeten volgens de vragenlijstmethode. van Rossen, Amsterdam.

Wilde, G.J.S. en Barendregt, J.T. (1957): Toetsing van de hypothese der psychosomatische specificiteit met behulp van de Vier Platen Test van van Lennep. Med. T. v. Psychol., 12, 38-48.

Winnubst, J.A.M. (1975): Het Westerse Tijdssyndroom, diss. Swets en zeitlinger. Amsterdam.

Zung, W.W.K. (1965): A self-rating depression scale. Arch. Gen. Psychiat. $12,63-70$.

Zyzanski, S.J. en Jenkins, C.D. (1970): Basjc dimensions within the coronary-prone behavior pattern. I. of Chron. Dis., 22, 781795 . 


\section{CURRICULUM VITAE.}

De schrijver van deze dissertatie werd op 25 februari 1936 te Amsterdam geboren. De laatste vijf klassen van het lager onderwjjs doorliep hij in Amersfoort. Van 1948 - 1953 bezocht hij aldaar de MuLo, warna hij gedurende 2 jaar het Baarns Lyceum bezocht en in 1955 het diploma HBS-A behalde. Na de militaire dienst vervuld te hebben begon hij in 1956 de studie psychologie aan de Rijksuniversiteit te Utrecht, alwar hij in 1964 het doktoraal examen psychologie. met als hoofarichting klinische psychologie, behaalde.

vanaf 1964 is hij tot op heden als psychologisch medewerkex verbonden aan de Psychosomatische werkgraep van het wilhelmima Gasthus te Amsterdam. Naast het onderzoeksgebied betreffende de hypothese der psychosomatische specificiteit en het speciale deelgebied daarvan warop dit proefschrift betrekking heeft, richtten zijn werkzaamheden zich in onderzoek en praktijk op gedragstherapie, hypnose, co-counseling in selE-help groepen en het meest recent op de bioenergetische analyse.

Tot recent was de schrijver voorzitter van de werkgroep "Psychosociale determinanten van het hartinfarct" "die in februari 1978 haar eerste bijeenkomst hield. 